JOSÉ LUIS AVANZO

Carcinogênese pulmonar em camundongos portadores de deleção em um dos alelos do gene da $\mathrm{Cx} 43$ 
JOSÉ LUIS AVANZO

\section{Carcinogênese pulmonar em camundongos portadores de deleção em um dos alelos do gene da Cx43}

Tese apresentada ao Programa de Pósgraduação em Patologia Experimental e Comparada da Faculdade de Medicina Veterinária e Zootecnia da Universidade de São Paulo para obtenção do título de Doutor em Ciências

Departamento:

Patologia

Área de concentração:

Patologia Experimental e Comparada

Orientador:

Profa. Dra. Maria Lúcia Zaidan Dagli

São Paulo

2005 
Autorizo a reprodução parcial ou total desta obra, para fins acadêmicos, desde que citada a fonte.

DADOS INTERNACIONAIS DE CATALOGAÇÃO-NA-PUBLICAÇÃO

(Biblioteca da Faculdade de Medicina Veterinária e Zootecnia da Universidade de São Paulo)

\section{T. 1469 Avanzo, José Luis}

FMVZ Carcinogênese pulmonar em camundongos portadores de deleção em um dos alelos do gene da Cx43 / José Luis Avanzo São Paulo : J. L. Avanzo, 2005.

303 f. : il.

Tese (doutorado) - Universidade de São Paulo. Faculdade de Medicina Veterinária e Zootecnia. Departamento de Patologia, 2005.

Programa de Pós-graduação: Patologia Experimental e Comparada.

Área de concentração: Patologia Experimental e Comparada.

Orientador: Profa. Dra. Maria Lúcia Zaidan Dagli.

1. Conexina. 2. Uretana. 3. Carcinogênese animal. 4. Pulmão. 5. Interação celular. I. Título. 


\title{
CERTIFICADO
}

\author{
Certificamos que o Projeto intitulado
}

"Carcinogênese pulmonar em camundongos portadores de deleção em um dos aleleos da conexina 43 (Cx $43+/-)^{\prime \prime}$, Protocolo n 58/2002, sob a responsabilidade da Prof'Dr' Maria Lúcia Zaidan Dagli, está de acordo com os princípios éticos de experimentação animal da Comissăo de Bioética da Faculdade de Medicina Veterinária e Zootecnia da Universidade de São Paulo e foi aprovado pela referida Comissằ, em sessão de 17/04/ 2002.

(We certify that the Research "Lung carcinogenesis in Cx43 deficient mice" protocol number 58/2002, under the responsability of Prof Dr" Maria Lúcia Zaidan Dagli, agree with Ethical Principles in Animal Research adopted by Bioethic Commission of the Faculty of Veterinary Medicine and Zootechny of University of São Paulo and was approved in $04 / 17 / 2002$ meeting.

São Paulo, 17 de abril de 2002

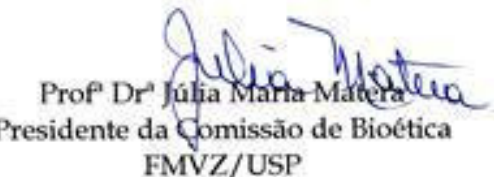




\section{FOLHA DE AVALIAÇÃO}

Nome do autor: Avanzo, José Luis

Título: Carcinogênese pulomnar em camundongos portadores de deleção em um dos alelos do gene da Cx43

Tese apresentada ao Programa de Pósgraduação em Patologia Experimental e Comparada da Faculdade de Medicina Veterinária e Zootecnia da Universidade de São Paulo para obtenção do título de Doutor em Ciências

Data:

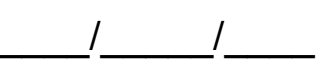

\section{Banca Examinadora}

Prof. Dr.

Assinatura:

Prof. Dr.

Assinatura:

Prof. Dr.

Assinatura:
Instituição:

Julgamento:

Instituição:

Julgamento:

Instituição:

Julgamento: 
À minha Mãe

e em memória

de meu Pai. 
Esta tese teve o apoio financeiro da:

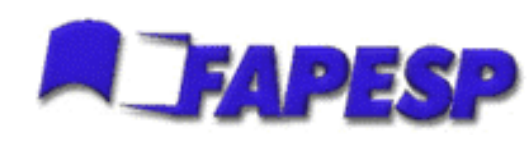

Fundação de Amparo à Pesquisa do Estado de São Paulo Processo 01/06821-9 Auxílio à Pesquisa 01/06820-2 
Esta tese teve o apoio financeiro da:

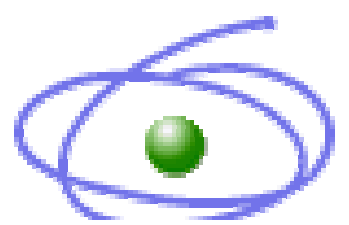

CAPES

Coordenação de Aperfeıçoamento de Pessoal de Nível Superior

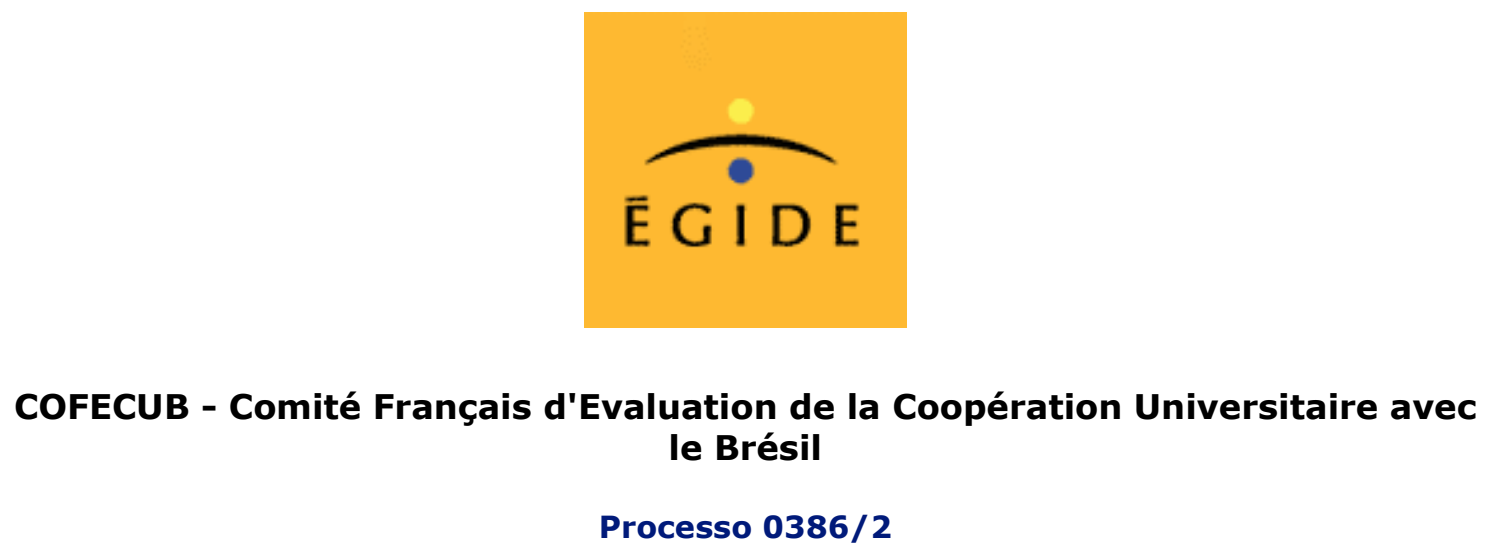




\section{AGRADECIMENTOS}

omeçar ou terminar esta tese não teria sido possível sem a extrema consideração, paciência, e bom humor por parte de minha orientadora Maria Lúcia Zaidan Dagli. Ela tornou mais fáceis meus momentos e fez do dela os mais difíceis; e é por isso que eu deixo em troca os meus mais profundos agradecimentos.

Eu gostaria também de agradecer as muitas pessoas com quem, por algum instante, compartilhei minhas dúvidas. Eu sou especialmente grato ao Prof. Dr. Francisco Javier Hernadez Blazquez, que me permitiu trilhar meus primeiros passos na carreira científica. Agradeço ao Prof. Dr. Rogério Lacaz-Ruiz por ter me apoiado em todas minhas decisões. Agradeço ao Prof. Dr. Marcelo de Cerqueira César, por ter me ensinado a seriedade de um verdadeiro pesquisador. Não tenho palavras para agradecer o Prof. Dr. Marc Mesnil que me acolheu com toda consideração e respeito, além de compartilhar toda sua sabedoria e aizade.

Pelos bons momentos, companheirismo, colaboração ou apenas um bom dia, gostaria de agradecer o Heidge, Tereza, Ivone, Lucas, Aninha, Deus, Marcelo, Cíntia, Luciana, Silvia, Stefani, Patrícia, Renata, Carol, Kátia Pinnelo, Kátia Kimura, Márcia, Dona Romêica, Viviane Néri, Viviane Platzer, Paulinha, Afrodite, Sheila, Meyre, Emerson, Priscila, Tatiane, Emelie, Wanderlei, Hudson, Gilvan, Tarso. Aos meus companheiros da Universidade de Poitiers Laurant, Malassinez, Isabelle, Gregory, corine, Fabein, Françoise. Chantal, Brunno, Jean-Claude, Marie, Amelie.

Seria impossível ter feito qualquer coisa sem a contribuição da D. Vilma, Herland, Cláudio, Luciano, Cláudia, Silvia, Seu Luis, Nelsinho, Rosíres, Idalina, Guerra, Idércio, Shirley, Bete, Marcinha, Belzinha, Elza e Ana da biblioteca, Ana Helena (UNIFIAN), Wellington, D. Tereza, SE.

Agradeço à minha noiva Rafaela Pinheiro e sua família.

Se me esqueci de você que está lendo este exemplar, minhas mais sinceras desculpas e considere-se como parte dos belos momentos vivenciados por mim durante esta etapa de minha vida. 


\section{RESUMO}

AVANZO, J. L. Carcinogênese pulmonar em camundongos portadores de deleção em um dos alelos do gene da Cx43. [Lung carcinogenesis in mice with a deletion in one allele of Cx43 gene]. 2005. 303 f. Tese (Doutorado em Ciências) - Faculdade de Medicina Veterinária e Zootecnia, Universidade de São Paulo, São Paulo, 2005.

As junções comunicantes são canais protéicos formados entre células adjacentes que permitem a passagem de moléculas e íons menores do que $1 \mathrm{kDa}$; conexinas são proteínas que formam estas junções. Vêm sendo demonstradas na literatura a diminuição da capacidade de comunicação celular e alterações na expressão e/ou localização das conexinas em neoplasias. Este estudo foi realizado com o intuito de se verificar a influência da deleção de um dos alelos da Cx43 na carcinogênese pulmonar. Para tanto, camundongos geneticamente manipulados heterozigotos $\left(\mathrm{Cx} 43^{+/-}\right)$ou selvagens $\left(\mathrm{C} \times 43^{+/+}\right)$ de ambos os sexos receberam $3 \mathrm{~g} / \mathrm{kg}$ de uretana aos 15 e 17 dias de idade, e foram sacrificados após 25 semanas. As quantificações macro e microscópicas das lesões revelaram que os camundongos $\mathrm{Cx}_{4} 3^{+/-}$apresentaram maior multiplicidade de adenomas pulmonares. Estes apresentavam também maior taxa de proliferação celular, avaliada pela quantificação de núcleos positivos para o PCNA. As expressões das Cxs 26, 32, 43 e 46, presentes no epitélio pulmonar, foram avaliadas por PCR em tempo real (RT-PCR) e por imunoistoquímica. A expressão da Cx43 revelou-se cerca de 50\% menor em camundongos $\mathrm{C} \times 43^{+/-}$quando comparada à dos correspondentes $\mathrm{C} \times 43^{+/+}$, como esperado. Estudos in vitro mostraram que os pneumócitos de tipo II (APTII) extraídos de camundongos $\mathrm{Cx} 43^{+/-}$, apresentaram capacidade de comunicação menor do que os APTII de camundongos $\mathrm{C} \times 43^{+/+}$. Quando submetidos ao tratamento com uretana, a expressão de Cx 43 aumentou em 100\% no tecido pulmonar. As demais Cxs tiveram a expressão reduzida pelo tratamento e não foram evidenciadas no epitélio pulmonar livre de lesões após o tratamento com uretana. Não foi detectada a expressão da Cx43 e da Cx32 nos adenomas provenientes dos camundongos $\mathrm{Cx} 43^{+/-}$. A expressão das Cxs 26 e 46 foi correlacionada com o fenótipo papilífero das lesões. Constatou-se que a Cx32 acumulava-se no citoplasma das células epiteliais pulmonares e teve sua expressão, juntamente com a da $\mathrm{Cx} 43$, associada ao sexo, provavelmente contribuindo para a menor susceptibilidade das fêmeas aos adenomas induzidos pela uretana. Em conclusão, a redução da expressão da Cx43 conferiu maior susceptibilidade ao desenvolvimento de 
adenomas pulmonares pela uretana. Este foi o primeiro estudo in vivo mostrando a influência da deleção de um único alelo da Cx43 na carcinogênese.

Palavras-chave: Conexina. Uretana. Carcinogênese Animal. Pulmão. Interação Celular. 


\begin{abstract}
AVANZO, J. L. Lung carcinogenesis in mice with a deletion in one allele of Cx43 gene. [Carcinogênese pulmonar em camundongos portadores de deleção em um dos alelos do gene da Cx43]. 2005. 303 f. Tese (Doutorado em Ciências) Faculdade de Medicina Veterinária e Zootecnia, Universidade de São Paulo, São Paulo, 2005.

Gap junctions are communicating protein channels formed between adjacent cells that allow the exchange of molecules and ions smaller than $1 \mathrm{kDa}$; connexins are proteins that form these junctions. Studies in the literature have been showing the lower level of cell communication capacity and alterations in the expression and/or localization of connexins in neoplasia. This study was performed to verify the influence of the deletion of one allele of $\mathrm{C} x 43$ on lung carcinogenesis. Genetically manipulated heterozygous $\left(\mathrm{C} \times 43^{+/-}\right)$or wild

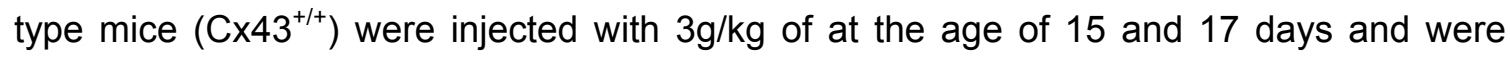
euthanized after 25-weeks. Macroscopic and microscopic quantification of pulmonary lesions revealed that $\mathrm{C} \times 43^{+/-}$mice presented higher multiplicity of pulmonary adenomas. These presented also a higher cell proliferation index, as evaluated by counting PCNA positive nuclei. Cxs 26, 32, 43 and 46 expressions in the pulmonary epithelium were investigated by Real-Time PCR and by immunohistochemistry. Cx43 expression was about $50 \%$ lower in $\mathrm{C} \times 43^{+/}$mice, in comparison to $\mathrm{C} \times 43^{+/+}$mice, as expected. In vitro studies showed that the APTII cells extracted from $\mathrm{Cx} 43+/-$ mice presented a reduced communication capacity. When treated with urethane, the expression of Cx43 was increased by $100 \%$. Other Cxs were down-regulated after the treatment with urethane, and were not observed lung areas devoid of adenomas after the treatment with urethane. $\mathrm{Cx} 43$ and $\mathrm{C} \times 32$ were not detected in $\mathrm{C} \times 43^{+/-}$mouse adenomas. However, Cx26 and Cx46 were correlated with papillary lesions. Cx32 was cumulated in the cytoplasm of the lung epithelial cells and its expression, together $\mathrm{Cx} 43$, were associated with the sex, maybe contributing to the lower susceptibility of the female mice to urethane. In conclusion, the reduced expression of $\mathrm{C} x 43$ determines a higher susceptibility to the development of pulmonary adenomas by urethane. This study was the first in vivo showing the influence of the deletion of one allele of $\mathrm{Cx} 43$ in carcinogenesis.
\end{abstract}

Key-words: Connexin. Urethane. Animal Carcinogenesis. Lung. Cell Interaction. 


\section{TERMOS EM INGLÊS}

Na literatura científica existem termos em inglês que já estão de tal maneira consagrados e conhecidos que perderiam seu sentido se fossem traduzidos para o português. Em nosso trabalho, optamos por manter esses termos em sua forma original. São eles:

Assays by design = pacote de serviço fornecido pela Applied Biosystems em que o pesquisador envia sua seqüência de interesse identificando apenas o local onde deve ser desenhado a probe fluorescente utilizada no PCR em tempo real.

Background = constituição genética .

Bystander effect = capacidade de se fazer passar substâncias tóxicas através das junções comunicantes do tipo gap com a finalidade de matar a célula tumoral.

cDNA = fita de ácido desoxirribonucléico complementar a ácido ribonucléico que contém a mensagem que codifica para determinada proteína.

Custom primers $=$ serviço fornecido pela Applied Biosystems onde 0 pesquisador envia o primer e a probe previamente desenhados por ele mesmo para que sejam sintetizados.

Cycle threshold $=$ ponto no qual se compara o nível de expressão dos genes no PCR em tempo real.

DNA = ácido desoxirribonucléico

Foward = primer que é lido pela Taq polimerase no sentido 5'-3' da fita de DNA senso.

Gap = fenda

Gating $=$ fechamento do poro formado pelas conexinas.

GenBank = banco de dados públicos onde estão contidos as seqüências genômicas de várias espécies.

GJIC = comunicação intercelular através de junções do tipo gap 
Immunoblot = identificação das proteínas por anticorpos específicos após eletroforese e transferência para membrana.

Knockout $=$ animais geneticamente manipulados em que determinado(s) gene(s) é (são) anulado(s) por vários métodos.

Loops = alças da molécula de DNA ou no caso das conexinas, se refere às alças extras e intracelulares que se dobram conectando cada domínio transmembrana.

mRNA = ácido ribonucléico cuja informação que codifica para uma determinada proteína estão contidos.

Overnight $=$ período de tempo correspondente há uma noite.

PCR = reação de polimerização em cadeia.

Primer = É uma seqüência de geralmente 20 bp que é ponto inicial de reconhecimento pela polimerase na duplicação do DNA senso.

Probe $=$ nome dado a seqüências de oligonucleotídeos (20 bp) que contém os fluoróforos utilizados no PCR em tempo real. O produto de amplificação do PCR em tempo real é proporcional à intensidade luminosa do fluoróforo.

Quencher = molécula utilizada na confecção das sondas fluorescentes utilizadas no PCR em tempo real com a finalidade de capturar a luz emitida pelo reporter.

Reporter $=$ molécula fluorescente utilizada na confecção das sondas utilizadas no PCR em tempo real.

Reverse $=$ primer que é lido Taq polimerase no sentido 5'-3' da fita de DNA anti-senso, mas que na fita senso seria lido no sentido 3'-5'.

RNA = ácido ribonucléico.

RT-PCR = reação de polimerização em cadeia a partir de RNA, utilizando a enzima transcriptase reversa.

Scrape-loading = técnica utilizada no estudo de junções comunicantes do tipo gap para se avaliar a eficiência de comunicação entre as células adjacentes.

Splicing = união dos éxons do pré-mRNA e exclusão dos íntrons originando o mRNA maduro. 
Spots = mancha de DNA corado pelo brometo de etídeo visualizada na luz ultravioleta.

Taqman = nome dado ao conjunto de primers e probe fluorescente utilizados no PCR em tempo real.

Western blot $=$ método para identificação de proteínas, baseado em extração, eletrofoese, transferência e identificação através de anticorpos e sistema de revelação.

Wild-type $=$ gene normal, presente no genoma de determinada espécie, é o camundongo selvagem. 


\section{SUMÁRIO}

2.1 CONHECIMENTO ATUAL SOBRE AS JUNÇÕES DO TIPO GAP E SITUAÇÃO DO TEMA DE PESQUISA.

2.1.1 Organização molecular das junções comunicantes do tipo gap......

2.2 AS PROTEÍNAS QUE COMPÕEM AS JUNÇÕES DO TIPO GAP: AS CONEXINAS

2.2.1 Uma família de genes

2.2.2 Uma família de proteínas.

2.2.3 Organização estrutural das conexinas.

2.3 DIVERSIDADE DAS CONEXINAS

2.3.1 Distribuição tecidual das conexinas.

2.3.2 Regulação da expressão dos genes das conexinas.

2.4 O CANAL JUNCIONAL PROPRIAMENTE DITO

2.4.1 Estrutura do canal juncional.

2.4.2 Montagem dos conexons

2.5 DINÂMICA DE FORMAÇÃO E DEGRADAÇÃO DAS PLACAS JUNCIONAIS.

2.5.1 Biosíntese das Cxs e montagem das junções gap..

2.5.2 Degradação das conexinas. 
2.6.1 Propriedades dos canais juncionais.

2.6.1.1 Definição da permeabilidade juncional.

2.6.1.2 Noção de permeabilidade seletiva.

2.7 MODULAÇÃO DA MONTAGEM DOS CANAIS INTERCELULARES.....

2.8 IMPLICAÇÕES FISIOLÓGICAS DAS JUNÇÕES DO TIPO GAP

2.8.1 Da difusão de moléculas à harmonização das funções fisiológicas

2.8.2 Funções das JG deduzidas de estudos de doenças genéticas e do fenótipo de camundongos knockouts para uma determinada conexina

2.8.2.1 Doenças genéticas humanas provocadas por mutações em genes de Cx.

2.8.2.2 Estudos dos fenótipos de camundongos knockouts para um gene da conexina.

2.8.2.3 O camundongo $\mathrm{C} \times 43^{-1-}$

2.9 CONTROLE DA PROLIFERAÇÃO CELULAR E DA DIFERENCIAÇÃO CELULAR PELAS JUNÇÕES DO TIPO GAP.

2.9.1 GJIC e carcinogênese.

2.9.2 Função das $\mathrm{Cx}$ no controle da proliferação e da diferenciação celular.

2.10 SITUAÇÃO DO ASSUNTO DE PESQUISA.

2.10.1 O epitélio pulmonar.

2.11 CARCINOGÊNESE INDUZIDA PELA URETANA.

2.12 CX43: A PRINCIPAL CONEXINA EXPRESSA NO TECIDO PULMONAR. 
3.1 OBJETIVO GERAL............................................................ 109

OBJETIVOS ESPECÍFICOS............................................................. 109

$4 \quad$ MATERIAL E MÉTODOS............................................................... 110

4.1 ESTUDOS IN VIVO REALIZADOS NA FMVZ-USP............................. 110

4.1.1 Camundongos.......................................................................... 110

4.1.1.1 Identificação dos animais............................................................... 111

4.1.2 Genotipagem dos camundongos................................................... 111

4.1.2.1 Extração de DNA da cauda dos camundongos.................................... 111

4.1.2.2 As condições de amplificação dos produtos de PCR ............................. 113

4.1.3 Modelo de carcinogênese pulmonar................................................. 114

4.1.3.1 Quantificação das lesões pulmonares em cortes histológicos de pulmão.

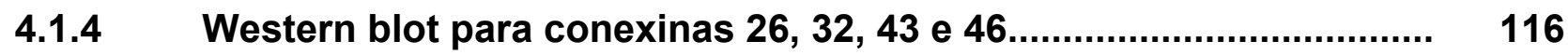

4.1.4.1 Principio da técnica.................................................................. 116

4.1.5 Reação da Polimerase em Cadeia registrada em tempo real (Real Time PCR).

4.1.5.1 Extração RNA Total pelo método do Trizol.......................................... 119

4.1.5.2 Quantificação RNA total.................................................................. 120

4.1.5.3 Tratamento do RNA total com DNAse I............................................. 120

4.1.5.4 Transcrição Reversa........................................................................ 121

4.1.5.5 PCR em tempo real no ABIPrism ${ }^{\circledR} 7000$ Sequence Detection Systems (Applied Biosystems)................................................ 122

4.1.5.6 Primers e probes................................................................... 125 
4.1.5.7 Condições da reação de Real Time PCR.

4.1.5.8 Interpretação dos resultados obtidos no sistema de Real time PCR......

4.1.5.8.1 Método comparativo do $2^{-\Delta \Delta C t}$ para a quantificação relativa (Livak \& Schimittigen, 2001)

4.1.5.8.2 Derivação da fórmula.

4.1.6 Imunomarcação para as conexinas $26,32,43$ e 46 nos tecidos fixados.

4.1.7 Detecção por PCNA das células em fase $S_{1}$ do ciclo celular nos diferentes tipos celulares

4.1.8 Análise estatística.

4.2 ESTUDOS IN VITRO - ETAPA REALIZADA NA UNIVERSIDADE DE POITIERS/FRANÇA, NO LABORATÓRIO DE BIOMEMBRANAS E SINALIZAÇÃO CELULAR.

4.2.1 Breve descrição da metodologia da extração dos Pneumocitos do Tipo II (APTII)...

4.2.2 Extração dos APTII

4.2.2.1 Preparação da placa com IgG $500 \mu \mathrm{g} / \mathrm{ml}$.

4.2.2.2 Preparação do colágeno a ser adicionado ao matrigel.

4.2.2.3 Descrição e preparação do Matrigel.

4.2.3 Identificação dos APTII isolados.

4.2.3.1 Avaliação ultraestrutural através de microscopia eletrônica.

4.2.3.2 Tetróxido de ósmio/ácido tânico.

4.2.3.3 Caracterização do citoesqueleto de actina dos APTII isolados

4.2.4 Imunofluorescência

4.2.4.1 Preparação das laminas cobertas com gelatina. 
4.2.4.2 Preparo dos tecidos para imunoistoquimica.

4.2.4.3 Imunoflorescência dos APTII em cultura primaria.

4.2.4.4 Aquisição de Imagens

4.2.5 Western blot.

4.2.5.1 Preparação das amostras.

4.2.5.2 Quantificação de proteínas.

4.2.5.3 Eletroforese em gel de poliacrilamida sob condições denaturantes.

4.2.5.4 Eletro-transferência das proteínas.......

4.2.5.5 Imunodetecção das proteínas de interesse.......

4.2.5.6 Westernblot das conexinas provenientes dos tecidos.......

4.2.6 Caracterização da cultura de APTII.

4.2.6.1 Avaliação da capacidade de comunicação dos APTII através da técnica de Scrape-loading.....

4.2.6.2 Capacidade de proliferação dos APTII.

RESULTADOS

5.1 RESULTADOS OBTIDOS NA FMVZ-USP.

5.1.1 Genotipagem.

5.1.2 Carcinogênese pulmonar.

5.1.2.1 Características genotípicas da prole de camundongos $\mathrm{C} \times 43^{+/-}$utilizados no experimento de carcinogênese.

5.1.2.2 Evolução do peso corpóreo dos camundongos $\mathrm{C} \times 43^{+/-}$e $\mathrm{C} \times 43^{+/+}$ durante o experimento de carcinogênese pulmonar.

5.1.2.3 Incidência de lesões macroscópicas nos camundongos iniciados com a uretana. 
5.1.2.4 Incidência de lesões macroscópicas espontâneas nos camundongos $\mathrm{C} \times 43^{+/-}$

5.1.2.5 Quantificação das lesões pulmonares microscópicas em sistema de análise de imagens

5.1.3 Classificação histológica dos adenomas......................................... 162

5.1.4 Quantificação das células positivas para o PCNA ............................. 165

5.1.5 Imunoblote das Cxs 43, 26, 32 e 46................................................ 168

5.1.5.1 Imunoblote da Cx43.................................................................. 168

5.1.5.2 Imunoblote da Cx26, 32 e 46..................................................... 170

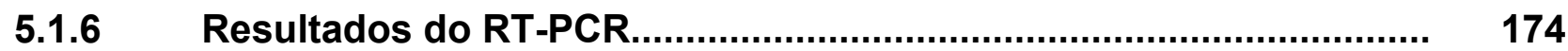

5.1.6.1 PCR em tempo real para a Cx43 ................................................. 174

5.1.6.2 PCR em tempo real para as Cx26, Cx32 e Cx46............................... 177

5.1.6.2.1 Resultados referentes à expressão da Cx26 pela técnica de Real Time PCR.

5.1.6.2.2 Resultados referentes à expressão da Cx32 pela técnica de Real Time PCR.

5.1.6.2.3 Resultados referentes à expressão da Cx46 pela técnica de Real Time PCR.

5.1.7 Immunoistoquímica para a Cx43 nos tecidos pulmonares tratados ou não com uretana.

5.1.8 Imunomarcação da Cx26 no tecido pulmonar submetido ou não ao tratamento com uretana e nos respectivos adenomas.

5.1.9 Imunomarcação da $\mathrm{C} \times 32$ no tecido pulmonar submetido ou não ao tratamento com uretana e nos respectivos adenomas.

5.1.10 Imunomarcação da Cx46 no tecido pulmonar submetido ou não ao tratamento com uretana e nos respectivos adenomas. 
5.2 RESULTADOS DOS ESTUDOS IN VITRO OBTIDOS NA UNIVERSIDADE DE POITIERS.

5.2.1 Estabelecimento da cultura celular primária dos APTII.................... 217

5.2.2 Expressão de conexinas nas APTII em cultura primária................... 227

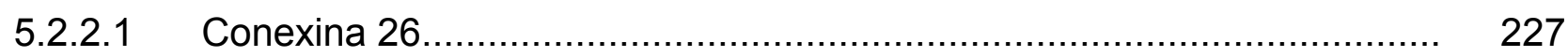

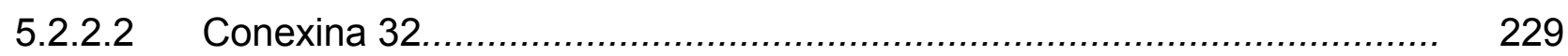

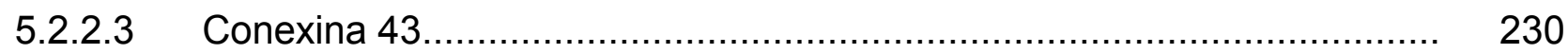

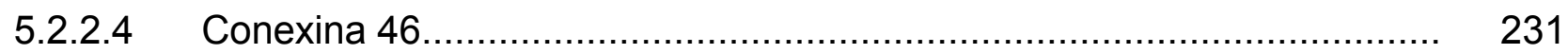

5.2.3 Localização das conexinas 26, 32, 43 e 46 in vivo utilizando a técnica de imunofluorescência....................................................... 233

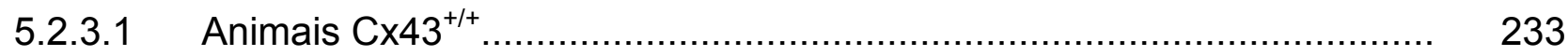

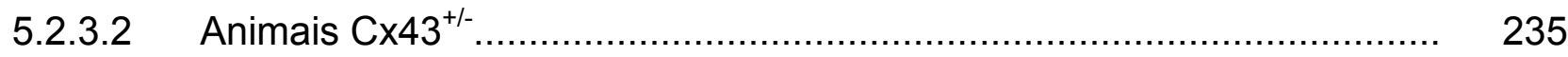

5.2.4 Dupla marcação para as conexinas 26, 43, 46 e APTII ao mesmo tempo.

5.2.5 Análises de Western blot das conexinas presentes nos APTII em cultura primária

5.2.6 Efeito da menor expressão do gene da conexina 43 sobre a comunicação das APTII avaliadas pela técnica de scrape-loading e transferência do corante.

5.2.7 Avaliação da capacidade de proliferação dos pneumócitos do tipo II em cultura primária

DISCUSSÃO.

REFERÊNCIAS. 


\section{INTRODUÇÃO}

s células que compõem os tecidos de um organismo vivo contêm na
membrana plasmática áreas onde se encontram estruturas especializadas denominadas junções celulares. Descrevem-se três tipos de junções celulares, classificados de acordo com a principal função que desempenham (ALBERTS et al., 1994). As junções de ancoramento promovem a adesão de uma célula à outra ou a elementos da matriz extracelular. As junções de oclusão atuam no sentido de restringir a passagem de substâncias pelo espaço entre as células, principalmente as da pele. E, por fim, as junções comunicantes do tipo GAP, tema desta tese, promovem, como o nome indica, a comunicação entre as células.

Em um organismo, praticamente todas as células estão interligadas por meio de junções do tipo GAP (as células sangüíneas, que geralmente não se associam, as musculares esqueléticas e grande parte das células nervosas são, usualmente, exceções). Formadas por proteínas inseridas na membrana plasmática, as conexinas, tais junções formam verdadeiros "túneis" que ligam diretamente o citoplasma de células adjacentes. Atualmente estas junções são mais comumente conhecidas pelo nome da proteína (conexina) que compõem o canal. Assim, num determinado órgão, as células estão todas interconectadas por meio dessa rede, fazendo com que estas se comuniquem por meio de uma estrutura única conduzindo informações essenciais, principalmente para o controle do crescimento.

Cada célula de um par em contato contribui com a metade do canal juncional (o conexon), que se deixa atravessar por moléculas, neutras ou carregadas, de dimensões apreciáveis. Esta baixa seletividade faz com que várias moléculas 
biologicamente importantes possam atravessar os canais juncionais, transitando livremente entre as células que compõem um determinado tecido.

O tecido pulmonar é constituído basicamente pelos alvéolos que são, por sua vez, constituídos na sua quase totalidade pelos pneumócitos do tipo I e os do tipo II. O pulmão é um órgão cujas células estão submetidas a estresse ambiental, sendo necessário a constante renovação da estrutura respiratória de uma maneira estritamente controlada. Entre os íons que permeiam pelas conexinas e que desempenham importante papel fisiológico nos alvéolos, encontra-se o íon $\mathrm{Ca}^{+2}$. Este participa de vias de sinalização, controlando desde a síntese de proteína surfactante até a apoptose nos pneumócitos do tipo II.

Numerosos relatos têm abordado o controle do crescimento tumoral pelas junções comunicantes do tipo gap. Comprovar através de estudos in vivo a participação destas proteínas na carcinogênese torna-se extremamente importante e desafiador já que o gene que codifica para esta proteína raramente tem sido encontrado mutado nos tumores, apenas com expressão reduzida ou apresentando localização aberrante da proteína. Desta maneira, estudar o modo como Cx43 pode atuar na carcinogênese pulmonar é um passo importante para o entendimento da regulação da sua expressão e as possíveis modificações pós-transcrição.

Os camundongos geneticamente modificados tornaram-se a principal ferramenta para atingirmos nossos propósitos. O camundongo knockout para a Cx43 $\left(\mathrm{C} \times 43^{-/-}\right)$foi desenvolvido há aproximadamente uma década (REAUME et al., 1995) e se mostrou extremamente útil para estudos sobre a participação da Cx43 na fisiopatologia cardíaca. Até o presente, apenas um estudo sobre carcinogênese (cutânea) foi realizado utilizando tal camundongo (YAMAKAGE et al., 2000). A idéia de se utilizar este camundongo para se avaliar a participação da Cx43 na 
carcinogênese pulmonar partiu da observação de que camundongos heterozigotos $\left(\mathrm{C} \times 43^{+/}\right)$tratados com dietilnitrosamina apresentavam focos tumorais no pulmão em maior quantidade que os camundongos selvagens $\left(\mathrm{C} \times 43^{+/+}\right)$. Este estudo foi então, idealizado para se avaliar a real importância desta proteína no epitélio pulmonar, utilizando-se desta vez, um carcinógeno específico para se induzir a carcinogênese pulmonar.

Neste trabalho de tese nós nos propusemos a avaliar a susceptibilidade, a importância e a localização das conexinas envolvidas na carcinogênese pulmonar induzida pela uretana, bem como a capacidade de comunicação das células epiteliais pulmonares extraídas e cultivadas in vitro. Para tanto nós nos valemos de técnicas de biologia molecular aplicadas à Patologia, que foram de extrema importância para se demonstrar o fato da Cx43 ser a principal conexina expressa no epitélio pulmonar. 


\section{REVISÃO DA LITERATURA}

\subsection{CONHECIMENTO ATUAL SOBRE AS JUNÇÕES DO TIPO GAP E SITUAÇÃO DO TEMA DE PESQUISA}

\subsubsection{Organização molecular das junções comunicantes do tipo gap}

s junções comunicantes do tipo gap (GJIC) foram descritas pela primeira
vez no final dos anos 60 . O termo "junção comunicante do tipo gap" é utilizado com a finalidade de descrever estas regiões especializadas onde as membranas plasmáticas de duas células adjacentes se reaproximam sem se fundir, delimitando um espaço intermembranas ou "gap" estimado em 2-3 nm (setas vermelhas Figura 1A), em relação aos 15 a $20 \mathrm{~nm}$ (setas azuis Figura 1A) que separam duas células vizinhas. A observação em microscópio eletrônico mostrou que as GJIC apresentam uma estrutura pentalaminar característica como descrito na figura 1B, constituindo verdadeiras placas juncionais nesta região (Figura 1C e D).

Após 1977, com os métodos de cristalografia e de difração de raios-X, imagens obtidas por difração óptica efetuadas sobre frações de membranas ricas em GJIC, permitiram a Makowski propor um modelo de organização da placa juncional (Figura 2). (MAKOWSKI et al., 1977). Neste modelo, ainda atual, cada placa é composta por vários canais intercelulares constituído pela associação em face a face de estruturas hexaméricas de $7 \mathrm{~nm}$ de diâmetro chamadas de conexons (detalhe círculo vermelho, Figura 2). Cada conexon é constituído de seis subunidades protéicas que atravessam a membrana: as conexinas (Cx), que quando oligomerizadas formam um poro central hidrofílico de cerca de $2 \mathrm{~nm}$ de diâmetro 
(MAKOWSKI ET AL., 1977; UNWIN; ZAMPIGHI, 1980). O tamanho e o número de placas juncionais variam muito de um tipo celular para outro e dependem freqüentemente do estado de atividade dos tecidos (BEYER, 1993; DERMIETZEL ET AL., 1990). Em certos casos, as placas podem atingir até $1 \mu \mathrm{m}$ (Figura 1C).
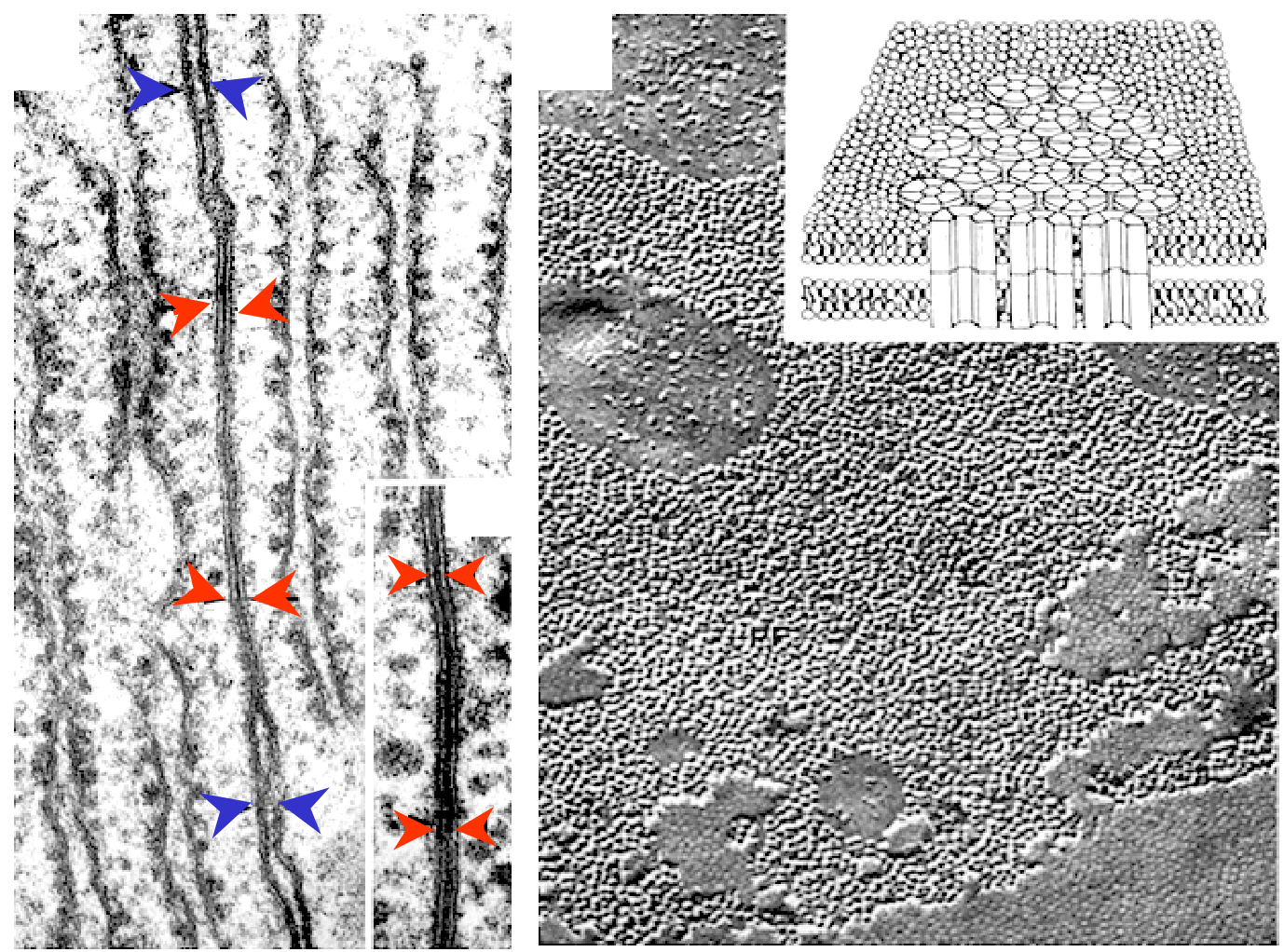

Figura 1 - A. Observa-se a região mais distante entre as células (flechas azuis) e a região onde há íntimo contato entre as células com máximo de aproximação (flechas vermelhas). B. Representação da estrutura pentalaminar na região de contato (três "faixas" mais elétron densas e duas menos eletro densas). C. Eletromicrografia de varredura da placa juncional após criofratura. D. Representação esquemática da placa juncional mostrando os canais formados pelas conexinas descritos em detalhe na figura 2 


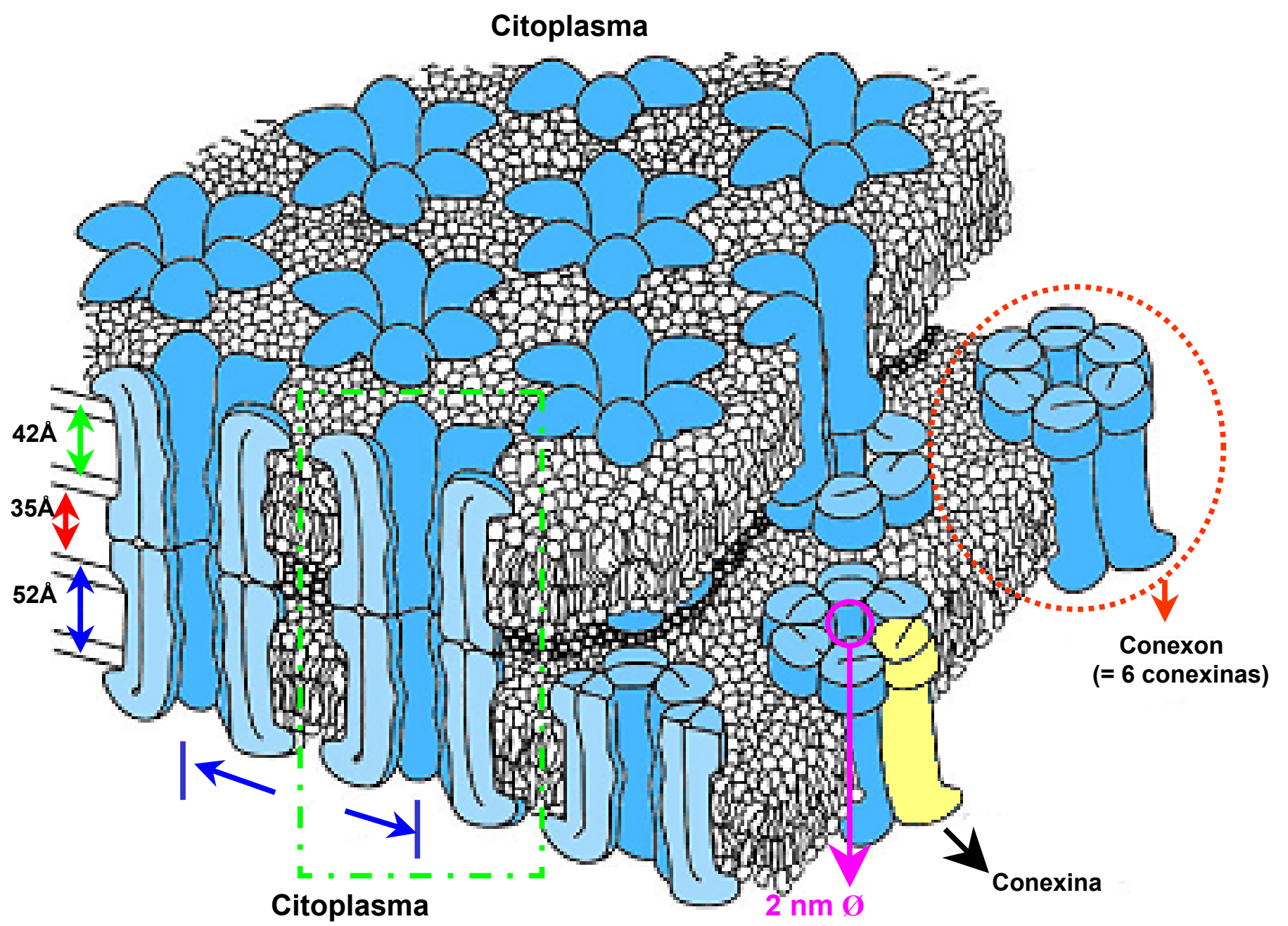

Figura 2 - Modelo de organização da placa juncional proposta por Makowski et al. (1977) estabelecida a partir de estudos de microscopia eletrônica e de estudos de difração de raios $\mathrm{X}$ de junções gap de fígado de camundongos. Cada conexon (circulo vermelho) é formado por seis subunidades de conexinas (representadas em amarelo/azul) delimitando um poro central (em rosa) e está estritamente associado a outro conexon na membrana adjacente (quadrado verde) 


\subsection{AS PROTEÍNAS QUE COMPÕEM AS JUNÇÕES DO TIPO GAP: AS CONEXINAS}

\subsubsection{Uma família de genes}

Após 1986, vários genes que codificam para diferentes conexinas foram clonadas em mamíferos, em frangos, em Xenopus (sapo africano) e em peixes (Tabela 1A e 1B). A fim de se distinguir as diferentes conexinas clonadas, foi necessário adotar uma nomenclatura específica. A nomenclatura correntemente utilizada (e de maior aceite pela comunidade científica) faz referência ao tamanho da proteína predita a partir da seqüência do cDNA considerado (em kDa) precedida do termo genérico Cx (BEYER et al., 1987). As Cxs homólogas entre as diferentes espécies são diferenciadas utilizando, no sufixo, uma abreviação precisando a espécie, por exemplo, "r" para o rato, "m" para camundongo (mouse) ou ainda "h" para humano. Em certos casos, algumas conexinas identificadas apresentam massas moleculares muito próximas, fazendo-se necessário empregar um número decimal: é o caso para diferenciar a conexina 31 da conexina 31.1 (HENNEMANN et al., 1992a; WILLECKE et al., 1991a).

Existe ainda, uma nomenclatura alternativa, que é baseada na análise filogenética das diferentes Cxs, isto é, baseada nas homologias das seqüências de nucleotídeos (KUMAR; GILULA, 1992) (Figura 3). Efetivamente, foi proposto que os genes das Cxs originam-se de uma seqüência original, ainda indeterminada, que teria sofrido ao menos uma duplicação no início ou imediatamente antes da evolução dos vertebrados, dando origem à separação entre as subclasses $\alpha, \beta$ e $\gamma$ (ou $\delta$ ) (BENNETT et al., 1991; O’BRIEN et al., 1998). 


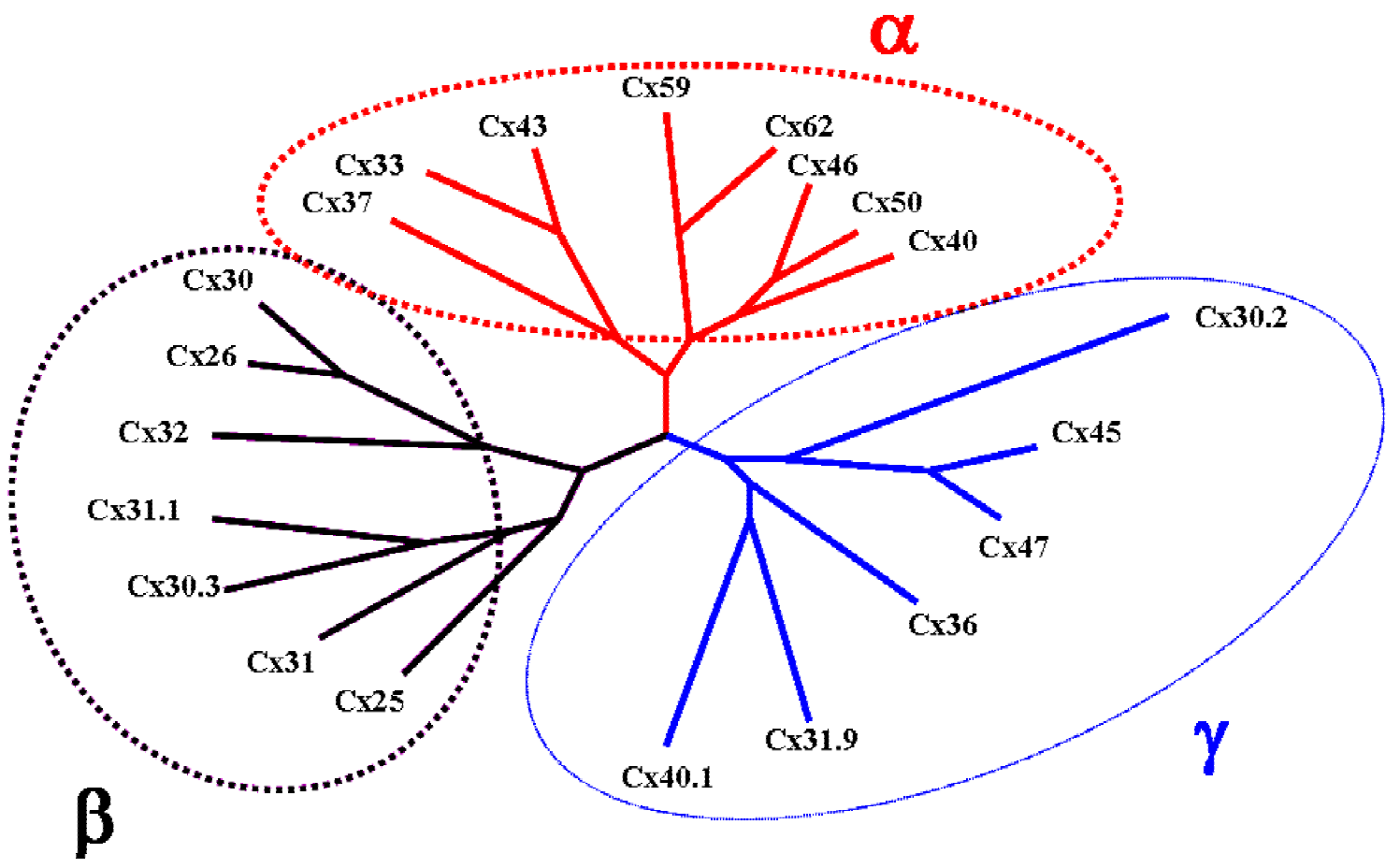

Figura 3 - Família multigênica das conexinas derivadas de um provável ancestral comum (Imagem cedida por M. Mesnil). As conexinas são divididas em 3 subclasses de acordo a estrutura do gene que as codificam (detalhe Figuras 4 e 5)

Nesta nomenclatura, cada Cx é nomeada pela classe na qual ela aparece $(\alpha$, $\beta \ldots$ ), seguido do número da ordem de sua identificação. Por exemplo, a Cx32 (lê-se conexina32) aparece na classe $\beta$ e foi a primeira $C x$ identificada nesta classe assim, ela é identificada como $\beta 1$ (PAUL, 1986) (Tabela 1A). A tabela 2 recapitula todas as conexinas descobertas humanos até hoje e seus ortólogos descobertos no camundongo (WILLECKE et al., 2002). Dentre as nomenclaturas, há consenso geral, para a adoção do termo Gj (Gap junction), seguido da classe $(\alpha, \beta, \gamma)$ acrescido da ordem de sua descoberta em cada grupo quando se faz Referência ao gene, para 
esclarecimentos verificar a tabela 1C. Esta nomenclatura não será adotada nesta tese, com exceção para compilações já publicadas.

Após o congresso de Cxs no Hawai de 2001 (International Gap Junction Conference, Honolulu, Hawaii, USA), publicado na sua integra no periódico Cell Communication and Adhesion, a comunidade científica vem tentando utilizar a nomenclatura Gj seguida da classe à qual a conexina pertence (WILLECKE, 2003).

Todas as Cxs descobertas são codificadas por genes diferentes, localizados em cromossomos distintos. Por exemplo, o gene da Cx32h esta localizada no cromossomo X, já o dá Cx43h está situado no cromossomo 6 e o dá Cx26h no cromossomo 13 (WILLECKE et al., 1990). Para a maioria das Cxs estudadas, a estrutura de seu gene é simples e muito conservada. Ela apresenta uma particularidade de conter a seqüência codificante em único éxon (o éxon 2). Os genes das Cxs geralmente apresentam dois éxons separados por um íntron de tamanho variável (3,5 a $11 \mathrm{~kb})$. O primeiro éxon, de pequeno tamanho $(0,1 \mathrm{a} 0,5 \mathrm{~kb})$, corresponde a uma seqüência 5' não traduzida (UTR), enquanto que o segundo éxon corresponde à totalidade da seqüência codificante por entre seqüências 5'e 3' UTR (Figura 4A). Entretanto, há algumas exceções no esquema geral das Cxs, sobretudo para o gene da Cx32, cuja organização é mais complexa. Como mostra a figura 4B, o gene da $\mathrm{Cx} 32$ de camundongo contém 4 éxons: 3 éxons de pequeno tamanho contendo seqüências 5'UTR (éxons 1, 1a e 1b) e um quarto éxon (éxon 2) contendo a seqüência codificante (DUGA et al., 1999; SÖHL et al., 1996). O gene da Cx32h contém apenas 3 éxons (éxon 1, 1b e 2) (NEUHAUS et al., 1996). Em estudos mais recentes sobre as seqüências de Cxs caracterizadas revelou uma nova classe de conexina, a classe $\delta$ (ou $\gamma$ segundo os autores), cujos genes têm uma estrutura diferente. Nesta classe, o gene compreende 2 éxons, a seqüência 
codificante é repartida em 2 éxons e é interrompida por uma seqüência intronica (Figura 4C) (CONDORELLI et al., 1998; O’BRIEN et al.; 1998B).

Quando se acessa o GenBank, o que se verifica é que a distância que separa os éxons 1 e 2 de camundongos é muito variada em relação aos $10.5 \mathrm{~Kb}$ anteriormente descritos para a Cx43. Recentemente, a estrutura de gene que codifica para a Cx43 de camundongos foi redefinida identificando nove novas espécies de mRNA da Cx43 (GenBank NM010288, e AY427554 a AY427561) produzidos pela utilização de mecanismos de splicing alternativos (PFEITER et al., 2004). Tal trabalho identificou três promotores alternativos e seis diferentes éxons (Figura 5) e revelou a intrincada regulação do gene da Cx43 nos diferentes níveis: transcrição, splicing do pré mRNA e a tradução. Este trabalho revelou que no pulmão basicamente é utilizado a éxon1A-éxon2, no entanto, o fato de alguns órgãos utilizarem promotores específicos ainda vem sendo estudado. 
Tabela 1A - Conexinas identificadas até os dias de hoje

\begin{tabular}{|c|c|c|c|c|c|c|}
\hline Cx & $\begin{array}{l}\text { RNAm } \\
\text { (Kb) }\end{array}$ & $\begin{array}{l}\text { Proteína } \\
\text { (kDa) }\end{array}$ & a.a. & $\begin{array}{l}\text { Banco de cDNA } \\
\text { Genômico }\end{array}$ & Distribuição tecidual & Referências \\
\hline Cx26 $\beta 2$ & 2,5 & 26,5 & 226 & $\begin{array}{l}\text { Fígado } \\
\text {-Rato }^{(1)}-\text { Homem }^{(2)} \text {-Camundongo } \\
\text { Camundongo }^{(4)}\end{array}$ & $\begin{array}{l}\text { Hepatócitos } \\
\text { Células secretoras das glândulas endócrinas e } \\
\text { exócrinas } \\
\text { Determinados queratinócitos } \\
\text { Determinadas células hepiteliais } \\
\end{array}$ & \multirow{11}{*}{$\begin{array}{l}\text { 1- ZHANG E NICHOLSON, } 1989 \\
\text { 2- LEE et al., } 1992 \\
\text { 3- NISHI et al., } 1991 \\
\text { 4- HENNEMANN et al., 1992a } \\
\text { 5- DAHL et al., } 1992 \\
\text { 6- HENNEMANN et al., 1992b } \\
\text { 7- WILLECKE et al., 1991a } \\
\text { 8- HENNEMANN et al., 1992c } \\
\text { 9- HOH et al., } 1991 \\
\text { 10- HAEFLIGER et al., 1992 } \\
\text { 11- HEYNKES et al, 1986 } \\
\text { 12- PAUL, 1986 } \\
\text { 13- KUMAR E GILULA, } 1996 \\
\text { 14- DUGA et al., 1999 } \\
\text { 15- MILLER et al., 1988 } \\
\text { 16- SÖHL et al.,, 1996 } \\
\text { 17- CONDORELLI et al., 1998 } \\
\text { 18- WILLECKE et al., 1991a } \\
\text { 19- REED et al., 1993 } \\
\text { 20- HENNEMANN et al., 1992c } \\
\text { 21- BEYER et al., 1987 } \\
\text { 22- KANTER et al., 1992a } \\
\text { 23- KANTER et la., 1992b } \\
\text { 24- BEYER et al., 1987 } \\
\text { 25- FISHMAN et al., 1990 } \\
\text { 26- LASH et al., 1990 } \\
\text { 27- LANG et al., 1991 } \\
\text { 28- GUPTA et al., 1994 }\end{array}$} \\
\hline $\mathrm{C} \times 30 \beta 6$ & 2,3 e 2,0 & 30,3 & 261 & Camundongo $\star^{(5)}$ & $\begin{array}{l}\text { Cérebro } \\
\text { Queratinócitos }\end{array}$ & \\
\hline $\begin{array}{c}\mathrm{C} \times 30.3 \\
\beta 5\end{array}$ & 3,2 e 1,8 & 30,4 & 266 & $\begin{array}{l}\text { Linhagem (camundongo) } \\
\text { - F9 }{ }^{(6)} \text { Camundongo }{ }^{\star(7)}\end{array}$ & $\begin{array}{l}\text { Células dos blastocistos } \\
\text { Determinados queratinócitos }\end{array}$ & \\
\hline $\mathrm{Cx} 31 \beta 3$ & 2,3 e 1,9 & 31 & 270 & $\begin{array}{l}\text { Linhagem (camundongo) } \\
\text { - F9 }{ }^{(8)} \text { Rato }{ }^{\star(9)}\end{array}$ & $\begin{array}{l}\text { Determinados queratinócitos } \\
\text { Células dos blastocistos } \\
\text { Células da trofoectoderme placentária } \\
\text { Rins }\end{array}$ & \\
\hline $\begin{array}{c}\mathrm{C} \times 31.1 \\
\beta 4\end{array}$ & 1,6 & 31,1 & 271 & $\begin{array}{l}\text { Linhagem (camundongo) } \\
-\mathrm{F9}^{(6,7)} \text { Camundongo }^{\star(7)} \text { Rato }^{\star(10)}\end{array}$ & $\begin{array}{l}\text { Determinados queratinócitos } \\
\text { Células dos epitélios estratificados } \\
\text { Células dos blastocistos }\end{array}$ & \\
\hline $\mathrm{Cx} 32 \beta 1$ & 1,6 & 32 & 283 & 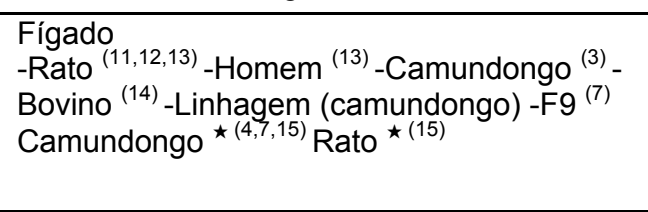 & $\begin{array}{l}\text { Maioria dos epitélios: } \\
\text { Hepatócitos, células secretoras das glândulas } \\
\text { exócrinas, epitélio folicular da tireóide } \\
\text { Rins } \\
\text { Determinados neurônios } \\
\text { Oligodendrócitos } \\
\text { Células de Schwann }\end{array}$ & \\
\hline$C \times 33 \alpha 7$ & 2,3 & 32,9 & 286 & Rato $\star(10)^{\prime}$ & Algumas células do testículo & \\
\hline $\begin{array}{l}\text { Cx36 } \\
(\delta \text { ou } \gamma)\end{array}$ & 2,9 & 36 & 321 & $\begin{array}{l}\text { Cérebro - Rato }{ }^{(16)} \\
\text { Retina } \\
- \text { Camundongo }{ }^{(16)} \text { Camundongo }{ }^{\star(17)}\end{array}$ & Neurônios & \\
\hline $\mathrm{C} \times 37 \alpha 4$ & 1,7 & 37,6 & 333 & $\begin{array}{l}\text { Cérebro } \\
\text { - Camundongo }{ }^{(7,18)} \\
\text { Cordão Umbilical } \\
\text {-Homem }^{(19)} \text { Camundongo }{ }^{\star(18)}{\text { Rato }{ }^{\star(10)}}^{(10)}\end{array}$ & $\begin{array}{l}\text { Determinadas células endoteliais } \\
\text { Determinados queratinócitos } \\
\text { Células musculares cardíacas } \\
\text { Estomago } \\
\text { Testículo } \\
\text { Ovário }\end{array}$ & \\
\hline $\mathrm{Cx} 40 \alpha 5$ & 3,5 & 40 & 358 & $\begin{array}{l}\text { Camundongo }^{\star(7,20)} \text { Rato }^{\star(10,21)} \text { Cadela }{ }^{\star(22)} \\
\text { Homem }\end{array}$ & $\begin{array}{l}\text { Determinadas células endoteliais } \\
\text { Célula dos blastócitos } \\
\text { Células do sistema de condução cardíaca }\end{array}$ & \\
\hline $\mathrm{Cx} 43 \alpha 1$ & 3,2 & 43 & 382 & 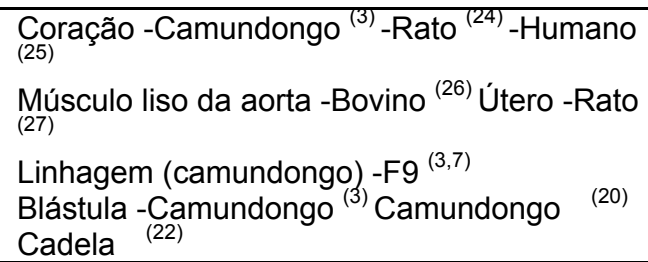 & $\begin{array}{l}\text { Epitélio do cristalino e da córnea } \\
\text { Osteócitos. Astrócitos. Leptomeninges. Leucócitos. } \\
\text { Macrófagos. Células musculares cardíacas. } \\
\text { Trofoblastos. Células musculares lisas. Células } \\
\text { secretoras das glândulas endócrinas: células } \beta \\
\text { pancreáticas, células de Leydig, células de Sertoli, } \\
\text { células tireoideanas. Determinados queratinócitos. } \\
\text { Blastócitos. Fibroblastos. }\end{array}$ & \\
\hline
\end{tabular}




\begin{tabular}{|c|c|c|c|c|c|c|c|}
\hline \multirow{8}{*}{ 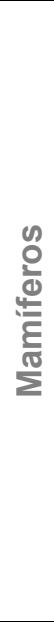 } & $\mathbf{C x}$ & $\begin{array}{l}\text { RNAm } \\
\text { (Kb) }\end{array}$ & $\begin{array}{l}\text { Proteína } \\
\text { (kDa) }\end{array}$ & a.a. & $\begin{array}{l}\text { Banco de cDNA } \\
\text { Genômico }\end{array}$ & Distribuição tecidual & Referências \\
\hline & $\mathrm{Cx44}$ & 2,5 & 44,4 & & Bovino $^{(28)}$ & Retina & \\
\hline & Cx45 $\alpha 6$ & 2,3 & 45 & 396 & $\begin{array}{l}\text { Linhagem (camundongo) } \\
\text {-F9 }^{(8)} \\
\text { Cão }^{(22)} \\
\text { Homem }^{(23)}\end{array}$ & $\begin{array}{l}\text { Células Musculares cardíacas } \\
\text { Células dos blastócitos } \\
\text { Células epiteliais do pulmão, dos rins, do } \\
\text { intestino, do cérebro (embrião) } \\
\text { Determinados queratinócitos }\end{array}$ & \\
\hline & $\mathrm{Cx} 46 \alpha 3$ & 2,8 & 45,6 & 416 & $\begin{array}{l}\text { Cristalino } \\
\text {-Rato } \\
\text { - } 99)\end{array}$ & $\begin{array}{l}\text { Fibras do cristalino } \\
\text { Células musculares } \\
\text { Células de Schwann, } \\
\text { Coração, Rins } \\
\end{array}$ & \\
\hline & Cx49 & 6,8 & 49,1 & 440 & Carneiro ${ }^{\star(30)}$ & Cristalino & \\
\hline & $\mathrm{Cx} 50 \alpha 8$ & 8,5 & 49,6 & 440 & Camundongo $^{\star(31)}$ & Fibras do cristalino e córnea & \\
\hline & Cx57 $\alpha 9$ & 3,5 & 57,1 & 505 & Camundongo $^{\star(32)}$ & $\begin{array}{l}\text { Coração, pulmão, Pele, Rins, Ovários, } \\
\text { Testículos, Intestino }\end{array}$ & \\
\hline & Cx60 & & & 528 & $\begin{array}{l}\text { Ovário } \\
\text {-Porco }\end{array}$ & $\begin{array}{l}\text { Teca interna e células cúmulos no ovário. } \\
\text { Cólon, Timos, Baço }\end{array}$ & \\
\hline \multirow{5}{*}{$\begin{array}{l}\text { 은 } \\
\text { 은 } \\
\text { 는 }\end{array}$} & $\operatorname{Cx} 42(\alpha)$ & 3,0 & 41,7 & 369 & $\begin{array}{l}\text { Embrião } \\
\text {-Frango }\end{array}$ & & \multirow{5}{*}{$\begin{array}{l}\text { 34- BEYER, } 1990 \\
\text { 35- MUSIL et al., } 1990 \\
\text { 36- JIANG et al., } 1994 \\
\text { 37- RUP et al., } 1993\end{array}$} \\
\hline & $\mathrm{Cx} 43(\alpha)$ & 3,0 & 43,2 & 381 & $\begin{array}{l}\text { Embrião } \\
\text {-Frango }\end{array}$ & & \\
\hline & $\operatorname{Cx45(\alpha )}$ & 2,0 & 45,4 & 394 & $\begin{array}{l}\text { Embrião } \\
\text {-Frango }\end{array}$ & & \\
\hline & $\begin{array}{c}C \times 45,6 \\
(\alpha)\end{array}$ & & & & Frango ${ }^{(36)}$ & & \\
\hline & $\operatorname{Cx56(\alpha )}$ & 8,0 & 55,9 & 510 & Frango $^{(3 /)}$ & & \\
\hline \multirow{4}{*}{ 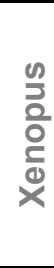 } & $\mathrm{Cx} 30(\beta)$ & 1,5 & 30,1 & 265 & $\begin{array}{l}\text { Fígado } \\
\text {-Xenopus } \\
{ }^{(38,39)}\end{array}$ & & \multirow{4}{*}{$\begin{array}{l}\text { 38- GIMLICH et al., } 1990 \\
\text { 39- GIMLICH et al., } 1990 \\
\text { 40- EBIHARA et al., } 1989 \\
\text { 41- YOSHIZAKI E PATINO, } 1995\end{array}$} \\
\hline & $\mathrm{Cx38}(\alpha)$ & 1,6 e 1,4 & 38 & 334 & $\begin{array}{l}\text { Ovário } \\
\text {-Xenopus }{ }^{(39,40)}\end{array}$ & & \\
\hline & $\mathrm{Cx} 41(\alpha)$ & 3,5 & 40,6 & & $\begin{array}{l}\text { Ovário } \\
\text {-Xenopus }{ }^{(41)}\end{array}$ & & \\
\hline & $\mathrm{Cx} 43(\alpha)$ & & 43 & 379 & $\begin{array}{l}\text { Ovário } \\
\text {-Xenopus }{ }^{(39)} \\
\end{array}$ & & \\
\hline \multirow{5}{*}{\begin{tabular}{l}
$\stackrel{x}{0}$ \\
\hdashline
\end{tabular}} & $\begin{array}{c}C \times 32,2 \\
(\alpha)\end{array}$ & & 32,2 & & $\begin{array}{l}\text { Ovário } \\
\text {-"Croaker" }{ }^{(42)}\end{array}$ & & \multirow{5}{*}{$\begin{array}{l}\text { 42- BRUZZONE et al., } 1995 \\
\text { 43- O'BRIEN et al., } 1998 \\
\text { 44- O'BRIEN et al., } 1996 \\
\text { 45- WAGNER et al., } 1998\end{array}$} \\
\hline & $\begin{array}{c}\mathrm{C} \times 32,7 \\
(\alpha)\end{array}$ & & 32,7 & & $\begin{array}{l}\text { Ovário } \\
\text {-"Croaker" }{ }^{(42)}\end{array}$ & & \\
\hline & $\begin{array}{c}\mathrm{C} \times 34,7 \\
(\delta 2 \text { ou } \gamma 2)\end{array}$ & 13 & 34,7 & 306 & $\begin{array}{l}\text { Retina } \\
\text {-Perca }\end{array}$ & Retina, Cérebro, Músculo liso & \\
\hline & $\begin{array}{l}\text { Cx35 }(\delta 1 \\
\text { ou } \gamma 1)\end{array}$ & 4,0 e 4,8 & 35,1 & 304 & $\begin{array}{l}\text { Retina } \\
\text {-Perca } \\
\text {-Raia } \\
{ }^{(43)}\end{array}$ & Retina, Cérebro & \\
\hline & $\begin{array}{c}\text { Cx43,4 } \\
\text { DACx43 } \\
(\alpha) \\
\end{array}$ & 3,0 & 43,3 & 381 & $\begin{array}{l}\text { Retina } \\
\text {-Danio gigante }{ }^{(45)}\end{array}$ & Retina, Cérebro & \\
\hline
\end{tabular}


Tabela1B - Comparação entre as conexinas identificadas até os dias de hoje no homem e no camundongo (WILLECKE et al., 2002)

\begin{tabular}{|c|c|c|c|c|c|}
\hline \multicolumn{3}{|c|}{ Camundongo } & \multicolumn{3}{|c|}{ Humano } \\
\hline Nome & $\begin{array}{c}\text { Massa } \\
\text { Molecular (Da) }\end{array}$ & Classe & Nome & $\begin{array}{c}\text { Massa Molecular } \\
\text { (Da) }\end{array}$ & Classe \\
\hline - & - & - & Cx25h & 25,892 & nd \\
\hline $\mathrm{Cx} 26 \mathrm{~m}$ & 26,411 & $\beta$ & Cx26h & 26,200 & $\beta$ \\
\hline $\mathrm{C} \times 29 \mathrm{~m}$ & 28,981 & nd & $\mathrm{C} \times 30.2 \mathrm{~h}$ & 30,313 & nd \\
\hline $\mathrm{Cx} 30 \mathrm{~m}$ & 30,366 & $\beta$ & Cx30h & 30,396 & $\beta$ \\
\hline Cx30.3m & 30,388 & $\beta$ & Cx30.0h & 30,419 & $\beta$ \\
\hline $\mathrm{C} \times 31 \mathrm{~m}$ & 30,901 & $\beta$ & Cx31h & 30,817 & $\beta$ \\
\hline Cx31.1m & 31,394 & $\beta$ & Cx31.1h & 31,088 & $\beta$ \\
\hline $\mathrm{C} \times 30.2 \mathrm{~m}$ & 30,219 & $\beta$ & Cx31.9h & 31,933 & $\beta$ \\
\hline $\mathrm{C} \times 32 \mathrm{~m}$ & 32,003 & $\beta$ & $\mathrm{C} \times 32 \mathrm{~h}$ & 32,024 & $\beta$ \\
\hline $\mathrm{C} \times 33 \mathrm{~m}$ & 32,860 & $\alpha$ & - & - & - \\
\hline Cx36m & 36,085 & nd & Cx36h & 36,248 & nd \\
\hline $\mathrm{C} \times 37 \mathrm{~m}$ & 37,596 & $\alpha$ & Cx37h & 37,413 & - \\
\hline Cx40m & 40,413 & $\alpha$ & Cx40h & 40,380 & - \\
\hline Cx39m & 39,996 & nd & Cx40.1h & 40,140 & nd \\
\hline $\mathrm{Cx} 43 \mathrm{~m}$ & 43,004 & $\alpha$ & Cx43h & 43,008 & $\alpha$ \\
\hline Cx45m & 45,665 & $\gamma$ & Cx45h & 45,482 & $\gamma$ \\
\hline Cx46m & 46,302 & $\alpha$ & Cx46h & 47,427 & $\alpha$ \\
\hline Cx47m & 46,603 & $\gamma$ & Cx47h & 46,655 & $\gamma$ \\
\hline \multirow[t]{2}{*}{ Cx50m } & 49,597 & $\alpha$ & Cx50h & 48,173 & $\alpha$ \\
\hline & & & Cx58h & 58,842 & nd \\
\hline Cx57m & 57,114 & $\alpha$ & Cx62h & 61,871 & $\alpha$ \\
\hline
\end{tabular}


Tabela 1C - Genes que fazem Referência a família das conexinas e sua distribuição cromossomal em camundongos e seres humanos. Uso da atual nomenclatura

\section{Cxs identificadas em camundongos}

Cxs identificadas em seres humanos

\begin{tabular}{|c|c|c|c|c|c|}
\hline$C x$ & GJ & $\mathrm{Cr}$ & $\mathrm{Cr}$ & GJ & $C x$ \\
\hline \multirow[t]{2}{*}{$\mathrm{Cx} 23 \mathrm{~m}$} & & 10 & 6 & & Cx23h \\
\hline & & & 6 & & Cx25h \\
\hline $\mathrm{C} \times 26 \mathrm{~m}$ & Gjb2 & 14 & 13 & GJB2 & Cx26h \\
\hline \multirow[t]{2}{*}{$C \times 29 m$} & Gje1 & 5 & 7 & GJE1 & $\mathrm{C} \times 30.2 \mathrm{~h}$ \\
\hline & & & & & $(\mathrm{C} \times 31.3 \mathrm{~h})$ \\
\hline $\mathrm{Cx} 30 \mathrm{~m}$ & Gjb6 & 14 & 13 & GJB6 & Cx30h \\
\hline $\mathrm{C} \times 30.2 \mathrm{~m}$ & Gja11 & 11 & 17 & GJA11 & $\mathrm{Cx} 31.9 \mathrm{~h}$ \\
\hline $\mathrm{C} \times 30.3 \mathrm{~m}$ & Gjb4 & 4 & 1 & GJB4 & $\mathrm{Cx} 30.3 \mathrm{~h}$ \\
\hline $\mathrm{C} \times 31 \mathrm{~m}$ & Gjb3 & 4 & 1 & GJB3 & Cx31h \\
\hline Cx31.1m & Gjb5 & 4 & 1 & GJB5 & Cx31.1h \\
\hline $\mathrm{C} \times 32 \mathrm{~m}$ & Gjb1 & $x$ & $x$ & GJB1 & $\mathrm{C} \times 32 \mathrm{~h}$ \\
\hline $\mathrm{Cx} 33 \mathrm{~m}$ & Gja6 & $x$ & & & \\
\hline $\mathrm{Cx} 36 \mathrm{~m}$ & Gja9 & 2 & 15 & GJA9 & Cx36h \\
\hline $\mathrm{C} \times 37 \mathrm{~m}$ & Gja4 & 4 & 1 & GJA4 & Cx37h \\
\hline Cx39m & & 18 & 10 & & $\mathrm{Cx} 40.1 \mathrm{~h}$ \\
\hline $\mathrm{Cx} 40 \mathrm{~m}$ & Gja5 & 3 & 1 & GJA5 & Cx40h \\
\hline Cx43m & Gja1 & 10 & 6 & GJA1 & Cx43h \\
\hline $\mathrm{Cx} 45 \mathrm{~m}$ & Gja7 & 11 & 17 & GJA7 & Cx45h \\
\hline $\mathrm{Cx} 46 \mathrm{~m}$ & Gja3 & 14 & 13 & GJA3 & Cx46h \\
\hline $\mathrm{Cx} 47 \mathrm{~m}$ & Gja12 & 11 & 1 & GJA12 & Cx47h \\
\hline \multirow[t]{2}{*}{$\mathrm{Cx} 50 \mathrm{~m}$} & Gja8 & 3 & 1 & GJA8 & Cx50h \\
\hline & & & 1 & GJA10 & Cx59h \\
\hline $\mathrm{Cx} 57 \mathrm{~m}$ & Gja10 & 4 & 6 & & Cx62h \\
\hline$\Sigma 20$ & & & & & $\Sigma 21$ \\
\hline
\end{tabular}

Esta tabela faz referência a atual seqüência de informações disponíveis no NCBI database (http:/www.ncbi.nlm.gov/genomes/state/euk...g.htm). Observação: Cx23m e Cx23h são proteína e genes preditos na database, o qual mostra somente duas cisteína nos seus loops citoplasmáticos. Cx31.1 é proveniente de uma isoforma de seu transcrito derivado da $\mathrm{C} \times 30.2 \mathrm{~h}$. $\mathbf{c r}=$ cromossomo. Adaptado de SÖHL e WILLECKE (2004). 


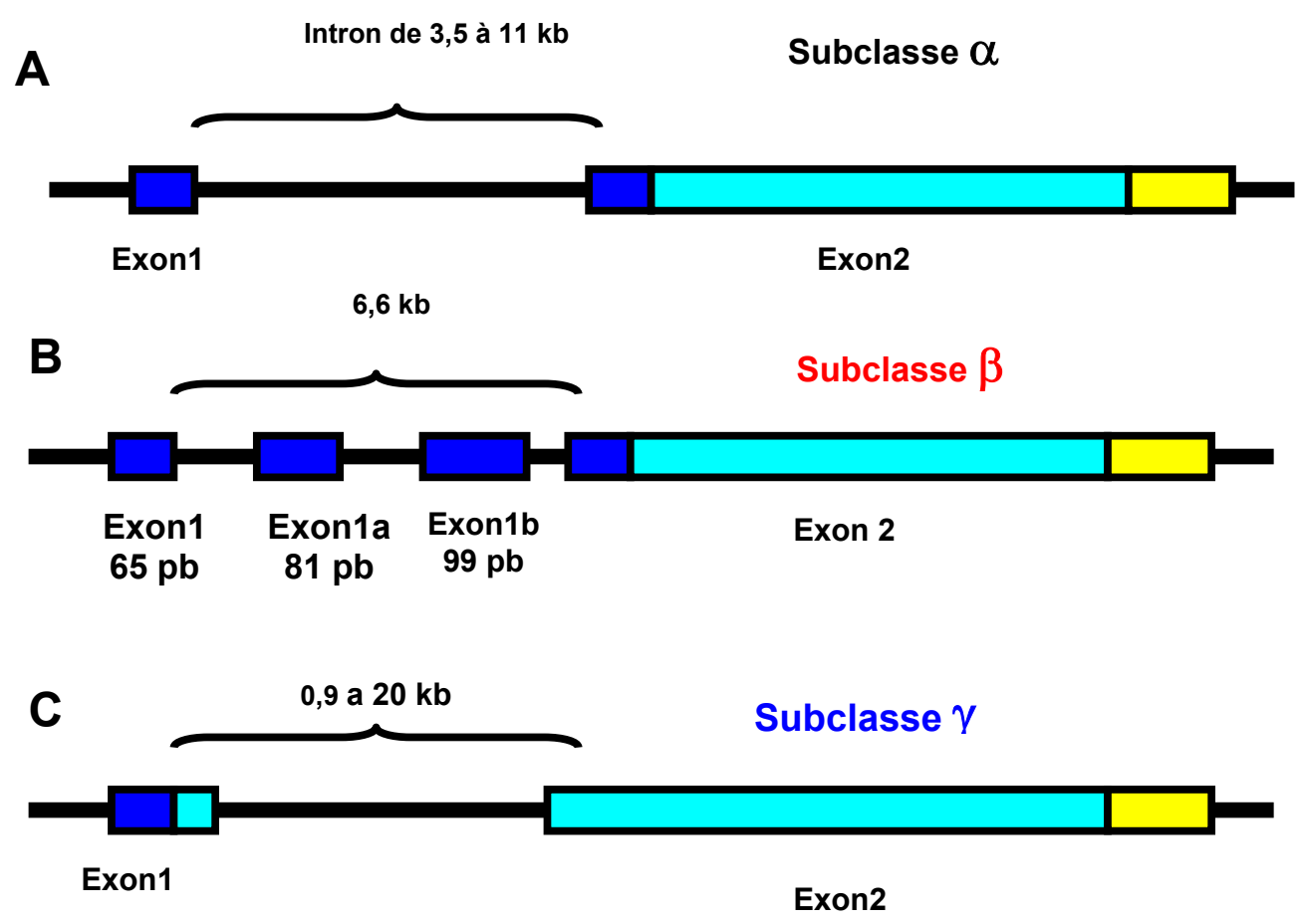

\section{$\square$ Região 5' UTR \\ $\square$ Região codificadora}

$\square$ Região 3' UTR

Figura 4 - Estrutura do gene das conexinas. A. Estrutura comum dos genes das conexinas pertencentes à subclasse $\alpha$, tais como aqueles da Cx43; B. Gene da Cx32 de camundongo, subclasse $\beta$; C. Gene das conexinas pertencentes à subclasse $\gamma$ : Cx36r; Cx35 arraia; Cx34.7 perca 


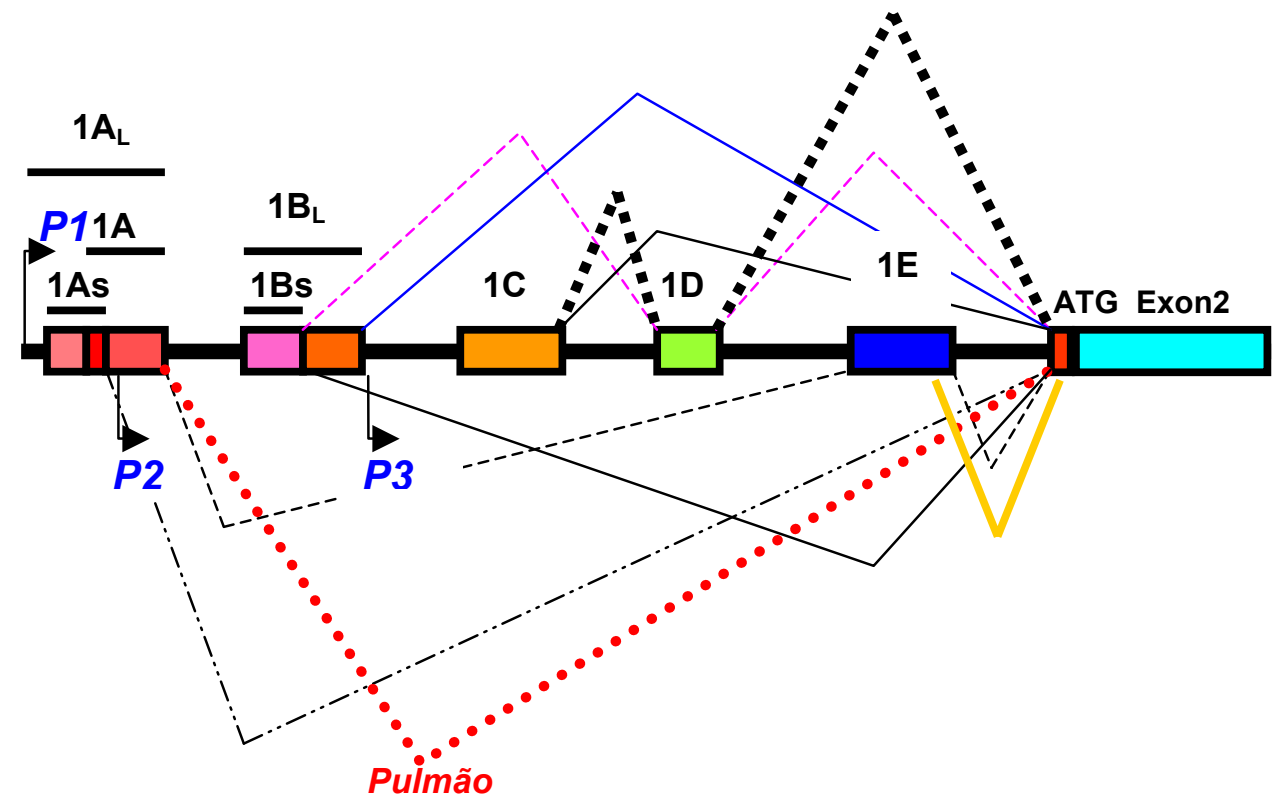

Figura 5 - Identificação das 6 novas regiões Cx43 5'-UTRs em camundongos. Diagrama mostrando a organização genômica dos novos éxons da Cx43, e as combinações dos splicing alternativos encontrados. Em vermelho está identificado o splincing que ocorre no pulmão ligando diretamente o éxon $1 \mathrm{~A}$ ao éxon 2. Adaptado de PFEITER et al. (2004). P1, P2 e P3 promotores identificados que são "utilizados" de acordo com a disponibilidade de fatores de transcrição do tecido. $\mathbf{L}=$ large; $\mathbf{s}=$ small; ATG = start códon, mais detalhe no texto 


\subsubsection{Uma família de proteínas}

As conexinas são proteínas transmembranares não glicosiladas de massa molecular aparente variando de 21 a $70 \mathrm{KDa}$. Os estudos de suas estruturas moleculares através de técnicas bioquímicas foram realizados a partir de frações subcelulares ricas em junções do tipo gap. A extração destas frações a partir do tecido só foi possível graças à relativa resistência destas placas juncionais à solubilização por determinados detergentes (N-Laurilsarcosina; Triton-X 100) ou por compostos alcalinos (hidróxido de sódio) (GOODENOUGH; STOECKENIUS, 1972; HERTZBERG; SKIBBENS, 1984). A primeira conexina identificada e caracterizada foi a Cx32 de fígado de rato. Após a obtenção da seqüência de aminoácidos da extremidade amioterminal da proteína pelo método de degradação de Edman, os oligonucleotídeos foram sintetizados e serviram como sondas para produzir bancos de cDNA de diferentes tecidos (HEYNKES et al., 1986; NICHOLSON et al., 1981; PAUL, 1986) ou ainda as proteínas originárias dos cDNA dos bancos foram identificadas por imunodetecção com a ajuda de anticorpos anti-Cx32. O cDNA da Cx32, uma vez identificado, foi utilizado como sonda para a identificação de outras conexinas. Esta técnica permitiu clonar o cDNA da Cx43 (BEYER et al., 1987). Até o

presente, 21 conexinas já foram identificadas em mamíferos (Tabelas 1A e 1B). A análise das seqüências primaria das Cxs, deduzidas da seqüência de seus cDNAs respectivos revelaram que, embora diferentes, todas compartilham um certo grau de homologia interespécie e interconexina. Por exemplo, há 97,6\% de homologia entre a Cx43r e a Cx43h e 95\% entre a Cx43m e Cx43r, e 98,5\%, entre a Cx32r e a Cx32h; e quase $50 \%$ de homologia entre as seqüências de aminoácidos das Cx32 e Cx43 de rato (nas regiões conservadas interCx). 


\subsubsection{Organização estrutural das conexinas}

Os perfis estabelecidos a partir de seqüências peptídicas de diferentes Cxs, e também de estudos de proteólise dirigida contra os domínios (loops) extramembranares e combinados com imunomarcação, com a utilização de anticorpos específicos dirigidos contra regiões determinadas das Cx, permitiram mostrar que todas as conexinas compartilham uma topologia comum (Figura 6A):

- 4 domínios hidrofóbicos muito conservados representando cada um, um segmento transmembrana: M1, M2, M3 e M4;

- 2 alças extracelulares E1 e E2 de cerca de 20-30 aminoácidos contendo cada uma 3 resíduos de cisteínas invariáveis em uma seqüência conservada: CX6CX3C na alça E1 e CX4CX5C na alça E2 (exceção no caso da Cx31 onde a seqüência da alça E2 é CX5CX5C) (DUPONT et al., 1989; HOH et al., 1991; RAHMAN; Evans 1991). Estes resíduos de cisteínas formam três pontes de dissulfeto interhélice intramolecular (Figura 6B) (DAHL et al., 1992; FOOTE et al., 1998).

- As extremidades aminoterminal (de cerca de 20 aminoácidos) e carboxiterminal bem como as hélices que ligam M1 a M3 (de 40 a 60 aminoácidos) são citoplasmáticas.

Desta maneira, os segmentos transmembra e a extremidade aminoterminal apresentam seqüências muito conservadas, e as seqüências da hélice citoplasmática e as extremidades carboxiterminal são muito variáveis em tamanho e em seqüência de uma Cx a outra. Como exemplo, no caso da Cx26r, a extremidade carboxiterminal tem 11 aminoácidos contra 60 aminoácidos da Cx32r e 145 
aminoácidos da Cx43r (BEYER et al.; 1987; PAUL, 1986; ZHANG; NICHOLSON, 1989). Estes domínios são os alvos de modificações pós-tradução de fato (fosforilação da extremidade carboxiterminal) ou potenciais (glicosilação da extremidade aminoterminal) (MUSIL et al., 1990; SAEZ et al., 1986; TRAUB et al., 1989). Estas regiões (pouco conservadas de uma Cx a outra) constituem a "carta de identidade" de cada conexina.

Muito pouco se sabe sobre o modo de replicação da cadeia polipeptídica da molécula de conexina com as técnicas aplicadas até o momento. Análises de dicroísmo circular permitiram mostrar que os segmentos transmembranares são organizados em $\alpha$-hélice (CASCIO et al., 1990). Este resultado está em acordo com os estudos de difração de raios X (TIBBITS et al., 1990) e foi mais recentemente confirmado nos trabalhos de Unger baseado na técnica de crio-cristalografia seguido de análises ao microscópio eletrônico em duas ou três dimensões com uma resolução de $7 \AA$ (UNGER et al., 1997; 1999; YEAGER; NICHOLSON, 1996). No que diz respeito aos domínios implicados na aproximação dos dois conexons face-aface, deixando a parte o fato de que eles asseguram um perfeito fechamento do canal em relação ao meio extracelular, poucos dados sobre sua estrutura secundária estão disponíveis. Isto é devido ao fato que estes domínios não são diretamente acessíveis pelas técnicas imunológicas por que eles estão fortemente unidos e os métodos que permitem dissociar as membranas ao nível de JG implicam em tratamentos invasivos (forte concentração de uréia ou de sacarose) (MANJUNTAH et al., 1984; PERKINS et al., 1997). Entretanto, Foote et al. (1998), com uma técnica de mutagênese dirigida com o objetivo de alterar 4 cisteínas das hélices E1 e E2, propôs um modelo no qual as hélices seriam organizadas em folhas $\beta$ antiparalelas, estabilizadas por pontes de dissulfeto inter-hélice, como ilustrado na figura $6 \mathrm{~B}$. 
Nenhum dado está disponível sobre a estrutura secundária das regiões citoplasmáticas. Considerando todas as razões, Unger et al. lançaram a hipótese de que estas porções teriam também uma estrutura ordenada em $\alpha$-hélice (UNGER et al., 1999). No que se diz respeito à extremidade aminoterminal sua inacessibilidade por técnicas imunológicas sugere que os sítios antigênicos, por uma replicação do polipeptídeo sobre ele mesmo ou inacessível por causa de uma estreita associação com a membrana plasmática (YEAGER; NICHOLSON, 1996). 
A

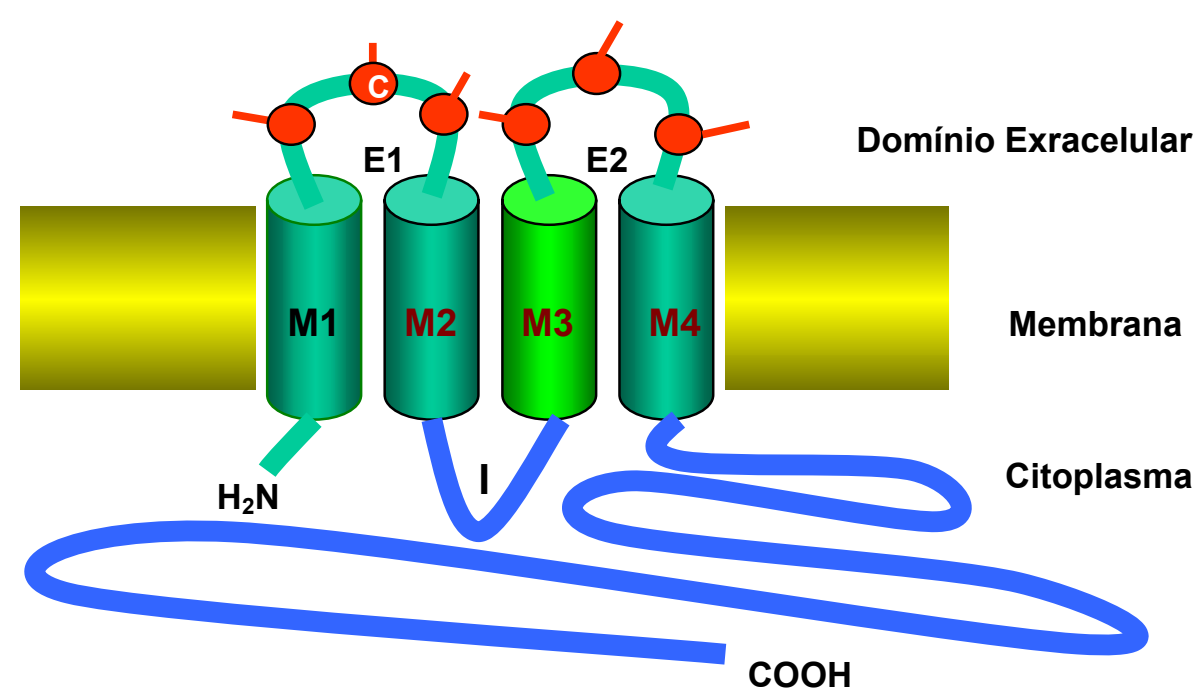

B

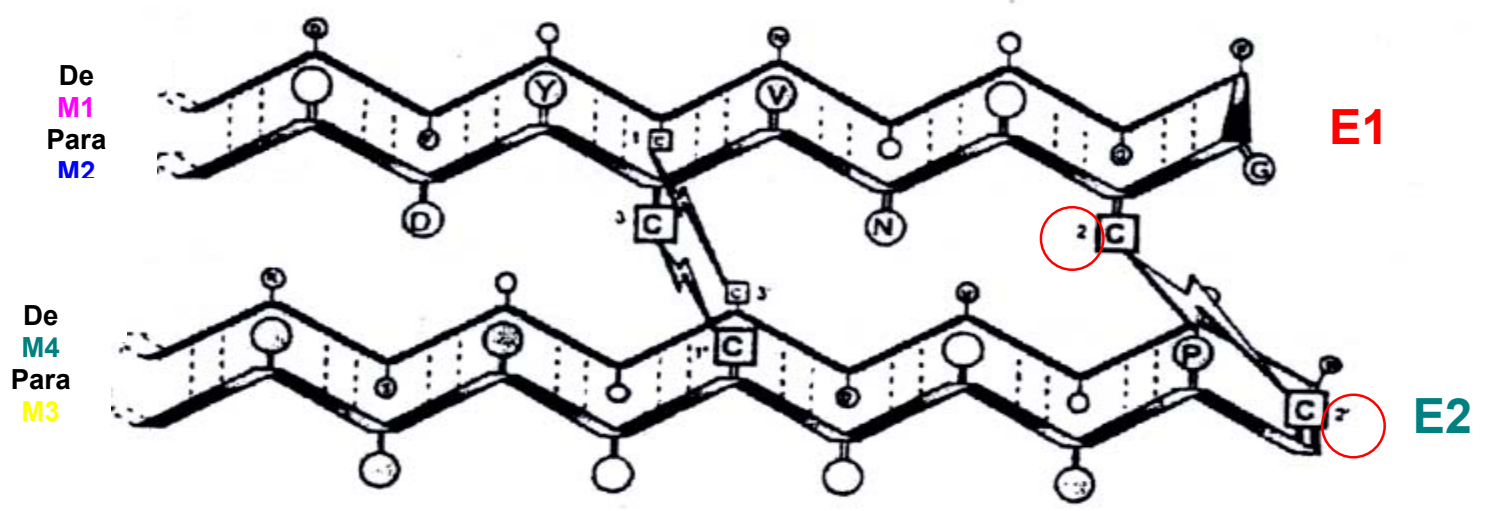

Figura 6 A - Topologia membranar de uma molécula de conexina. As regiões a porção amino terminal, os domínios transmenbrana e as alças extracelulares representam as seqüências mais conservadas entre as diferentes conexinas. Cada alça extracelular contém três cisteínas (vermelho) que são conservadas em todas as conexinas. $O$ domínio M3 (verde claro) tem uma característica anfipática que está diretamente relacionado com o movimento de fechamento da gap. Já os domínios citoplasmáticos (azul) correspondem às porções únicas em cada conexina, sendo, portanto, específicas (BEYER, 1993). B. Organização das alças extracelulares de uma conexina. Cada alça extracelular (E1 e E2) estão organizadas em folha $\beta$ antiparalela ligadas por três pontes de dissulfeto intramoleculares, entretanto a existência da ponte 2-2' ainda não foi demonstrada experimentalmente (circulo vermelho). Os resíduos hidrofóbicos são representados por círculos preenchidos enquanto que os resíduos hidrofílicos estão assinalados por círculos abertos. Os círculos metade preenchidos, metade abertos, são resíduos anfipáticos. (FOOTE et al., 1998). $\mathbf{N H}_{\mathbf{2}}$ : amina terminal; $\mathbf{C O O H}$ : carboxila terminal; I: alça intracelular; $\mathbf{M}$ : domínio transmembrana; E: alça extracelular 


\subsection{DIVERSIDADE DAS CONEXINAS}

\subsubsection{Distribuição tecidual das conexinas}

As conexinas estão distribuídas entre os diferentes tecidos de maneira muito complexa. Com exceção das células musculares estriadas adultas, os espermatozóides e das células circulantes sangüíneas, todos os tecidos expressam uma ou várias conexinas, uma mesma conexina é geralmente encontrada em vários tecidos ou tipos celulares. A tabela 2 apresenta alguns exemplos do perfil de expressão tecidual das conexinas dos mamíferos. A Cx43, por exemplo, é a conexina mais amplamente distribuída. Já as Cxs 33, 44 ou 31.1 apresentam um perfil de expressão mais restrito. Certas combinações entre as conexinas são freqüentemente encontradas. É o caso das conexinas 37 e 40 que são co-expressas em vários tecidos, mas a níveis diferentes. Quando várias conexinas são coexpressas, elas podem ser localizadas na mesma placa juncional como a Cx26 e a Cx32 nos hepatócitos ou em placas juncionais distintas como é o caso da Cx43 e da Cx32 nos epitélios foliculares da tireóide (GUERRIER et al., 1995). A multiplicidade e a especificidade da expressão das Cx, associadas à diversidade dos tipos celulares componentes e um dado tecido, complicam a determinação exata da função da comunicação intercelular de cada conexina expressa no tecido. Recentes trabalhos mostram que os canais juncionais possuem propriedades de permeabilidade que podem ser diferentes segundo as conexinas que os formam. 
Tabela 2 - Distribuição tecidual das conexinas (RNAm) de mamíferos

\section{Conexinas Distribuição tecidual}

Fígado; pâncreas; determinados queratinócitos; células do epitélio intersticial pinealócitos; cóclea interna; hipófise anterior; paratireóide; tireóide; rins; pulmão; baço; estômago; testículos; cérebro (células do sistema nervos); glândula mamária; útero; glândula salivar.

Cx30 ( $\beta 6) \quad$ Pulmão; estômago; cérebro; útero; pele, cristalino.

Cx30.3 (ß5) Blastócito; determinados queratinócitos (pele); rins.

Cx31 ( $\beta 1) \quad$ Determinados queratinócitos; blastócitos; células da trofoectoderma placentária; rins, testículos, olhos.

Cx31.1 ( $\beta 4)$ Determinados queratinócitos; células dos epitélios estratificados (pele); testículos.

\begin{tabular}{ll}
\hline Hepatócitos; determinados neurônios; oligodendrócitos; células de Schwann; \\
Cx32 ( $\beta 1)$ & $\begin{array}{l}\text { tireóide; rins; intestino; pulmão; baço; testículos; cérebro; glândula mamária; } \\
\text { pâncreas; glândula salivar. }\end{array}$
\end{tabular}

Cx33 (a7) Algumas células do testículo

Cx36( $\delta$ ou $\gamma$ ) Retina; cérebro (neurônios) $\begin{array}{ll}\text { Cx37 (a4) } & \begin{array}{l}\text { Determinadas células endoteliais; determinados queratinócitos; células } \\ \text { musculares cardíacas; testículos; ovários; neuroblastos corticais; rins; pulmão. }\end{array}\end{array}$

Cx40 ( $\alpha 5)$ Determinadas células endoteliais; células dos blastócitos; células do sistema de condução cardíaca; ovários; fibras de Purkinje; pulmão; útero.

Blastócitos; pele; córnea; fibroblastos; osteócitos; rins; glândula mamária; células musculares cardíacas; células epiteliais do pulmão; determinados queratinócitos;

Cx43 (a1) hipófise anterior; paratireóide; pâncreas endócrino; supra-renais; tireóide; testículos; ovários; miométrio; músculos lisos; células endoteliais; cristalino; astrócitos; células epiteliais renais tubulares; macrófagos; células do tecido conjuntivo.

\begin{tabular}{llll}
\hline Cx44 & Retina & & \\
\hline Cx45 $(\alpha 6)$ & $\begin{array}{l}\text { Células musculares cardíacas; blastócitos; células epiteliais do pulmão; } \\
\text { determinados queratinócitos; pele; coração; cérebro. }\end{array}$ \\
\hline Cx46 $(\alpha 3)$ & $\begin{array}{l}\text { Fibras do cristalino; células musculares cardíacas; células de Schwann; } \\
\text { pneumócitos do tipo II. }\end{array}$
\end{tabular}

Cx50 ( $\alpha 8) \quad$ Fibras do cristalino; células epiteliais da córnea.

Cx57 ( $\alpha 9) \quad$ Ovários; pele; coração; testículos; intestino; rins.

Cx60 Ovários; cólon; timo; baço. 


\subsubsection{Regulação da expressão dos genes das conexinas}

Em um mesmo tecido, a expressão dos genes que codificam para as conexinas, pode ser modificada dependendo da situação, notadamente no curso do desenvolvimento, condição fisiológica ou fisiopatológica particulares. Por exemplo, no útero, ocorre um aumento significativo da expressão da Cx43 no miométrio no momento do parto, resultado da ação conjunta de hormônios ovarianos e do estiramento mecânico das células necessárias à sincronização das contrações durante o nascimento. Esta regulação é tecido-específica, uma vez que no miocárdio, que também expressa a Cx43, a expressão desta conexina não é alterada neste período (LANG et al., 1991; OU et al., 1997; RISEK et al., 1990). Na glândula mamária, após o nascimento, nota-se um aumento do nível de expressão da Cx43 nas células mioepiteliais; o mesmo acontecendo para a Cx26 nas células epiteliais do lúmen (MONAGHAN et al., 1994; POZZI et al., 1995). Isto permite a contração coordenada das células implicadas na ejeção do leite. Tu et al. (1998) mostraram que a indução da Cx26 na glândula mamária sucedia o que acontecia no útero. Estes exemplos mostram que a expressão de uma mesma Cx pode ser diferentemente regulada segundo o tipo celular e que as expressões de diversas conexinas podem ser reguladas diferentemente no mesmo tipo celular. Para compreender esta especificidade na regulação da expressão das Cx, os autores procuraram identificar e caracterizar as regiões promotoras e reguladoras dos genes das conexinas. Atualmente, os genes mais estudados são os da Cx26, da Cx32 e o da Cx43.

$\mathrm{Na}$ região promotora do gene da Cx32, várias regiões reguladoras foram identificadas no camundongo: seqüências clássicas como as regiões $\underline{\text { GC Box que }}$ 
são locais de fixação de fatores de transcrição Sp1, as regiões GT Box que são locais de fixação de fatores de transcrição Sp3, uma região TATA Box (TTAAAA), um local de fixação do fator de transcrição NFKB. Além de seqüências menos dispersas como um elemento de resposta a determinados metais, e seqüências homólogas aos elementos de respostas ao AMPc ( $\underline{\mathrm{CRE}})$, um sítio de fixação do

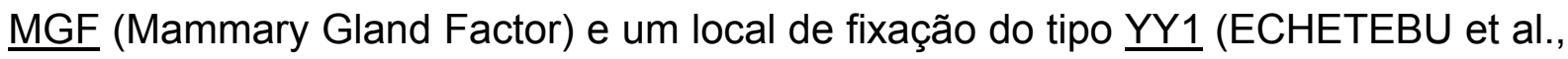
1999; HENNEMANN et al. 1992b; KIANG et al., 1997). Mais recentemente, Tu et al. (2001) mostraram a implicação do fator de transcrição AP2 no controle positivo da expressão da Cx26 durante a gravidez e no período da lactação.

Devido a sua organização, o gene da Cx32 se caracteriza por processos de regulação mais complexos (Figura 7). Dois promotores alternativos foram identificados no gene da Cx32 murino, humano e de bovino que são ativados de maneira tecido-específica. $\mathrm{O}$ primeiro promotor $(\mathrm{P} 1)$ se situa logo à frente do primeiro éxon. Ele controla a expressão do gene da Cx32 especificamente no fígado e pâncreas para o gene humano e murino e nos bovinos, controla a expressão no útero, nos rins, no intestino, nos testículos e nos ovários. Parece existir um nível suplementar de regulação já que Duga et al. 1999 descreveram a presença de dois transcritos oriundos de um estudo sobre o controle de P1 nos bovinos. Os dois transcritos têm a mesma distribuição tecidual, mas são expressos a níveis variáveis (DUGA et al., 1999). Apenas um destes transcritos é encontrado no homem e nos roedores (NEUHAUS et al., 1996; SÖHL et al., 1996). O estudo da região promotora P1 mostrou ausência da região TATA Box e a presença de locais consensos para os fatores de transcrição como o Sp1, NF-1 (Nuclear Factor-1), HNF-1 (Hepatic Nuclear Factor-1) e NFKB (BAl et al, 1995; HENNEMANN et al., 1992b; PIECHOCKI et al., 2000). Um segundo promotor (P2), situado acima do éxon precedente ao éxon 2, foi 
descrito em 3 espécies estudadas (rato, camundongo, homem e bovino). Ele controla a expressão de um transcrito contendo os éxons 1 b e 2 que são expressos apenas no tecido nervoso (células de Schwann). A região P2 possui seqüências homólogas aos elementos de resposta ao AMPc e uma TATA Box. Recentemente, Söhl et al. (2001) colocaram em evidência a presença de um transcrito alternativo, contendo o éxon 1a e o éxon 2, especificamente expressos nas células das camadas embrionárias de camundongos, nos oócitos e no fígado a um nível muito baixo (200 vezes que o transcrito "éxon 1- éxon 2"). Não foi mencionada a existência de um terceiro promotor. Além das regiões promotoras propriamente ditas, há regiões reguladoras nas regiões intronicas ou nas regiões não traduzidas (UTR).

A região promotora do gene da $\mathrm{Cx} 43$ contém uma região TATA Box degenerada, sítios AP1 e AP2, uma região GC, além de elementos de resposta ao estrógeno (SULLIVAN et al., 1993; YU et al., 1994). Foi demonstrado que a transcrição do gene da Cx43h nas células dos músculos lisos uterinos é induzida seguida da ativação da PKC através de um processo que requer a interação de cJun e c-Fos na região AP1 (GEIMONEN et al., 1996). Embora a expressão do gene da Cx43 apresentou-se aumentada em certos tipos celulares, consecutivamente à ativação da via de sinalização do AMPc, apenas um local degenerado do tipo CRE foi identificado (MEHTA et al., 1992). Chen et al. evidenciaram a presença de dois elementos reguladores específicos do gene da Cx43: um elemento inibidor cuja seqüência é muito próxima daquela da região SP1, mas cuja proteína que interage não se assemelha a SP1, e um elemento ativador que esta contida no promotor mínimo (CHEN et al., 1995a). Recentemente, Echetebu et al. (1999), em estudos relacionados ao aumento da expressão da Cx43 no miométrio antes do parto, identificaram quatro regiões reguladas na região do promotor basal do gene da Cx43 
interagindo com proteínas como c-Jun (em Ap1), SP1 (em SP1) ou ainda Ets/NFKB. Finalizando, Mitchell et al. (2001) mostraram que o promotor basal da região 3'UTR contém elementos de resposta ao hormônio paratireoideano. 
A

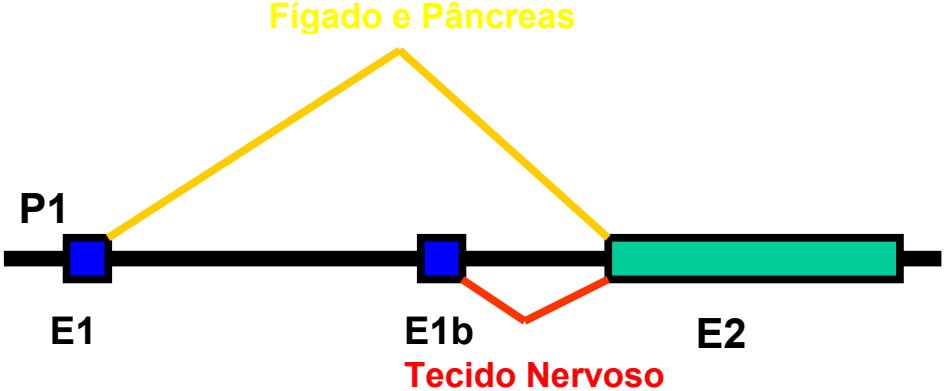

B

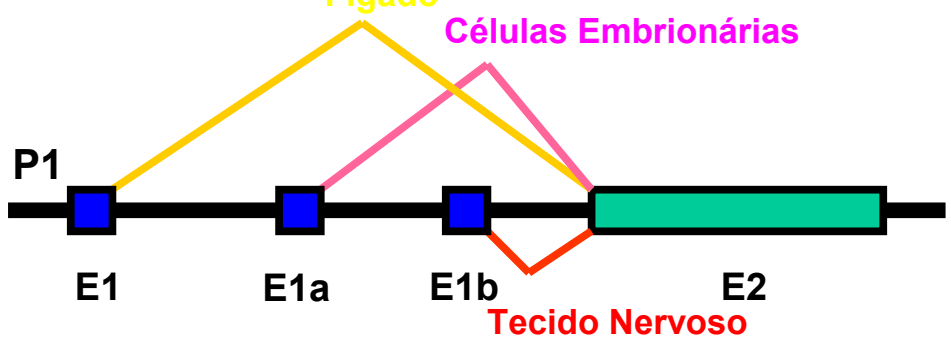

C

Fígado, rins, útero, intestino, testículo, ovários, pâncreas.

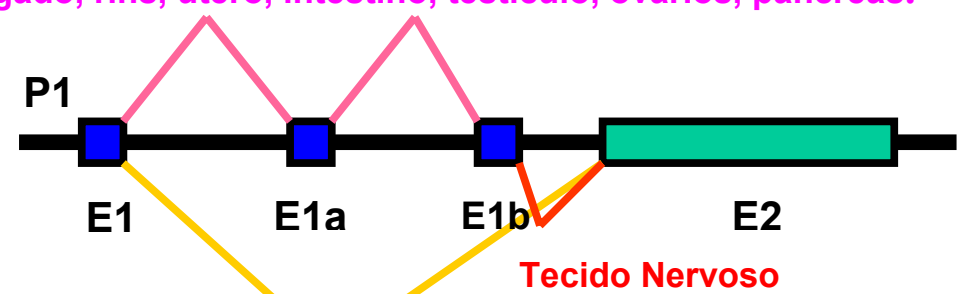

Figura 7 - Organização das regiões reguladoras do gene da Cx32 humano (A), murino (B) e bovino (C) (NEUHAUS, 1996; SÖHL et al., 1996, 2001; DUGA et al., 1999, respectivamente) 


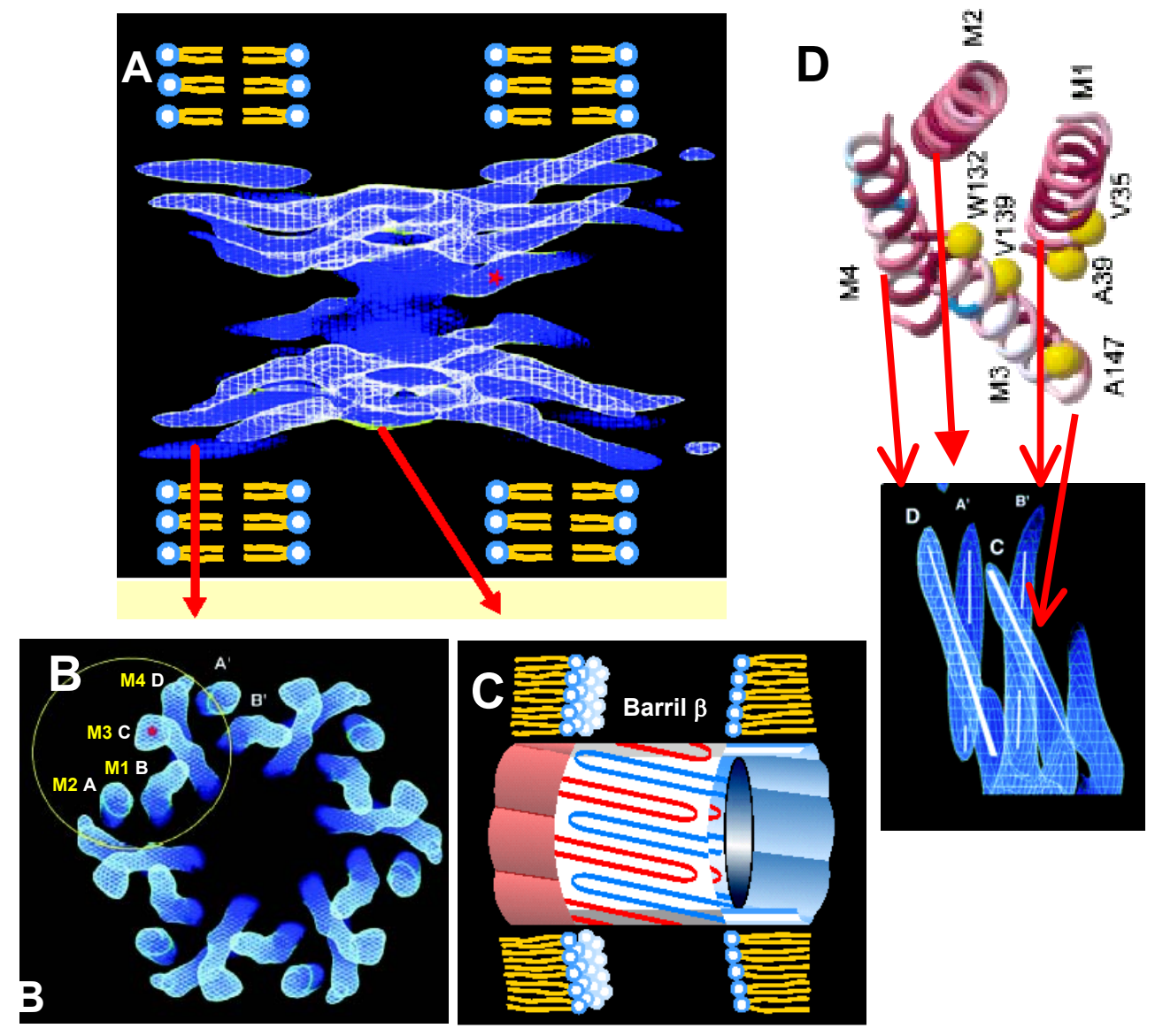

Figura 8 - Representação do canal juncional formado pela Cx43 (UNGER et al., 1999). A. Canal completo visto em corte longitudinal, * representa o domínio M3 no centro do poro. A organização do domínio citoplasmático (B) $\alpha$-hélice vista de cima com seus domínios recentemente descritos em $\mathbf{D}$, mostrando os domínios $M 1$ e M3 linearizando o poro central (FLEISHMAN et al., 2004). C. Modelo de organização do barril ( das alças extracelulares de Cxs pertencentes a dois conexons associados. $A=M 2 ; B=M 1 ; C=$ M3; $\mathrm{D}=\mathrm{M} 4$ 


\subsection{O CANAL JUNCIONAL PROPRIAMENTE DITO}

\subsubsection{Estrutura do canal juncional}

Como já mencionado, as Cxs, oligomerizadas em conexons, se associam visà-vis com um conexon fornecido pela célula vizinha para formar um canal juncional completo. Cada canal é composto pela associação de 12 moléculas de Cx ao redor de um poro central (MAKOWSKI et al., 1977; UNGER et al., 1999). Unger et al. 1999 propuseram recentemente um modelo de organização molecular representado na figura $8 \mathrm{~A}$ e que completa o modelo anterior descrito por Milks. Segundo Milks (MILKS et al., 1988) os quatro segmentos transmembra de cada conexina seriam dispostos em losango, com M3 margeando o poro do canal. Após as análises de Unger, 2 segmentos transmembra em (-hélice contribuiriam para a função do poro juncional (Figura $8 \mathrm{AB}$ ). Os potencias candidatos a compor à parede do canal eram M3, devido a sua estrutura em (-hélice e sua composição anfipática, e M1 após experimentos de mutagênese dirigida contra esta região (BENNETT et al., 1991; UNWIN, 1989; ZHOU et al., 1997). Em setembro de 2004 (FLEISHMAN et al., 2004) foram demonstradas experimentalmente as posições dos resíduos de aminoácido presentes em cada $\alpha$-hélice das conexinas. Tais experimentos provaram que os domínios M1 e M3 linearizam a face central do poro das junções gap (Figura 8 D). Além disso, ficou claro que as $\alpha$-hélice $M 1$ e M2 são mais sensíveis às mutações que as M3 e M4; evidenciando o fato de mutações características a algumas síndromes (Charcot-Marie-Tooth e surdez e doenças da pele) estarem associadas aos domínios M1 e M2. Estas mutações provocariam uma maior compactação 
destas duas $\alpha$-hélice impedindo a passagem de moléculas essenciais de uma célula à outra.

Aparentemente, a região do contato entre os dois conexons de duas células vizinhas se faz através de alças que constituem cada conexina. Segundo Foote et al. (1998) as alças E1 e E2 estariam organizadas em folhas $\beta$ antiparalelas produzindo inter-digitações ligeiramente inclinadas em relação ao plano perpendicular da membrana plasmática, formando um "barril $\beta$ " (Figura $8 \mathrm{C}$ ). Além disso, através da interação entre os dois conexons, estes seriam deslocados uns em relação aos outros em um ângulo de rotação de $30^{\circ}$ ao redor do eixo central. Isto contribuiria para assegurar um encaixe perfeito do canal juncional em relação ao meio extracelular (Figura 8C) (PERKINS et al., 1998; YEAGER; NICHOLSON, 1996). Estas interações conexon a conexon interfeririam com numerosas ligações de hidrogênio, o que explicaria a necessidade de se utilizar condições drásticas para dissociar as membranas das células adjacentes no nível de placa juncional.

\subsubsection{Montagem dos conexons}

Uma das principais contribuições no domínio da JG no transcorrer dos últimos anos foi à demonstração de que diferentes conexinas poderiam estar implicadas na formação de um mesmo canal.

Como ilustrado na figura 9, diz-se que um conexon é homomérico se ele é composto de um único tipo de conexina ou que ele é heteromérico se ele é composto por diferentes tipos de conexinas. Por sua vez, os canais intercelulares podem ser constituídos a partir de combinações diferentes de conexons homoméricos ou heteroméricos. A associação de dois conexons idênticos leva a 
formação de um canal homotípico enquanto que o alinhamento de dois conexons diferentes forma um canal heterotípico.

A existência de conexons heteroméricos foi observada in vitro e confirmada in vivo. Diferentes combinações foram descritas: Cx32/Cx26 no fígado (DIEZ et al., 1999) e na glândula mamária (Berthoud et al., 2000), Cx40/Cx43 no músculo liso (HE et al., 1999). Ou ainda Cx45,6/Cx50 no cristalino (JIANG; GOODENOUGH, 1996). Hoje em dia, a existência in vivo de canais heterotípicos formados de conexons heteroméricos ainda não foi demonstrado (YEAGER et al., 1998). 


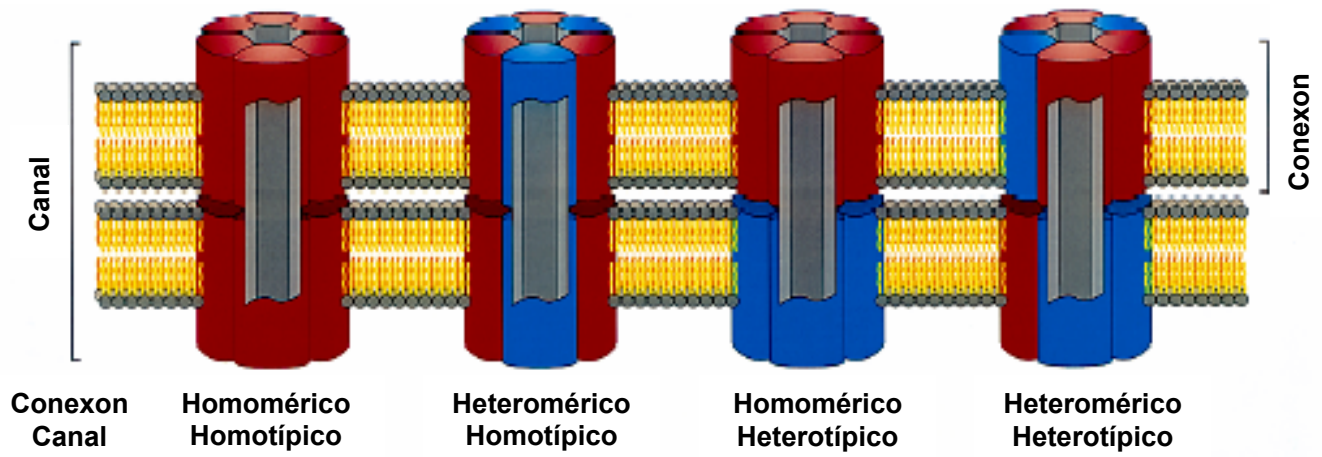

Figura 9 - llustração apresentando as possibilidades de associação das conexinas em um conexon e dos conexons em um canal juncional (KUMAR; GILULA, 1996). Este exemplo simplificado apresenta apenas duas conexinas (azul e vermelha). Os conexons podem ser homoméricos (formados de seis conexinas idênticas) ou heteroméricos (composto de diferentes conexinas). Os canais podem ser homotípicos (composto de dois conexons idênticos) ou heterotípicos (formados por dois conexons diferentes) 
Tabela 3 - Compatibilidade entre Cx para a formação de canais juncionais heterotípicos

\begin{tabular}{|c|c|c|}
\hline \multirow{2}{*}{ Conexina } & \multicolumn{2}{|c|}{ Combinação } \\
\hline & Funcional & Não Funcional \\
\hline 26 & $26,32,46,50$ & $31,31.1,37,40,43,45$ \\
\hline 30,3 & 30,3 & n.t. \\
\hline 31 & 31 & $26,32,37,40,43,45$ \\
\hline 31,1 & $?$ & $26,31.1,32,43$ \\
\hline 32 & $26,32,46,50$ & $31,37,40,43,45$ \\
\hline 33 & $?$ & $33,37,43$ \\
\hline 37 & $37,40,43,45$ & $26,31,32,33$ \\
\hline 40 & $37,40,45$ & $26,31,32,43,46,50$ \\
\hline 43 & $37,43,45,46$ & $26,31,32,33,40,50$ \\
\hline 45 & $37,40,43,45$ & $26,31,32$ \\
\hline 46 & $26,32,43,46,50$ & 40 \\
\hline 50 & $26,32,46,50$ & 40,43 \\
\hline
\end{tabular}

Resumo dos estudos de compatibilidade de conexons homoméricos para a formação de canais heterotípicos (BRUZZONE et al., 1996). Caracteres em preto representam as configurações testadas em células de HeLa transfectadas com o cDNA das conexinas de interesse (ELFGANG et al., 1995). Os caracteres em azul representam as configurações testadas em oócitos de Xenopus micro injetados com os mRNA das conexinas de interesse (BRUZZONE et al., 1993;HENNEMAN et al., 1992, 1992b; WHITE et al., 1994, 1994b e 1995). Os caracteres em vermelho representam as configurações testadas em dois tipos de preparações. Os testes de funcionalidade estão baseados na medida da corrente juncional pelo método de dupla voltagem clamp e/ou pela medida da difusão do pigmento fluorescente amarelo de Lúcifer micro injetado. n.t. não testado. 
Estudos funcionais a partir de células de mamíferos ou de oócitos de Xenopus transfectados com cDNA de diferentes Cx formando canais heterotípicos mostraram que estes têm propriedades diferentes em relação aos canais homotípicos formados de conexons homoméricos (BEVANS et al., 1998; BRINK et al., 1997; HE et al., 1999).

Além disso, este estudo provou a existência de incompatibilidade funcional entre determinados tipos de conexons. A tabela 3 recapitula estes dados. É preciso notar que conexinas incompatíveis na formação de canais heterotípicos podem se associar para formar conexons heteroméricos, como é o caso das Cx40 e Cx43 para os quais a associação é impossível, mas a associação paralela é possível (HAUBRICH et al., 1996; HE et al., 1999). Entretanto, a associação entre as Cx32 e Cx43 é impossível nos dois sentidos (FALK et al., 1997).

Vários sinais localizados na seqüência peptídica das Cx parecem regular a montagem das conexinas. As regiões do domínio carboxi terminal e das alças E1 e E2 das Cxs são importantes para a interação conexon/conexon (HAUBRICH et al., 1996; WHITE et al., 1995). Enquanto que as regiões dos domínios amino terminal, M1 e E1 parecem desempenhar uma função na interação das conexinas dentro do conexon (FALK et al., 1997).

Admite-se atualmente que a não funcionalidade de determinados canais heterotípicos poderia desempenhar uma função no funcionamento de certos órgãos, estabelecendo barreiras de comunicação fisiológica entre determinados grupos de células. 


\subsection{DINÂMICA DE FORMAÇÃO E DEGRADAÇÃO DAS PLACAS JUNCIONAIS}

As diferentes etapas envolvidas na síntese, na montagem e na degradação das conexinas e das JG estão representadas na figura 10.

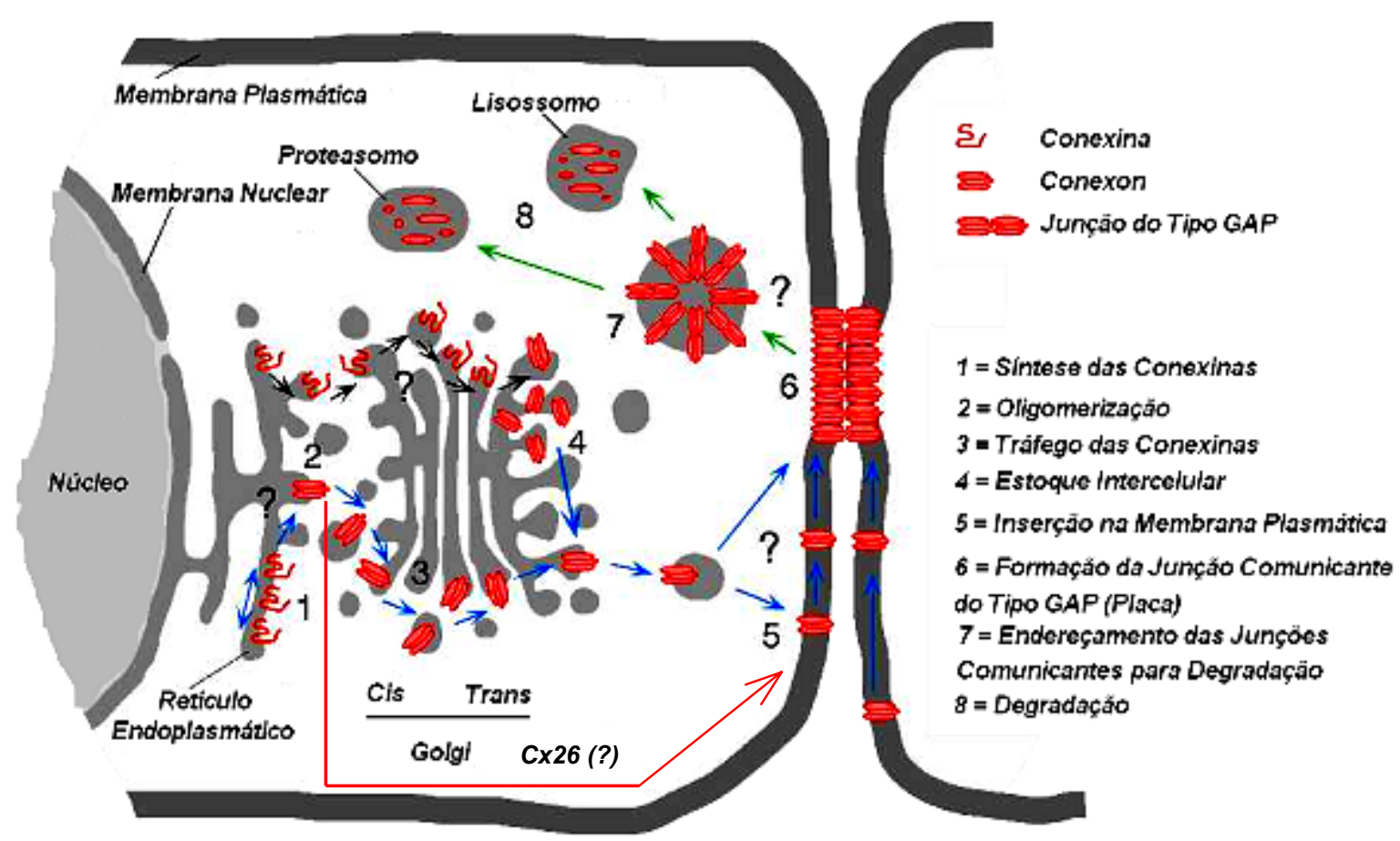

Figura 10 - Representação esquemática da síntese, montagem e da degradação dos canais membranares das junções gap. As flechas azuis representam o caminho percorrido pelas conexinas durante a síntese, de sua montagem no retículo endoplasmático e do transporte dos conexons do Golgi até a membrana plasmática. As flechas pretas representam o transporte das conexinas ainda não montadas pela face trans do aparelho de Golgi. A flecha vermelha indica a possível via de endereçamento da Cx26 à membrana. As flechas verdes ilustram as vias de degradação dos canais das junções do tipo gap. (YEAGER et al., 1998). Cx26(?): ainda há dúvidas sobre a existência desta via 


\subsubsection{Biosíntese das Cxs e montagem das junções gap}

Com algumas exceções, as proteínas das membranas plasmáticas são sintetizadas pela via clássica de biosíntese de proteínas secretadas (PFEFFER; ROTHMAN, 1987). Isto também se aplica as Cxs com algumas particularidades.

O estudo da síntese das conexinas, de início, foi realizado in vitro em presença de lisados celulares adicionados a vesículas derivadas do retículo endoplasmático (RE) ou microssomo. Este sistema permite seguir a integração de proteínas na membrana do RE. Outra técnica consiste em detectar as conexinas através de western blot nos diferentes compartimentos sub-celulares obtidos após um fracionamento realizado a partir de células em cultura ou de tecidos. Recentemente, o estudo do tráfego intracelular das Cxs conheceu sua revolução graças à utilização das proteínas fluorescentes como as Green Fluorescent Protein (GFP), que fusionadas a região carboxi terminal das Cxs, permite seguir a expressão da proteína quimera Cx/EGFP in situ na célula viva.

As conexinas são sintetizadas no RE por um processo que implica no reconhecimento e no endereçamento das Cxs em direção a membrana do RE (FALK; GILULA, 1998). Contrário a numerosas proteínas de membrana, as Cxs não possuem peptídeo sinal. Algumas vezes, na sua parte $\mathrm{N}$-terminal, as Cxs possuem seqüências muito conservadas de resíduos não polares separados por grupos de aminoácidos variáveis que poderiam desempenhar esta função. Além disso, o primeiro segmento transmembrana (M1) poderia preencher esta lacuna no endereçamento da proteína para a membrana. No curso de sua tradução, as cadeias polipeptídicas das Cxs em elongação adquirem sua estrutura secundária e são integradas de maneira co-transducional na membrana do RE onde elas adotam 
sua topologia final (extremidades N-e C-terminal citoplasmática e alças extracelulares orientadas em direção à luz do RE). É nesta etapa que as pontes de dissulfeto são formadas (RAHMAN et al., 1993) (Figura 10 etapa 1).

Numerosos estudos mostraram que no transcorrer de sua síntese, as Cxs e em particular as Cxs32 e 43 transitam pela via "golgeana" (FALK; GILULA, 1998; LAIRD et al., 1995; MUSIL; GOODENOUGH, 1993;) (Figura 10). A Cx26 por sua vez toma uma via mais rápida, não envolvendo o Golgi. Ela seria endereçada à membrana plasmática após sua saída do RE (Figura 10 flecha vermelha) (DIEZ et al., 1999; GEORGE et al., 1999). Esta via envolvendo a Cx26 ainda é discutível e parece ser impossível (Dr. Francisco J. H. Blazquez, FMVZ-USP, informação verbal) ${ }^{1}$.

O local de oligomerização das Cxs em conexons é um assunto de controvérsia. Dois locais potenciais foram descritos. Musil e Goodenough mostraram que o local de oligomerização das Cxs se passaria numa região distal do trans-Golgi (MUSIL; GOODENOUGH, 1993). (Figura 10, flechas pretas). Isto seria um caso particular para as Cxs, uma vez que para as outras proteínas oligoméricas, a montagem se passa no RE. Mais tarde, outras observações evidenciaram que esta etapa se realiza acima de tudo no RE igualmente para as conexinas. Assim, Kumar et al. (1995) colocaram em evidencia a existência de estruturas pentalaminares das membranas do RE derivadas de células que superexpressam uma Cx (KUMAR et al., 1995); e mais recentemente os trabalhos de George et al. sugeriram que a oligomerização se passaria em uma região especializada do RE, os CIREG (compartimentos intermediários entre o RE e o Golgi) (GEORGE et al., 1999; FALK et al., 1997) (Figura 10 flechas azuis). 
O modo de formação das placas juncionais, isto é, como os conexons chegam até a membrana plasmática e como elas se reagrupam para formar a placa juncional não é tão claro (Figura 10 etapa 5). Duas hipóteses possíveis foram formuladas: a) os conexons podem ser transportados diretamente em direção a um local juncional onde eles reencontram os conexons de uma célula vizinha; ou b) os conexons são inseridos na membrana plasmática onde eles ficam sob a forma de hemicanal e reencontram ao acaso o conexon da célula vizinha, e se deslocam sob a forma de canal, já pronto, até o local juncional por meio de movimentos laterais na bicamada lipídica. Dados recentes obtidos pela visualização de placas juncionais formadas a partir de proteínas quimeras Cx/GFP, assim como a presença de conexons isolados da membrana plasmática de locais não juncionais, são a favor da segunda hipótese (FALK, 1998; LI et al., 1996; QUIST et al., 2000). As moléculas de adesão celular como a caderina $E$ facilitariam a interação de hemicanais de células adjacentes e desempenhariam uma função na formação das placas juncionais (FUJIMOTO et al., 1997; JONGEN et al., 1991; MEYER et al., 1992). Além disso, o fato da possível interação descrita entre algumas Cxs (Cx32 ou Cx43) com proteínas de junção compacta como ZO1 ou as ocludinas (GIEPMANS et al., 1998; KOJIMA et al., 1999; TOYOFUKU et al., 1998), as JG poderiam se formar nas regiões específicas da membrana plasmática como é o caso de células polarizadas nas quais as JG são colocalizadas com junções compactas (GUERRIER et al., 1995). 

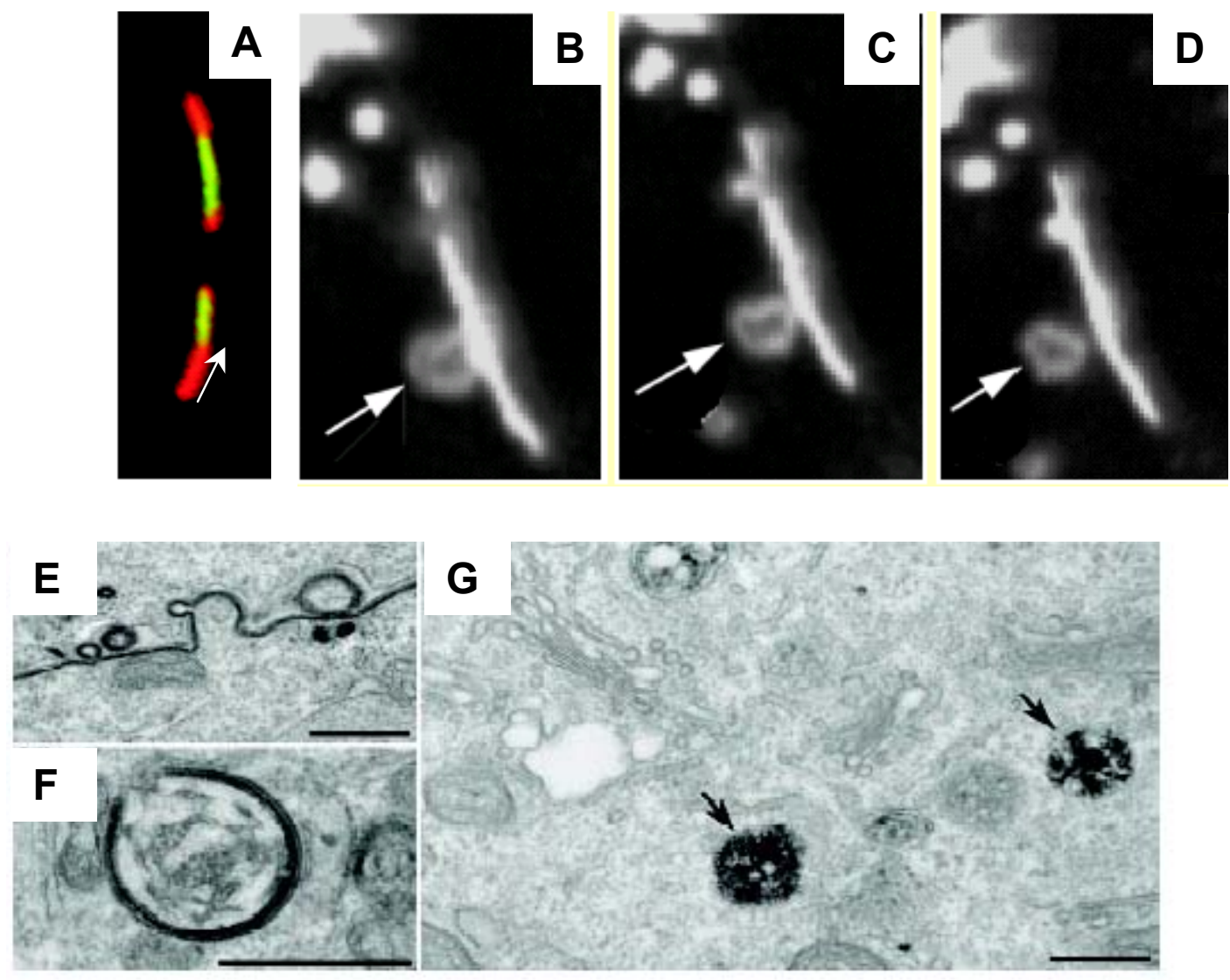

Figura 11 - Visualização das Junções Gap anulares. A Biosíntese. Conexinas recentemente sintetizadas (vermelho) são adicionadas na periferia de placas pré-existentes (verde); a seta branca mostra a direção. B Degradação. Em pouco mais que 2 minutos a porção da placa constituída de Cx43 é internalizada como uma junção gap anular, flechas brancas (JORDAN et al., 2001). C.D.E.F.G. Visualização da junção anular e vesícula de degradação. Barra $=0,5 \mu \mathrm{m}$ 


\subsubsection{Degradação das conexinas}

As conexinas apresentam uma meia vida variando de 1,5 a 5 horas segundo a conexina e o tipo celular considerado. Por outro lado, excepcionalmente, a conexina 46 apresenta a maior meia vida entre as conexinas já estudadas quanto a este assunto, ou seja, superior a 24 horas (JIANG et al., 1993). No entanto, para a maioria das conexinas isto é muito curto quando se levam em consideração as junções compactas e os desmossomos que têm uma meia vida de 24 horas (DARROW et al., 1995; LAIRD et al., 1995; 1991; MUSIL et al., 1990; TRAUB et al., 1987). A observação das junções gap formadas por Cx/GFP em células em cultura que elas são estruturas que estão em constante movimento (Figura 11A). Elas se dividem e se fusionam constantemente (FALK, 2000).

Estudos de microscopia eletrônica com células que super-expressam conexinas ou em tecidos mostrou a presença no citoplasma de estruturas vesiculares ricas em $\mathrm{Cx}$, apresentando um perfil pentalaminar semelhante ao das junções intercelulares (LARSEN et al., 1979; NAUS et al., 1993; SEVERS et al., 1989). Estas estruturas chamadas "junções anulares" são oriundas da internalização de parte ou da totalidade de uma placa juncional por uma das células em contato (Figura 11B, C e D). Isto é devido a forte interação conexon-conexon no espaço intercelular que os impedem de se dissociar, obrigando-os a se internalizar sob a forma de um canal completo (GHOSHROY et al., 1995; GOODENOUGH; GILULA, 1974). Jordan et al. seguiram a formação das junções anulares em células transfectadas com o cDNA da conexina 43 fusionada à GFP (Figura 11B). Estas observações confirmaram que estas estruturas são provenientes da internalização de placas juncionais da membrana citoplasmática. 
As últimas etapas da degradação das JG não são bem entendidas até o presente momento. A degradação das conexinas engloba a via dos lisossomos e a dos proteasossomos (Figura 10, etapa 8) (LAING et al., 1995; 1997; MUSIL et al., 2000; RAHMAN et al., 1993). Do mais, graças aos sistemas de "controle de qualidade" das células, as conexinas incorretamente replicadas ou oligomerizadas são seletivamente conduzidas para a saída do retículo endoplasmático, via proteasosssomos ou endossomos, para lá serem degradados (HAMMOND; HELENIUS, 1995; VANSLYKE et al., 2000a). 


\subsection{A COMUNICAÇÃO INTERCELULAR VIA JUNÇÕES DO TIPO GAP}

\subsubsection{Propriedades dos canais juncionais}

\subsubsection{Definição da permeabilidade juncional}

Há muito tempo foi estabelecido que as Cxs, organizadas ao redor do poro hidrofílico (10 a 20 Á de diâmetro, Figura 2) permite a troca direta entre os citoplasmas de células adjacentes de moléculas hidrofílicas de tamanho inferior a 1000 Da (SCHWARZMANN et al., 1981; SIMPSON et al., 1977). Estes dados permitem presumir a possibilidade da troca de moléculas biológicas importantes para o metabolismo celular. Efetivamente, foi mostrado que as JG permitem a passagem de íons $\left(\mathrm{K}^{+}, \mathrm{Cl}^{-} \ldots\right)$, mensageiros secundários (AMPc, IP3, $\mathrm{Ca}^{+2}$ ), nucleotídeos (ADP, ATP, CTP) e determinados compostos do metabolismo intermediário (aminoácidos, oses, ...) (CHARLES et al., 1992; GOLDBERG et al., 1998; MUNARI-SILEM et al., 1995; SAEZ et al., 1989;). As moléculas maiores como os ácidos nucléicos, as proteínas e os lipídeos não passam pelo canal juncional.

Experimentalmente, a união via JG entre duas células pode ser avaliado por: 1) medida da transferência entre as células adjacentes de pequenas moléculas fluorescentes microinjetadas ou literalmente cortadas (como a técnica que usamos nesta tese, ver M\&M) no citoplasma de uma célula, a qual não atravessa a membrana citoplasmática; 2) medida da passagem de corrente elétrica entre duas células vizinhas, atestando para a transferência de íons de célula a célula via JG; 3) a medida da cooperação metabólica entre as células pode ser acompanhada através de seu efeito na célula vizinha (MUNARI-SILEM et al., 1995). 
Os primeiros estudos visando caracterizar os canais do tipo gap e em particular determinar sua permeabilidade foram realizados sobre modelos celulares os quais não se conheciam as composições das conexinas presentes. Após a clonagem dos genes das conexinas, dois modelos experimentais foram desenvolvidos: 1) os oócitos de Xenopus colocados lado a lado nas quais os cRNA das conexinas foram injetados. Estas células expressam endogenamente a Cx38, os RNA antisenso da Cx38 são injetados para bloquear sua expressão. Este sistema é utilizado, sobretudo para a determinação das propriedades elétrofisiológicas dos canais juncionais - Duo PatchClamp (DAHL et al., 1987); 2) linhagens celulares com comunicação deficiente, que não expressam $\mathrm{Cx}$ endogenamente (ou cuja composição da Cx presente seja conhecida), nas quais as conexinas exógenas são expressas após transfecção do cDNA da conexina desejada. Este sistema permite estudar as propriedades das JG, desde o tipo de molécula trocada até o impacto do restabelecimento da comunicação intercelular sobre a atividade das células, a proliferação celular ou a diferenciação celular (Tabela 9).

\subsubsection{Noção de permeabilidade seletiva}

Após os anos 70, numerosos estudos mostraram, por meio de medida de transferência de sondas fluorescentes de propriedades variáveis, que seguem as Cxs implicadas na formação do canal juncional, a permeabilidade depende do tamanho, da forma e da carga das moléculas trocadas (ELFGANG et al., 1995; KANNO; LOEWENSTEIN, 1966; NICHOLSON et al., 2000; STEINBERG et al., 1994; VEENSTRA et al., 1994;). 
Quanto à permeabilidade dos canais juncionais a moléculas biológicas, poucos estudos foram realizados. Brissette et al., demonstraram que durante a diferenciação dos queratinócitos, a inversão na expressão de Cxs acompanha uma inversão de permeabilidade juncional nestas células (BRISSETTE et al., 1994). Este estudo sugeriu pela primeira vez que a natureza dos metabólitos biológicos compartilhados pelas células poderia variar de acordo com o tipo de Cx presente. Mais tarde, Bevans et al. (1998) mostraram, em estudos de propriedades juncionais de JG reconstituídas em lipossomos, que os canais formados pela Cx32 apresentavam a mesma permeabilidade vis-à-vis ao AMPc e ao GMPc. Porém, as JG formadas por canais heteroméricos Cx32/Cx26 eram impermeáveis ao GMPc e fracamente permeáveis ao AMPc.

Afim de realmente identificar as moléculas biológicas trocadas através das JG, Goldberg et al. elaboraram uma técnica que permitia a captura, a identificação e a quantificação de tais metabólitos (GOLDBERG et al., 1995). Em seus estudos foram utilizados células C6 de glioma de rato que expressavam de maneira estável a Cx32 ou Cx43 (BOND et al., 1994; ZHU et al., 1991; Tabela 9). Seus resultados colocaram em evidência a passagem de quatro metabólitos abundantes trocados entre as células via JG que são o ATP, o ADP, o glutamato e o glutation (GOLDBERG et al., 1998; 1999). Foi mostrado também, que as células que expressavam a $\mathrm{Cx} 32$, tinham maior capacidade que as que expressavam a $\mathrm{Cx} 43$ de trocar calceína. E; tanto o ATP quanto o ADP, passavam dez vezes mais rápido via canal formado pela Cx32.

Recentemente, Niessen et al. (2000) mostraram que, a partir de células de HeLa transfectadas com o cDNA das Cx43, Cx32 e Cx26, o IP3 apresenta diferentes permeabilidades entre os diferentes canais formados. As JG formadas pela Cx32 
são de 3 a 4 vezes mais permeáveis ao IP3 que as JG constituídas pela Cx26 e cerca de 2,5 vezes mais que os da Cx43. 
A

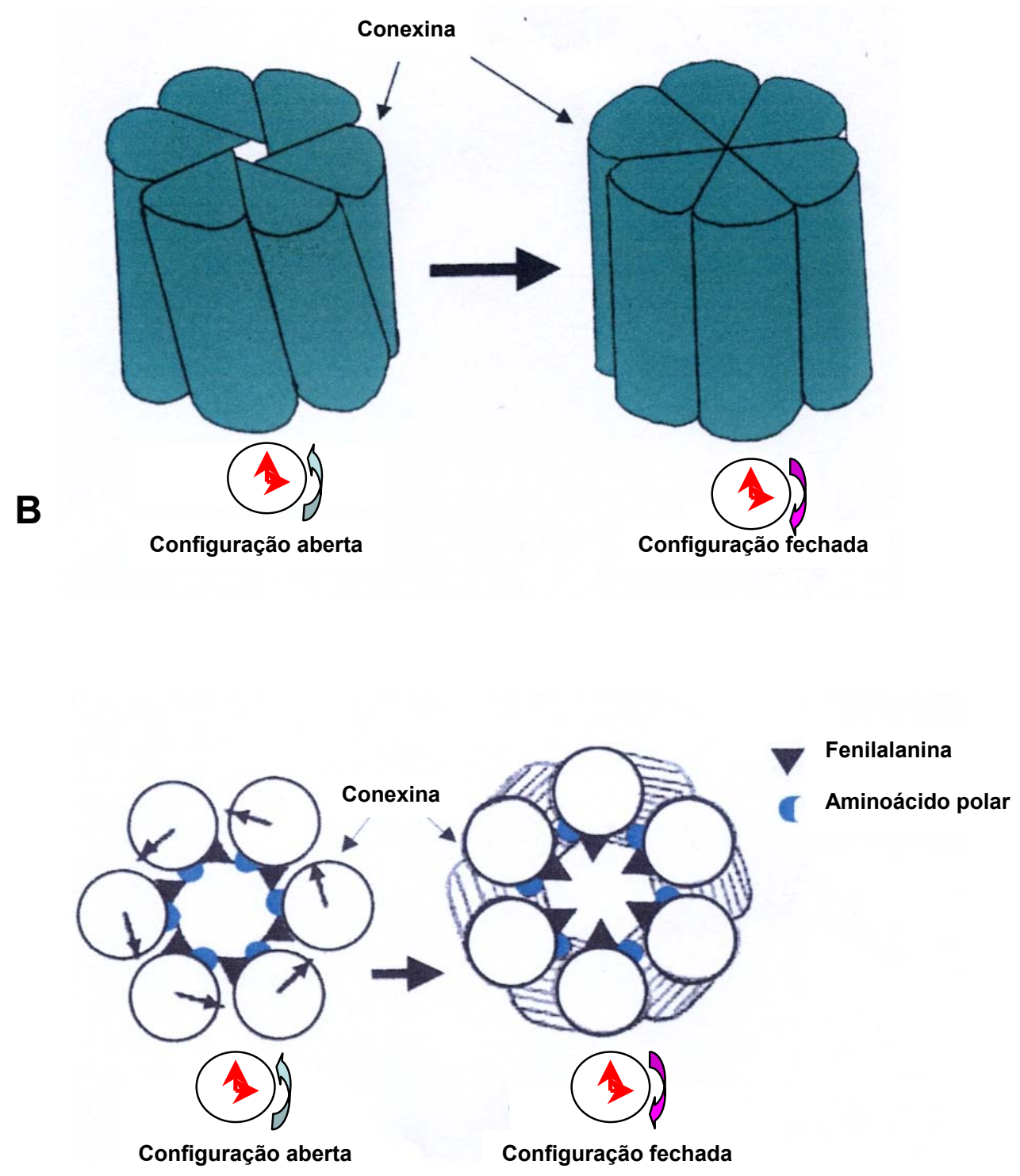

Figura 12 - Modelos propostos por Unwin et al., 1980 (A) e Unwin, 1989 (B). A: Neste modelo, a alteração na conformação aberta para fechada dos canais é efetuada por rotação dos hexâmeros no sentido dos ponteiros de um relógio, provocando dessa forma um deslizamento dos monômeros uns sobre os outros levando ao fechamento do poro. B: A inclinação do segmento M3 retira os grupamentos polares da luz do poro ao mesmo tempo em que grupamentos fenilalanina obstruem o poro 


\subsection{MODULAÇÃO DA MONTAGEM DOS CANAIS INTERCELULARES}

A comunicação intercelular via JG é regulada em diferentes níveis por mecanismos que implicam ou não na variação do conteúdo intracelular de Cx. Nas células da maioria dos tecidos, a montagem do canal intercelular é modulada em resposta a fatores extrínsecos ou intrínsecos que induzem uma modificação dos níveis de transcrição dos genes das conexinas ou sua degradação, num processo que leva horas. A montagem do canal intercelular pode ser igualmente modulada por processo mais rápido, questão de minutos, por mecanismos que induzem diretamente a abertura ou o fechamento dos canais ou "gating".

O gating é definido como a transição entre as conformações abertas ou fechadas dos canais juncionais. Após 1979, as variações no tamanho do poro observado em microscópio eletrônico em relação às variações no nível de comunicação sugeriram a Zampighi e Unwin em 1979 que os canais poderiam estar abertos ou fechados (ZAMPIGHI; UNWIN, 1979). Eles propuseram mais tarde um modelo no qual a transição de um estado ao outro é efetuado pela torção dos hexâmeros no sentido dos ponteiros de um relógio. Este movimento está associado ao deslizamento dos monômeros um em relação aos outros (Figura 12A) (UNWIM; ZAMPIGHI, 1980). Este modelo foi completado levando-se em conta a topologia e a composição dos aminoácidos das Cx: quando do fechamento dos canais, a inclinação do segmento M3 retiraria os grupamentos polares da luz do canal e os substituiria pelos volumosos resíduos de fenilalanina. Estes últimos obstruiriam a luz do canal por preenchimento etéreo (Figura 12B) (UNWIN, 1989).

A regulação da abertura e do fechamento dos canais juncionais se faz em questão de segundos. Esta regulação pode ocorrer em resposta às modificações do 
ambiente intracelular como o pH ou a concentração de $\mathrm{Ca}^{+2}$ (LIU et al., 1993; MORLEY et al., 1996; PERACCHIA et al., 2000; SPRAY; BURT, 1990; WANG; PERACCHIA, 1996;) e também pela influência de diferentes proteínas cinases. As tabelas 4 e 5 agrupam as informações sobre a fosforilação de algumas Cxs e sobre o impacto da ativação das proteínas cinases sobre a comunicação juncional. 
Tabela 4 - Conexinas: substratos de fosforilação

\begin{tabular}{|c|c|c|c|}
\hline Conexina & $\begin{array}{l}\text { Aminoácido } \\
\text { fosforilado }\end{array}$ & $\begin{array}{c}\text { Proteína } \\
\text { Cinase }\end{array}$ & Referência \\
\hline Cx31 & n.d. & n.d. & TRAUB et al., 1995 \\
\hline \multirow[t]{4}{*}{$\mathrm{C} \times 32$} & Ser 233 & PKA, PKC & \\
\hline & Thr n.d. & $\mathrm{Ca}^{+2}-\mathrm{CM}$ dPKII & SAEZ et al., 1989 \\
\hline & Ser n.d. & PKA, PKC & \\
\hline & Tyr 7 e/ou 243 & R-EGF-TK & DIEZ et al., 1995 \\
\hline Cx40 & n.d. & n.d. & TRAUB et al., 1994 \\
\hline \multirow[t]{6}{*}{$\int \mathrm{Cx} 43$} & Ser 255, 279, 282 & MAPK, p34 ${ }^{\mathrm{cdc} 2}$ & $\begin{array}{l}\text { WARN-CRAMER et al., } \\
\text { 1996, } 1998\end{array}$ \\
\hline & Ser 368,372 & & KANEMITSU et al., 1998 \\
\hline & Tyr 247, 265 & PKC & \\
\hline & & $\mathrm{pp} 60^{\mathrm{v}-\mathrm{src}}$ & SAEZ et al., 1997 \\
\hline & & & LO et al., 1996 \\
\hline & & & LAU et al., 1996 \\
\hline Cx45 & n.d. & n.d. & LAING et al., 1994 \\
\hline Cx45.6 & n.d. & $\mathrm{Mg}^{+2}-\mathrm{dPK}$ & ARNESON et al., 1995 \\
\hline Cx46 & n.d. & n.d. & JIANG et al., 1996 \\
\hline Cx50 & n.d. & $\mathrm{Mg}^{+2}-\mathrm{dPK}$ & ARNESON et al., 1995 \\
\hline Cx56 & Ser 118, 493 & PKA & BERTHOUD et al., 1997 \\
\hline
\end{tabular}

PKA: proteína cinase dependente de AMPc; PKC: proteína cinase dependente de DAG; R-EGFTK: tirosina cinase do epidermal growth factor; $\mathbf{C a}^{+2}-\mathbf{C M}$ dPKII: proteína cinase dependente do complexo $\mathrm{Ca}^{+2} /$ Calmodulina tipo II; pp60-src: tirosina cinase codificada pelo oncogene v-src; MAPK: mitogen activated protein cinase (SAEZ et al., 1997) 
Tabela 5 - Efeito da ativação das proteínas cinases sobre a comunicação mediada pelas JG

\begin{tabular}{|c|c|c|c|}
\hline $\begin{array}{l}\text { Proteína } \\
\text { Cinase }\end{array}$ & Tipo celular & Comunicação & Referência \\
\hline$\lambda$ & Hepatócitos & & SAEZ et al., 1986 \\
\hline \multirow{2}{*}{$\leadsto$} & & & TRAUB et al., 1987 \\
\hline & Miócitos cardíacos & & BURT; SPRAY 1988 \\
\hline \multirow[t]{3}{*}{ RKA } & Células do miométrio & & COLE; GARFIELD 1986 \\
\hline & Células de Sertoli & & GRASSI et al., 1986 \\
\hline & $\begin{array}{c}\text { Células horizontais } \\
\text { (retina) }\end{array}$ & & $\begin{array}{c}\text { DEVRIES; SCHWARTZ, } \\
1989\end{array}$ \\
\hline$\lambda$ & Células de Sertole & & GRASSi et al., 1986 \\
\hline \multirow[t]{2}{*}{$\mathrm{PKC}$} & Miócitos cardíacos & & SPRAY; BURT, 1990 \\
\hline & Hepatócitos & $?$ & \\
\hline \multirow{2}{*}{ AKG } & Miócitos cardíacos & & BURT, SPRAY, 1988 \\
\hline & Células horizontais & & $\begin{array}{c}\text { DEVRIES; SCHWARTZ, } \\
1989\end{array}$ \\
\hline $\begin{array}{l}\text { Tirosina } \\
\text { Cinlase }\end{array}$ & Fibroblastos & & CROW et al., 1990 \\
\hline
\end{tabular}

PKA: proteína cinase dependente de AMPc; PKC: proteína cinase dependente de DAG; PKG: proteína cinase dependente de GMPc. (BENNET et al., 1991) 


\subsection{IMPLICAÇÕES FISIOLÓGICAS DAS JUNÇÕES DO TIPO GAP}

\subsubsection{Da difusão de moléculas à harmonização das funções fisiológicas}

De um modo geral, as JG permitem a harmonização e a sincronização das atividades celulares. Nas células excitáveis, está estabelecido que elas permitam a troca de íons, são as origens da sincronização das atividades elétricas. Por exemplo, nos cardiomiócitos, as JG mantêm a sincronização dos batimentos cardíacos e nos neurônios, asseguram a coordenação da resposta aos estímulos centrais. No cérebro, a comunicação via JG seria mais rápida que aquelas fornecidas pelas sinapses químicas.

As JG também desempenham uma importante função na regulação da homeostasia tecidual, isto é, na manutenção das constantes fisiológicas $(\mathrm{pH}$, concentrações iônicas) a um nível de equilíbrio de uma dada população celular (LOESWENSTEIN; KANO, 1966).

As JG são, sobretudo, os suportes das trocas metabólicas que ocorrem entre as células e é admitido atualmente participar de processos como:

- A nutrição de órgãos pobremente vascularizados tais como o cristalino (GOODENOUGH et al., 1980) através da passagem de pequenos metabólitos (oses, aminoácidos, nucleotídeos). Ao contrário, no fígado, as JG permitem a diluição de compostos tóxicos conectando a maior parte das células.

- A correção de defeitos somáticos. Por exemplo, mostrou-se que células contendo mutação que inativa o gene que codifica para a hipoxantinaguanina-fosforibosil-transferase (enzima que atua na via da biosíntese das purinas) adquirem um fenótipo normal quando são co-cultivadas com células 
do mesmo tipo, sem a mutação. A transferência do nucleotídeo que falta, ou de um de seus derivados, via JG a partir das células normais para as células mutantes, seria a origem desta correção (PITTS; SIMMS, 1977).

- A amplificação da resposta biológica das células a um fator de sinalização. Isto significa que as células de uma via de sinalização foi ativada após a fixação de um hormônio em receptor, por exemplo, podendo transmitir o ou os mensageiros secundários $\left(\mathrm{AMPc}, \mathrm{IP} 3, \mathrm{Ca}^{+2}\right.$ ) as células vizinhas via JG. As células que não foram diretamente ativadas pelo hormônio serão ativadas pelos mensageiros secundários que é uma amplificação da resposta hormonal. Assim, foi demonstrado que nas células do córtex supra-renal bovino em cultura primária que expressam a Cx43 e apresentam canais funcionais, a quantidade de cortisol produzida em resposta a corticotropina $(\mathrm{ACTH})$, é menor quando a comunicação é inibida pelo ácido $18 \alpha$-glicérico. A transferência de AMPc via JG entre as células responsivas e não responsivas a esta concentração de ACTH poderia ser o mecanismo pelo qual as células supra-renais responderiam a baixas variações na concentração de hormônio circulante (MUNARI-SILEM et al., 1995).

As JG desempenham também uma função importante durante o desenvolvimento. Na maioria dos organismos, a comunicação intercelular via junções do tipo gap (CIJG) é observado em estágios ainda muito precoces. No camundongo, a CIJG é estabelecida após o estágio de 8 células (blástula) onde 6 genes da Cx são já transcritos (DAVIES et al., 1996). A CIJG permite a passagem de sinais envolvidos no estabelecimento de gradientes morfogênicos (GREEN 1988; LEE et al., 1987; PAUL et al., 1995). Durante o curso do desenvolvimento 
embrionário, a CIJG é restringida a determinadas regiões. Esta criação de "territórios de comunicação" é mediada de uma parte pela expressão diferencial e espaço temporal de diferentes genes de $\mathrm{Cx}$ e por outro lado, pela impossibilidade de determinadas conexinas formarem canais heterotípicos funcionais (LO, 1996).

A comunicação juncional parece estar também implicada no controle da proliferação celular e da diferenciação das células. Esta parte, por ser o foco central de minha tese, será detalhada no item 2.9.

\subsubsection{Funções das JG deduzidas de estudos de doenças genéticas e do fenótipo de camundongos knockouts para uma determinada conexina}

Apesar dos canais intercelulares já terem sido caracterizados a nível bioquímico e estrutural, poucas informações sobre seu impacto nos indivíduos estavam disponíveis nos últimos anos. A identificação das doenças genéticas hereditárias humanas associadas a mutações sobre os genes das Cx de uma parte, e o estudo do fenótipo dos camundongos knockouts para um 1 ou 2 genes de Cx, de outra, forneceram evidências de que a comunicação via JG é crucial para o desenvolvimento e funcionamento de numerosos órgãos. 
Tabela 6 - Apresentação das doenças humanas provocadas por mutações no gene das conexinas

\begin{tabular}{|c|c|}
\hline $\begin{array}{l}\text { Gene da } \\
\text { Conexina }\end{array}$ & Doença Genética no Homem \\
\hline Cx32 ${ }^{1,1011,12}$ & $\begin{array}{l}\text { Forma ligada ao cromossomo } \mathrm{X} \text { da síndrome de Charcot- } \\
\text { Marie-Tooth }\end{array}$ \\
\hline \multirow{4}{*}{ Cx26 $2,10,11,12$} & Forma recessiva da surdez não sindrômica DFN1B \\
\hline & Forma dominante da surdez não sindrômica DFNA3 \\
\hline & Síndrome de Vohwinkel \\
\hline & Queratodermia palmoplantar \\
\hline \multirow[t]{2}{*}{$\mathrm{C} \times 30^{3,4,10,11,12}$} & Forma dominante da surdez não sindrômica DFNA3 \\
\hline & Síndrome de Clouston \\
\hline Cx30.3 $3^{5,10,11,12}$ & Eritroqueratodermia variabilis (EKV) \\
\hline \multirow{3}{*}{$C \times 31^{6,7,10,11,12}$} & Eritroqueratodermia variabilis (EKV) \\
\hline & Forma recessiva da surdez progressiva não sindrômica \\
\hline & Forma dominante da surdez não sindrômica DFNA2 \\
\hline Cx46 $8,10,11,12$ & Forma hereditária da catarata CZP3 \\
\hline Cx50 9,10,11,12 & Forma hereditária da catarata CZP1 \\
\hline
\end{tabular}

1- Bergoffen et al. 1993; 2- Kelsell et al. 1997; 3- Maestrini et al. 1999; 4- Grifa et al. 1999; 5- Macari et al. 2000; 6- Richard et al. 1998; 7- Liu et al. 2000; 8- Mackay et al. 1999; 9- Shiels et al. 1998; 10White ; Paul 1999; 11- Krutovskikh ; Yamasaki, 2000; 12- Kelsell et al. 2001 


\subsubsection{1 - Doenças genéticas humanas provocadas por mutações em genes de Cx}

Várias doenças genéticas humanas estão associadas a mutações em genes que codificam para as Cxs (Tabela 6). A primeira doença genética identificada foi à doença de Chacot-Marie-Tooth associada ao cromossomo X (CMT-X), cromossomo no qual está localizada o gene da Cx32 no homem (BERGOFFEN et al., 1993). CMT-X é uma neuropatia progressiva resultante da desmielinização e degeneração dos nervos periféricos aferentes e eferentes. Hoje, mais de 160 mutações foram identificadas no gene da Cx32 em diferentes pacientes portadores da deficiência. Estas mutações estão localizadas ao longo da região codificadora do gene da Cx32 (KRUTOVSKIKH; YAMASAKI, 2000) e também em regiões não codificadoras (promotor alternativo P2). Estudos in vitro, no qual diferentes formas mutadas da Cx32 (até hoje foram testadas 27) mostraram que elas não formam canais funcionais ou que elas formam canais funcionais cuja propriedade de permeabilidade foi alterada (VANSLYKE at al., 2000b). A doença é explicada da seguinte maneira: ao nível de nervo periférico, a Cx32 é expressa nas células de Schwann e as JG-Cx32 permitem ligar diretamente o citoplasma da região periaxonal à região perinuclear da mesma célula. Esta junção dita "reflexiva" encurta a distância que os nutrientes devem percorrer para tingir o corpo celular. Alterações da capacidade de comunicação entre as células via JG constituídas de Cx32 levariam a degeneração das células de Schwann por déficit na entrega de nutrientes. De modo surpreendente, nenhuma outra patologia (câncer) foi observada em pacientes portadores destas mutações quando a Cx32 é expressa em outros tecidos e em particular o fígado. Isto é provavelmente devido ao fato da redundância funcional 
entre as conexinas, isto é, a possibilidade de outras conexinas compensarem a função da Cx mutada a nível funcional. 
Tabela 7 - Fenótipo dos camundongos cujo gene da Cx alvo foi invalidado

\begin{tabular}{|c|c|c|}
\hline Conexina & Fenótipo do camundongo & Referência \\
\hline KOCx26 & $\begin{array}{l}\text { Morte in útero entre o } 10^{\circ} \text { e o } 11^{\circ} \text { dia pós-coito; } \\
\text { Retardo no crescimento embrionário; } \\
\text { Diminuição da transferência de glicose e provavelmente outros } \\
\text { nutrientes entre o sinciotrofoblasto I e II na região conhecida como } \\
\text { labirinto da placenta. }\end{array}$ & Gabriel et al., 1998 \\
\hline KOCx31 & $\begin{array}{l}\text { Dismorfogênese placentária transitória (provavelmente compensada } \\
\text { pelo aumento de expressão da } C \times 43 \text { no } 10,5^{\circ} \text { dia). }\end{array}$ & Plum et al., 2001 \\
\hline KOCx32 & $\begin{array}{l}\text { Aumento da secreção basal de amilase pelo pâncreas exócrino pelo aumento } \\
\text { de ácinos pancreáticos; } \\
\text { Desorganização tardia da mielina periférica nos animais velhos; } \\
\text { Aumento no número de tumores hepáticos espontâneos (8 vezes a } 25 \\
\text { vezes): aumento da taxa de proliferação nos camundongos de } 1 \text { ano; } \\
\text { Aumento do número de tumores hepáticos induzidos em camundongos de } 1 \\
\text { ano; } \\
\text { Viáveis, férteis, diminuição do peso total em cerca de } 17 \% \text {; } \\
\text { Diminuição da expressão da Cx } 26 \text { nos hepatócitos; } \\
\text { Redução da mobilização de glicose hepática a partir das reservas } \\
\text { glicogênicas resultantes de um defeito de propagação dos sinais induzidos } \\
\text { pela estimulação do nervo sináptico no fígado devido à diminuição de IP3. }\end{array}$ & $\begin{array}{l}\text { Chanson et al., } \\
\text { 1998; } \\
\text { Anzini et al., 1997; } \\
\text { Teme et al., 1997; }\end{array}$ \\
\hline $\mathrm{KOC} \times 37$ & $\begin{array}{l}\text { Viáveis mas inférteis: ausência de folículos ovarianos maduros; } \\
\text { ausência de ovulação e desenvolvimento inapropriado do corpo lúteo. }\end{array}$ & Simon et al., 1997 \\
\hline $\mathrm{KOCx} 40$ & $\begin{array}{l}\text { Diminuição da velocidade de condução atrial e ventricular; } \\
\text { Pré-disposição à arritmia. }\end{array}$ & $\begin{array}{l}\text { Kirchoff et al., } \\
\text { 1998; Hagendorff } \\
\text { et al., 1999 }\end{array}$ \\
\hline $\mathrm{KOC} \times 43$ & $\begin{array}{l}\text { Morte pré-natal dos embriões resultantes das más formações cardíacas: } \\
\text { obstrução dos vasos sangüíneos ventriculares direito e da artéria pulmonar; } \\
\text { Alterações estruturais do cristalino: catarata; } \\
\text { Diminuição do tamanho das gônadas no macho e na fêmea quando do } \\
\text { nascimento: bloqueio da foliculogênese ovariana no estágio de folículo } \\
\text { primário; } \\
\text { Retardo na ossificação, anomalias craniofaciais resultantes de migração das } \\
\text { células da Creta neural; }\end{array}$ & $\begin{array}{l}\text { Reaume et al., } \\
\text { 1995; } \\
\text { Gao et al., 1998; } \\
\text { Juneja et al., 1999; }\end{array}$ \\
\hline $\begin{array}{l}\text { KO para o } \\
\text { coração e o } \\
\text { endotélio }\end{array}$ & $\begin{array}{l}\text { Defeitos de hematopoese; } \\
\text { Estrutura anormal do coração; } \\
\text { Sem alterações na pressão sangüínea, porém, os animais heterozigotos para } \\
\text { esta conexina apresentam } 30 \% \text { a menos de capacidade na condução do } \\
\text { sangue. }\end{array}$ & $\begin{array}{l}\text { Lo et al., } 1997 \text {; } \\
\text { Montecino- } \\
\text { Rodrigguez et al., } \\
2000 \text {. } \\
\text { Theis et al., } 2001\end{array}$ \\
\hline KOCx45 & Morte embrionária com presença de anomalias cardíacas. & $\begin{array}{l}\text { Kumar et al., 2000; } \\
\text { Kruger et al., } 2000\end{array}$ \\
\hline KOCx46 & $\begin{array}{l}\text { Catarata nuclear associada de proteólise do cristalino após o } \\
\text { nascimento; } \\
\text { Importância de fundo genético dos camundongos vis-à-vis no estado } \\
\text { do desenvolvimento da catarata. }\end{array}$ & $\begin{array}{l}\text { Gong et al., 1998; } \\
1999\end{array}$ \\
\hline KOCx50 & $\begin{array}{l}\text { Viáveis mais desenvolvem catarata após uma semana ao } \\
\text { nascimento; } \\
\text { Redução do tamanho do cristalino e do olho. }\end{array}$ & White et al., 1997 \\
\hline $\begin{array}{l}\mathrm{KOC} \times 32- \\
\mathrm{Cx} 43\end{array}$ & Morte pré-natal seguida de má formação cardíaca. & $\begin{array}{l}\text { Houghton et al., } \\
1999\end{array}$ \\
\hline Cx43KI32 & $\begin{array}{l}\text { Esterilidade masculina devido a deficiências de células germinativas; } \\
\text { Arritmia ventricular espontânea; } \\
\text { Viáveis, morfologia cardíaca normal; } \\
\text { Viáveis, esterilidade masculina devido a deficiências de células } \\
\text { germinativas; } \\
\text { Leves defeitos cardíacos. }\end{array}$ & Plum et al., 2001 \\
\hline
\end{tabular}


Mutações no gene da Cx26 estão associadas a duas formas da surdez não sindrômica. Uma forma recessiva (DFNB1) e uma forma dominante (DFNA3). Estas mutações não se situam em uma região particular do gene, mas estão distribuídas ao longo de toda a seqüência codificadora. De modo interessante, nota-se que determinadas mutações do gene da Cx26 podem estar associadas a vários processos patológicos. Por exemplo, a mutação R75W do gene da Cx26 produz uma surdez associada a uma queratodermia palmoplantar. Do mesmo modo a mutação $\mathrm{D} 66 \mathrm{H}$ conduz a uma surdez associada à síndrome de Volwinkel (queratodermia alveolar associada a uma constrição dos dedos e das orelhas conduzindo a uma auto-amputação).

O mesmo se observa para o gene da Cx30 cuja mutação pode levar a uma surdez e onde mutações de diferente natureza podem provocar a síndrome de Clouston (hiperqueratose palmoplantar associada a uma hipotricose generalizada e uma distrofia das unhas). No caso do gene da Cx31, mutações podem estar associadas a 3 doenças diferentes: 2 formas de surdez e eritoqueratodermia variabilis $(E K V)$ que se manifesta por meio de manchas vermelhas transitórias sobre a pele e uma hiperqueratose palmoplantar. A tabela 6 mostra que um mesmo processo patológico pode estar associado a mutações sobre genes de diferentes Cx.

2.8.2.2 Estudos dos fenótipos de camundongos knockouts para um gene da conexina

Devido a grande diversidade de genes de Cxs expressos, uma das estratégias empregadas para se conhecer a função de cada uma delas sobre o desenvolvimento e funcionamento dos órgãos foi de invalidar o gene no 
camundongo. Até agora, a invalidação ou "knock-out" (KO) foi efetuado para nove genes de Cx diferentes, os fenótipos que resultaram estão descritos na tabela 7.

Em determinadas ocasiões, os fenótipos obtidos foram os esperados, mas em outras situações, foram decepcionantes. Por outro lado, novas informações sobre a função das JG in vivo foram conseguidas. Foi desta maneira que a invalidação do gene da Cx43 mostrou sua função na morfogênese cardíaca, enquanto que a do gene da Cx32 não reproduziu de modo esperado o defeito de mielinização. Esta técnica também permitiu observar a função da Cx26 na transferência transplacentária de nutrientes ou ainda aquela da Cx37 durante a ovulação permitindo a comunicação heteróloga entre as células da granulosa e o oócito. Estes estudos deram origem há uma discordância entre os sintomas observados nas doenças genéticas relacionadas a uma dada conexina, e o fenótipo obtido no camundongo após a invalidação do mesmo gene. Foi desta forma também que se descobriu que a invalidação do gene da Cx26 no camundongo é letal entre a décima e há décima primeira semana pós-coito, enquanto que mutações inativadoras no homem levam a surdez e a problemas dermatológicos. Estas diferenças se explicam através das diferenças anatômicas existentes no homem e no animal. De maneira interessante, uma vez que o fenótipo do camundongo cujo gene da Cx46 ou da Cx50 invalidados reproduziu os sintomas da doença observada no homem (i.e. aparecimento da catarata), certos autores destacaram a importância do background genético dos camundongos para o fenótipo observado (GONG et al., 1999).

Um estudo recente utilizando a tecnologia de "knock-in" (KI) consistindo em fazer expressar uma conexina em lugar de outra (substituindo sua seqüência codificadora por outra conexina e conservando o mesmo promotor) confirmou que determinadas Cxs têm funções comuns. Isto poderia explicar os fenômenos de 
redundância funcional observado nos KO. A substituição do gene da Cx43 pelo da Cx32 ou da Cx40 permitiu evitar a morte perinatal de camundongos quando da invalidação do gene da Cx43, entretanto a expressão do gene da Cx32 substituindo o da Cx43 levou a um defeito da ejeção do leite na glândula mamária; a substituição da Cx43 pela Cx40 ou Cx32 levou a esterilidade masculina. Estas observações mostram que uma Cx não pode substituir uma outra Cx em todos os órgãos e que, em certos casos, levam a perturbação como as relacionadas aqui.

Os estudos comparados dos fenótipos de camundongos $\mathrm{KO}$ e $\mathrm{KI}$ e também de camundongos trasngênicos superexpressando uma $\mathrm{Cx}$ de maneira induzida e/ou tecido específico em paralelo ao estabelecimento do perfil de expressão das Cx deveriam ajudar a compreender a função própria de cada Cx.

\subsubsection{3 $\mathrm{O}$ camundongo $\mathrm{Cx} 43^{-/-}$}

Camundongos deficientes em conexina 43 foram criados por Reaume et al., 1995, na década denominada pelos pesquisadores de a década do camundongo. A Cx43 é observada já nos primeiros estágios da formação do embrião, i.e., quando apenas oito células estão presentes, estágio de blástula.

O intuito da equipe de Reaume foi o de se observar à influência da deleção total do gene desta conexina sobre o desenvolvimento do embrião. Para a surpresa destes pesquisadores quando do nascimento da prole; este havia se desenvolvido normalmente sobrevivendo ainda por alguns minutos. A necrópsia destes animais provou que a causa mortis era devido à má formação cardíaca. Da conclusão publicada na época, especulava-se a possibilidade de que outras conexinas presentes terem compensado a deficiência da Cx43 e que, enquanto no útero, a mãe, supriria de nutrientes e oxigênio o embrião. Mais recentemente, Lecanda et al. 
(2000), mostraram que além de má formação cardíaca, estes animais também apresentavam má formação craniana, da mandíbula, do antebraço, da clavícula e das costelas (Figura 13).

Devido ao fato da Cx43 ser a principal proteína das junções do tipo gap em vários tecidos ou órgãos, os camundongos deficientes nessa conexina vêm sendo usados para a compreensão de seu papel nesses órgãos ou tecidos.

Um resumo dos principais estudos já realizados com esses camundongos até o momento é apresentado na tabela 8. A maior parte dos estudos centra-se no miocárdio e função cardíaca, seguida por estudos envolvendo células germinativas/ gônadas, hematopoiese, sistema nervoso central e etc. 

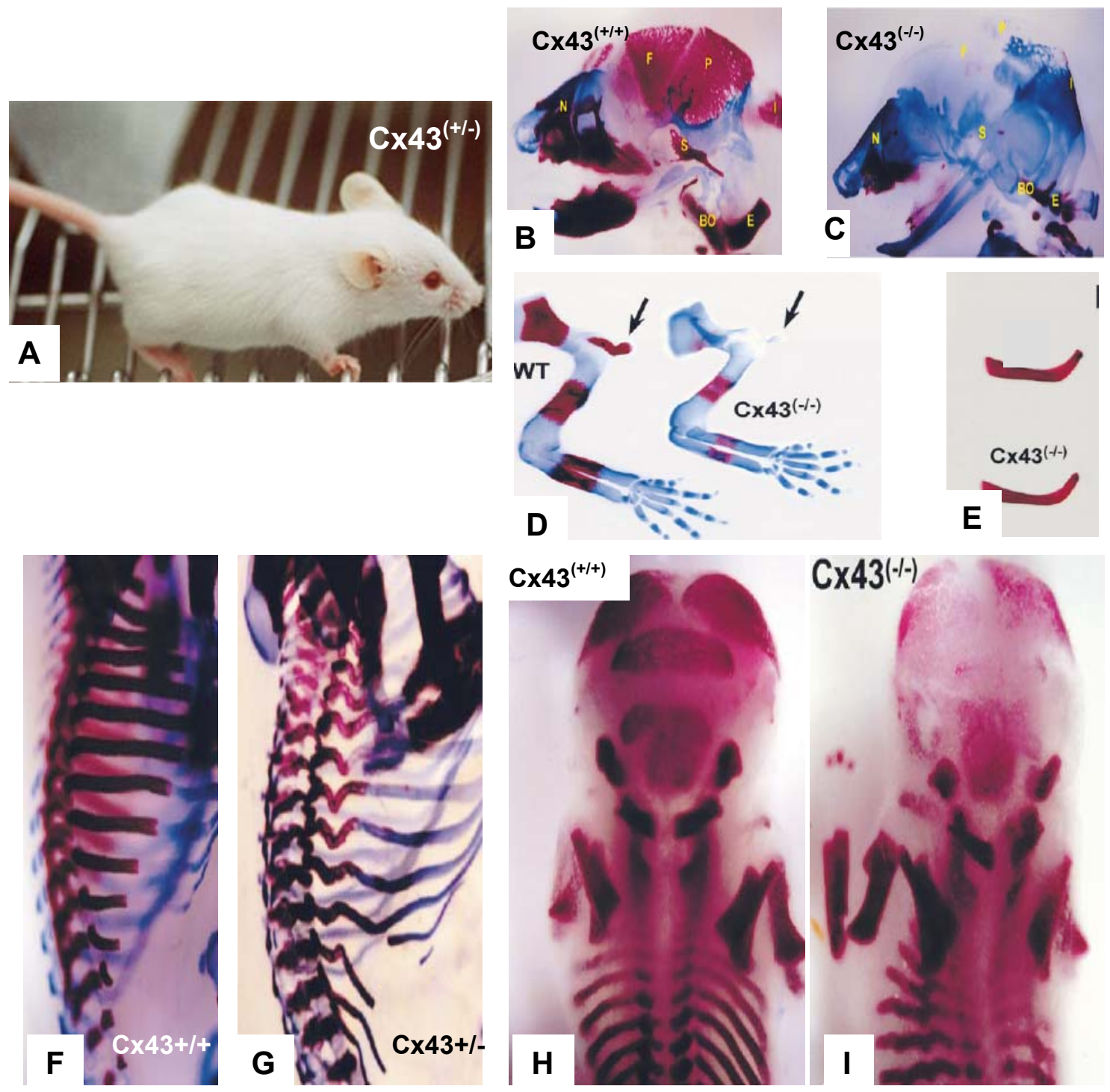

Figura 13 - A. Camundongo $\mathrm{C} \times 43^{+/-}$utilizado em nossos experimentos. B.C. Comparação entre as mandíbulas de um camundongo $\mathrm{C} \times 43^{+/+}$e $\mathrm{C} \times 43^{-/}$. D. Membros anteriores (braços). E. Clavículas F.G. Ilustração apresentando as costelas de ambos os animais. H.I. Calota craniana (Adaptado de LECANDA et al., 2000) 
Tabela 8 - Principais estudos utilizando a linhagem de camundongos deficientes em conexina 43

\begin{tabular}{|c|c|}
\hline Órgão/Sistema & Referências \\
\hline $\begin{array}{l}\text { Coração/ Função } \\
\text { Cardíaca }\end{array}$ & $\begin{array}{l}\text { Guerrero et al., 1997; Johnson et al., } \\
\text { 1999; Johnson et al., 2002; Liu; Gutstein, } \\
\text { 2002; Lo, 1996; Morley et al., 2000; } \\
\text { Reaume et al., 1995; Stone, 1995; Vaidya } \\
\text { et al., } 2001\end{array}$ \\
\hline Gônadas & $\begin{array}{l}\text { Ackert et al, 2001; Batias et al., 1999; } \\
\text { Gittens et al., 2003; Juneja et al., 1999; } \\
\text { Kimura et al., 1999; Roscoe et al., } 2001\end{array}$ \\
\hline Medula óssea / & Cancelas et al., 2000 \\
\hline Hematopoiese & Montecino-Rodrigues; Dorshkind, 2001. \\
\hline SNC/ SNP & $\begin{array}{l}\text { Dermietzel et al., 2000; Fushiki et al., } \\
\text { 2003; Naus et al., 1999; Zhao et al., } 1999\end{array}$ \\
\hline Cristalino & Gao et al., 1998; White et al., 2001 \\
\hline Macrófagos & Alves et al., 1996 \\
\hline Pele & Yamakage et al., 2000 \\
\hline Células Endoteliais & Liao et al., 2001 \\
\hline Rim & Silverstein et al., 2001 \\
\hline Ossos & Lecanda et al., 2000 \\
\hline
\end{tabular}

Fonte Guerra, J.L. Hepatocarcinogênese em camundongos portadores de deleção em um dos alelos da conexina 43 (Cx43+/-). 2003. 95 f. Tese (Livre-Docência) - Faculdade de Medicina Veterinária e Zootecnia da Universidade de São Paulo, São Paulo, 2003. 


\subsection{CONTROLE DA PROLIFERAÇÃO CELULAR E DA DIFERENCIAÇÃO CELULAR PELAS JUNÇÕES DO TIPO GAP}

\subsubsection{GJIC e carcinogênese}

$\mathrm{Na}$ ausência de processos patológicos, a proliferação das células é um processo estritamente controlado em todos os órgãos. A capacidade das células de proliferar é freqüentemente relacionada à sua capacidade de se diferenciar ou de expressar marcadores de diferenciação. No caso da pele, por exemplo, a renovação das células se faz por multiplicação de células tronco que se diferenciam, perdendo progressivamente, sua capacidade de proliferação. Nas células cancerosas, este equilíbrio entre proliferação e diferenciação está rompido.

A carcinogênese é um processo multi-estágio: na etapa de iniciação, alterações genéticas se acumulam progressivamente em uma célula até que ela adquira um conjunto completo de genes modificados (cinco a seis genes alterados) conduzindo à expressão do fenótipo maligno, em seguida, a etapa de progressão resulta na expansão clonal de células iniciadas. Quando estes grupos de células adquirem alterações genéticas suficientes, elas se tornam neoplásicas e adquirem um comportamento de independência e de invasividade originando metástases. Os genes modificados freqüentemente encontrados nos diferentes cânceres humanos estão em geral implicados no controle da proliferação celular, por exemplo, o p53 e o ras. Além destes genes convencionais implicados no controle do ciclo celular de células individuais, existe um segundo grupo de genes de controle da proliferação celular que intervém no quadro de harmonização do comportamento proliferativo de uma célula com seus homólogos ao redor. Estes são genes que codificam proteínas 
implicadas nos processos de reconhecimento e de comunicação intercelular com as moléculas de adesão celular ou as Cx.

As primeiras observações sobre a implicação da CIJG na carcinogênese foram obtidas por Loewenstein e Kanno, 1966, que observaram que as células cancerosas apresentavam decréscimo da capacidade de comunicação intercelular em relação às células normais. Estas observações foram mais tarde confirmadas em tecidos cancerosos ou linhagens celulares estabelecidas a partir de célula tumorais ou por transformação de células tumorais. Da mesma forma foi mostrado que a comunicação juncional entre as células tumorais (comunicação homóloga) ou entre células tumorais e células normais (comunicação heteróloga) está geralmente diminuída ou interrompida. Isto foi observado tanto in vivo quanto in vitro (KRUTOVSKIKH et al., 1991; YAMASAKI, 1990). Yamasaki et al. (1990) mostraram que a restituição da capacidade de comunicação reverte o fenótipo canceroso de certas linhagens celulares. Sabe-se atualmente que a diminuição da CIJG em células tumorais pode ser devida a uma perda de expressão das conexinas ou a sua localização aberrante (FITZGERALD et al., 1989; KRUTOVSKIKH et al., 1994; LEE et al., 1991). A presença das JG protege as células de um desenvolvimento anárquico. Numerosos outros argumentos mantêm esta hipótese tais como:

A adição de agentes promotores de tumor como o TPA;

A expressão de oncogenes como o src, o antígene $T$ de SV40, ras; e inversamente o fato de que:

A adição de agentes anit-tumorais ou quimiopreventivo (retinóides, glicocorticóides, $A M P c$, flavonóides, compostos do chá verde) estimulam a GJIC (YAMASAKI, 1990; YAMASAKI et al., 1996). 
O restabelecimento da comunicação via JG em linhagens celulares com comunicação deficiente, consecutivamente a transfecção de cDNA de Cx, é freqüentemente correlacionada inversamente com o nível de proliferação destas células; a observação inversa é feita no caso da inibição da CIJG pelo bloqueio da expressão de Cx endógena.

De maneira interessante, na maioria dos casos estudados até hoje, não foram encontradas mutações nos genes das conexinas nos tecidos cancerosos, com exceção de uma mutação do gene da Cx32 em neoplasma hepático de rato quimicamente induzido, levando a uma localização aberrante da Cx (YAMASAKI et al., 1995). Além de mutações silenciosas no gene da Cx43 em linhagens de células de carcinoma de rato Lewis e uma mutação no gene da Cx43 em câncer de cólon (DUBINA et al., 2002) foram observadas. Nenhuma mutação do gene da Cx37 foi observada entre os angiosarcomas hepáticos humanos expostos ao cloreto de vinil, adenocarcinomas pulmonares ou carcinomas esporádicos de mama (KRUTOVSKIKH et al., 1996; SAITO et al., 1997).

Devido à ausência de mutações nos genes das conexinas nos cânceres, as conexinas foram classificadas como genes supressores de tumores do tipo II após estudos de hibridização subtrativa em células de carcinoma mamário (LEE et al., 1991). Diferentemente dos genes supressores de tumores, como é o caso do p53 que é freqüentemente encontrado mutado, nesta classificação encontram-se as proteínas cuja presença é importante para a manutenção da homeostasia, porém nenhuma mutação importante foi descrita.

$\mathrm{Na}$ maioria dos tumores, a localização aberrante das conexinas tem sido descrita. Esta perda na GJIC em células tumorais foi primeiro descrito por Loewenstein e Kanno (1966). Muitos outros estudos posteriores confirmaram que as 
células cancerosas perdem ou apresentam diminuída capacidade de GJIC (LEE et al., 1992; NEI et al., 1999; SAITO et al., 1998). Recentemente, Nishimura et al. (2003) mostraram que células tumorais que apresentavam conexinas anormalmente localizadas estavam diretamente ligadas a expressão da caderina E. A caderina E é uma molécula de adesão dependente de $\mathrm{Ca}^{+2}$ que, associada com $\alpha, \beta$, e $\gamma$ catenina, constituem a principal componente das junções aderentes nos vertebrados e esta combinação é essencial para o estabelecimento do contato físico célula com célula (NEI et al., 1999). Nishimura et al. (2003), mostraram que a expressão da caderina $E$ é down-regulated na célula através de ilhas de metilação $5^{\prime} \mathrm{CpG}$, que indiretamente provoca a supressão da capacidade de comunicação entre as células via conexinas em células de carcinoma endometrial.

A anomalia da comunicação intercelular via JG observada nos cânceres, também permitiu elaborar novas terapias com o objetivo de bloquear a formação de tumores. Uma técnica direta consistiria em expressar os genes das Cx por transgênese nas células tumorais com a finalidade de restabelecer a comunicação com as células normais e assim, tentar reverter o fenótipo maligno. Outra opção seria a de explorar a faculdade de determinadas células cancerosas de se comunicarem entre si, mas não com as células normais. Dessa forma, pode-se injetar diretamente no tumor uma substância tóxica que se limitaria a eliminar esta população em particular.

Uma variante desta técnica, que não é explorada diretamente, é a técnica conhecida como "efeito bystander" (ou efeito de proximidade). Esta técnica consiste em expressar especificamente nas células cancerosas o gene que codifica para a timidina cinase (tk-HSV). Esta enzima, de origem viral, permite a fosforilação do ganciclovir que é uma substância análoga dos nucleotídeos. A incorporação do 
ganciclovir fosforilado no material genético para a replicação do DNA e conduz à morte celular. Se as células tumorais são forçadas a se comunicar entre si (graças à expressão de uma Cx alvo, por exemplo), o ganciclovir fosforilado se difundirá de uma célula a outra e levará a morte um grande número de células tumorais, compreendendo mesmo as células que não expressam a tk (MESNIL et al., 1996; YAMASAKI; KATOH, 1988). Assim, estudos in vitro têm mostrado que em uma população de células HeLa, entre as quais apenas 10\% das células incorporaram o gene da timidina quinase, a expressão concomitante da Cx43 (ou da Cx26), permitiu a eliminação da população toda após a adição do ganciclovir (MESNIL et al., 1997). Há relatos da utilização desta técnica in vivo (DUFLOT-DANCER et al., 1998), porém, sua utilização no homem ainda está distante de ser utilizada devido à escassez de vetores que possam levar os trans-genes necessários a células específicas.

\subsubsection{Função das Cx no controle da proliferação e da diferenciação celular}

A tabela 9 recapitula para cada Cx o impacto sobre a proliferação de células in vitro ou sobre sua tomorigenicidade in vivo (em camundongo nude), tão quão sobre a expressão de caracteres de diferenciação. Praticamente em todos os casos algumas características são evidentes: 1) a expressão das Cx é acompanhada do restabelecimento da comunicação celular; 2) a proliferação celular observada é diminuída; 3) os efeitos observados para uma dada Cx não são reproduzidos em todos os tipos celulares, por exemplo, a expressão da Cx32 induz a diminuição da proliferação celular in vitro em uma linhagem de hepatócitos de ratos (WB-F344aB1) (RAE et al., 1998), mas o mesmo não acontece em células de HeLa (OMORI; 
YAMASAKI, 1999); 4) Cx diferentes não reproduzem o mesmo efeito sobre a proliferação de um mesmo tipo celular. Isto é particularmente bem ilustrado no trabalho de Mesnil et al (1995) que mostra que em células de HeLa, a expressão da Cx26 leva a uma diminuição de sua proliferação mas ao contrário, nem a expressão da Cx40 ou da Cx43 reproduzem este efeito. Concluindo de modo interessante, a Cx26 é a principal conexina expressa no colo do útero humano, que é o tecido que deriva as células de HeLa. Estes resultados sugerem que os efeitos das Cx sobre o controle da proliferação celular poderiam ser dependentes do tipo celular no qual elas são expressas. 5) O impacto da expressão de uma Cx não é reproduzido da mesma forma in vitro e in vitro em todos os camundongos nude. É o caso, por exemplo, da Cx32 que induz uma diminuição do crescimento in vivo, mas não in vitro quando ela é expressa nas células tumorais de hepatócitos humanos (EGHBALI et al., 1990; 1991) ou para a Cx43 nas células tumorais derivada da bexiga de rato (KRUTOVSKIKH et al., 1998). Isto pode estar associado à quantidade de Cx expressa uma vez que tal fenótipo é freqüentemente observado após a expressão induzida e transitória de Cx (BECHBERGER et al., 1996; KIANG et al., 2000). Entretanto, não é descartado que a função supressora de tumor das Cx seja potencializada in situ em relação à in vitro ou que a expressão da Cx pode atuar em diferentes níveis e mesmo por meio de diferentes mecanismos contribuindo para reverter o fenótipo maligno das linhagens celulares tumorais. 6) Paralelamente a diminuição da velocidade de proliferação celular, a expressão de Cx é acompanhada em determinadas linhagens celulares da reexpressão de caracteres de diferenciação. Como por exemplo, a Cx43 nas células de rabdomiosarcomo onde se observou um aumento do nível de expressão de miosina (PROULX et al., 1997a), ou em células transformadas do pâncreas que secretam mais insulina (VOZZI et al., 
1995); células tumorais de próstata humana LNCap se diferenciam após a expressão da Cx32 e da Cx43 (MEHTA et al., 1999). Da mesma forma para o controle da proliferação celular, nem todas as conexinas exercem o mesmo efeito sobre o nível de expressão de caracteres de diferenciação. Células tumorais derivadas de trofoblastos humanos secretam mais $\beta$-hCG após a expressão da Cx26 que após a expressão da Cx40 (HELLMANN et al., 1999).; as células tumorais derivadas da glândula mamária readquirem uma maior capacidade de formar estruturas tridimensionais consecutivamente após a expressão da Cx26 que após a Cx43 (GRAEBER et al., 1988). Segundo Rosenberg et al. (1996), existe uma correlação entre o nível de expressão de RNAm das Cx32, Cx26 e Cx43 no fígado e o grau de diferenciação celular dos hepatócitos (ROSENBERG et al., 1996). 


\begin{tabular}{|c|c|c|c|c|c|c|}
\hline \multirow{2}{*}{ Linhagem Celular } & \multirow{2}{*}{ Cx } & \multirow{2}{*}{ CIJG } & \multicolumn{2}{|c|}{ Efeito sobre a proliferação } & \multirow{2}{*}{ Outros efeitos } & \multirow{2}{*}{ Referência } \\
\hline & & & In vitro & In vivo* & & \\
\hline \multirow{3}{*}{$\begin{array}{l}\text { SKHep1 - fígado } \\
\text { humano (Câncer) }\end{array}$} & $\mathrm{Cx} 32 \mathrm{r}$ & + & $\Leftrightarrow$ & $\Downarrow$ & $\begin{array}{l}\text { Efeito sobre o crescimento dependendo do nível de } \\
\text { expressão da conexina e do nível de comunicação induzida. }\end{array}$ & $\begin{array}{l}\text { Eghbali et al., } 1990 . \\
1991\end{array}$ \\
\hline & Cx43h & + & n.d. & n.d. & Caracterização do cDNA Gja1 clonado: canis funcionais. & Fishamn et al., 1990 \\
\hline & $\begin{array}{l}\text { Cx32r } \\
\text { ind }\end{array}$ & + & $\Leftrightarrow$ & n.d. & Meia-vida do RNAm da Cx32 estimado em 4 horas. & Fishamn et al., 1990 \\
\hline \multirow{5}{*}{$\begin{array}{l}\text { Glioma C6 - } \\
\text { astrócitos rato } \\
\text { (cérebro) CIGJ } \\
\text { baixo; Cx43 } \\
\text { endógena }\end{array}$} & $\mathrm{Cx} 43 \mathrm{r}$ & + & $\Downarrow$ & $\Downarrow$ & $\begin{array}{l}\text { Correlação do nível da CIJG / inibição da proliferação; } \\
\text { Sem aumento do nível de apoptose; } \\
\text { Variaçães no nível de secreção de fatores inibidores da } \\
\text { proliferação in vitro de células selvagens: } \Uparrow \text { IGFBP-4 e } \Downarrow \\
\text { IGFBP-3; } \\
\text { Correlação do nível de expressão da Cx43 com a via de } \\
\text { sinalização Ca }{ }^{+2} \text { dependente; } \\
\text { Analise comparativa por RT-PCR dos transfectantes com as } \\
\text { células selvagens: } \Uparrow \text { RNAm cyr61, osteopopntina, gene KC. }\end{array}$ & $\begin{array}{l}\text { Bradshaw et al., } 1993 \\
\text { Charles et al., } 1992 \\
\text { Naus et al., } 1992 \\
\text { Naus et al., } 2000 \\
\text { Zhu et al., } 1992 \\
\end{array}$ \\
\hline & $\mathrm{Cx} 43 \mathrm{r}$ & + & $\Leftrightarrow$ & n.d. & $\begin{array}{l}\text { Diminuição da densidade de saturação e aumento do nível de } \\
\text { MFG-E8 secretado. }\end{array}$ & Goldberg et al., 2000 \\
\hline & $\begin{array}{l}\text { Cx43r } \\
\text { ind }\end{array}$ & + & $\Leftrightarrow$ & $\Downarrow$ & $\begin{array}{l}\text { Correlação do nível de expressão da Cx43 com inibição da } \\
\text { tumorigenicidade. }\end{array}$ & Bechberger et al., 1996 \\
\hline & $\mathrm{Cx} 32 \mathrm{r}$ & + & $\Downarrow$ & $\Downarrow$ & $\begin{array}{l}\text { Correlação entre o nível da ClJG e } \quad \text { o nível da } \\
\text { tumorigenicidade; } \\
\text { Sem correlação entre o nível de expressão da Cx32 e a } \\
\text { inibição da proliferação in vitro. }\end{array}$ & Bond et al., 1994 \\
\hline & Cx30r & + & $\Downarrow$ & n.d. & & Princen et al., 2001 \\
\hline $\begin{array}{r}\text { U251 - humano } \\
\text { (Cáncer); } \\
\text { glioblastoma } \\
\text { (cerebro) } \\
\text { T98G - não tumoral } \\
\text { neuroblastoma } \\
\text { (cerebro); } \\
\text { CIJG: baixo; sem } \\
\text { Cx43 endógena. }\end{array}$ & Cx43h & - & $\Downarrow$ & $\Downarrow$ & $\begin{array}{l}\text { Diminuição da densidade de saturação; } \\
\text { Aumento da duração da fase G1 do ciclo celular; } \\
\text { Alterações morfológicas das células: maiores e epitelióides; } \\
\text { Ausência do restabelecimento da ClJG: endereçamento } \\
\text { aberrante da Cx43 (citoplasmática e nuclear); } \\
\text { Efeito supressor de tumor independente da CIJG }\end{array}$ & Huang et al., 1998 \\
\hline
\end{tabular}


(Continuação)

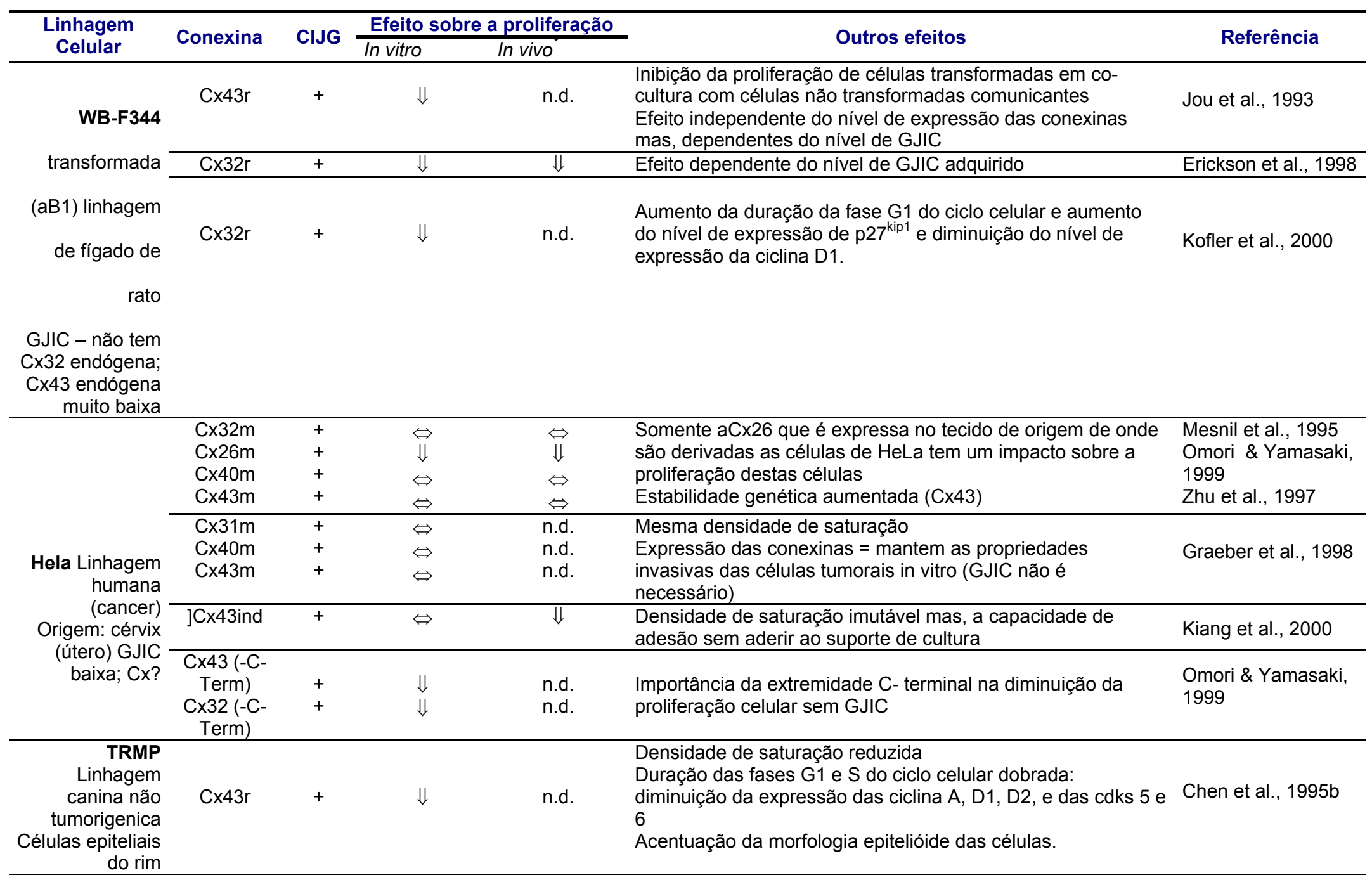


(Continuação)

\begin{tabular}{|c|c|c|c|c|c|c|}
\hline \multirow[t]{2}{*}{$\begin{array}{l}\text { Linhagem } \\
\text { Celular }\end{array}$} & \multirow[t]{2}{*}{ Conexina } & \multirow[t]{2}{*}{ CIJG } & \multicolumn{2}{|c|}{$\begin{array}{c}\text { Efeito sobre a } \\
\text { proliferação }\end{array}$} & \multirow[t]{2}{*}{ Outros efeitos } & \multirow[t]{2}{*}{ Referência } \\
\hline & & & In vitro & In vivo & & \\
\hline $\begin{array}{r}\text { E9 } \\
\text { Linhagem de } \\
\text { camundongos } \\
\text { (cancer); }\end{array}$ & $\begin{array}{l}\text { Cx43m } \\
\text { Cx32m }\end{array}$ & $\begin{array}{l}+ \\
+\end{array}$ & $\stackrel{\Downarrow}{\Leftrightarrow}$ & $\begin{array}{l}\Downarrow \\
\Downarrow\end{array}$ & $\begin{array}{l}\text { Diminuição da densidade de saturação } \\
\text { Diminuição da densidade de saturação } \\
\text { A expressão da Gja1 esta correlacionada há uma } \\
\text { reversão do fenótipo neoplásico de maneira mais } \\
\text { acentuada que após a transfecção da Cx32 }\end{array}$ & $\begin{array}{l}\text { Ruch; Cesen- } \\
\text { Cummings, } 1998\end{array}$ \\
\hline $\begin{array}{r}\text { Células } \\
\text { epiteliais do } \\
\text { pulmão; GJIC } \\
\text { baixa, Cx43 } \\
\text { endógena baixa } \\
\end{array}$ & $\mathrm{Cx} 43 \mathrm{~m}$ & + & $\Downarrow$ & n.d. & $\begin{array}{l}\text { Aumento da duração da fase G1 do ciclo celular e } \\
\text { aumento do nível de expressão de p2 } 27^{\text {kip1 }} \text { e diminuição } \\
\text { do nível de expressão de ciclina D1 }\end{array}$ & Koffler et al., 2000 \\
\hline $\begin{array}{r}\text { MCA-10 } \\
\text { Linhagem de } \\
\text { camundongos } \\
\text { (transformada } \\
10^{1 / 2} \text { ) }\end{array}$ & $\mathrm{C} \times 43 \mathrm{r}$ & + & $\Downarrow$ & $\Downarrow$ & $\begin{array}{l}\text { Densidade de saturação reduzida } \\
\text { Efeito proporcional a superexpressão da Cx43 }\end{array}$ & $\begin{array}{l}\text { Mehta et al., } 1991 \\
\text { Rose et al., } 1993\end{array}$ \\
\hline $\begin{array}{r}\text { RDL6 } \\
\text { Linhagem } \\
\text { humana } \\
\text { (cancer); } \\
\text { Rabidosarcoma; } \\
\text { GJIC Baixa, } \\
\text { Cx43 endógena } \\
\text { baixa }\end{array}$ & $\mathrm{C} \times 43 \mathrm{r}$ & + & $\Downarrow$ & n.d. & $\begin{array}{l}\text { Aumento da fusão membranar das células } \\
\text { Aumento da expressão do gene da miosina }\end{array}$ & $\begin{array}{l}\text { Lin et al., } 1995 \\
\text { Proulx et al., } \\
1997 a\end{array}$ \\
\hline $\begin{array}{r}\text { Jeg3 } \\
\text { Linhagem } \\
\text { humana } \\
\text { (câncer); } \\
\text { Origem: } \\
\text { trofoblasto GJIC } \\
\text { baixa, Cx40 } \\
\text { endógena baixa } \\
\end{array}$ & $\begin{array}{l}\text { Cx26r } \\
\text { Cx40h } \\
\text { Cx43h }\end{array}$ & $\begin{array}{l}+ \\
+ \\
+\end{array}$ & $\begin{array}{l}\downarrow^{(1)} \\
\downarrow^{(2)} \\
\Downarrow\end{array}$ & $\begin{array}{l}\Downarrow \\
\Leftrightarrow \\
\Leftrightarrow\end{array}$ & $\begin{array}{l}\text { Diferenciação de células: aumentada, aumento da } \\
\text { secreção de betahCG dependente do nível de GJIC e } \\
\text { da Cx expressa (Cx26>Gja1) } \\
\text { (1) efeito sobre a proliferação dependente do nível } \\
\text { de GJIC } \\
\text { (2) efeito sobre a proliferação aumentada com a } \\
\text { GJIC }\end{array}$ & $\begin{array}{l}\text { Hellmann et al., } \\
1999\end{array}$ \\
\hline
\end{tabular}




\begin{tabular}{|c|c|c|c|c|c|c|}
\hline \multirow{2}{*}{$\begin{array}{l}\text { Linhagem } \\
\text { Celular }\end{array}$} & \multirow{2}{*}{ Conexina } & \multirow{2}{*}{ CIJG } & \multicolumn{2}{|c|}{ Efeito sobre a proliferação } & \multirow{2}{*}{ Outros efeitos } & \multirow{2}{*}{ Referência } \\
\hline & & & In vitro & In vivo & & \\
\hline MDA-MB-435 & Cx43h & + & $\Downarrow$ & $\Downarrow$ & Aquisição da capacidade de formar estruturas tridimensionais & \\
\hline $\begin{array}{r}\text { Linhagem } \\
\text { humana } \\
\text { (câncer); } \\
\text { Células epiteliais } \\
\text { de mama } \\
\end{array}$ & Cx26h & + & $\Downarrow$ & $\Downarrow$ & em uma matriz do tipo Matrigel & Hirschi et al., 1996 \\
\hline $\begin{array}{r}\text { PG } \\
\text { Linhagem } \\
\text { humana } \\
\text { (câncer); } \\
\text { Células epiteliais } \\
\text { do pulmão } \\
\end{array}$ & $\mathrm{Cx} 43 \mathrm{r}$ & + & $\Downarrow$ & $\Downarrow$ & $\begin{array}{l}\text { Aumento da aderência ao substrato } \\
\text { Efeito observado correlacionado com o nível de expressão da } \\
\text { Cx43 }\end{array}$ & Zhang et al., 1998 \\
\hline $\begin{array}{r}\text { INS1 } \\
\text { Células } \\
\text { transformadas; } \\
\text { Células do } \\
\text { pâncreas } \\
\end{array}$ & $\mathrm{Cx} 43$ & & n.d. & n.d. & $\begin{array}{l}\text { Aumento da secreção de insulina dependente do nível exato } \\
\text { de expressão da Cx43 (próximo daquele observado } \\
\text { naturalmente) }\end{array}$ & Vozzi et al., 1995 \\
\hline $\begin{array}{r}\text { BHK } \\
\text { Linhagem de } \\
\text { hamster; Células } \\
\text { epiteliais do rim } \\
\end{array}$ & Cx32h ind & + & $\Leftrightarrow$ & n.d. & $\begin{array}{l}\text { Presença de JG na membrana plasmática, no RE e ao nível } \\
\text { de envelope nuclear }\end{array}$ & Kumar et al., 1995 \\
\hline $\begin{array}{r}\text { LNCap } \\
\text { Linhagem } \\
\text { humana } \\
\text { (cancer) } \\
\text { Células da } \\
\text { próstata } \\
\end{array}$ & $\begin{array}{l}\mathrm{C} \times 32 \\
\mathrm{C} \times 43\end{array}$ & $\begin{array}{l}+ \\
+\end{array}$ & $\begin{array}{lll}\Downarrow \\
\Downarrow \\
\Downarrow\end{array}$ & $\Downarrow$ & $\begin{array}{l}\text { Retardo da tumorigenicidade; Indução da proliferação; perda } \\
\text { do fenótipo normal }\end{array}$ & Mehta et al., 1999 \\
\hline $\begin{array}{r}\text { BC31 } \\
\text { Linhagem de } \\
\text { rato (cancer) } \\
\text { bexiga } \\
\text { GJIC +, Cx43 } \\
\text { endógena baixa } \\
\end{array}$ & $\mathrm{Cx} 43 \mathrm{r}$ & + & $\Leftrightarrow$ & $\Downarrow$ & Efeito dependente do nível de expressão da Cx43 & $\begin{array}{l}\text { Krutovskikh et al., } \\
1998 .\end{array}$ \\
\hline $\begin{array}{r}\text { U2OS } \\
\text { Linhagem de } \\
\text { osteosarcoma } \\
\text { humano }\end{array}$ & $\mathrm{Cx} 43 \mathrm{r}$ & + & $\Downarrow$ & $\bar{\Downarrow} \Downarrow$ & $\begin{array}{l}\text { Aumento da duração da fase } \mathrm{G} 1 \text { do ciclo celular e aumento } \\
\text { do nível de expressão de p } 27^{\text {kip1 }} \text { via regulação pos- } \\
\text { transcrição }\end{array}$ & Zhang et al., 2001. \\
\hline
\end{tabular}




\subsection{SITUAÇÃO DO ASSUNTO DE PESQUISA}

\subsubsection{O epitélio pulmonar}

O epitélio alveolar forma um revestimento contínuo dentro dos sacos alveolares do pulmão. Ele é composto de dois tipos celulares, os pneumócitos do tipo I (APTI) e os do tipo II (APTII). Estes dois tipos de células estão presentes em números similares, mas são morfologicamente e funcionalmente distintas (Figura 14). As APTI são em última instância, células grandes e alongadas que cobrem cerca de $90 \%$ da superfície alveolar. O fino e atenuado citoplasma dos APTI facilitam as trocas gasosas, minimizando a distância de difusão entre o oxigênio alveolar e o $\mathrm{CO}_{2}$ do sangue. Os APTII estão predominantemente localizados nos cantos dos alvéolos e cobrem aproximadamente $10 \%$ da superfície alveolar. Os APTII são células cubóides com núcleo redondo e com a presença de numerosas organelas, incluindo os corpos lamelares, os locais de estoque citoplasmático do surfactante pulmonar (MASON; SHANNON, 1997). 


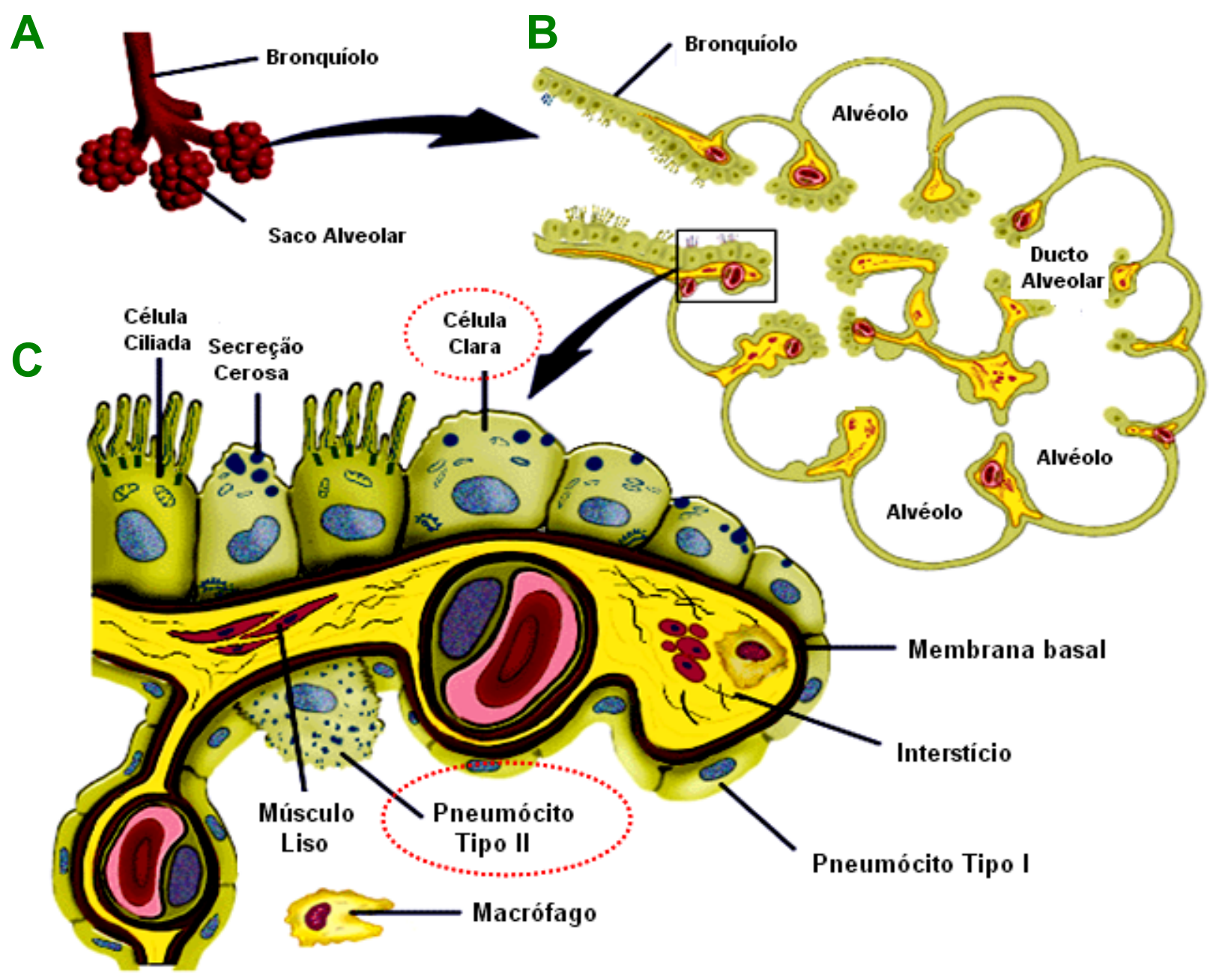

Figura 14 - Principais componentes da estrutura respiratória. A. Sacos alveolares. B. Delimitação entre os bronquíolos e os alvéolos. C. Apresentação das células que compõem os bronquíolos e os alvéolos. É possível observar as principais células responsáveis pelo reparo destas estruturas, as células Clara (no bronquíolo) e os APTII (nos alvéolos) (círculo vermelho) 
O surfactante pulmonar é uma mistura de lipídeos e proteínas, o qual está implicado na regulação da tensão superficial do epitélio alveolar, um processo que é crucial para o funcionamento normal do pulmão. Além da secreção do surfactante, os APTII estão envolvidos também no metabolismo xenobiótico através da atividade da citocromo P-450 (DEVEREUX et al., 1979; JONES et al., 1983), e na regulação do movimento transepitelial de determinados íons (HERBERLEIN et al, 2000). Crescentes evidências têm apontado para funções imuno-modulatórias dos APTII. Estudos têm demonstrado o envolvimento dos APTII na regulação da expressão de moléculas quimiotáticas e de adesão (PAINE et al., 1993; KOYAMA et al., 1998; O'BRIEN et al., 1998a), componentes da matriz pulmonar (MARIANI et al., 1998) através da liberação regulada de citicinas modulatórias, tais como IL-8 a ILGF (GRIFFIN et al., 1993; QUINN et al., 1999).

Outra função dos APTII é a manutenção da integridade do epitélio alveolar. Os APTII são capazes de se proliferar e dar origem a novos APTII, além de substituir uma população original de célula tronco, e se diferenciar em APTI (MANSON; SHANNON, 1997). Dessa forma, os APTII estão envolvidos no reparo do epitélio alveolar, substituindo células danificadas e restaurando a arquitetura normal do tecido e função do pulmão.

\subsection{CARCINOGÊNESE INDUZIDA PELA URETANA}

A história natural das neoplasias de pulmão induzidos pela uretana é bem conhecida (MALKINSON, 1992), constituindo um espectro que vai de focos de hiperplasia de células alveolares até carcinomas. A uretana é um éster etílico do ácido carbâmico, utilizada para produzir hipnose e narcose em mamíferos, peixes e 
anfíbios (ROSSOFF, 1974; GREEN, 1982). Em ratos, é utilizada na dose de $1 \mathrm{~g} / \mathrm{Kg}$ IP ou na água de beber, produzindo adenomas pulmonares (JAFFE 1947; TANNENBAUM et al., 1962). Isto é interessante pelo fato dos ratos serem resistente à carcinogênese pulmonar induzida por outros carcinógenos (JAFFE, 1947). Na década de 40, a uretana foi considerada como um composto que teria possíveis atividades antineoplásicas para se tratar pacientes humanos (HADDOW; SEXTON, 1946; PATERSON et al., 1946). Imediatamente após estas considerações ela foi administrada massivamente em seres humanos com quadros avançados, inoperáveis e intratáveis de carcinomas mamários (HADDOW; SEXTON, 1946; PATERSON et al., 1946). Infelizmente os resultados foram decepcionantes, mas, outros tumores passaram a ser tratados, e o resultado encontrado foi que a uretana provocava leucopenia (HADDOW; SEXTON, 1946; PATERSON et al., 1946). Assim, indivíduos com leucemia e linfoadenopatias foram submetidos ao tratamento e os resultados desta vez foram encorajadores (HADDOW; SEXTON, 1946; PATERSON et al., 1946). Estudos posteriores mostraram que o tratamento com uretana levaria a leucopenia, sedação, náusea, vômitos e necrose hepática (HIRSCHBAECK et al., 1948; HOOVER, 1970). Estudos adicionais mostraram que a uretana também provocava anemia anaplástica irreversível (BOTTNER, 1949), fibrose de lifonodos e pneumonia agranulocítica fatal (LETTERER, 1949).

A presença de uretana é detectada em produtos fermentados como o pão, iogurte, e vinhos na concentração de 1-6 $\mu \mathrm{g} . \mathrm{kg}^{-1}(\mathrm{OUGH}, 1976)$. Outra fonte de uretana seria a folha do tabaco e a própria fumaça do cigarro (HOFFLER et al., 2004). Sob condições normais a ingestão pelos seres humanos adultos é cerca de 20 ng/kg.b.wt, e o risco é questionável. 
Atualmente ela é utilizada apenas como anestésico para animais de laboratório. A uretana tem sido amplamente utilizada em estudos de carcinogênese química em camundongos (BERENBLUM, 1959; MIRVISH, 1968; TRAININ, 1964). Em camundongos sua principal ação é pulmonar produzindo adenocarcinomas, mas também tem sido utilizada para produzir adenomas pulmonares sólidos e papilíferos, embora à relativa porcentagem de cada tipo histológico de tumor varie com a linhagem (BEER; MALKINSON, 1985). De acordo com Shapiro e Kirschbaum (1951), a ordem de susceptibilidade de camundongos a uretana é: A $>$ Swiss $>C B A>D B A$, enquanto Cowen (1950) encontrou $A>C B A>C 57 B L$.

Dois compostos, o vinil carbamato (VC) e seu derivado epoxi podem ser considerados metabólitos eletrofílicos responsáveis pela genotoxicidade e a carcinogenicidade da uretana (Figura 15). O epoxietil carbamato interage com o DNA para formar adutos do tipo 7-(2-oxoetil) guanina (GUPTA; DANI, 1989; MILLER; MILLER, 1983; PARK et al., 1993; SALMON; ZEISE, 1991). Os tumores de pulmão induzidos pela uretana em camundongos apresentam mutações no gene K-ras (TOMISAWA et al., 2003). Foi verificado que o gene do K-ras de camundongo é extremamente sensível a uretana (OGAWA et al., 1996). O codon 61 do gene K-ras é freqüentemente encontrado mutado em manipulações experimentais com este carcinógeno (MITSUMORI et al., 1997; 1998; TOMISAWA et al., 2003).

Devido à natureza proliferativa dos APTII, há um consenso de que os tumores pulmonares induzidos quimicamente pela uretana são oriundos dos APTII (DIXON et al., 1991; MANSON et al., 2000; NOMORI et al., 1994; THAETE et al., 1987; WARD et al., 1985). Isto está baseado na expressão da proteína surfactante A e C e imunistoquimica de algumas citoqueratinas ou a falta da expressão da citoqueratina 10. 


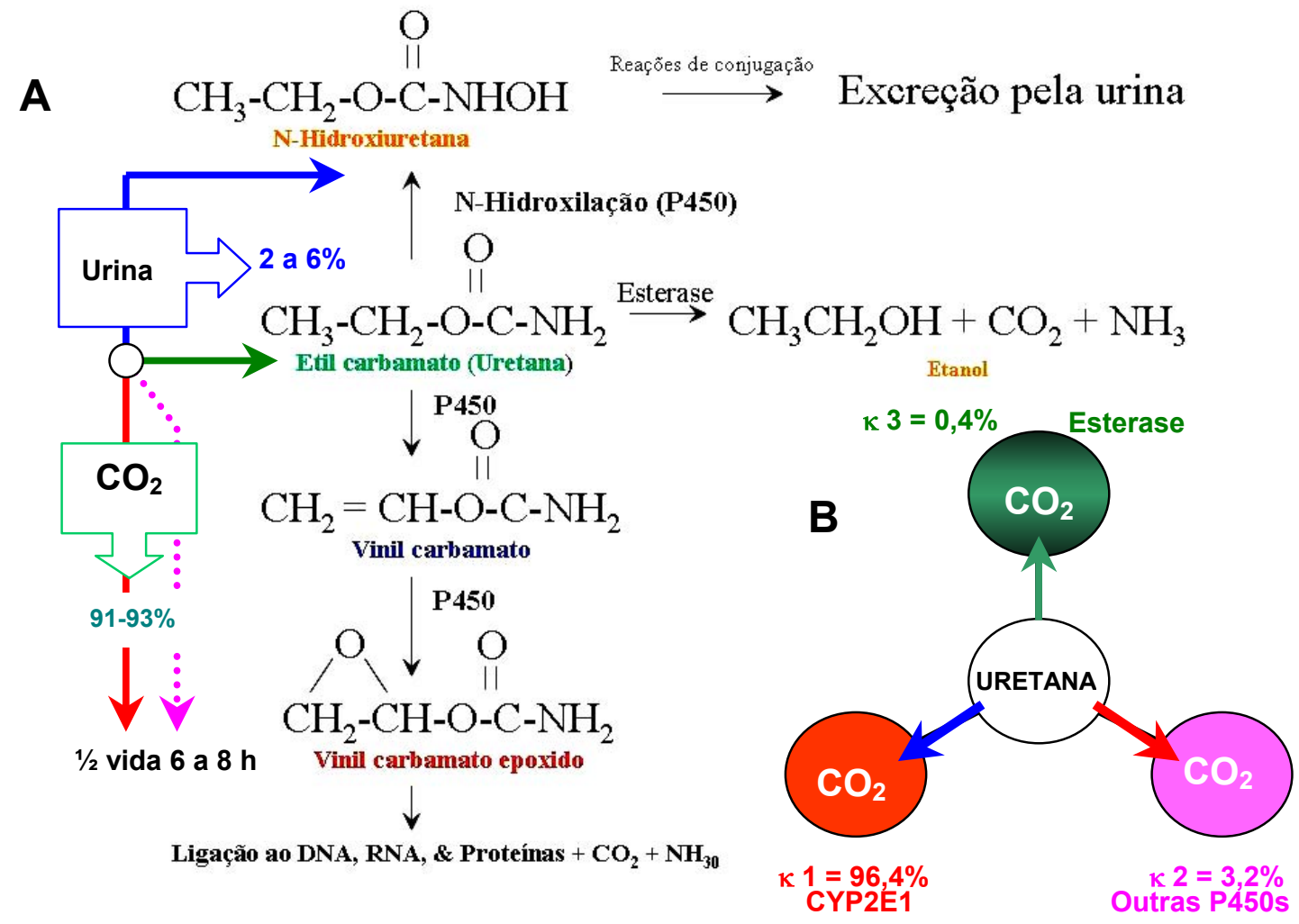

Figura 15 - Esquema proposto para o metabolismo da uretana. Adaptado de Hoffler et al. (2003). A. A uretana é praticamente convertida a $\mathrm{CO}_{2}(91-93 \%)$ pela CYP2E1 $(96,4 \%)$ e uma pequena parte é eliminada pela urina (2-6\%) ou mantida em outros tecidos até sua eliminação. A meia vida de $100 \mathrm{mg} / \mathrm{kg}$ de peso vivo é de 6-8 horas. B. Cinética de conversão da uretana a $\mathrm{CO}_{2}$. A conversão da uretana pela esterase e por outras $P 450$ s a $\mathrm{CO}_{2}$ é pouco representativa 


\subsection{Cx43: A PRINCIPAL CONEXINA EXPRESSA NO TECIDO PULMONAR}

No tecido pulmonar, as células endoteliais e as células musculares lisas expressam a Cx37 (WILLECKE et al., 1999) e a Cx40 (HENNEMANN et al., 1992a; TRAUB et al., 1994). Porém a maior parte das células pulmonares expressa a Cx43, como as células epiteliais de tipos I e II, as células endoteliais dos grandes vasos sanguíneos, e as células musculares lisas da região peribrônquica (KASPER et al., 1996). Há relato da formação de canais heterotípicos de junções do tipo gap compostos por conexinas 40 e 43 (VALIUNAS et al., 2000).

Quando em cultura primária, os APTII expressam mRNAs para as Cx43, Cx46, Cx32 e para a Cx26. Enquanto há um decréscimo dos dois primeiros tipos de conexinas, a expressão da Cx43 aumenta cerca de 10 vezes no terceiro dia de cultura (LEE et al., 1997). Já a Cx46 aparece por volta do sexto dia de cultura e é considerado o marco para se caracterizar a transição dos APTII em direção a APTI (ABRAHAM et al., 1999).

Também tem sido demonstrado que em tumores pulmonares, tanto de seres humanos quanto os induzidos quimicamente em animais de laboratório, a Cx43 apresenta baixa expressão ou apresenta alteração em sua localização sub-celular, implicando diretamente na diminuição da capacidade de comunicação das células tumorais. Um resumo deste estudo é apresentado nas tabelas 10 e 11. 
Tabela 10 - Capacidade de comunicação e expressão da Cx43 em linhagens de células derivadas de carcinoma humano, NHBEC a SAEC*

\begin{tabular}{|c|c|c|c|c|}
\hline \multirow{2}{*}{$\begin{array}{l}\text { Linhagem } \\
\text { celular }\end{array}$} & \multicolumn{4}{|c|}{ Expressão da $\mathrm{Cx} 43^{1}$} \\
\hline & GJIC (\%) & RNAm & Proteína & Imunoistoquímica ${ }^{2}$ \\
\hline \multicolumn{5}{|c|}{ Não transformada } \\
\hline NHBEC & $95,3 \pm 2,2$ & ++ & ++ &,$+++ p$ \\
\hline SAEC & $90,9 \pm 2,6$ & ++ & ++ &,$+++ p$ \\
\hline \multicolumn{5}{|c|}{ Carcinoma de pequenas células } \\
\hline $\mathrm{NCl}-\mathrm{H} 360$ & $48,6 \pm 9,7$ & +++ & ++ & ND \\
\hline $\mathrm{NCl}-\mathrm{H} 446$ & $2,7 \pm 1,0$ & ND & ND & - \\
\hline \multicolumn{5}{|c|}{ Carcinoma de células escamosas } \\
\hline $\mathrm{NCl}-\mathrm{H} 226$ & $11,6 \pm 4,8$ & ND & ND & $+, p, c$ \\
\hline $\mathrm{NCl}-\mathrm{H} 520$ & $5,1 \pm 2,1$ & - & - & - \\
\hline $\mathrm{NCl}-\mathrm{H} 1264$ & $72,3 \pm 10,7$ & ++ & ++ & $++, p, c$ \\
\hline \multicolumn{5}{|c|}{ Adenocarcinoma } \\
\hline $\mathrm{NCl}-\mathrm{H} 23$ & $81,0 \pm 6,2$ & + & ND &,$++ p$ \\
\hline $\mathrm{NCl}-\mathrm{H} 125$ & $2,3 \pm 1,3$ & - & - & - \\
\hline $\mathrm{NCl}-\mathrm{H} 292$ & $4,4 \pm 2,4$ & - & - & - \\
\hline $\mathrm{NCl}-\mathrm{H} 441$ & $4,7 \pm 1,7$ & - & ND & - \\
\hline $\mathrm{NClH} 522$ & $92,6 \pm 3,2$ & +++ & +++ & $+++, p, c$ \\
\hline $\mathrm{NCl}-\mathrm{H} 596$ & $11,8 \pm 2,2$ & + & + &,$+ \mathrm{n}$ \\
\hline \multicolumn{5}{|c|}{ Carcinoma de grandes células } \\
\hline $\mathrm{NCl}-\mathrm{H} 460$ & $40,3 \pm 5,2$ & +++ & +++ &,$+ p$ \\
\hline $\mathrm{NCl}-\mathrm{H} 661$ & $84,9 \pm 3,2$ & ++ & ++ &,$+++ p$ \\
\hline NCl-H1299 & $2,5 \pm 2,4$ & - & - & - \\
\hline $\mathrm{NCl}-\mathrm{H} 1334$ & $2,1 \pm 2,0$ & - & - & - \\
\hline NCl-H1915 & 0 & + & + & ND \\
\hline $\mathrm{NCl}-\mathrm{H} 2009$ & $6,1 \pm 3,2$ & + & + &,$++ \mathrm{C}$ \\
\hline
\end{tabular}

* Adaptado de Cesen-Cummings et al. (1998).

${ }^{1} \mathrm{~A}$ expressão da $\mathrm{Cx43}$ é designada como alta $(+++)$, moderada $(++)$, baixa $(+)$, nenhuma $(-)$ e não determinada (ND).

${ }^{2} \mathrm{~A}$ imunoistoquímica da $\mathrm{C} \times 43$ é designada como alta $(+++)$, moderada $(++)$, baixa $(+)$, nenhuma $(-)$, membrana plasmática (p), citoplasma (c), nuclear (n) e não determinada (ND). 
Tabela 11 - Capacidade de comunicação e expressão da Cx43 em linhagens de células derivadas de carcinoma de pulmão de camundongos e uma linhagem de células epiteliais não transformada de pulmão de camundongo.

\begin{tabular}{lccc}
\hline Linhagem celular $^{1}$ & Expressão da Cx43 & & \\
\cline { 2 - 4 } & GJIC (\%) & RNAm & Proteína \\
\hline Não transformada & & +++ & +++ \\
E10 & $92,5 \pm 2,5$ & & \\
Carcinoma de pulmão & & + & + \\
E9 & $20,5 \pm 2,4$ & + & ++ \\
$82-132$ & $37,3 \pm 1,1$ & +++ & + \\
LM1 & $10,5 \pm 1,1$ & + \\
LM2 & $3,4 \pm 1,5$ & + \\
PCC4 & $3,0 \pm 2,5$ & + & + \\
\hline
\end{tabular}

${ }^{*}$ Adaptado de Cesen-Cummings et al. (1998).

${ }^{1}$ E10 (linhagem de células epiteliais do tipo II não transformada de pulmão de camundongo); E9 (transformante espontânea derivada da linhagem E10); 82-132 (derivado de tumor sólido de pulmão induzido transplacentalmente pela etilnitrosuréia); LM1 e LM2 (derivado de tumores de pulmão sólido e papilífero induzido pela uretana, respectivamente); e PCC4 (derivado de tumor de pulmão papilífero).

${ }^{2} \mathrm{~A}$ expressão da $\mathrm{Cx} 43$ é designado como alta $(+++)$, moderada $(++)$, baixa $(+)$, nenhuma $(-)$ e não determinada (ND).

Um trabalho mais recente com a participação do Dr. Klaus Willecke (YOON et al., 2004), utilizando camundongos Cx32KO, falhou em mostrar quaisquer aumentos na quantidade de lesões pulmonares induzidas pelo metabolismo do benzeno após 26 semanas de experimentação. Foram observados apenas casos de pneumonia e hiperplasia das APTII. Não foi mencionada no trabalho a hipótese de outras conexinas poderem substituir a Cx32 nestes animais. Por outro lado, estudos com o mesmo camundongo realizados por King e Lampe (2004a; 2004b) mostram que a influência da Cx32 na carcinogênese pulmonar é um tanto dúbia e dependente do estímulo utilizado. Tais pesquisadores evidenciaram a importância da Cx32 in vivo 
para o desenvolvimento de neoplasias pulmonares, mas, no entanto, seus resultados são inconclusivos devido à pequena quantidade de animais utilizados nos experimentos.

Assim, correlacionando todas as publicações envolvendo junções comunicantes, conexinas e pulmão até o momento, a Cx43 é, portanto, considerada a principal conexina expressa no pulmão (BEYER et al., 1989). Também corroborando com está observação, Zhang et al. (1998), transfectaram células PG, derivadas de carcinoma humano, com o gene da Cx43. Após a transfecção, estas células apresentaram altos níveis da proteína e revelaram aumentada sua capacidade de comunicação. Juntamente com isso, verificou-se redução na taxa de proliferação, inibição na formação de colônias em ágar soft e também inibição da tumorigenicidade in vivo. Também, como Referênciado, a expressão da Cx43 está correlacionada há uma reversão do fenótipo neoplásico de maneira mais acentuada que a que se observa após a transfecção da Cx32 em células E-9 de tumor de pulmão (CESEN-CUMMINGS et al., 1998).

Com o advento da engenharia genética e a criação de animais transgênicos, uma nova era de descobertas iniciou-se, na qual o defeito genético é conhecido, e se torna possível estudar suas conseqüências no comportamento do animal ou do órgão. Os camundongos transgênicos e os knockouts têm contribuído para elucidar aspectos da biologia e patologia de vários órgãos, como o fígado (DAGLI et al., 2000) e outros (WARD et al., 2000). O camundongo knock-out para a Cx43 (REAUME et al., 1995) constitui uma ferramenta potencial para se entender o papel desta conexina in vivo nos órgãos onde se considera que sua expressão é a principal, i.e., coração, músculo, cérebro, pulmão e outros órgãos (BEYER et al., 1987). Como apresentado na tabela 8, o pulmão é um dos órgãos que ainda não foi 
abordado nos camundongos nocautes para a Cx43. Portanto, neste estudo, pretendeu-se utilizar os camundongos $\mathrm{C} \times 43^{+/-}$. A conexina 43 é a principal conexina presente na musculatura cardíaca, e camundongos $\mathrm{C} \times 43^{-/-}$morrem imediatamente após o nascimento (REAUME et al, 1995). Relata-se que camundongos Cx43 ${ }^{+/-}$ apresentam apenas $50 \%$ da expressão da conexina 43 na musculatura cardíaca (LERNER et al., 2000). Um dos objetivos desta tese foi o de caracterizar as células pulmonares de camundongos $\mathrm{C} \times 43^{+/-}$quanto à expressão da conexina 43 , e também das conexinas 46, 32 e 26, descritas igualmente nesse epitélio (ABRAHAM et al., 1999; LEE et al., 1997). Neste projeto, pretendeu-se avaliar a incidência espontânea de lesões neoplásicas em pulmões de camundongos $\mathrm{C} \times 43^{+/-}$. Pretendeu-se, ainda, estudar a incidência de neoplasmas quimicamente induzidos em camundongos $\mathrm{C} \times 43^{+/-}$, quando comparados aos selvagens $\left(\mathrm{C} \times 43^{+/+}\right) . \mathrm{O}$ modelo de carcinogênese química pulmonar utilizada foi o da uretana, classicamente utilizado em estudos de carcinogênese em camundongos e já utilizado em outros estudos realizados no Brasil (CURY et al., 2000; REYMÃO et al., 1997).

O câncer é uma doença relativamente comum no mundo, cujo conhecimento molecular da patologia muito se avançou, porém, em alguns casos, a cura "ainda" é impossível. Nos países desenvolvidos, atualmente e em média, cerca de uma em cinco pessoas morrem de câncer. Esta proporção nos países em desenvolvimento é de uma morte para cada 15 indivíduos, porém deve-se considerar a faixa etária mais jovem das populações destes países. Um recente estudo estatístico mostrou que o câncer de pulmão, juntamente com o de mama, foram, respectivamente em homens e mulheres, as principais causa de morte por câncer entre a década de 1980-1995 no Brasil, sendo a região Sul e Sudeste do país as de maior acometimento (FILHO; MONCAU, 2002). Dados de estimativa de um grupo de estudo mundial de doenças 
colocam o câncer de pulmão como a décima causa geral de óbito na população mundial e a primeira por câncer em 1990, com a perspectiva de vir a ser a quinta causa geral de óbito no ano de 2020. Extrapolar os dados obtidos em camundongo para seres humanos, os principais beneficiários do conhecimento científico, é utópico. No entanto, ainda hoje os camundongos têm-se mostrado um excelente modelo, se não o mais versátil, para o estudo do câncer e de agentes antineoplásicos. Desta forma, consideramos importantes quaisquer tentativas de elucidar fatores que contribuam para seu desenvolvimento, e, principalmente, os que venham auxiliar futuramente no seu controle. 


\section{OBJETIVOS}

\subsection{OBJETIVO GERAL}

studar a importância da Cx43 no desenvolvimento de neoplasmas pulmonares espontâneos e induzidos quimicamente pela uretana em camundongos.

\subsection{OBJETIVOS ESPECÍFICOS}

a. Avaliar a susceptibilidade de camundongos $\mathrm{C} \times 43^{+/-}$ao desenvolvimento de neoplasmas pulmonares espontâneos e quimicamente induzidos pela uretana.

b. Estudar a capacidade de proliferação por PCNA dos adenomas pulmonares em camundongos $\mathrm{Cx} 43^{+/-}$e $\mathrm{Cx} 43^{+/+}$.

c. Avaliar a expressão dos genes que codificam para as conexinas $43,26,32$, e 46 por meio de western blot, imunoistoquímica e Real Time PCR em adenomas e em tecido pulmonar livre de lesões em camundongos $\mathrm{C} \times 43^{+/-}$e $\mathrm{Cx} 43^{+/+}$.

d. Estudar a expressão, localização e a capacidade de comunicação e proliferação das células do epitélio pulmonar do tipo II em cultura primária. 


\section{MATERIAL E MÉTODOS}

\subsection{ESTUDOS IN VIVO REALIZADOS NA FMVZ-USP}

\subsubsection{Camundongos}

A ruptura do exon2 do gene da conexina 43 foi produzida pela inserção de um gene (neo) que confere resistência a neomicina através da técnica de recombinação homóloga há uma década atrás (REAUME et al; 1995). Os camundongos geneticamente modificados utilizados em nossos experimentos são provenientes da International Agency for Research on Cancer (IARC), Lyon, França. Esses camundongos possuíam originalmente background genético da linhagem C57BL/6, os quais foram cruzados com camundongos CD1, gerando camundongos heterozigotos $\left(\mathrm{C} \times 43^{+/-}\right)$, com background genético da linhagem CD1. Como os camundongos nulo-zigotos para $\mathrm{C} \times 43\left(\mathrm{C} \times 43^{-/-}\right)$morrem ao nascer devido à má formação cardíaca, foram utilizados camundongos $\mathrm{C} \times 43^{+/-}$e selvagens $\left(\mathrm{C} \times 43^{+/+}\right)$.

Camundongos machos $\mathrm{C} \times 43^{+/+}$foram cruzados com fêmeas $\mathrm{C} \times 43^{+/-}$ou machos $\mathrm{Cx} 43^{+/-}$foram cruzados com fêmeas $\mathrm{Cx} 43^{+/+}$no Biotério do Departamento de Patologia da Faculdade de Medicina Veterinária e Zootecnia da Universidade de São Paulo (FMVZ/USP). Todos os camundongos foram mantidos em gaiolas de polipropileno nas dimensões de $30 \times 20 \times 13$ e de $49 \times 34 \times 16$, com filtro em sua parte superior, para lotes de 5 e 20 camundongos, respectivamente. As gaiolas encontravam-se forradas com cama de maravalha de pinus autoclavada. A maravalha era trocada em intervalos de 2 e 3 dias. A ração comercial para camundongos, da marca Nuvilab-CR1, e água filtrada e autoclavada foram 
fornecidas ad libitum, durante todo o período experimental. Os camundongos ficaram alojados separadamente em uma sala do Biotério do Departamento de Patologia, de acordo com as normas da Comissão Interna de Biossegurança da FMVZ/USP para a manutenção de camundongos geneticamente modificados. A sala possui controle de temperatura $\left(22^{\circ} \mathrm{C} \pm 2^{\circ} \mathrm{C}\right)$ e de umidade relativa do ar (45 a $\left.65 \%\right)$. A iluminação dessa sala foi controlada por temporizador com ciclo de 12 horas de claro e 12 horas de escuro. A inspeção dos camundongos foi acompanhada diariamente.

\subsubsection{Identificação dos camundongos}

Os camundongos foram desmamados com 27-28 dias de idade. No momento do desmame, os camundongos receberam marcação padrão de identificação nas orelhas, utilizando-se furador de orelha. O esquema de marcação para identificação é apresentado no apêndice (Apêndice 9A).

\subsubsection{Genotipagem dos camundongos}

\subsubsection{Extração de DNA da cauda dos camundongos}

A técnica utilizada é uma modificação dos tradicionais protocolos utilizados na biologia molecular, a qual confere concomitantemente rapidez de extração e boa qualidade ao DNA. Assim, os fragmentos de cauda coletados durante o desmame, ou seja, aos 27-28 dias de idade, foram mantidos em nitrogênio líquido e transferidos para freezer $-80^{\circ} \mathrm{C}$ até análise. Os fragmentos da cauda ainda congelados foram macerados para facilitar a exposição à proteínase $\mathrm{K}$. Todo o 
procedimento foi realizado à $4^{\circ} \mathrm{C}$. Após esta etapa, o tecido foi transferido para um tubo plástico com tampa (eppendorf) de $1,5 \mathrm{ml}$ contendo $200 \mu \mathrm{l}$ de tampão de lise pH 8,0, acrescido de proteínase $\mathrm{K}$, na proporção de $1,5 \mathrm{mg} / \mathrm{ml}$ (Life Technologies ${ }^{\circledR}$ ). A composição do tampão de lise pode ser observada no quadro 1.

\begin{tabular}{c}
\hline Tampão de Lise \\
\hline Tris $\mathrm{HCl} 50 \mathrm{mM} \mathrm{pH} \mathrm{8,0}$ \\
EDTA $10 \mathrm{mM} \mathrm{pH} \mathrm{8,0}$ \\
$\mathrm{SDS} 0,5 \%$ \\
$\mathrm{H}_{2} \mathrm{O}^{\infty}$ \\
Proteinase $\mathrm{K} 1,5 \mathrm{mg} / \mathrm{ml}$ \\
\hline $\mathrm{H}_{2} \mathrm{O}^{\infty}:$ água MiliQ.
\end{tabular}

Quadro 1 - Composição do tampão de lise

Para otimizar a lise celular, o macerado foi mantido em banho-maria à $65^{\circ} \mathrm{C}$ durante 1 hora (temperatura de atividade ótima da enzima). Após o período de incubação adicionou-se $200 \mu$ do tampão de lise, $\mathrm{pH}$ 8,0, sem o acréscimo de proteinase K. Esta suspensão foi mantida em temperatura ambiente durante 15 minutos. Posteriormente, procedeu-se à centrifugação a $11.000 \mathrm{rpm}$, à $20^{\circ} \mathrm{C}$ por 20 minutos. Para a precipitação do DNA uma alíquota de $400 \mu \mathrm{l}$ do sobrenadante foi acrescida de $760 \mu \mathrm{l}$ de etanol absoluto e de $60 \mu \mathrm{l}$ de acetato de sódio 3M. O DNA precipitado foi lavado em etanol $70 \%$, diluído em $200 \mu$ de tampão TE pH 7,5 (Tris $\mathrm{HCl} 10 \mathrm{mM}$ acrescido de EDTA $1 \mathrm{mM}$ ) e mantido à $4^{\circ} \mathrm{C}$ até a amplificação. A solubilização do DNA foi realizada à $65^{\circ} \mathrm{C}$ por 30 minutos e a quantificação a 260/280nm foi efetuada utilizando a amostra numa diluição de 1:20. 
4.1.2.2 As condições de amplificação dos produtos de PCR

Utilizou-se de 1,5 unidades de Taq Polimerase Platinum (Invitrogen), dNTP 0,2 mM e $\mathrm{Mg}^{+2}$ 1,5 mM, diluídas em tampão de corrida 10X (Quadro 2).

\begin{tabular}{cc}
\hline Componente & Concentração \\
\hline Tris HCl & $1 \mathrm{M}$ \\
$\mathrm{Na}_{2}$ EDTA & $20 \mathrm{mM}$ \\
Ácido Bórico & $1 \mathrm{M}$ \\
\hline
\end{tabular}

Quadro 2 - Tampão de corrida 10X (TEB)

Para a amplificação dos fragmentos de DNA em cada análise aplicou-se 100ng de DNA. Os primers utilizados foram adquiridos da Life Technologies do Brasil Ltda, aliquotados e utilizados conforme a necessidade na concentração de 0,5mM. Os primers para os genes da Cx43 e para o gene neo foram: Cx43 senso 5'CCCCACTCTCACCTATGTCTCC3' e anti-senso 5'ACTTTTGCCGCCTAGCTATCC C3'; NEO senso 5'GGCCACAGTCGATGAATCCAG3' e anti-senso 5'TATCCATCATGGCTGATGCAA3' (YAMAKAGE et al.,1998). A reação da polimerase em cadeia (PCR) foi realizada com os seguintes parâmetros: durante 1 ciclo, na condição de $94^{\circ} \mathrm{C}$ por 2 minutos, 35 ciclos a $94^{\circ} \mathrm{C}$ por 30 s, $55^{\circ} \mathrm{C}$ por 1 minuto, $72^{\circ} \mathrm{C}$ por 4 minutos, 1 ciclo a $72^{\circ} \mathrm{C}$ por 4 minutos e 1 ciclo a $4^{\circ} \mathrm{C}$ por 60 minutos.

O gel de agarose foi preparado na concentração 1,5\% diluído em tampão TBE e submetido a um campo elétrico de $70 \mathrm{~W}$ por 40 minutos para fracionamento do 
DNA. O gel foi corado por 15 minutos com brometo de etídeo (10 mg/ml). Os genes da Cx43 (520 bp) e neo (294 bp) amplificados foram fotografados no aparelho IMAGE MASTER PLUS ${ }^{\circledR}$ (Amersham Biotec).

\subsubsection{Modelo de carcinogênese pulmonar}

Este experimento foi idealizado para verificar se camundongos $\mathrm{Cx} 43^{+/-}$ apresentavam maior susceptibilidade ao desenvolvimento de neoplasias pulmonares. Para tanto, os camundongos foram tratados com o carcinógeno uretana, um derivado do éster do ácido carbâmico como descrito na introdução. Neste experimento, 180 camundongos foram separados em 8 grupos (machos, fêmeas, $\mathrm{Cx} 43^{+/-}$ou $\mathrm{Cx} 43^{+/+}$, respectivamente), previamente tratados com uretana ou não, aos 15/17 dias de idade. O modelo de carcinogênese pulmonar teve a duração de25 semanas (6 meses).

Em nosso experimento, os camundongos foram tratados com uma dose de $3 \mathrm{~g} / \mathrm{kg}$ de uretana $\left(\right.$ Sigma $\left.^{\circledR}\right)$. A administração da uretana foi realizada mediante utilização de equipamentos de proteção individual (EPIs) como aventais, luvas, óculos e máscara. A solução foi preparada de forma a não deixar resíduos (sobras). A droga foi diluída em solução salina autoclavada $\left(25^{\circ} \mathrm{C}\right)$ e administrada intraperitonealmente por meio de duas injeções de $1,5 \mathrm{~g} / \mathrm{kg}$, com intervalos de 48 horas. Esta dose foi selecionada com base no trabalho de Reymão et al. (1997), estudo o qual mencionava que esta é a máxima dose a ser utilizada em camundongos sem provocar a morte, e que promove o desenvolvimento de nódulos pulmonares identificáveis após um tempo mínimo de 60 dias. Durante a aplicação da uretana constatou-se a morte de $6,07 \%$ dos camundongos. Após a injeção do 
carcinógeno, os camundongos eram colocados sobre uma bolsa de água mantida à $40^{\circ} \mathrm{C}$ para evitar a mortalidade por hipotermia. Para todos os grupos experimentais, tanto os camundongos que morreram após a injeção quanto os que morreram no transcorrer do experimento, não foram substituídos.

Decorridas 25 semanas após a injeção do carcinógeno, os camundongos foram anestesiados com tiopental sódico (250 mg/Kg, i.p.) e sacrificados por secção da aorta caudal.

Após o sacrifício, foi realizada a abertura da pele, musculatura abdominal, do diafragma e do tórax e os órgãos foram expostos. Para a retirada dos pulmões, seguiu-se o protocolo indicado pelo Dr. Jerrold Ward (National Cancer Institute, $\mathrm{NCl}$, EUA). A traquéia foi seccionada e posteriormente, uma agulha foi introduzida entre os anéis de cartilagem. Cuidadosamente, cerca de $4,5 \mathrm{ml}$ do fixador methacarn $(60 \%$ Clorofórmio, 30\% Metanol e 10\% Ácido Acético) foi instilado para insuflar e fixar os pulmões coletados. Segundo a experiência do Laboratório de Oncologia Experimental, os melhores resultados de marcação por imunoistoquímica são obtidos utilizando este fixador, além de se preservar o conteúdo de DNA e RNA total.

Com o tecido ainda fresco, foi feita a contagem do número de nódulos em cada lobo pulmonar. Para a preparação dos blocos histológicos em parafina, os pulmões foram separados das estruturas associadas à estrutura pulmonar, como o coração, o timo, etc. Uma parte da traquéia foi preservada para avaliação microscópica dos nódulos. Antecedendo a manipulação, os tecidos foram retirados e lavados em PBS gelado. Todo o processamento do material foi realizado no aparelho Histotécnico (Leica $\left.{ }^{\circledR}\right)$. A coloração foi feita com H\&E. 
4.1.3.1 Quantificação das lesões pulmonares em cortes histológicos de pulmão

Para a quantificação das lesões pulmonares, foram utilizadas lâminas histológicas de pulmões inteiros (whole lung) foram posicionados dorsalmente no bloco de parafina. Foram efetuados cortes histológicos em que a traquéia e os brônquios podiam ser visualizados. Os cortes histológicos assim obtidos, oriundos de pulmões de camundongos fêmeas ou machos, $\mathrm{C} \times 43^{+/-}$ou $\mathrm{C} \times 43^{+/+}$, foram submetidos a exame morfométrico em sistema de análise de imagem computadorizado. O sistema utilizado foi o Image Pro-Plus (Leika). Uma vez calibrado o sistema, cada lesão pulmonar foi delimitada por um cursor (manipulada com o próprio mouse do computador), e imediatamente após este procedimento a área da lesão era calculada pelo sistema. Determinou-se o número de lesões por corte de pulmão, e a área média das lesões de cada pulmão. Em seguida, a área média das lesões do grupo foi obtida. As médias dos quatro grupos foram comparadas utilizando-se a Análise de Variância (ANOVA), estabelecendo-se o nível de significância em 5\%.

\subsubsection{Western blot para conexinas $26,32,43$ e 46}

\subsubsection{Princípio da técnica}

Esta técnica permite a detecção de uma proteína de interesse em um homogenato celular com a ajuda de anticorpos específicos. As proteínas são separadas segundo seu tamanho em um gel de poliacrilamida sob condições desnaturantes (SDS-PAGE), seguidas de transferência para uma membrana de 
nitrocelulose ou de náilon (PVDF). A proteína de interesse é em seguida revelada graças a anticorpos primários específicos, que serão eles mesmos, reconhecidos por anticorpos secundários conjugados a fosfatase alcalina (no caso de experimentos realizados na Université de Poitiers) ou a peroxidase (realizada no laboratório de Oncologia Experimental da FMVZ-USP). Estas enzimas permitem a catalise de uma reação gerando complexos coloridos que podem ser diretamente reconhecidos sobre a membrana.

A Cx43, por exemplo, apresenta vários perfis (varias bandas de peso moleculares diferentes) segundo o tecido de origem ou de tratamentos farmacológicos utilizados, para revisão (SAEZ et al., 1997). As conexinas são amplamente distribuídas entre as diferentes espécies animais e têm sua expressão associada a determinados órgãos (KUMAR, 1996). Dessa forma, na padronização das conexinas que foram determinadas neste experimento, adotou-se o fígado como referêncial de expressão para a Cx26 e Cx32. Já para a Cx43, o coração foi utilizado como referêncial ou células IAR20; e HeLa transfectada com Cx46 foi utilizada como controle positivo para esta Cx.

Para tanto, $40 \mathrm{mg}$ de cada tecido, previamente acondicionado à $-80^{\circ} \mathrm{C}$ foi submetido à lise celular através de homogeneização no Tissue Teator $^{\text {tu }}$ na velocidade máxima. Todas as etapas foram realizadas com as amostras mantidas à $4^{\circ} \mathrm{C}$. A homogeneização foi realizada em Tris- $\mathrm{HCl} 1 \mathrm{M}, \mathrm{pH} 6,8$, contendo SDS $10 \%$ e glicerol $10 \%$ e, então, centrifugado à 15000 rpm por 1 minuto. O sobrenadante foi retirado e acrescido de Tris- $\mathrm{HCl} 1 \mathrm{M}$, pH 6,8; contendo SDS 10\%; glicerol 10\%; DTT 1M; e PMSF 10 mM, centrifugando a amostra à 13000 rpm por 15 minutos. O sobrenadante foi retirado e conservado à $-80^{\circ} \mathrm{C}$ até análise. A concentração de proteína total foi estimada com o reagente BioRad Protein Assay (Bio-Rad Labs., 
Hercules, CA). Na eletroforese utilizou-se $150 \mu \mathrm{g}$ de proteína acrescida de azul de bromofenol, separada em SDS-PAGE a 10\%. A eletroforese foi realizada a $40 \mathrm{~W}$ por um período de 5 horas. Como marcador de peso molecular utilizou-se $10 \mu$ do Kaleidoscope Padrão Pré-corado (Bio-Rad Labs). Após a eletroforese, as proteínas foram transferidas a $25 \mathrm{~W}$ por 12 horas para uma membrana de PDVF 8,0 x 5,0 $\mathrm{cm}^{2}$ (Tans-Blot SD cell; Bio-Rad Labs), previamente umedecida em metanol por 30 minutos. Posteriormente, a membrana foi lavada 3 vezes, durante 15 minutos, em TTBS $0,2 \%$ contendo Tween 20. A membrana foi incubada em leite desnatado (skim milk) 5\%, diluído em TTBS por 2 horas sob leve agitação a temperatura ambiente. Os excessos de membrana foram cortados, descartados e a membrana incubada por 2 horas, à temperatura ambiente, numa solução de anticorpo primário (Cxs43 ou 26), diluído em TTBS $0,2 \%$ contendo Skim Milk 1\%. Utilizou-se o anticorpo policlonal anti-rabbit diluído 1:100 e 1:500, para as conexinas 43 e 26, respectivamente. A membrana foi lavada em TTBS e o excesso de tampão removido em papel de filtro Watman. Procedeu-se a incubação com o anticorpo secundário anti-mouse conjugado à peroxidase $(1: 1000)$ por 2 horas nas mesmas condições acima citadas. A revelação foi efetuada mergulhando-se a membrana por alguns segundos em uma solução contendo diaminobenzidina (DAB)-níquel acrescido de $20 \mu$ de peróxido de hidrogênio a 30\%. O bloqueio da reação deu-se após o mergulho da membrana em água $\mathrm{MiliQ}^{\circledR}$, a seguir a membrana foi escaneada. 


\subsubsection{Reação da Polimerase em Cadeia registrada em tempo real (Real Time PCR)}

\subsubsection{Extração RNA Total pelo método do Trizol}

Os tecidos foram removidos dos camundongos e imediatamente lavados em PBS $\mathrm{pH} 7,4$ à $4^{\circ} \mathrm{C}$ produzido com água tratada com Dietilpirocarbonato $0,1 \%$ (DEPC), e transferidos para tubos eppendorf de $1,5 \mathrm{ml}$ Rnase free e armezenados à temperatura de $-80^{\circ} \mathrm{C}$ até análise. Cerca de $40 \mathrm{mg}$ de tecidos foram pesados e acrescidos de $500 \mu \mathrm{l}$ de TRIzol e com o auxílio de um bastão plástico estéril foram macerados até solubilização total. O homogenato foi aramazenado a temperatura ambiente durante 5 minutos. Após este período, $100 \mu \mathrm{l}$ de clorofórmio foram adicionados $(200 \mu \mathrm{l}$ para cada $\mathrm{ml}$ de TRIzol), os tubos fechados e agitados vigorosamente por aproximadamente 15 segundos e incubados novamente a temperatura ambiente por 2-3 minutos. As amostras foram centrifugadas por 10 minutos, $10.000 \mathrm{rpm} \mathrm{a} 4^{\circ} \mathrm{C}$.

Enquanto isso, novos tubos foram identificados e acrescidos de $500 \mu$ de isopropanol. Após a centrifugação o sobrenadante foi transferido para os tubos contendo o isopropanol, homogeneizados suavemente e incubados a temperatura ambiente por 15 minutos. As amostras foram novamente centrifugadas por 10 minutos, $10.000 \mathrm{rpm}$ a $4^{\circ} \mathrm{C}$. O sobrenadante foi descartado e o pelete (RNA-Total) solubilizado com $1 \mathrm{ml}$ de álcool $75 \%$. Uma nova centrifugação foi realizada por 5 minutos, $7.000 \mathrm{rpm}$ a $4{ }^{\circ} \mathrm{C}$, o excesso de álcool retirado e o pellet (RNA Total) solubilizado em $200 \mu$ l de água tratada com DEPC. Uma alíquota foi removida para verificar a integridade do RNA em gel de agarose e para quantificação, e o restante 
da solução foi armazenado imediatamente em freezer $-80^{\circ} \mathrm{C}$ até sua utilização. $\mathrm{A}$ análise qualitativa foi realizada em gel de agarose $1 \%$ diluída em TBE 1X. Para tanto, $10 \mu$ do RNA total foi acrescido de 1,5 $\mu$ d do corante Loading Dye 10X e 3,5 $\mu$ l água DEPC e a eletroforese foi realizada durante 60 minutos a $80 \mathrm{~W}$.

\subsubsection{Quantificação RNA total}

Para a quantificação do RNA total a amostra foi diluída 1:5, ou seja, $40 \mu \mathrm{l}$ de $\mathrm{H}_{2} \mathrm{O}$ DEPC foi adicionada de $10 \mu \mathrm{l}$ do RNA total e homogeneizada suavemente. $\mathrm{A}$ quantificação foi realizada no Biofotômetro (Eppendorf) a 260nm. O equipamento foi zerado com água DEPC. A qualidade do RNA total extraído (bandas $18 \mathrm{~S}$ e 28S) foi visualizada em gel de agarose a $2 \%$.

\subsubsection{Tratamento do RNA total com DNAse I}

Para eliminar quaisquer resquícios de DNA remanescente que viessem a interferir na análise gerando falsos positivos, foi utilizado o tratamento com DNAse I. Os tubos foram identificados e deixados em banho de gelo. Com todos os tubos no gelo foi pipetado um volume suficiente para conter $1 \mathrm{ng} / \mu \mathrm{L}$ de RNA total após a RTPCR. As condições de reação encontram-se abaixo:

$1 \mu$ I DNAse I reaction buffer $10 x$

$1 \mu \mathrm{l}$ da enzima DNAse I $(1 \mathrm{U} / \mu \mathrm{l})$

$\mathrm{H}_{2} \mathrm{O}$ DEPC para o volume final de $10 \mu \mathrm{l}$ 
A seguir, os tubos foram mantidos a temperatura ambiente por 15 minutos. Ao término desta incubação, $1 \mu \mathrm{l}$ de EDTA ( $25 \mathrm{mM})$ foi adicionado para bloquear a ação da enzima. Continuando a reação, os tubos foram aquecidos por 10 minutos a $65^{\circ} \mathrm{C}$ no próprio termociclador. Após este período, os tubos foram retirados do termociclador e adicionados em banho de gelo.

\subsubsection{Transcrição Reversa}

Aos tubos contendo RNA total (tratados préviamente com DNAse I), foram adicionados $1 \mu \mathrm{l}$ do Oligo DT; $1 \mu \mathrm{l}$ de dNTPs (mix $10 \mathrm{mM}-2,5 \mathrm{mM}$ de cada dNTP) e incubados a $65^{\circ} \mathrm{C}$ por 5 minutos, retirados da máquina e colocados no gelo. $\mathrm{A}$ seguir, foram acrescentados aos tubos: $4 \mu$ do buffer $5 X$ (superscript II); $2 \mu$ de DTT $1 \mathrm{M} ; 1 \mu \mathrm{l}$ de RNAse OUT e este mix incubado por 2 minutos a $42^{\circ} \mathrm{C}$. Os tubos foram mantidos a $42^{\circ} \mathrm{C}$ e acrescidos de $1 \mu$ da enzima Superscript II. A incubação continuou a $42^{\circ} \mathrm{C}$ por 50 minutos e em seguida a $70^{\circ} \mathrm{C}$ por 15 minutos.

Ao término desta incubação foram acrescentados aos tubos $1 \mu \mathrm{l}$ de enzima RNAse H (para retirar os resíduos de RNA da amostra de cDNA) e incubados a $37^{\circ} \mathrm{C}$ por 20 minutos. O cDNA foi armazenado a $-20^{\circ} \mathrm{C}$ até o momento da amplificação do cDNA. Todos os reagentes e enzimas utilizados eram provenientes da Invitrogem. 
4.1.5.5 PCR em tempo real no ABIPrism ${ }^{\circledR} 7000$ Sequence Detection Systems (Applied Biosystems)

Após a transcrição reversa (RT), foi efetuado o PCR em Tempo Real (Real Time PCR) no aparelho ABIPrism ${ }^{\circledR} 7000$ (Figura 16 A). Neste sistema, as fases de anelamento, extensão e desnaturação ocorrem durante os ciclos de maneira similar quando da utilização do termociclador comum, uma vez que o ABIPrism 7000 é um termociclador acoplado há uma câmera CCD (Figura 16 F). A diferença é que a amplificação da seqüência alvo é detectada em tempo real pela emissão de fluorescência, que ocorre quando há formação de dupla fita na região codificada pelo par de primers (Figura 16 B, C, D e E). A quantificação relativa da amplificação é feita pela fluorescência captada pela unidade óptica do aparelho (Figura 16 F). 

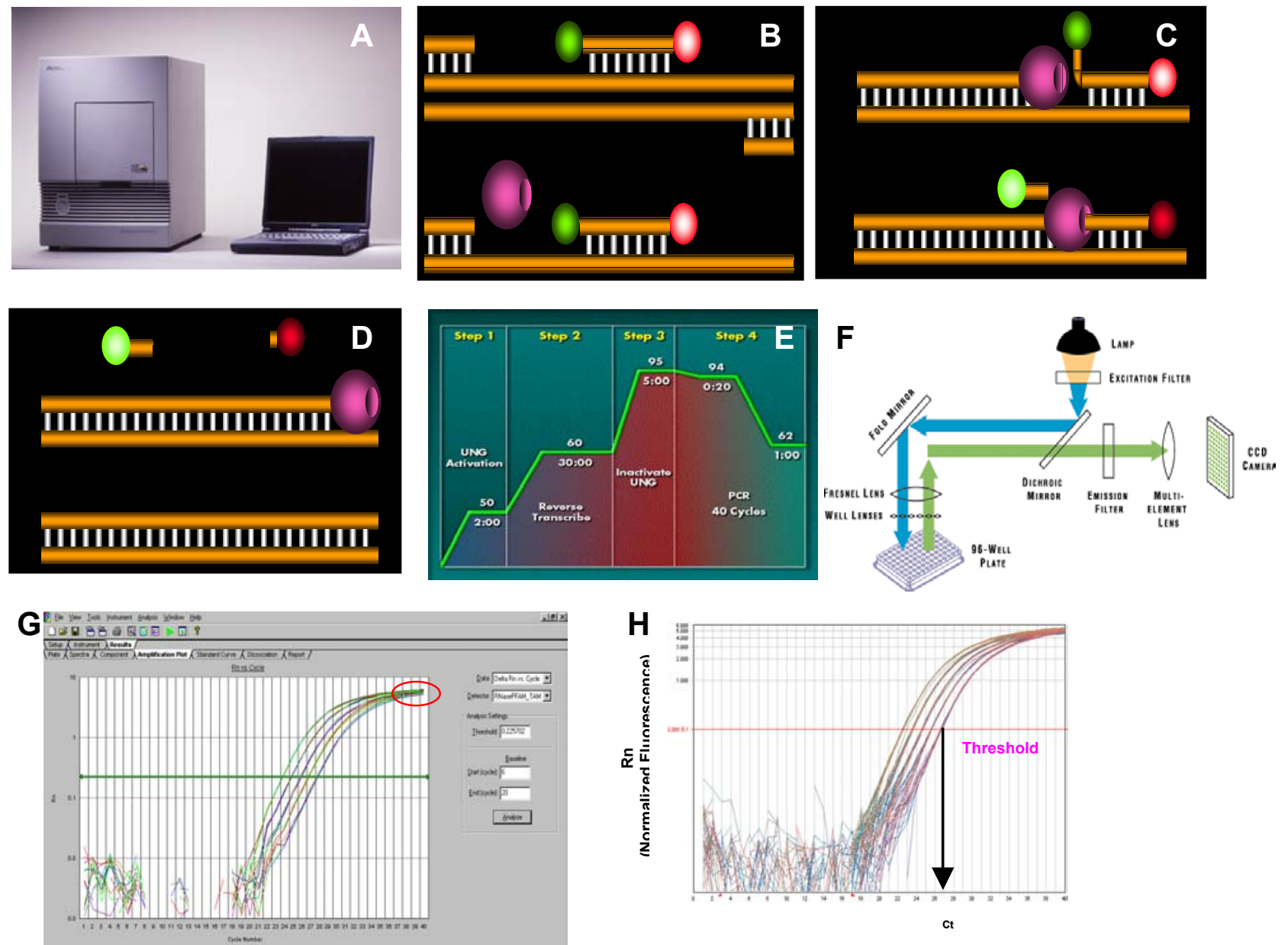

Figura 16 - Esquema geral do PCR em Tempo Real. A. Equipamento ABI Prism ${ }^{\circledR} 7000$. B. Observase os componentes principais da reação em tempo real, os primers ligados, as sondas ligadas a seus respectivos reporter e quencher e a taq polimerase. Para que não seja amplificado DNA genômico é aconselhado pelo fabricante que os mesmos sejam desenhados em éxons diferentes, embora, isto não seja uma regra. C. Início da reação de amplificação, com a extensão dos primers e atividade 5' exonuclease da taq, com liberação do reporter. D. Extensão completa com a liberação completa do reporter. E. Apresentação das etapas do PCR em tempo real. Step 1: ativação da UNG; Step 2: primeira extensão; Step 3: inativação da UNG; Step 4: Desnaturação da dupla fita, ligação da sonda a $70^{\circ} \mathrm{C}$ e dos primers a $60^{\circ} \mathrm{C}$ com extensão dos produtos de PCR. F. Funcionamento do sistema óptico de detecção da fluorescência. G. Resultado de uma titulação de PCR. H. Esquema mostrando o limiar de corte, posicionado na fase exponencial e os seus respectivos Cts (número de ciclo) 
À medida que a reação de amplificação se processa (Figura 16 E), um gráfico é construído (Figura $16 \mathrm{G}$ ). Neste gráfico, a ordenada corresponde ao número de cópias e a abscissa ao número de ciclos. Diferentemente do sistema tradicional de amplificação, onde o que se observa é o número de cópias final (Figura 16 G, círculo vermelho), a amplificação é detectada onde as condições "ótimas" para o PCR são mantidas, ou seja, na fase exponencial. Neste período, os substratos para a amplificação ainda estão presentes nas concentrações ideais, o que no sistema endpoint não se observa. Pelas características do sistema, no PCR real time é possível determinar este perfil de amplificação (Figura $16 \mathrm{H}$ ), o que representa uma das vantagens metodológicas. O ponto na abscissa correspondente ao início do trecho linear é chamado de Ct (cycle threshold = limiar de corte) e este valor é utilizado para a comparação relativa da expressão gênica: quanto menor o $\mathrm{Ct}$, teoricamente mais expressa é determinada mensagem, ou seja, a diferença de $1 \mathrm{Ct}$, representa o dobro de expressão.

O sistema adotado em nosso laboratório para a detecção da expressão gênica das Cxs 26, 32, 43 e 46 foi o sistema TaqMan. Neste sistema, além do par de primers, é necessária a utilização de uma sonda que, por ter um Tm mais alto (cerca de $10^{\circ} \mathrm{C}$ de diferença), se hibridiza de forma específica com a fita template antes do par de primers. A sonda é composta na sua extremidade 5' por fluoróforo R (repórter dye) cuja fluorescência, quando a sonda está integra, é capturada pelo Quencher (NFQ) acoplado ao MGB. O MGB é a substância que permite a construção da sonda com a diferença de $10^{\circ} \mathrm{C}$ em relação ao primer (Figura 17). 


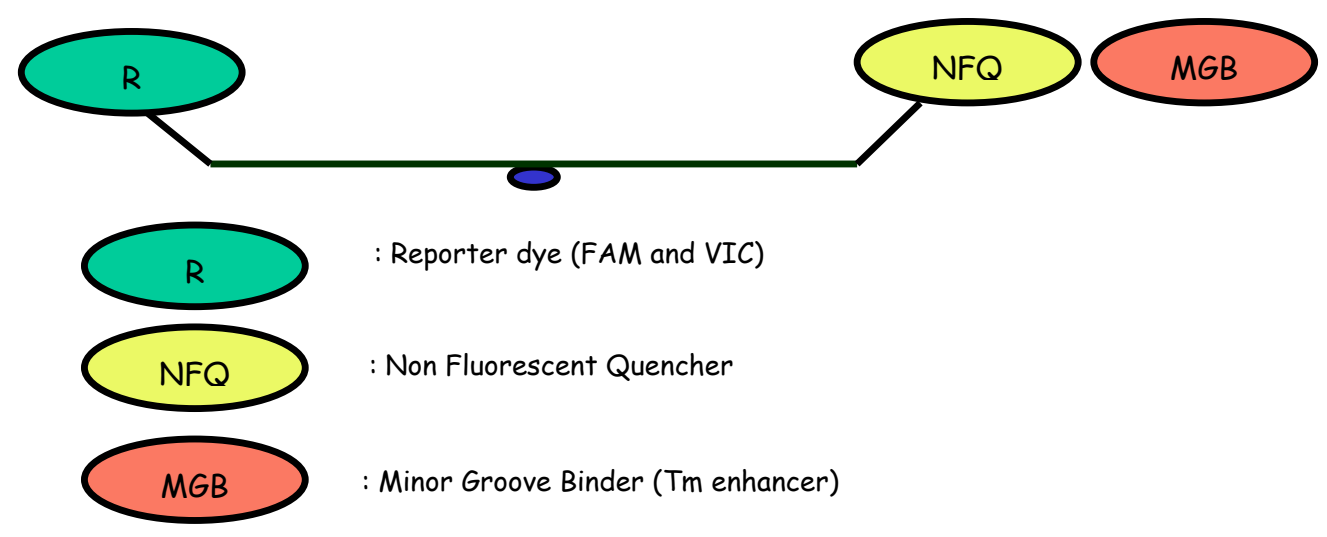

Figura 17 - Esquema representando a sonda fluorescente do sistema TaqMan. Segundo os critérios da Applied Biosystems, o melhor local para a construção da sonda é a junção éxon-éxon. Portanto, sempre que possível este critério foi adotado. No entanto, isto é mais indicado quando não se faz o tratamento com DNAse I. Enquanto unidos, a fluorescência emitida pelo repórter é capturada pelo quencher. Durante a reação a probe é clivada ocorrendo à separação do floróforo e do quencher. Neste instante a fluorescência emitida é registrada pelo equipamento

Através da atividade corretiva 5' exonuclease da Taq polimerase, o flouróforo

é clivado e a fluorescência emitida é captura pela câmera CCD do equipamento. Assim, durante o processo de extensão iniciado pelo par de primers, a sonda se separa da fita template, e nesse momento ocorre à liberação do fluoróforo. Em cada fase de anelamento, o fluoróforo se intercala na dupla fita, liberando a fluorescência que é, portanto, proporcional ao número de cópias.

\subsubsection{Primers e probes}

Os primers e as probes específicas para as Cx43, Cx46, Cx32, Cx26 estão descritos na tabela 12. As seqüências utilizadas para a confecção dos primers foram aquelas depositadas no banco público do NCBI (http://www.ncbi.nlm.nih.gov). Para as Cx43, o primer foward (senso) foi desenhado dentro do éxon 1, enquanto que o primer reverse (anti-senso) foi desenhado dentro do éxon 2. Os primers referentes à Cx32 foram desenhados dentro do éxon 1b (foward) e dentro do éxon 2 (reverse). 
Para a Cx26 e Cx46, as seqüências totais dos éxons 1 ainda não foram decifradas completamente. Desta forma, ambos os primers foram desenhados dentro do éxon 2. Para a Cx46 tanto o primer foward quanto o reverse foram desenhados dentro da carboxila terminal. Os primers e a probe para a Cx26 foram desenhados dentro da alça extracelular E2 codificada pelo éxon 2. Ambas as seqüências foram alinhadas utilizando a ferramenta do NCBI (BLAT) para a confirmação das mesmas. A porção correspondente a cada seqüência foi determinada com o auxílio da ferramenta Swiss-Prot (http://us.expasy.org/cgi-bin/niceprot).

As seqüências enviadas a Applied Biosystems para a construção dos primers estão sublinhados e discriminados abaixo e na tabela 12.

\section{Cx43 exon 1 e exon 2}

TATCAGCACTTTTCTTTCATTGGGGGAAAGGCGTGAGGGAAGTACCCAACAGCA GCAGACTTTGAAACTTTAAACAGACAGGTCTGAGAGCCCGAACTCTCCTTTTCCT TTGACTTCAGCCTCCAAGGAGTTCCACCACTTTGGCGTGCCGGCTTCACTTTCA TTAAGTGAAAGAGAGGTGCCCAGACATGGGTGACTGGAGCGCCTTGGGGAAG CTGCTGGACAAGGTCCAAGCCTACTCCACGGCCGGAGGGAAGGTGTGGCTGTC GGTGCTCTTCATTTTCAGAATCCTGCTCCTGGGGACAGCGGTTGAGTCAGCTTG GGGTGATGAACAGTCTGCCTTTCGCTGTAACACTCAACAACCCGGTTGTGAAAA TGTCTGCTATGACAAGTCCTTCCCCATCTCTCACGTGCGCTTCTGGGTCCTTCA GATCATATTCGTGTCTGTGCCCACACTCCTGTACTTGGCTCACGTGTTCTATGTG

TACATCATCAGCATCCTCTTCAAGTCTGTCTTCGAGGTGGCCTTCCTGC TGATCCAGTGGTACATCTATGGGTTCAGCCTGAGTGCGGTCTACACCTGCAAGA GAGATCCCTGCCCCcacCAGGTGGACTGCTTCCTCTCAcGTCCCACGGA

\section{Cx26 exon 2}

TGCCAACCATCCAGAGGACAAGATGGATTGGGGCACACTCCAGAGCATCCTCG GGGGTGTCAACAAACACTCCACCAGCATTGGAAAGATCTGGCTCACGGTCCTCT TCATCTTCCGCATCATGATCCTCGTGGTGGCTGCAAAGGAGGTGTGGGGAGAT GAGCAAGCCGATTTTGTCTGCAACACGCTCCAGCCTGGCTGCAAGAATGTATGC TACGACCACCACTTCCCCATCTCTCACATCCGGCTCTGGGCTCTGCAGCTGATC ATGGTGTCCACGCCAGCCCTCCTGGTAGCTATGCATGTGGCCTACCGGAGACA $\mathrm{T}$ 
ATCTTCTTCCGGGTCATCTTTGAAGCCGTCTTCATGTACGTCTT TTACATCATGTACAATGGCTTCTTCATGCAACGTCTGGTGAAATGCAACGCTTG GCCCTGCCCCAATACAGTGGACTGCTTCATTTCCAGGCCCACAGAAAAGACTGT CTTCACCGTGTTTATGATTTCTGTGTCTGGAATTTGCATTCTGCTAAATATCACAG AGCTGTGCTATTTGTTCGTTAGGTATTGCTCAGGAAAGTCCAAAAGACCAGTCTA A

\section{Cx32 exon $1 b$ e exon 2}

TTGGGACGCAGGCGCGACCACAGGGACCACTCCCCCTACACAGACATGAGACC ATAGGGGAGCTGTCTGGGTGGCCTCAAGGATAGGCGCTCCCCAG GTGTGAAT GAGGCAGGATGAACTGGACAGGTCTATACACCTTGCTCAGTGGCGTGAATCGG CACTCTACAGCCATTGGCCGAGTATGGCTGTCTGTCATCTTCATCTTCAGAATCA TGGTGCTGGTGGTGGCTGCTGAGAGCGTGTGGGGGGATGAGAAGTCCTCTTTC ATCTGTAACACCCTCCAGCCGGGCTGCAACAGCGTCTGCTATGACCATTTTTTC CCCATCTCCCACGTGCGCCTATGGTCCCTGCAGCTTATCTTGGTTTCCACCCCA GCTCTCCTCGTGGCAATGCACGTA

CTGTGGTGGACCTATGTCATCAGTGTGGTGTT CCGGCTGCTGTTCGAGGCTGTCTTCATGTATGTCTTCTATCTGCTCTACCCCGG CTATGCCATGGTGCGGCTGGTCAAGTGTGAAGCCTTCCCCTGCCCCAACACAG TGGACTGCTTCGTGTCCCGCCCCACCGAGAAAACCGTCTTCACTGTCTTTATGC TCGCAGCCTCCGGCATCTGCATTATCCTCAACGTGGCGGAGGTGGTGTACCTC ATCATCCGGGCCTGTGCCCGCCGTGCTCAGCGCCGCTCCAATCCGCCCTCCCG CAAGGGCTCGGGCTTCGGCCACCGCCTCTCACCTGAATACAAGCAGAATGAGA TCAACAAGCTGCTGAGCGAGCAGGATGGCTCTCTGAAAGACATACTGCGCCGC AGCCCTGGCACAGGGGCCGGGCTCGCTGAAAAGAGCGACCGATGCTCAGCCT GCTGATGCCAGTACCAGGCAACCTCCCATCCCACCCCTCCCTCACCCTGCCCA GACCTGCCCCTCCTTCTCCTATGCCGGTGAGCAGGCTTCTGCCTGATAGGGATT ATTACTCCATCAAACCTTCCCTCCCTTCCTACTCCCCTTCCTCAGAGAGCCTTCT GTCAAAGACCTGGCCGGCTGGGGAGTGGGGAGCCACTTCTACAACAGGGCTCA AGGTTATTAATGGTGTGGGCAATTCTTTCTGCCTATACCCTTTCCTCTTCCСTCT CCCTGAAACGAGGGATGAGATGTTCTGAAGGTGTTTCCAATTAGGAAACTAATC TTAACCCCCATGCTGTCTGGTACCCCACTTTGGGAGTCATGTCGGTGGGGAGG GATGTGGGCAAGCAGAGTGGAGGAGGGGCTCTGCCTTGTGGATGGAGAAGGG ATGGGAGCTTGCCTTGCTGCCTGCCACGGGGGAGAAGAGGACACATCTAGGGT GAGGGAGTTATGGAGAGAGAAGCAGGCAGATAAATCGGAGTGGGGATTGGTCA GGGCTGCCCCCAGTCCCCAGTTCCCAAGGCCCCTCTCTCTG

\section{Cx46 porção 5'UTR e exon 2}

ATGGGCGACTGGAGCTTCCTGGGGCGGCTGCTGGAGAACGCACAGGAGCACT CTACAGTCATCGGCAAAGTGTGGCTGACCGTGCTGTTCATCTTCCGCATTCTGG TGTTAGGGGCGGCAGCCGAGGAGGTGTGGGGCGACGAGCAATCGGACTTCAC CTGCAACACACAGCAGCCAGGCTGTGAGAACGTCTGCTACGACCGCGCTTTCC CCATTTCGCACATCCGCTTCTGGGCGCTGCAAATCATCTTCGTGTCTACGCCCA CCCTCATCTATCTGGGCCACGTGCTACACATC 
TACGTCTTCAACA

TCATCTTCAAGACACTCTTCGAAGTGGGGTTCATCGCGGGCCAGTACTTTCTAT ACGGCTTCCAGCTGCAGCCACTTTACCGCTGCGACCGCTGGCCCTGCCCCAAC ACTGTGGACTGTTTCATCTCCAGGCCCACAGAGAAGACCATCTTTGTCATCTTCA TGCTGGCTGTGGCCTGTGCGTCACTGGTACTCAACATGCTGGAGATTTACCACC TGGGCTGGAAGAAGCTCAAGCAGGGAGTTACTAACCACTTCAACCCAGATGCCT CAGAAGCCAGGCACAAGCCCTTGGACCCCCTACCCACGGCCACCAGCTCTGGC CCGCCCAGCGTCTCCATCGGGTTCCCACCTTATTACACACACCCTGCCTGTCCC ACAGTACAGGCAAAGGCCATAGGGTTTCCTGGGGCCCCACTATCACCAGCAGA CTTCACAGTGGTGACTCTAAACGATGCTCAAGGCAGAAACCACCCAGTCAAACA CTGCAATGGCCACCACCTGACGACAGAGCAGAACTGGACCAGGCAAGTGGCAG AGCAGCAGACTCCAGCCAGCAAGCCCTCTTCAGCAGCATCCAGCCCTGATGGC CGCAAGGGGCTCATTGACAGCAGTGGCAGCAGCTTACAGGAGAGTGCCTTGGT AGTGACGCCAGAGGAGGGGGAACAGGCTTTGGCCACCACAGTGGAGATGCAC

\section{GAPDH}

ACAGCCGCATCTTCTTGTGCAGTGCCAGCCTCGTCCCGTAGACAAAATGGTGAA GGTCGGTGTGAACGGATTTGGCCGTATTGGGCGCCTGGTCACCAGGGCTGCCA TTTGCAGTGGCAAAGTGGAGATTGTTGCCATCAACGACCCCTTCATTGACCTCA ACTACATGGTCTACATGTTCCAGTATGACTCCACTCACGGCAAATTCAACGGCA CAGTCAAGGCCGAGAATGGGAAGCTTGTCATCAACGGGAAGCCCATCACCATC TTCCAGGAGCGAGACCCCACTAACATCAAATGGGGTGAGGCCGGTGCTGAGTA TGTCGTGGAGTCTACTGGTGTCTTCACCACCATGGAGAAGGCCGGGGCCCACT TGAAGGGTGGAGCCAAACGGGTCATCATCTCCGCCCCTTCTGCCGATGCCCCC ATGTTTGTGATGGGTGTGAACCACGAGAAATATGACAACTCACTCAAGATTGTCA GCAATGCATCCTGCACCACCAACTGCTTAGCCCCCCTGGCCAAGGTCATCCATG ACAACTTTGGCATTGTGGAAGGGCTCATGACCACAGTCCATGCCATCACTGCCA CCCAGAAGACTGTGGATGGCCCCTCTGGAAAGCTGTGGCGTGATGGCCGTGG GGCTGCCCAGAACATCATCCCTGCATCCACTGGTGCTGCCAAGGCTGTGGGCA AGGTCATCCCAGAGCTGAACGGGAAGCTCACTGGCATGGCCTTCCGTGTTCCT ACCCCCAATGTGTCCGTCGTGGATCTGACGTGCCGCCTGGAGAAACCTGCCAA GTATGATGACATCAAGAAGGTGGTGAAGCAGGCATCTGAGGGCCCACTGAAGG GCATCTTGGGCTACACTGAGGACCAGGTTGTCTCCTGCGACTTCAACAGCAACT CCCACTCTTCCACCTTCGATGCCGGGGCTGGCATTGCTCTCAATGACAACTTTG TCAAGCTCATTTCCTGGTATGACAATGAATACGGCTACAGCAACAGGGTGGTGG ACCTCATGGCCTACATGGCCTCCAAGGAGTAAGAAACCCTGGACCACCCACCC CAGCAAGGACACTGAGCAAGAGAGGCCCTATCCCAACTCGGCCCCCAACACTG AGCATCTCCCTCACAATTTCCATCCCAGACCCCCATAATAACAGGAGGGGCCTA GGGAGCCCTCCCTACTCTCTTGAATACCATCAATAAAGTTCGCTGCACCCA

Cada cor utilizada representa determinada porção das Cxs onde os primers e as probes fluorescentes foram confeccionadas (para esclarecimentos ver Figura 6 A). Exon 1 da Cx43; 1b da Cx32; Porção 5'UTR; - Extremidades amino e carboxi terminal; - Domínios transmembrana (M1; M2; M3; M4); Alças extracelulares (E1 e E2); Alça intracelular. Seqüências em negrito e itálico representam a probe fluorescente. 
Tabela 12 - Primers, probes e seus respectivos produtos de amplificação

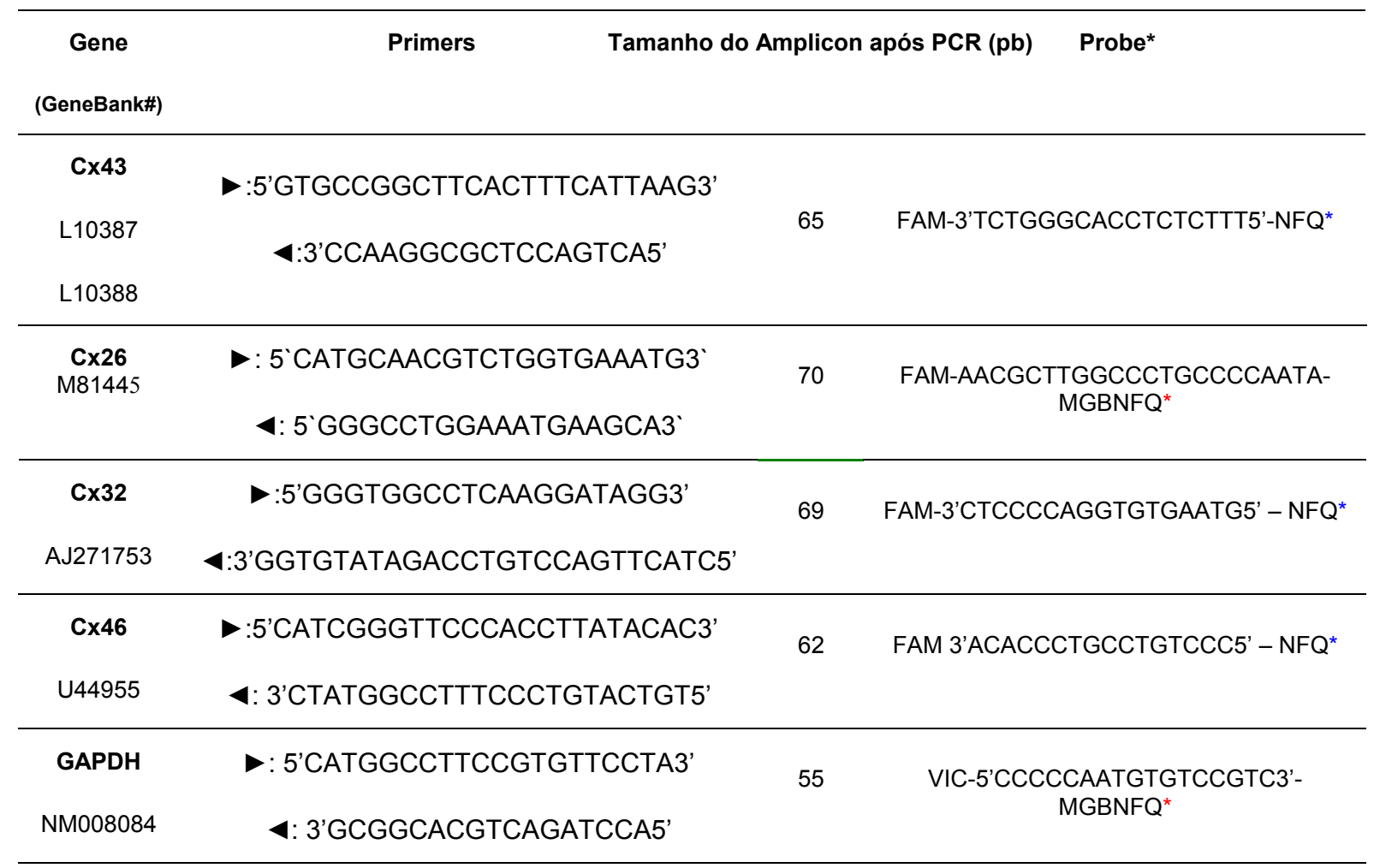

*Carcterísticas de monitoramento dos sinais fluorescentes do sistema 7000 gerados durante o PCR pelos fluoróforos $\mathrm{FAM}^{\mathrm{TM}}$, e VIC ${ }^{\mathrm{TM}}$. MGB = Minor groove binding; NFQ = non-fluorescent quencher; = forward; 4 = reverse. Os primers e probes para a Cx43, Cx32 e Cx46 foram desenhados pelo serviço Assays-by-Design ${ }^{\text {SM }}$ de expressão gênica (Applied Biosystems); GAPDH e Cx26 foram desenhados pelo Custon Oligo Synthesis Service (Applied Biosystems, Foster City, USA). ${ }^{*}$ Assays by design; * Coustom primers 


\subsubsection{Condições da reação de Real Time PCR}

A amplificação dos cDNAs das Cxs no equipamento ABI7000 Sequence Detection seguiu os critérios determinados pelo fabricante do aparelho. Assim, a enzima UNG que corrige quaisquer problemas oriundos da transcrição reversa foi ativada por 2 minutos à $50^{\circ} \mathrm{C}$ e desativada por 10 minutos a $95^{\circ} \mathrm{C}$. A reação da polimerase em cadeia propriamente dita ocorreu em 40 ciclos compreendendo 15 segundos à $95^{\circ} \mathrm{C}$ para a desnaturação das fitas de cDNA seguido de 1 minuto à $60^{\circ} \mathrm{C}$ para extensão. Após este período os dados coletados foram analisados e normalizados.

4.1.5.8 Interpretação dos resultados obtidos no sistema de Real time PCR

4.1.5.8.1 Método comparativo do $2^{-\Delta \Delta C t}$ para a quantificação relativa (LIVAK; SCHIMITTIGEN, 2001)

A quantidade do target, normalizada a um controle endógeno e relativo a um calibrador é dada por:

$$
2^{-\Delta \Delta C t}
$$

\subsection{Derivação da fórmula}

A equação que descreve a amplificação exponencial do PCR é:

$$
X_{n}=X_{o} \times\left(1+E_{x}\right)^{n}
$$


Onde:

$$
\begin{aligned}
& \mathbf{X}_{\mathbf{n}}=\text { número de moléculas alvo no ciclo } \mathrm{n} \\
& \mathbf{X}_{\mathbf{o}}=\text { número inicial de moléculas alvo } \\
& \mathbf{E}_{\mathbf{x}}=\text { eficiência de amplificação de gene alvo } \\
& \mathbf{n}=\text { número de ciclos }
\end{aligned}
$$

O ciclo de corte $(\mathrm{Ct})$ ou threshold (Figura $1 \mathrm{H}$ ) indica o ciclo no qual a quantidade do gene target amplificado atinge um threshold fixado. Assim,

$$
X_{T}=X_{0} X\left(1+E_{x}\right)_{T, X}^{C}=K_{x}
$$

Onde:

$\mathbf{X}_{\mathbf{T}}=$ número do ciclo de corte das moléculas alvo

$\mathrm{C}_{\mathrm{T}, \mathrm{X}}=$ ciclo de corte para o amplicom alvo

$\mathbf{K}_{\mathbf{x}}=$ constante

Uma equação similar para o controle endógeno da reação é;

$$
R_{T}=R_{0} \times\left(1+E_{R}\right)_{T, R}^{C}=K_{R}
$$

Onde:

$\mathbf{R}_{\mathbf{T}}=$ número do limiar de corte das moléculas referências

$\mathbf{R}_{\mathbf{o}}=$ número inicial das moléculas referências

$\mathbf{E}_{\mathbf{R}}=$ eficiência da amplificação da referência

$\mathrm{C}_{\mathrm{T}, \mathrm{R}}=$ ciclo de corte da amplificação da referência

$\mathrm{K}_{\mathbf{R}}=$ constante

Dividindo-se Xt por Rt nos dá a seguinte expressão:

$$
\overline{R_{T}}=\frac{X_{T} \quad X_{0} \times\left(1+E_{x}\right)^{C}{ }_{T} \times K_{0} \times\left(1+E_{R}\right)_{T, R}^{C}}{=}=\frac{K_{x}}{K_{R}}
$$

O exato valor de Xt e Rt dependem de um número de fatores, incluindo:

Reporter dye utilizado na probe; 
O efeito do contexto da seqüência sobre as propriedades de fluorescência da probe;

Eficiência de clivagem da probe;

Pureza da probe;

Ajuste do threshold;

Além do mais, a constante $\mathrm{K}$ não deve ser igual a 1 . Assumindo que a eficiência do target e da referência sejam os mesmos:

$$
E_{x}=E_{R}=E, \quad \frac{X_{o}}{R_{0}} \times(1+E)_{T, X}^{C}-C_{T, X}=K
$$

ou

$$
X_{N} \times(1+E)_{T}^{\Delta C}=K
$$

Onde,

$\mathbf{X}_{\mathbf{N}}=\mathrm{Xo} /$ Ro quantidade normalizada do alvo

${ }^{\Delta C_{T}}=C T, X-C T, R$ diferença entre o número de ciclos do alvo e da referência

Rearranjando os dados, temos a seguinte expressão:

$$
X_{N}=K \times(1+E)^{-\Delta C}
$$

O passo final é dividir o $X_{N}$ por uma das amostras $(q)$ pelo $X_{N}$ do calibrador $(c b)$ :

$$
\frac{X_{N, q}}{X_{N, c b}}=\frac{K x(1+E)^{-\Delta C}{ }_{T, q}}{K x(1+E)^{-\Delta C T, c b}}=(1+E)^{-\Delta \Delta C} T_{T}
$$

$$
\Delta \Delta \mathrm{CT}=\Delta \mathrm{CT}, \mathrm{g}-\Delta \mathrm{CT}, \mathrm{cb}
$$


Para os amplicons desenhados e otimizados de acordo com o fabricante (tamanho do amplicon < 150 pb), a eficiência é próxima de 1. Por conseguinte, a quantidade do target, normalizado a um controle endógeno e a um calibrador relativo é dada por:

$$
2^{-\Delta \Delta C t}
$$

\subsubsection{Imunomarcação para as conexinas $26,32,43$ e 46 nos tecidos fixados}

Os tecidos fixados em parafina foram desparafinizados e re-hidratados. Após a re-hidratação do corte histológico, o tecido foi apresentado ao anticorpo primário policlonal contra Cx43 na diluição de 1:1000 (Chemicon), anticorpos policlonais contra a Cx26 (1:200) e Cx32 (1:500) proveniente da Zymed, e contra a Cx46 (1:1500) com anticorpos cedidos pelo Dr. Michael Koval (Universidade da Pensilvânia, USA), todos permaneceram em contato overnight a $4^{\circ} \mathrm{C}$ em câmara úmida. Anticorpo secundário anti-rabbit 1:1000 (Promega) foi utilizado e deixado em contato por 2 horas a temperatura ambiente. Para a amplificação do sinal, o kit TSA (Perkin-Elmer) foi utilizado. As imagens foram capturadas no microscópio de fluorescência no aumento de 40X. 


\subsubsection{Detecção por PCNA das células em fase $S_{1}$ do ciclo cellular nos diferentes tipos celulares}

Para a quantificação das células em fase $S_{1}$ nas lesões pulmonares, 10 camundongos escolhidos inteiramente ao acaso em cada grupo foram utilizados. Anticorpos primários contra o PCNA (Dako) diluídos 1:3200 foram utilizados, e detectados pelo método da estrepdavidina- biotina- peroxidase. As células positivas foram evidenciadas após a coloração com DAB. Todas as células contidas em três diferentes campos foram contadas, aproximadamente 1000 células no total, e aquelas apresentando os núcleos corados em marrom foram consideradas positivas. A porcentagem de células na fase $S_{1}$ foi obtida dividindo-se o número de células coradas pelo total do número de células contadas em cada campo. As células positivas foram contadas nos tumores sólidos, papilíferos e mistos separadamente.

\subsubsection{Análise estatística}

A avaliação estatística da incidência de lesões pulmonares foi realizada usando-se ANOVA. Valores de $\mathrm{P}<0,05$ foram considerados significantes. 


\subsection{ESTUDOS IN VITRO - ETAPA REALIZADA NA UNIVERSIDADE DE POITIERS/FRANÇA, NO LABORATÓRIO DE BIOMEMBRANAS E SINALIZAÇÃO CELULAR}

\subsubsection{Breve descrição da metodologia da extração dos Pneumocitos Alveolares do Tipo II (APTII)}

O procedimento para a extração e cultivo dos APTII que utilizamos é uma modificação de 3 protocolos recentemente publicados (CORTI et al., 1996; DOBBS et al., 2002; RICE et al., 2002). Primeiramente, as células do tecido pulmonar são dissociadas por digestão enzimática. A enzima chamada de Dispase (BD Biosciences) foi à enzima chave para este propósito. Proteases não específicas podem digerir proteínas intersticiais pulmonares liberando células mesenquimais e reduzir a pureza das APTII, ou ainda, podem digerir importantes proteínas da membrana destas células alterando sua função. Embora a Elastase tenha sido amplamente utilizada para a extração dos APTII em outras espécies, tais como ratos (DOBBS et al., 2002), a variabilidade entre as preparações comerciais da enzima tem sido uma problemática, colocando em xeque a confiabilidade da extração. Ao contrário, a Dispase, cliva especificamente o colágeno do tipo IV e a fibronectina, dois dos principais componentes da membrana basal dos APTII. Por outro lado, ela interage de maneira quase desprezível com o colágeno do tipo I, sendo assim, mais específica que outras enzimas para este propósito. Uma vez que as células foram dissociadas, os macrófagos e linfócitos presentes foram removidos por aderência diferencial em placas cobertas com lgG e as células resultantes cultivadas em meio de cultivo DMEM enriquecido com KGF. 


\subsubsection{Extração dos APTII}

Os camundongos foram anestesiados com Avertina (250-300 $\mu \mathrm{l} / 10$ grama de peso vivo) através de injeção intraperitoneal. A cavidade abdominal foi aberta, os pulmões e a traquéia foram expostos e uma cânula foi introduzida na traquéia para permitir o processo de insuflar e desinflar os pulmões e também permitir a instilação da Dispase. O processo de insuflar e desinflar é essencial para uma boa limpeza da vasculatura pulmonar e eliminação das hemácias que, por ventura, venham a se aderir a IgG interferindo no processo de separação de contaminantes. As hemácias que por ventura continuem na suspensão não representam um problema, uma vez que elas morrem no segundo dia de incubação. A limpeza da vasculatura pulmonar foi realizada através do ventrículo direito aplicando-se $\mathrm{NaCl} 0,9 \%$ na temperatura de $37^{\circ} \mathrm{C}$. O NaCl foi introduzido vagarosamente até se verificar que o fígado se tornava túrgido. Neste momento, a instilação do $\mathrm{NaCl}$ foi interrompida e a artéria abdominal cortada para permitir que o fluxo sanguíneo se dirigisse no sentido do ventrículo para o pulmão e do pulmão para a artéria abdominal. Aproximadamente $10 \mathrm{ml}$ de $\mathrm{NaCl}$, em média, foram necessários para a limpeza total da vasculatura, que continuou até que os pulmões se tornassem completamente livres de hemácias, i.e., passassem da cor rosa para a cor branca.

A quantidade de anestésico utilizada foi calculada para que durante toda a intervenção o animal se mantivesse vivo e com o coração batendo, para auxiliar no bombeamento do $\mathrm{NaCl}$. Após a limpeza, cerca de $3 \mathrm{ml}$ de dispase foi introduzida nos pulmões via traquéia. Imediatamente após a instilação da Dispase, $0,5 \mathrm{ml}$ de agarose $0,1 \%$ na temperatura de $45^{\circ} \mathrm{C}$ foi instilado via traquéia e os pulmões foram cobertos com gelo por um período de 2 minutos. A utilização da agarose foi uma 
alternativa encontrada para impedir que a enzima também atuasse na região dos bronquíolos liberando as células Clara (RICE et al., 2002). Até este ponto o tempo máximo necessário foi de 4 minutos por camundongo. Não é recomendado uma intervenção superior a 7 minutos.

Seguindo o procedimento, os pulmões foram removidos e transferidos para um tubo de $15 \mathrm{ml}$ estéril acrescido de mais $1 \mathrm{ml}$ de dispase, para recobrir os pulmões e evitar o extravasamento. O contato com a enzima foi permitido por um período não mais que 45 minutos, efetuados a temperatura ambiente. Para a remoção dos APTII, os pulmões foram dissociados em placas de cultura de $35 \mathrm{~mm}$ com o auxílio de uma tesoura; reduzindo o tecido pulmonar a fragmentos de cerca de $1 \mathrm{~mm}^{2}$. A ação da enzima foi inibida através de diluição em tampão HEPESDMEM, sem adição de soro, contendo 100 U/ml de DNase I. A adição de DNase I foi uma alternativa para liberar os APTII presos ao DNA presente na extração, o que acarretaria em uma menor eficiência na extração.

Para uma maior eficiência na liberação dos APTII dos alvéolos, o homogenato acima descrito foi aspirado em movimentos up-down, no máximo, por dez vezes com o auxílio de uma pipeta sorológica de $10 \mathrm{ml}$. O fluido resultante foi aspirado e filtrado seqüencialmente através de cell strainers (peneiras) de 100, 40 (BD Bioscience) e $20 \mu \mathrm{m}$ (Millipore) de malha. Após a última filtração, o conteúdo foi centrifugado a 130 g durante 8 minutos a $20^{\circ} \mathrm{C}$. Quando mais que um camundongo era manipulado, após a última filtração, a suspensão sempre foi mantida em banho de gelo. Após a centrifugação, o pellet resultante foi resuspendido em $2 \mathrm{ml}$ de DMEM ainda sem adição de soro fetal bovino e os APTII quantificados em câmara de Malassez (semelhante à de Newbawer). Estas células ( $1 \mathrm{ml}$ dividido em duas placas) foram depositadas em placas de cultura não tratadas (placas para o cultivo de bactérias). 
No entanto, estas placas tinham sido pré-tratadas com lgG $500 \mu \mathrm{g}$ por 3 horas, e imediatamente incubadas por 1 hora a $37^{\circ} \mathrm{C}$ e $5 \%$ de $\mathrm{CO}_{2}$, o preparo das placas é descrito abaixo. Com este plaqueamento a maioria dos contaminantes, tais como macrófagos e demais células possuidoras de receptores do tipo Fc, se ligam a IgG e podem ser removidas. Após este período de incubação as células que não se aderiram foram removidas através de batidas suavez no fundo da placa, aspiradas, quantificadas em câmara de Malassez e recentrifugadas como descrito acima. $O$ pellet resultante foi ressuspendido em DMEM contendo soro fetal bovino $10 \%$, Lglutamina $36,6 \mathrm{mg} / \mathrm{ml}, 100 \mu \mathrm{g} / \mathrm{ml}$ de esterptomicina, $100 \mathrm{U} / \mathrm{ml}$ de penicilina e 10 ng/ml de keratinocyte growth factor (KGF). Esta suspensão foi pré-plaqueada (préplating) por um período nunca inferior a 4 horas para a eliminação de eventuais fibroblastos. Com isto, nós nos aproveitamos da maior velocidade de adesão dos fibroblastos (cerca de uma hora) para a separação dos APTII (superior a 4 horas). Com o mesmo procedimento de batidas suaves no fundo das placas, os APTII foram recuperados e plaqueados em Matrigel/colágeno (70:30 vol/vol) e mantidos em incubadora a $37^{\circ} \mathrm{C}$ contendo $5 \%$ de $\mathrm{CO}_{2}$. O meio de cultura foi trocado após 24 horas e posteriormente a cada 48 horas. 


\subsubsection{Preparação da placa com lgG $500 \mu \mathrm{g} / \mathrm{ml}$}

Placas para o cultivo de bactérias (não irradiadas) foram cobertas com $100 \mu \mathrm{l}$ de IgG diluídas em PBS, pH 7,3, contendo BSA 0,1\%. A solução contendo lgG foi mantida em contato com a placa durante 3 horas a temperatura ambiente no interior da câmara de fluxo laminar. Após este período, a solução de lgG foi retirada e a placa lavada 5 vezes com PBS $(5 \times 1 \mathrm{ml})$ e uma vez com DMEM (1 ml). A solução de IgG foi reutilizada por pelo menos três vezes. Em nenhum momento permitiu-se que as placas viessem a secar. Todas as placas foram preparadas imediatamente antes do uso.

\subsubsection{Preparação do colágeno a ser adicionado ao matrigel}

A solução de colágeno (tipo IV) foi preparada de acordo com as instruções publicadas por Michalopoulos e Pitot (1975). Conforme descrito, aproximadamente 1

g de fibras de colágeno dissecado da cauda de dois ratos machos wistar, foram depositadas em uma placa de Petri e irradiada com luz ultravioleta por 24 horas a fim de se obter a completa esterilização. Estas fibras foram solubilizadas em $300 \mathrm{ml}$ de uma solução de ácido acético 1:1000 esterilizada. Esta solução foi mantida em agitação por um período de 48 horas a $4^{\circ} \mathrm{C}$. Após este período a solução foi deixada em repouso por 24 horas para permitir com que as fibras que não foram dissolvidas decantassem. Cuidadosamente, o sobrenadante foi recuperado. Para a neutralização do acido acético utilizado, $10 \mathrm{ml}$ da solução de colágeno foi acrescida de $10 \%$ de DMEM e o pH ajustado para uma condição superior a 7,0 com NaOH 3\%. Quando o DMEM atingia pH igual à 7, a coloração rósea se tornava translúcida. 


\subsubsection{Descrição e preparação do Matrigel}

O Matrigel (BD Biosciences) ou ECM gel (Sigma) foram utilizados. As principais classes de moléculas que regulam o desenvolvimento e a função celular são fatores de crescimento e de diferenciação, moléculas de adesão e componentes da matriz extracelular (ECM). Tanto o Matrigel quanto o ECM gel são definidos como moléculas secretadas que são imobilizadas no exterior da célula. Entretanto, ela não é morfologicamente visível. Entre os principais constituintes da matriz extracelular está o colágeno, as glicoproteínas não colagenosas e as proteoglicanas. A matriz extarcelular utilizada em nossos experimentos é proveniente do sarcoma de Engelbreth Holm-Swarm originário de camundongos. A concentração varia de 8-12 $\mathrm{mg} / \mathrm{ml}$ (Sigma) a $13 \mathrm{mg} / \mathrm{ml}$ (BD Biosciences). Ambos contém laminina como principal componente, além de colágeno tipo IV, heparan sulfate proteoglican, entactina e outros componentes de menor importância. A adição de colágeno tipo IV aumenta sua polimerização.

O Matrigel é comercializado e entregue congelado a $-20^{\circ} \mathrm{C}$ em frascos de 5 ml. O conteúdo foi descongelado por 24 horas a $4^{\circ} \mathrm{C}$ e diluído em PBS gelado no interior do próprio frasco. A diluição efetuada foi de 1/30 e alíquotas de $15 \mathrm{ml}$ foram conservadas na temperatura de $-20^{\circ} \mathrm{C}$. Para cada placa de cultura de $35 \mathrm{~mm}$, cerca de $250 \mu \mathrm{l}$ de Matrigel:colágeno (70:30 vol:vol) foi adicionado. A placa foi incubada a $37^{\circ} \mathrm{C}$ por 30 minutos em incubador de $\mathrm{CO}_{2}$. Após este período o sobrenadante foi aspirado e a placa deixada secar aberta, no interior do fluxo laminar por 15 minutos. Todas as placas foram preparadas imediatamente antes do uso. 


\subsubsection{Identificação dos APTII isolados}

4.2.3.1 Avaliação ultraestrutural através de microscopia eletrônica

A microscopia eletrônica foi realizada como previamente descrito (HASEGAWA et al., 2001). Para a observação em contraste de fase as células foram crescidas em lâminas de vidro de 35 mm cobertas com matrigel/colágeno (70:30 vol/vol). Para a observação dos corpos lamelares através de microscopia de transmissão, as células foram crescidas em membranas Millicell-PC de 0,4 $\mu \mathrm{m}$ (Millipore) nas mesmas condições acima descritas. As células foram mantidas em condições padrões de cultivo durante 48 horas. Após este período o meio de cultura foi aspirado e as células aderidas lavadas com PBS por duas vezes. As células foram fixadas com glutaroldeído 2,5\% em PBS por 4 minutos, seguida de fixação secundária em tetróxido de ósmio $1 \%$ por 10 minutos e desidratadas em gradiente de etanol por 15 minutos. Após este período as células foram submetidas ao ponto crítico de $\mathrm{CO}_{2}$ e então, embebidas em Epon overnight. As sessões de interesse foram cortadas em fragmentos com espessura de $4 \mu \mathrm{m}$. Para a microscopia de contraste de fase as células foram bombardeadas com partículas de ouro e fotografadas em seguida. Para a microscopia de transmissão eletrônica, sessões ultrafinas foram contrastadas com acetato de uranila por 10 minutos, deixado secar e examinadas em seguida. 


\subsubsection{Tetróxido de ósmio/ácido tânico}

A identificação dos APTII por meio da presença de corpos lamelares foi realizada diretamente sobre a placa de cultura de acordo com as especificações descritas por Manson et al. (1985). A monocamada foi lavada com três vezes com PBS, pH 7,3 e fixada com $500 \mu$ glutaroldeido 1,5\% durante 15 minutos. Após a fixação a monocamada foi lavada duas vezes com PBS, pH 7,3 e fixada com tetróxido de ósmio 1\% diluído em PBS por 1 hora em câmara escura. Novamente a monocamada foi lavada com PBS, duas vezes, e então, tratado overnight com ácido tânico 1\% diluído em PBS, pH 6,8. No dia seguinte, a monocamada foi lavada duas vezes com PBS e duas vezes com água MilliQ. Para a melhor visualização dos corpos lamelares, foi realizada uma coloração chamada de coloração policrômica. Esta coloração consiste na utilização de um corante Azul pré-diluída a $50 \%$ (solução estoque: Azul de metileno 130 mg; Azure II 20 mg; glicerol 10\%; metanol 10\% em água milliQ), seguida de coloração em corante Vermelho pré-diluída a $25 \%$ (solução estoque: Fucsina básica 200mg). O corante Azul foi aplicado durante 10 segundos e a monocamada lavada com $\mathrm{NaOH} 1 \%$ por 30 segundos. $\mathrm{O} \mathrm{NaOH} 1 \%$ foi retirado e o corante Vermelho foi aplicado por 2 segundos. A monocamada foi lavada três vezes com uma solução álcool-ácido ( $\mathrm{HCl} 1 \%$ em etanol $70 \%$ vol/vol). O corante vermelho foi reaplicado por 2 segundos, a monocamada lavada com água milliQ e a resultante estocada em uma solução de azida de sódio $0,1 \%$ diluída em água até análise. Para a identificação e quantificação das células, cerca de 500 células foram contadas por campo e o resultado expresso em porcentagem. Somente as células que se apresentavam aderidas e achatadas foram consideradas. A placa foi fotografada em seguida. 
4.2.3.3 Caracterização do citoesqueleto de actina dos APTII isolados

Nós utilizamos a faloidina acoplada ao TRITC para esta análise. Esta toxina possui a propriedade de se fixar aos filamentos de actina e de estabilizá-los, permitindo uma marcação direta do citoesqueleto de actina. Esta metodologia foi utilizada para averiguar a possibilidade dos APTII se aderirem ao plástico ou ao vidro sem a adição de colágeno mais matrigel.

A imunodetecção foi realizada sobre lâminas de vidro, cobertas ou não com Matrigel:colágeno (70:30 vol/vol). As lâminas foram tratadas com laminina $20 \mu \mathrm{g} / \mathrm{ml}$ diluída em PBS. Após três lavagens com PBS, as células foram fixadas em uma solução de para-formoldeído 0,5\% (vol/vol) diluído em PBS durante 12 minutos. Em seguida, as lâminas foram incubadas em uma solução de saturação durante 1 hora (PBS, BSA 0,1\%, Triton X-100 0,1\%). A faloidina foi empregada diretamente sobre as lâminas por uma hora. Com a finalidade de impedir o esgotamento da fluorescência, as lâminas foram em seguida montadas utilizando o vectashield (Vector Laboratoires) como meio de montagem, e conservadas ao abrigo da luz à $+4^{\circ} \mathrm{C}$ até a aquisição das imagens.

\subsubsection{Imunofluorescência}

\subsubsection{Preparação das laminas cobertas com gelatina}

As lâminas foram deixadas em contato com uma solução contendo HCl/Álcool (1:9 vol/vol) durante 1 hora. Em seguida, as lâminas permaneceram em banho contendo água MilliQ a $50^{\circ} \mathrm{C}$ por 5 minutos e secas em estufa ao abrigo de poeira. 
Estas lâminas foram cobertas com uma fina camada de gelatina $0,5 \%$ contendo Alun cromo $0,05 \%$ overnight à $37^{\circ} \mathrm{C}$ e conservadas à $4^{\circ} \mathrm{C}$ até o uso.

\subsubsection{Preparo dos tecidos para imunoistoquimica}

Os camundongos foram sacrificados, os pulmões instilados com o fixador Methacarn e deixados em contato overnight. No dia seguinte o fixador foi substituído por álcool $95^{\circ} \mathrm{GL}$ por 3 dias. Os pulmões foram reidratados durante 15 minutos em PBS, congelados em nitrogênio líquido e embebidos em Tissue-Tek ${ }^{\circledR}$. As amostras foram então, seccionadas em micrótomo, em seções de $4 \mu \mathrm{m}$ de espessura, montados em lâminas contendo gelatina e secas ao ar longe de partículas. As sessões foram incubadas em paraformoldeido $4 \%$ em tampão fosfato $0,1 \mathrm{M}, \mathrm{pH} 7,4-$ 7,5, durante 10 minutos. As lâminas foram lavadas em PBS, bloqueadas em BSA $3 \%$ contendo Triton $\mathrm{X}-100$ em PBS por 30 minutos a temperatura ambiente (CRONIER et al., 2002). Os anticorpos contra as conexinas 26, 32, 43 (Zymed, poli e monoclonal) foram utilizados na diluição de 1:100. Para a connexina 46 foram utilizados anticorpos policlonais, obtidos junto ao Dr. Michael Koval, diluídos na concentração de 1:500. Para a identificação dos APTII nós utilizamos o anticorpo monoclonal anti-mouse antipancitoqueratina FITIC conjugado clone C-11 (Sigma), que reconhece especificamente as citoqueratinas 8 e 18, fortemente expressas pelos APTII. As lâminas foram cuidadosamente mergulhadas em PBS por cinco vezes, e acrescidas dos anticorpos secundários FITC mouse ou TRITC mouse na diluição 1:100 durante 1 hora a temperatura ambiente. Ao final as lâminas foram montadas com Vectashield Mounting Médium (Vector Laboratories). 
4.2.4.3 Imunoflorescência dos APTII em cultura primaria

As células foram cultivadas em câmaras de 8 wells Permanox Slide (Lab-Tek Brand Products) confeccionados em plástico. Nós utilizamos o plástico pelo fato do Matrigel melhor se aderir. A imnunofluorescência foi realizada com as células no quarto dia de incubação. A metodologia utilizada foi a anteriormente descrita por Abraham et al. (1999). Detalhadamente, o meio de cultivo foi removido e a monocamada lavada 3 vezes com PBS, $\mathrm{pH} 7,3$ a $37^{\circ} \mathrm{C}$. As células foram permeabilizadas durante 2 minutos com metanol:acetona 1:1 a temperatura ambiente. Em seguida, foi efetuada a lavagem da monocamada três vezes com PBS a temperatura ambiente e a lâmina mergulhada cuidadosamente 5 vezes em PBS acrescido de triton $\mathrm{X}-100$ 0,5\%. O bloqueio foi realizado em PBS mais Triton $\mathrm{X}-100$ 0,5\% acrescido de heat-inactivated goat serum $2 \%$ durante 45 minutos. Esta solução foi utilizada varias vezes após filtração em membranas de 0,2 $\mu \mathrm{m}$ (Millipore).

As condições de aplicação dos anticorpos são as mesmas já mencionadas. Para a Cx26, 32 e 43 nós utilizamos anticorpos monoclonais diluídos 1:100 (Zymed). Para a Cx46 (1:500) foi utilizado anticorpo policlonal cedido pelo Dr. Michael Koval.

\subsubsection{Aquisição de Imagens}

As amostras imonomarcadas foram examinadas utilizando o microscópio confocal a laser Biorad MRC 1024 equipado com um laser 15mW. A unidade confocal foi ligada há um microscópio invertido (Olympus IX70). A máxima resolução foi obtida na objetiva de x60 utilizando-se água com 1.2 de abertura numérica. Seccionamento óptico das amostras (Z serie) foi efetuada com o auxílio de um motor 
que alternava campos em $0.5 \mu \mathrm{m}$ de distância e a máxima intensidade de projeção da imagem foi gerada. A aquisição do sinal fluorescente, e a construção da imagem foram realizadas através de um software controle (Lasersharp 3.2; Bio-Rad).

Triplas imagens fluorescentes foram geradas seqüencialmente. O FITC fluorocrome foi excitado com $488 \mathrm{~nm}$ blue line e a emissão da cor coletada via um fotomultiplicador através de um filtro de $522 \mathrm{~nm}$ pass band. O CY3 fluorocrome foi excitado com $568 \mathrm{~nm}$ yellow line e a emissão da cor coletada via fotomultiplicadora através de um filtro a $605 \mathrm{~nm}$ pass band. O ToPro3 fluorocromo (utilizado para corar os núcleos das células) foi excitado com 647 nm yellow line e a emissão da cor coletada via fotomultiplicadora através de um filtro a $680 \mathrm{~nm}$ pass band.

Para comparação dos diferentes níveis de expressão, todas as imagens foram coletadas utilizando o mesmo valor de potência do laser, ganho do fotomultiplicador, íris e nível de escuro.

\subsubsection{Western blot}

\subsubsection{Preparação das amostras}

Para este estudo, nós utilizamos quatro diferentes tipos celulares; APTII isolados, aqui chamado de APTII de dia zero; APTII mantida em cultura primaria até quarto dia; células da linhagem HeLa selvagem, as quais são deficientes em conexinas; e células HeLa trasnfectadas com as diferentes conexinas aqui estudadas, i.e., Cxs 26, 32, 43 e 46.

Para o estudo da expressão das conexinas em APTII no dia zero (0), as condições utilizadas são as mesmas já descritas. Após a extração o pellet foi 
ressuspendido em $200 \mu$ da solução SB20 (Dupont et al., 1989) (SDS 20\%; Tris 0,1M, pH 6,8; EDTA $10 \mathrm{mM}$ ). Para as células em cultura, a monocamada foi lavada com PBS e lisada rapidamente com $200 \mu \mathrm{l}$ da solução SB20. A utilização de um cell scrapper permitiu aumentar o rendimento da extração celular. Os lisados celulares são tratados por um sonicador 3 vezes na potencia máxima durante 5 segundos e armazenados $\mathrm{a}-80^{\circ} \mathrm{C}$ até análise.

\subsubsection{Quantificação de proteínas}

As proteínas foram quantificadas através do método de Lowry (LOWRY et al., 1951).

4.2.5.3 Eletroforese em gel de poliacrilamida sob condições denaturantes

As frações protéicas foram separadas por eletroforese em um gel de poliacrilamida na presença de SDS, com o auxílio de mini cubas verticais (SE 260, APB Pharmacia). Os lisados celulares foram solubilizados em um tampão de amostras (SB20/ $\beta$-mercaptoetanol 2,5\%; azul de bromofenol 2,5\%), de maneira a depositar a quantidade desejada de proteínas $(15 \mu \mathrm{g})$ em um volume final de $50 \mu \mathrm{l}$ por well.

A migração foi iniciada em um gel de aproximadamente $1,5 \mathrm{~cm}$ de altura (TrisBase 125 mM, pH 6,8; SDS 0,1\%; acrilamida 4,5\%), sob potencial Constant de $60 \mathrm{~V}$. A eletroforese prosseguiu em um gel de separação (Tris-Base 375 mM, pH 8,8; SDS 0,1\%; acrilamida 12,5\%), sob voltagem de $120 \mathrm{~V}$. A eletroforese foi conduzida 
em Tampão de Migração (Tris-Base 25 mM; SDS 0,1\%; glicina 192 mM; pH 8,2 a $8,5)$.

\subsubsection{Eletro-transferência das proteínas}

A eletroforese foi interrompida quando a fronte de migração, visualizada graças ao azul de bromofenol, atingiu a porção inferior do gel e começou a sair para o meio. As proteínas do gel podem ser coloridas com azul de bromofenol ou transferidas para uma membrana de nitrocelulose (Biorad). Para isso, o gel foi colocado em um tampão de transferência (Tris-Base 25 mM; glicina 192 mM, SDS 0,01\%; metanol $10 \%$; $\mathrm{pH} 8,2$ a 8,5), assim como a membrana e os blotting paper. Um "sanduíche" foi produzido da seguinte maneira: uma folha de boltting paper, o gel de poliacrilamida, a membrana de nitrocelulose, uma outra folha de blotting paper. A transferência se efetuou a $150 \mathrm{~mA}$ durante 2 horas a $4^{\circ} \mathrm{C}$.

\subsubsection{Imunodetecção das proteínas de interesse}

Após três lavagens em TTBS (Tris-Base 20 mM, pH 7,6, NaCl 150 mM, Tween 20 a 0,1\%), com duração de 5 minutos cada, a membrana foi incubada durante uma hora em solução de saturação de TTBS acrescida de leite desnatado $5 \%$ (p/vol). Após esta etapa, a membrana foi lavada três vezes com TTBS durante cinco minutos cada. A membrana foi incubada com anticorpos primários policlonal para as conexinas 26 (1:1000, Zymed), 43 (1:1000, Zymed) e 46 (1:2000, Dr. Koval), e monoclonal para a connexina 32 (1:2000, Zymed), diluídos em PBS overnight sob agitação constante a $4^{\circ} \mathrm{C}$. No dia seguinte, a membrana foi lavada com TTBS nas 
mesmas condições acima citadas e os anticorpos secundários antimouse ou antirabbit (Zymed) diluídos na proporção 1:2000 foram aplicados durante 1 hora à temperatura ambiente. Os anticorpos secundários foram removidos e a membrana lavada três vezes com TTBS durante 30 minutos, sendo a mesma traçada a cada 15 minutos. A membrana foi em seguida incubada ao abrigo da luz em uma solução de NBT (4-Nitro Blue Tetrazolium, 0,33\% (p/vol))e de BCIP (5-Bromo 4-Cloro Indoyl fosfato de toluidina, $0,16 \%(\mathrm{p} / \mathrm{vol}))$ em água MilliQ.

A defosforilação do BCIP pela fosfatase alcalina em presença de N,N demetilformamida, gera um complexo colorido na presença do azul de tetrazolium. Quando a intensidade de coloração parece suficiente, a reação foi interrompida lavando a membrana em água destilada.

\subsubsection{Western blot das conexinas provenientes dos tecidos}

Para a estimação da Cx43 nos órgãos de camundongos $C \times 43^{+/-}$e $\quad$ Cx43 (principalmente pulmões e coração), nós utilizamos camundongos fêmeas, $\mathrm{C} \times 43^{+/-} \mathrm{e}$ $\mathrm{C} \times 43^{+/+}$. Fragmentos dos órgãos $(40 \mathrm{mg})$ foram homogeneizados num tampão contendo $60 \mathrm{mM}$ Tris- $\mathrm{HCl}, \mathrm{pH} 6.8$, SDS a $2 \%$, glicerol a $12 \%$, ditiotreitol $0,1 \mathrm{M}$ e fluoreto de sulfato de sódio (SDS), e mantidas em gelo. As amostras foram centrifugadas por 15 minutos a 13000 rpm e o sobrenadante recuperado. O pellet foi desprezado, as proteínas quantificadas pelo método de Bradford e as amostras aliquotadas em seguida. As amostras foram mantidas a $-80^{\circ} \mathrm{C}$ até análise. $\mathrm{O}$ western blot foi realizado como descrito acima. 


\subsubsection{Caracterização da cultura de APTII}

4.2.6.1 Avaliação da capacidade de comunicação dos APTII através da técnica de Scrape-loading

A GJIC foi acessada utilizando a técnica de scrape-loading descrita por ElFouly (1987). Para este estudo nós utilizamos a cultura de células de APTII confluentes em placas de $35 \mathrm{~mm}$ de diâmetro. Foram adicionadas no dia zero de cultura $1 \times 10^{7}$ cells $/ \mathrm{ml}$. Estas células foram cultivadas até o quarto dia quando o meio de cultura foi aspirado, e a monocamada lavada três vezes com PBS a $37^{\circ} \mathrm{C}$. De 3 a 5 traços foram produzidos, cuidadosamente com o auxílio de uma régua e um bisturi. Rapidamente, $500 \mu \mathrm{l}$ de uma solução contendo amarelo de Lúcifer $5 \%$ (457 Da) acrescido de albumina rodamina 0,25\% (10000 Da). Esta combinação foi deixada em contato por 5 minutos ao abrigo da luz na temperatura ambiente. Após este período de tempo, a solução foi removida e a monocamada lavada três vezes com PBS. Imediatamente, $1 \mathrm{ml}$ de paraformoldeido 4\% diluído em PBS, pH 7,0, foi adicionado e as placas armazenadas a $4^{\circ} \mathrm{C}$ ao abrigo da luz até que as fotos fossem adquiridas. À distância que o amarelo de Lúcifer viajou foi avaliada em um microscópio de fluorescência invertido acoplado a um computador. 


\subsubsection{Capacidade de proliferação dos APTII}

Para avaliar a capacidade de proliferação dos APTII em cultura primária nós utilizamos o teste do MTT descrita por Hasegawa et al. (2001). O teste do MTT é uma medida da atividade da succinato desidrogenase mitocondrial de células vivas. Esta enzima, cliva o tetrazólio cíclico, tornando o MTT (brometo de 3 (4,5dimetiltiazol-2-yl) 2,5-difeniltetrazolio), de cor amarela, em cristais azuis de formazan. Após a dissolução destes cristais em uma solução ácida, a leitura escpectrofotométrica a $570 \mathrm{~nm}$ pode ser realizada. A proliferação celular é baseada na quantidade de MTT convertidos em cristais de formazan pelo succinato desidrogenase, i.e., quanto maior a absorbância maior número de células em proliferação.

As células foram plaqueadas na concentração de $6 \times 10^{6}$ células $/ \mathrm{ml}$ e a proliferação avaliada nos dias 4, 6 e 8 de cultura, em triplicata. O MTT (Sigma - M5655) foi dissolvido em PBS, pH 7,3, na concentração de 2,5 mg/ml. Esta solução foi filtrada em membrana com poros de $0,2 \mu \mathrm{m}$, e diluída na concentração de $10 \%$ em DMEM contendo KGF. O meio de cultura da placa foi substituído pelo meio de cultura contendo MTT e incubada em estufa de $\mathrm{CO}_{2}$ por um período de 3 horas. Após este período de tempo, o meio foi aspirado e substituído por $1 \mathrm{ml}$ da solução de ácido isopropílico. Neste momento é possível verificar a coloração azul das células em cultura. A solução de álcool isopropílico foi preparada adicionando-se 40 $\mu \mathrm{l}$ de ácido clorídrico $35 \%$ em $9,96 \mathrm{ml}$ de álcool isopropílico. As placas foram mantidas fechadas à temperatura ambiente, os cristais solubilizados com o auxílio de uma pipeta Pasteur e a D.O. registrada a 570 nm. O espectrofotômetro foi zerado 
empregando-se a própria amostra a $630 \mathrm{~nm}$, lembrando que o formazan não absorve luz entre 620 a $650 \mathrm{~nm}$. 


\section{RESULTADOS}

\subsection{Resultados obtidos na FMVZ/USP}

\subsubsection{Genotipagem}

padrão de identificação dos camundongos é apresentado na figura 18. Os camundongos $\mathrm{C} \times 43^{+/+}$apresentam uma única banda de identificação que pode ser observada na altura de 520 pb. A presença única do gene neo, identificado em 294 pb, permite a identificação do camundongo Cx43-/- (não utilizado nesta tese). Já a presença do gene neo e do gene da Cx43 faz referência ao camundongo $\mathrm{C} \times 43^{+/-}$

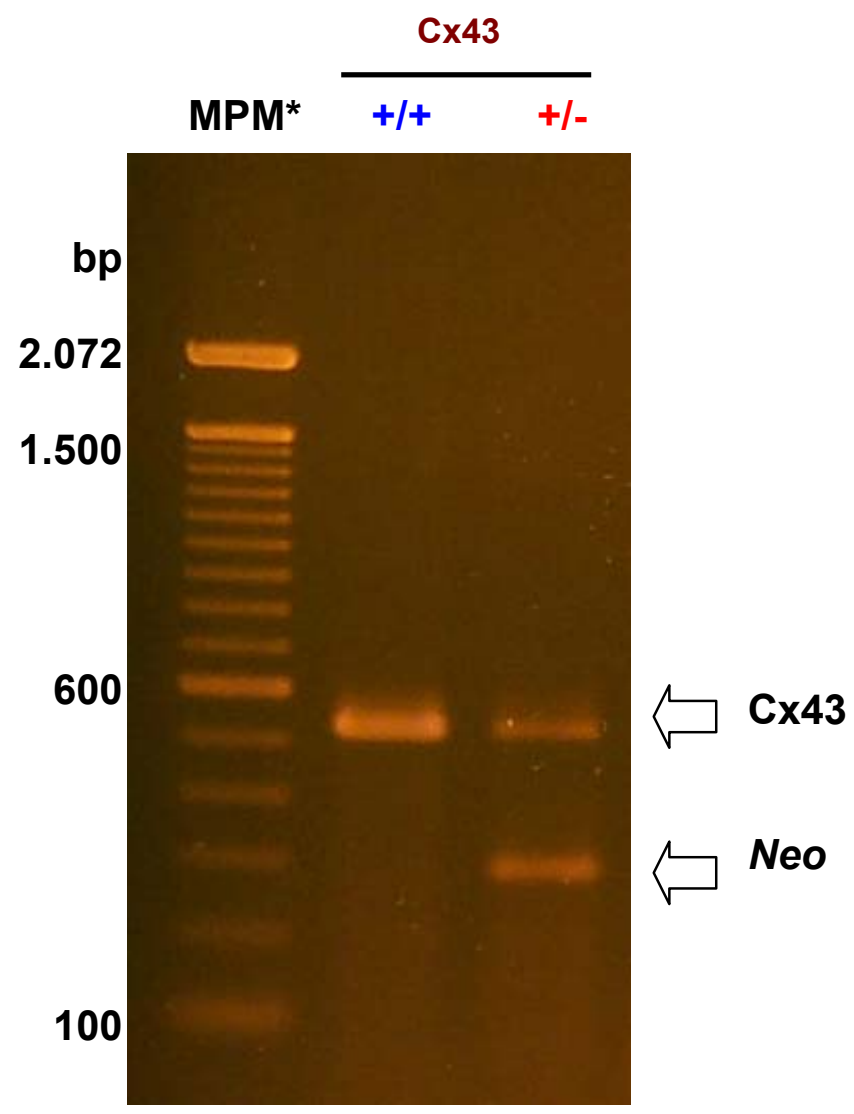

Figura 18 - Fotografia do gel de agarose apresentando os spots correspondentes aos amplicons que identificam os camundongos $\mathrm{C} \times 43^{+/-}$e $\mathrm{C} \times 43^{+/+}$produzida através da técnica de PCR. O DNA da cauda dos camundongos foi amplificado utilizando os primers da neomicina e da Cx43 como descrito no "Material e Métodos". *O marcador de peso molecular (MPM) foi preparado e utilizado de acordo com as instruções fornecidas pela Gibco ${ }^{\circledR}$. O amplicom resultante para a Cx43 é observado na latura de $520 \mathrm{pb}$, enquanto que o amplicom do gene neo é observado na altura de 294 pb. pb: pares de base; +/+: camundongo selvagem; +/-: camundongo heterozigoto 
Após a identificação pelo método de PCR os camundongos foram separados nos grupos experimentais ou utilizados para a manutenção da colônia de camundongos no biotério.

\subsubsection{Carcinogênese pulmonar}

5.1.2.1 Características genotípicas da prole de camundongos $\mathrm{C} \times 43^{+/-}$utilizados no experimento de carcinogênese

Os dados das porcentagens e dos números absolutos de camundongos $\mathrm{Cx}_{43^{+/-}}$e $\mathrm{C} \times 43^{+/+}$obtidos após cruzamento podem ser observados no tabela 13.

Tabela 13 - Porcentagem de camundongos Cx43 ${ }^{+/-}$e $\mathrm{Cx} 43^{+/+}$utilizados no experimento de carcinogênese pulmonar

\begin{tabular}{|c|c|c|c|}
\hline Sexo & Genótipo & $\%$ & Total \\
\hline \multirow{2}{*}{ Fêmeas } & $\mathrm{C} \times 43^{+/+}(\mathrm{n}=57)$ & 30.00 & \multirow{4}{*}{190} \\
\hline & $C \times 43^{+/-}(n=40)$ & 21.05 & \\
\hline \multirow{2}{*}{ Machos } & $\mathrm{C} \times 43^{+/+}(\mathrm{n}=51)$ & 26.84 & \\
\hline & $\mathrm{C} \times 43^{+/-}(\mathrm{n}=42)$ & 22.10 & \\
\hline
\end{tabular}

$\mathrm{n}=$ número de camundongos por grupo.

A quantidade de camundongos $\mathrm{Cx} 43^{+/-}$obtidos foi de $43,15 \%$ (Tabela 13 ), uma quantidade $6,75 \%$ abaixo do esperado, ou seja, os $50 \%$ estabelecidos pela $2^{\circ}$ Lei da genética de Mendel quando cruzados camundongos $\mathrm{C} \times 43^{+/+}$(homozigotos) com os camundongos $\mathrm{Cx} 43^{+/-}$. No entanto, após outros cruzamentos no biotério da FMVZ, com n superior, verificou-se que a proporção de $50 \%$ é estabelecida. Durante o transcorrer do experimento observou-se entre os camundongos $\mathrm{Cx} 43^{+/+}$uma taxa de mortalidade de $8 \%$. Já, entre os camundongos $\mathrm{C} \times 43^{+/-}$a taxa mortalidade observada 
foi de $1,05 \%$. Todas as mortes foram observadas na fase final do exprimento na transição das semanas 23 para 24 do período experimental.

5.1.2.2 - Evolução do peso corpóreo dos camundongos $\mathrm{C} \times 43^{+/-}$e $\mathrm{C} \times 43^{+/+}$durante o experimento de carcinogênese pulmonar

Após a aplicação da uretana, aos 15 dias de idade, observou-se que os camundongos deixaram de ganhar peso até a $3^{\circ}$ semana de idade $(P<0,01)$. $O$ relatado pode ser observado na figura 19. O peso dos camundongos nesta semana apresentou-se inferior ao peso dos camundongos comumente desmamados aos 21 dias no biotério de Experimentação Animal da FMVZ. Assim, somente com 28 dias de idade os camundongos foram desmamados, identificados e o fragmento da cauda, cerca de $1 \mathrm{~cm}$, foi coletado para a genotipagem acima descrito.

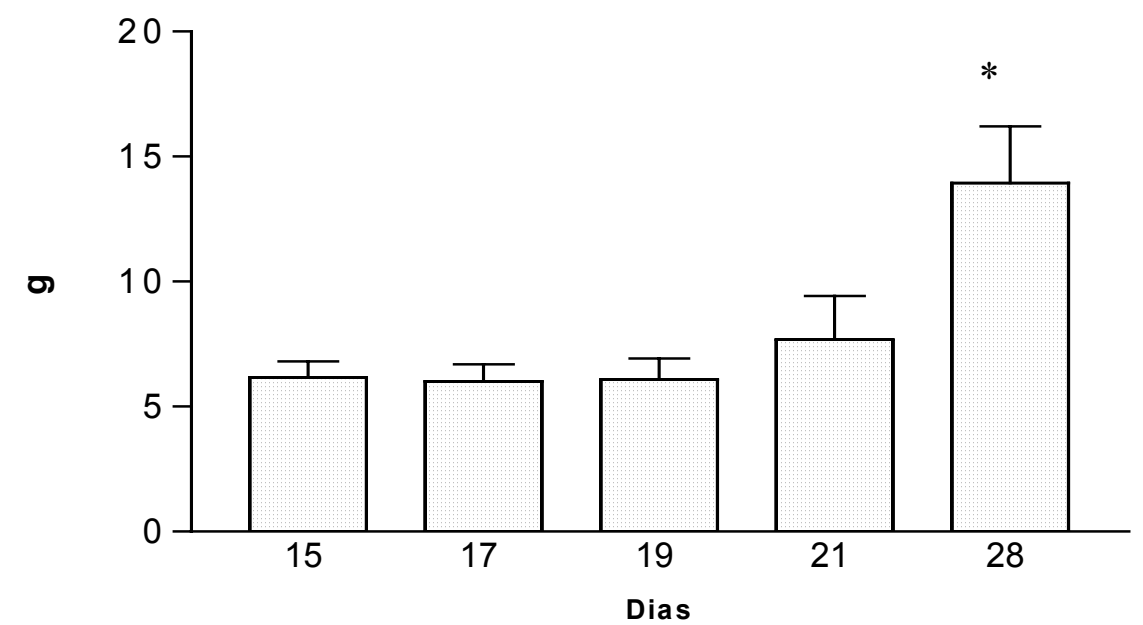

Figura 19 - Evolução dos pesos corpóreos médios dos camundongos após a injeção intraperitoneal de uretana $3 \mathrm{~g} / \mathrm{Kg}$, dividida em duas doses de $1,5 \mathrm{~g} / \mathrm{Kg}$ aos 15 e 17 dias de idade. Os camundongos, até o presente momento, não tinham sido genotipados. Pode-se observar que do momento da aplicação da uretana até 21 dias os camundongos não ganharam peso. A barra identificada com * é significativamente diferente pelo teste de Tukey $(\mathrm{P}<0,01)$. Os dados são médias e desvios padrão correspondentes a 96 camundongos submetidos ao tratamento com uretana 
A descrição das características dos grupos experimentais empregados no estudo de carcinogênese pulmonar está representada na tabela 14 e na figura 20.

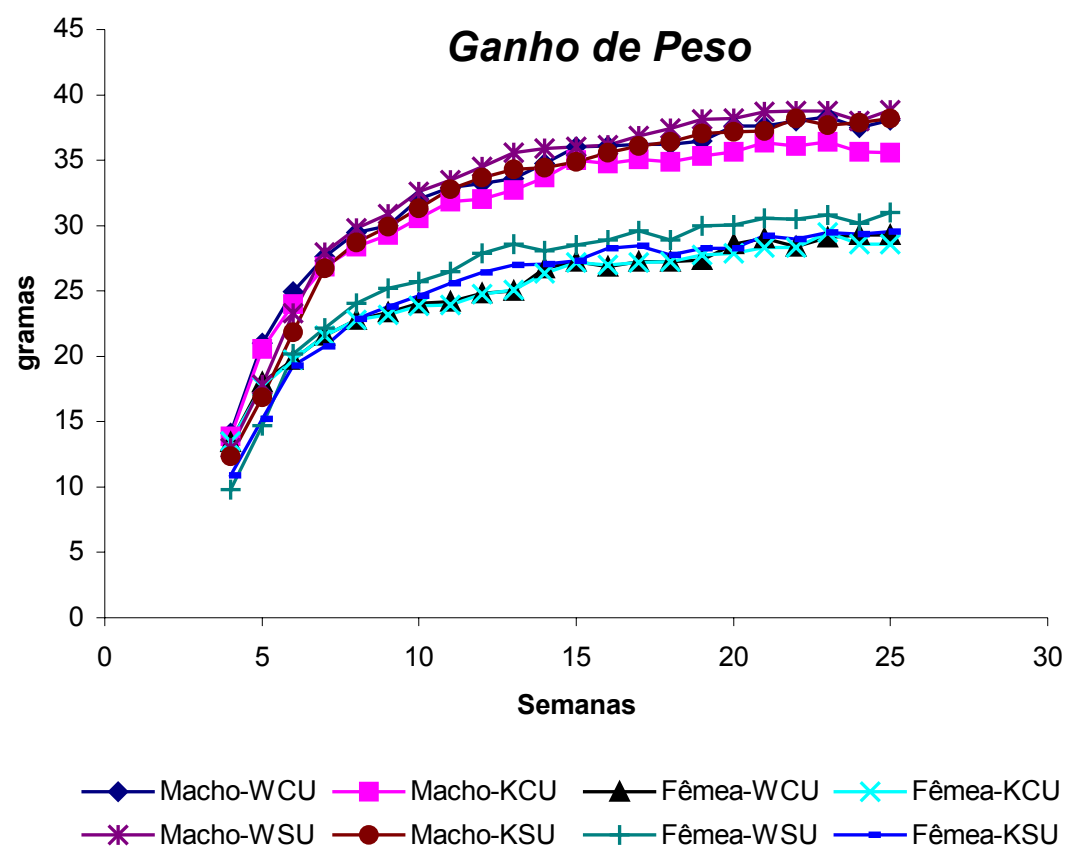

Figura 20 - Média do ganho de peso semanal dos camundongos $\mathrm{C} \times 43^{+/+}$e $\mathrm{C} \times 43^{+/-}$. Cada ponto representa a média do ganho de peso de 26 (Machos - WCU); 18 (Machos - HCU); 24 (Fêmeas - WCU) e 23 (Fêmeas - HCU). A única diferença observada diz respeito ao sexo. H - Heterozigoto; W - Selvagem; CU - desafiado com uretana aos 15 e 17 dias de idade, SU - não desafiado com uretana aos 15 e 17 dias de idade

Não se observou alteração significativa no peso dos camundongos do mesmo sexo iniciados ou não pela uretana $(P>0,01)$. As fêmeas apresentaram peso corpóreo menor que os machos (Tabela 14 e Figura 20). 
5.1.2.3 Incidência de lesões macroscópicas nos camundongos iniciados com a uretana

A avaliação macroscópica das neoplasias foi feita contando-se o número de nódulos em cada lobo pulmonar, i.e., nos Lobos Apical, Médio, Diafragmático, Esquerdo e Acessório com o tecido ainda fresco (Figura 21); o fixador foi injetado para inflar os pulmões e a contagem realizada imediatamente.

A incidência, o número e a distribuição dos nódulos pulmonares visíveis dos camundongos $\mathrm{Cx} 43^{+/+}$e $\mathrm{Cx} 43^{+/-}$submetidos à injeção intraperitoneal de uretana, podem ser observados na tabela 15 . Nos camundongos $\mathrm{C} \times 43^{+/-}$foi observada a maior incidência de lesões. Entre os camundongos machos o número de lesões foi superior. Pelo fato da área do lobo pulmonar esquerdo ser muito superior a dos demais lobos, o maior número de lesões aqui observadas são consideradas normais.

Assim, relataram-se sempre maiores números de nódulos relativos ao tamanho do lobo. Verificou-se que a totalidade dos camundongos $(100 \%$ dos camundongos) tinham lesões. Apenas um camundongo $\mathrm{C} \times 43^{+/-}$macho não apresentou lesões macroscópicas. As maiores lesões foram verificadas nos camundongos $\mathrm{C} \times 43^{+/-}$. O número médio de lesões observadas nos camundongos machos $\mathrm{Cx}_{43^{+/}}$foi de $19.74 \pm 7.68$. Este resultado foi estatísticamente significante $(\mathrm{P}<0,001)$ quando comparado aos camundongos machos e fêmeas selvagens. Em relação às fêmeas $C \times 43^{+/-}$, o resultado também foi significante $(P<0,05)$. Interessantemente, não se observou diferença estatística significativa no número médio de lesões por camundongo entre as fêmeas $(P>0,05)$, quando comparados os camundongos com diferentes genótipos. 

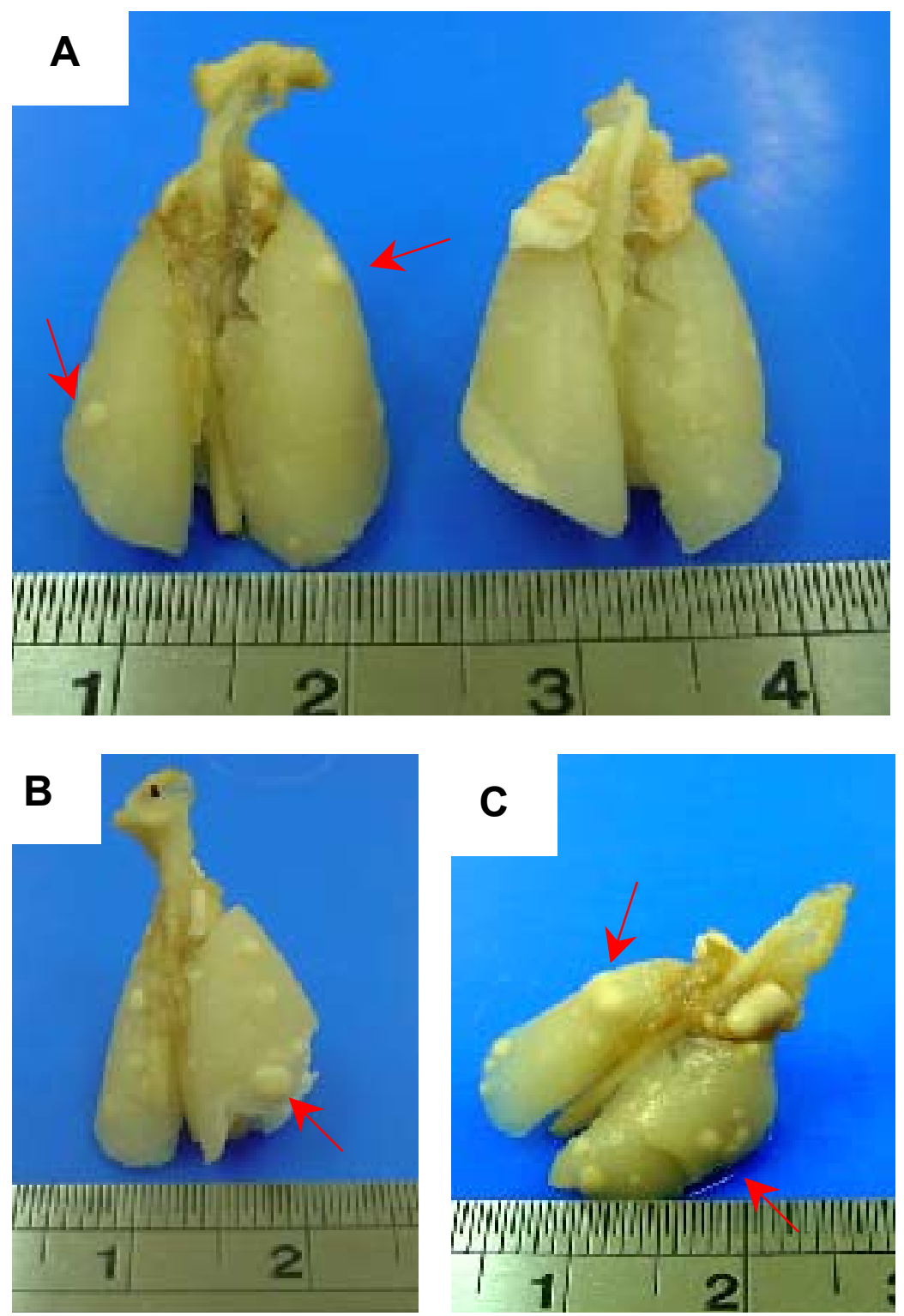

Figura 21 - Fotografia apresentando o pulmão dos camundongos iniciados com uretana e sacrificados com 25 semanas de idade. A. A direita pode ser observado o pulmão de um camundongo macho e a esquerda de um camundongo fêmea ambos $\mathrm{C} \times 43^{+/+}$. Nota-se a menor quantidade de lesões comparadas aos $\mathrm{C} \times 43^{+/-}$. B. Pulmão representando os camundongos fêmea $\mathrm{Cx} 43^{+/-}$. C. Pulmão de camundongo macho $\mathrm{C} \times 43^{+/-}$. As setas apontam para os adenomas. Note que nos camundongos $\mathrm{C} \times 43^{+/-}$as lesões além de mais numerosas, também são maiores. 
Tabela 14 - Ganho de peso semanal dos camundongos $\mathrm{C} \times 43^{+/+}$e $\mathrm{Cx} 43^{+/-}$desafiados ou não com uretana

\begin{tabular}{|c|c|c|c|c|c|c|c|c|c|c|c|}
\hline \multirow{2}{*}{ Grupos } & \multicolumn{11}{|c|}{ Semanas } \\
\hline & 4 & 5 & 6 & 7 & 8 & 9 & 10 & 11 & 12 & 13 & 14 \\
\hline $\mathrm{C} \times 43^{+/+}$ & $14.16 \pm 2.48^{\mathrm{A}}$ & $21.02 \pm 2.33^{A}$ & $24.95 \pm 1.68^{\mathrm{A}}$ & $27.63 \pm 1.71^{\mathrm{A}}$ & $29.48 \pm 1.63^{A}$ & $30.00 \pm 1.42^{\mathrm{A}}$ & $32.00 \pm 1.41^{\mathrm{A}}$ & $32.91 \pm 1.50^{A}$ & $33.21 \pm 1.68^{\mathrm{A}}$ & $33.63 \pm 1.63^{\mathrm{A}}$ & $34.78 \pm 1.47^{\mathrm{A}}$ \\
\hline $\mathrm{C} \times 43^{+/-}$ & $13.87 \pm 3.02^{\mathrm{A}}$ & $20.58 \pm 2.82^{\mathrm{A}}$ & $24.02 \pm 2.58^{\mathrm{A}}$ & $26.86 \pm 2.05^{\mathrm{A}}$ & $28.38 \pm 1.97^{\mathrm{B}}$ & $29.26 \pm 2.09^{A}$ & $30.57 \pm 2.07^{\mathrm{B}}$ & $31.84 \pm 2.27^{\mathrm{A}}$ & $32.02 \pm 2.35^{\mathrm{A}}$ & $32.70 \pm 2.27^{\mathrm{A}}$ & $33.65 \pm 3.19^{A}$ \\
\hline$+\mathrm{Cx} 43^{+/+}$ & $13.45 \pm 1.62^{\mathrm{A}}$ & $18.00 \pm 1.54^{\mathrm{B}}$ & $19.72 \pm 1.43^{\mathrm{B}}$ & $21.59 \pm 1.44^{B}$ & $22.78 \pm 1.31^{B}$ & $23.36 \pm 1.34^{\mathrm{B}}$ & $24.04 \pm 1.46^{\mathrm{B}}$ & $24.19 \pm 1.50^{B}$ & $24.85 \pm 1.45^{B}$ & $25.03 \pm 1.57^{B}$ & $26.71 \pm 3.04^{\mathrm{B}}$ \\
\hline$+\mathrm{Cx}_{4} 3^{+/-}$ & $13.47 \pm 1.64^{\mathrm{A}}$ & $17.72 \pm 1.43^{B}$ & $19.71 \pm 1.42^{B}$ & $21.58 \pm 1.16^{B}$ & $22.78 \pm 1.13^{B}$ & $23.14 \pm 1.14^{B}$ & $23.86 \pm 1.02^{B}$ & $23.95 \pm 1.31^{B}$ & $24.78 \pm 1.24^{B}$ & $25.07 \pm 1.03^{B}$ & $26.36 \pm 1.27^{\mathrm{B}}$ \\
\hline $\mathrm{C} \times 43^{+/+}$ & $13.00 \pm 3.35^{x}$ & $17.81 \pm 3.76^{x}$ & $23.27 \pm 4.37^{x}$ & $27.95 \pm 4.37^{x}$ & $29.77 \pm 3.50^{x}$ & $30.88 \pm 3.33^{x}$ & $32.59 \pm 3.22^{x}$ & $33.47 \pm 3.62^{x}$ & $34.51 \pm 2.73^{x}$ & $35.58 \pm 3.17^{x}$ & $35.90 \pm 3.02^{x}$ \\
\hline $\mathrm{C}^{2} \times 43^{+/-}$ & $12.32 \pm 4.52^{\mathrm{x}}$ & $16.85 \pm 4.50^{x}$ & $21.86 \pm 5.38^{x}$ & $26.73 \pm 2.64^{x}$ & $28.70 \pm 2.81^{x}$ & $29.89 \pm 3.25^{x}$ & $31.30 \pm 3.28^{x}$ & $32.76 \pm 3.49^{x}$ & $33.69 \pm 2.60^{x}$ & $34.30 \pm 3.05^{x}$ & $34.45 \pm 2.95^{x}$ \\
\hline$+\mathrm{Cx} 43^{+/+}$ & $10.89 \pm 2.20^{X Y}$ & $15.19 \pm 3.25^{x}$ & $19.26 \pm 3.09^{x}$ & $20.77 \pm 2.54^{\curlyvee}$ & $22.84 \pm 3.08^{Y}$ & $23.79 \pm 2.29^{Y}$ & $24.63 \pm 2.55^{\curlyvee}$ & $25.56 \pm 2.66^{Y}$ & $26.44 \pm 2.23^{Y}$ & $26.96 \pm 2.82^{Y}$ & $27.06 \pm 2.83^{\curlyvee}$ \\
\hline$+\mathrm{C} \times 43^{+/-}$ & $9.83 \pm 2.96^{Y}$ & $14.73 \pm 3.71^{x}$ & $20.19 \pm 2.53^{x}$ & $22.15 \pm 1.79^{Y}$ & $24.05 \pm 2.28^{Y}$ & $25.20 \pm 1.86^{Y}$ & $25.74 \pm 1.61^{\curlyvee}$ & $26.49 \pm 1.64^{\curlyvee}$ & $27.91 \pm 1.82^{Y}$ & $28.59 \pm 2.18^{Y}$ & $28.04 \pm 1.99^{Y}$ \\
\hline \multirow{2}{*}{ Grupos } & \multicolumn{11}{|c|}{ Semanas } \\
\hline & 15 & 16 & 17 & 18 & 19 & 20 & 21 & 22 & 23 & 24 & 25 \\
\hline${ }^{7} \mathrm{C} \times 43^{+/+}$ & $36.04 \pm 1.95^{\mathrm{A}}$ & $36.06 \pm 1.85^{\mathrm{A}}$ & $36.24 \pm 1.75^{\mathrm{A}}$ & $36.24 \pm 1.78^{A}$ & $36.47 \pm 2.56^{\mathrm{A}}$ & $37.60 \pm 2.16^{A}$ & $37.61 \pm 1.79^{A}$ & $38.01 \pm 2.10^{A}$ & $38.34 \pm 2.20^{A}$ & $37.51 \pm 2.19^{A}$ & $38.04 \pm 2.20^{A}$ \\
\hline $\mathrm{C} \times 43^{+/-}$ & $35.03 \pm 2.29^{A}$ & $34.76 \pm 2.38^{\mathrm{B}}$ & $35.08 \pm 2.27^{\mathrm{A}}$ & $34.87 \pm 2.25^{\mathrm{B}}$ & $35.32 \pm 2.28^{\mathrm{A}}$ & $35.63 \pm 2.20^{\mathrm{A}}$ & $36.37 \pm 2.02^{\mathrm{A}}$ & $36.07 \pm 2.46^{\mathrm{A}}$ & $36.43 \pm 2.40^{\mathrm{A}}$ & $35.62 \pm 2.59^{\mathrm{A}}$ & $35.61 \pm 2.47^{\mathrm{A}}$ \\
\hline$+\mathrm{Cx} 43^{+/+}$ & $27.25 \pm 1.74^{B}$ & $26.85 \pm 1.79^{B}$ & $27.24 \pm 1.67^{\mathrm{B}}$ & $27.27 \pm 2.20^{B}$ & $27.40 \pm 1.95^{\mathrm{B}}$ & $28.59 \pm 2.40^{B}$ & $29.04 \pm 2.42^{B}$ & $28.37 \pm 2.46^{\mathrm{B}}$ & $29.06 \pm 2.97^{\mathrm{B}}$ & $29.26 \pm 2.61^{\mathrm{B}}$ & $29.29 \pm 2.65^{\mathrm{B}}$ \\
\hline $9 \mathrm{C} \times 43^{+/-}$ & $27.20 \pm 1.18^{B}$ & $26.97 \pm 1.60^{B}$ & $27.18 \pm 1.56^{B}$ & $27.23 \pm 1.71^{\mathrm{B}}$ & $27.73 \pm 1.76^{\mathrm{B}}$ & $27.85 \pm 1.74^{B}$ & $28.33 \pm 1.71^{B}$ & $28.30 \pm 1.75^{B}$ & $29.50 \pm 2.72^{B}$ & $28.55 \pm 1.88^{\mathrm{B}}$ & $28.59 \pm 2.11^{\mathrm{B}}$ \\
\hline $\mathrm{C} \times 43^{+/+}$ & $36.05 \pm 2.93^{x}$ & $36.16 \pm 3.01^{x}$ & $36.88 \pm 3.08^{x}$ & $37.42 \pm 3.31^{x}$ & $38.11 \pm 3.20^{x}$ & $38.03 \pm 2.98^{x}$ & $38.16 \pm 2.79^{x}$ & $38.71 \pm 2.66^{\mathrm{x}}$ & $38.74 \pm 2.81^{x}$ & $38.79 \pm 2.93^{x}$ & $38.82 \pm 2.41^{x}$ \\
\hline $\mathrm{C}^{2} 43^{+/-}$ & $34.86 \pm 2.87^{x}$ & $35.58 \pm 2.33^{x}$ & $36.06 \pm 2.42^{x}$ & $36.38 \pm 2.32^{x}$ & $37.02 \pm 2.56^{x}$ & $37.16 \pm 2.56^{x}$ & $37.25 \pm 2.22^{x}$ & $38.18 \pm 2.26^{x}$ & $37.68 \pm 2.30^{x}$ & $37.88 \pm 2.35^{x}$ & $38.17 \pm 2.80^{x}$ \\
\hline$+\mathrm{Cx} 43^{+/+}$ & $27.33 \pm 2.73^{Y}$ & $28.24 \pm 3.61^{Y}$ & $28.47 \pm 3.49^{Y}$ & $27.75 \pm 2.86^{\curlyvee}$ & $28.23 \pm 2.58^{Y}$ & $28.26 \pm 3.09^{Y}$ & $29.21 \pm 2.89^{\curlyvee}$ & $28.97 \pm 2.42^{Y}$ & $29.47 \pm 2.35^{Y}$ & $29.37 \pm 2.32^{Y}$ & $29.55 \pm 2.58^{Y}$ \\
\hline$+\mathrm{C} \times 43^{+/-}$ & $28.52 \pm 1.72^{Y}$ & $28.87 \pm 1.88^{Y}$ & $29.57 \pm 2.47^{Y}$ & $28.90 \pm 2.30^{Y}$ & $29.95 \pm 1.94^{Y}$ & $30.07 \pm 2.06^{Y}$ & $30.53 \pm 2.13^{Y}$ & $30.46 \pm 1.94^{Y}$ & $30.82 \pm 1.94^{Y}$ & $30.14 \pm 1.12^{Y}$ & $30.97 \pm 2.21^{\curlyvee}$ \\
\hline
\end{tabular}

$\square$ tratados com uretana; $\square$ sem tratamento com uretana. Os camundongos foram sacrificados com 6 meses de idade com injeção intraperitoneal de Tiopental sódico $250 \mathrm{mg} / \mathrm{g}$ de peso vivo. Os resultados são Média \pm Desvio padrão de 26; 18; 23 e 24 camundongos, respectivamente. Médias seguidas de mesma letra na mesma coluna, não diferem significativamente entre si pelo teste de Tukey $(P>0,0001)$. 
Tabela 15 - Incidência, número e distribuição por tamanho dos nódulos pulmonares visíveis dos camundongos $\mathrm{Cx} 43^{+/+}$e $\mathrm{Cx} 43^{+/-}$submetidos à injeção intraperitoneal de uretana ou não

\begin{tabular}{|c|c|c|c|c|c|c|c|c|c|c|c|c|}
\hline \multirow[t]{2}{*}{ Grupos } & \multirow{2}{*}{$\begin{array}{c}\mathrm{n}^{\circ} \text { de cam. } \\
\text { vivos com } \\
\text { nódulos / total } \\
\text { de } \\
\text { camundongos }\end{array}$} & \multirow{2}{*}{$\begin{array}{c}\text { Média } \mathrm{n}^{\circ} \\
\text { nódulos/camund } \\
\text { ongo com nódulo } \\
\text { (multiplicidade) }\end{array}$} & \multirow{2}{*}{$\begin{array}{l}\text { Incidênci } \\
\text { a de } \\
\text { nódulos } \\
\text { (\%) }\end{array}$} & \multirow[b]{2}{*}{ Apical } & \multicolumn{4}{|c|}{ Total do $n^{\circ}$ de nódulos / lobo } & \multicolumn{3}{|c|}{$\begin{array}{l}\text { Nódulos relativo ao tamanho } \\
\text { ( } \% \text { do número total) }\end{array}$} & \multirow[t]{2}{*}{$\begin{array}{l}\text { Total de } \\
\text { nódulos }\end{array}$} \\
\hline & & & & & Médio & Diafg. & Esq. & Aces. & $\leq 1$ & $>1-<3$ & $\geq 3$ & \\
\hline $\mathrm{C} \times 43^{+/+}$ & $23 / 23$ & $9.88 \pm 5.43^{\mathrm{B}^{* *}}$ & 100 & 52 & 26 & 51 & 79 & 9 & 202 & 15 & 0 & 217 \\
\hline $\mathrm{J}^{7} \mathrm{C} \times 43^{+/-}$ & $18 / 19$ & $19.74 \pm 7.68^{\mathrm{A}^{* *}}$ & 94.73 & 87 & 74 & 74 & 109 & 20 & 313 & 39 & 11 & 364 \\
\hline$q \mathrm{Cx} 43^{+/+}$ & $20 / 20$ & $9.78 \pm 5.86^{\mathrm{B}^{* *}}$ & 100 & 45 & 21 & 49 & 49 & 12 & 168 & 7 & 1 & 176 \\
\hline$+\mathrm{C} \times 43^{+/-}$ & $24 / 24$ & $13.48 \pm 7.62^{\mathrm{B}^{*}}$ & 100 & 75 & 39 & 64 & 96 & 18 & 278 & 9 & 5 & 292 \\
\hline $\mathrm{C}^{7} \mathrm{C} 43^{+/+}$ & $0 / 28$ & 0 & 0 & 0 & 0 & 0 & 0 & 0 & 0 & 0 & 0 & 0 \\
\hline $\mathrm{C}^{-1} \times 43^{+/-}$ & $0 / 32(31)$ & 0 & 0 & 0 & 0 & 0 & 0 & 0 & 0 & 0 & 0 & 0 \\
\hline $9 \mathrm{Cx} 43^{+/+}$ & 0/33 (32) & 0 & 0 & 0 & 0 & 0 & 0 & 0 & 0 & 0 & 0 & 0 \\
\hline$q \mathrm{C} \times 43^{+/-}$ & $0 / 20$ (19) & 0 & 0 & 0 & 0 & 0 & 0 & 0 & 0 & 0 & 0 & 0 \\
\hline
\end{tabular}

$\square$ tratados com uretana; $\square$ sem tratamento com uretana. Os camundongos foram sacrificados com 6 meses de idade com injeção intraperitoneal de Tiopental sódico $250 \mathrm{mg} / \mathrm{g}$ de peso vivo. Os resultados são Média \pm Desvio padrão de 26; $18 ; 23$ e 24 camundongos, respectivamente. Médias seguidas de mesma letra na mesma coluna, não diferem significativamente entre si pelo teste de Tukey ${ }^{*} P<0,05$; ${ }^{* *} P<0,001$. 
5.1.2.4 Incidência de lesões macroscópicas espontâneas nos camundongos Cx43 ${ }^{+/-}$

Este estudo foi conduzido com o intuito de se verificar o aparecimento espontâneo de nódulos pré-neoplásicos e neoplásicos nos camundongos Cx43+/- em função da deleção de um dos alelos desta Cx. Os resultados são apresentados na tabela 15. Nenhum dos camundongos apresentou nódulos espontâneos após as 25 semanas.

5.1.2.5 Quantificação das lesões pulmonares microscópicas em sistema de análise de imagens

Os resultados da quantificação, em sistema de análise de imagens, das lesões pulmonares observáveis ao microscópio, em camundongos $\mathrm{C} \times 43^{+/+}, \mathrm{C} \times 43^{+/-}$ machos ou fêmeas tratados com uretana e sacrificados após 25 semanas está descrito na tabela 16. 
Tabela 16 - Quantificação histológica, em sistema de análise de imagem, das lesões pulmonares em camundongos machos ou fêmeas $\mathrm{C} \times 43^{+/-}$ou $\mathrm{Cx} 43^{+/+}$ sacrificados após 25 semanas da injeção intraperitoneal com uretana

\begin{tabular}{ccccc}
\hline Grupos & $\begin{array}{c}\mathbf{N}^{\circ} \text {. de } \\
\text { camundongos } \\
\text { no grupo }\end{array}$ & $\begin{array}{c}\mathbf{N}^{\circ} \text {. Médio de } \\
\text { lesões por } \\
\text { animal }\end{array}$ & $\begin{array}{c}\mathbf{N}^{\circ} \text { total de } \\
\text { lesões no } \\
\text { grupo }\end{array}$ & $\begin{array}{c}\text { Área média das } \\
\text { lesões }\left(\mu \mathbf{m}^{2)}\right.\end{array}$ \\
\hline${ }^{\top} \mathrm{C} \times 43^{+/+}$ & 24 & $2.83 \pm 1.97$ & 68 & $81284,35 \pm 67568$ \\
\hline${ }^{\top} \mathrm{C} \times 43^{+/-}$ & 19 & $6.16 \pm 2.95^{*}$ & 143 & $130212,3 \pm 143812$ \\
\hline$+\mathrm{C} \times 43^{+/+}$ & 18 & $1.94 \pm 1.5$ & 35 & $48132,80 \pm 51320$ \\
\hline कCx43 & 21 & $3.14 \pm 1.74$ & 66 & $56679,09 \pm 517554$ \\
\hline${ }^{*}$ diferença estatisticamente significante quando comparado com os demais grupos.
\end{tabular}

Pôde-se constatar na tabela acima, que os camundongos machos Cx43 apresentaram maior número de lesões por grupo, quando comparados aos demais grupos. Este resultado está em acordo com os resultados macroscópicos. As fêmeas $\mathrm{C}_{4} 43^{+/-}$apresentaram também maior número de lesões pulmonares quando comparadas com as selvagens correspondentes, porém as médias não são estatísticamente significativas. Da mesma forma, camundongos machos e fêmeas $\mathrm{C} \times 43^{+/-}$apresentaram lesões maiores do que as dos $\mathrm{C} \times 43^{+/+}$correspondentes, porém a diferença não foi estatísticamente significativa para as fêmeas.

\subsubsection{Classificação histologica dos adenomas}

Tem sido proposto que as lesões pulmonares induzidas pela uretana podem ser classificadas dentro de três diferentes grupos histológicos os quais são apresentados na figura 22 (REHM, 1994). Os resultados obtidos utilizando-se tal 
classificação histológica são apresentados na tabela 17. Estes resultados foram comparados entre os grupos contendo os machos ou as fêmeas isoladamente. Os camundongos $\mathrm{C} \times 43^{+/-}$mostraram as maiores quantidades de adenomas papilíferos que os camundongos $\mathrm{C} \times 43^{+/+}$. O número de adenomas sólidos, o qual foi maior nas fêmeas $\mathrm{C} \times 43^{+/-}$, foi similar entre os machos de ambos os genótipos. Entretanto, a porcentagem de adenomas mistos mostrou-se superior nos camundongos machos $\mathrm{C} \times 43^{+/+}$que nos $\mathrm{C} \times 43^{+/-}$. Este último resultado foi oposto para as fêmeas uma vez que a porcentagem de adenomas mistos foi mais baixa nas fêmeas $\mathrm{C} \times 43^{+/-}$que nas fêmeas $\mathrm{C} \times 43^{+/+}$. Parece que a maior incidência de adenomas papilíferos coincide, de maneira geral, com o genótipo $\mathrm{C} \times 43^{+/}$. 

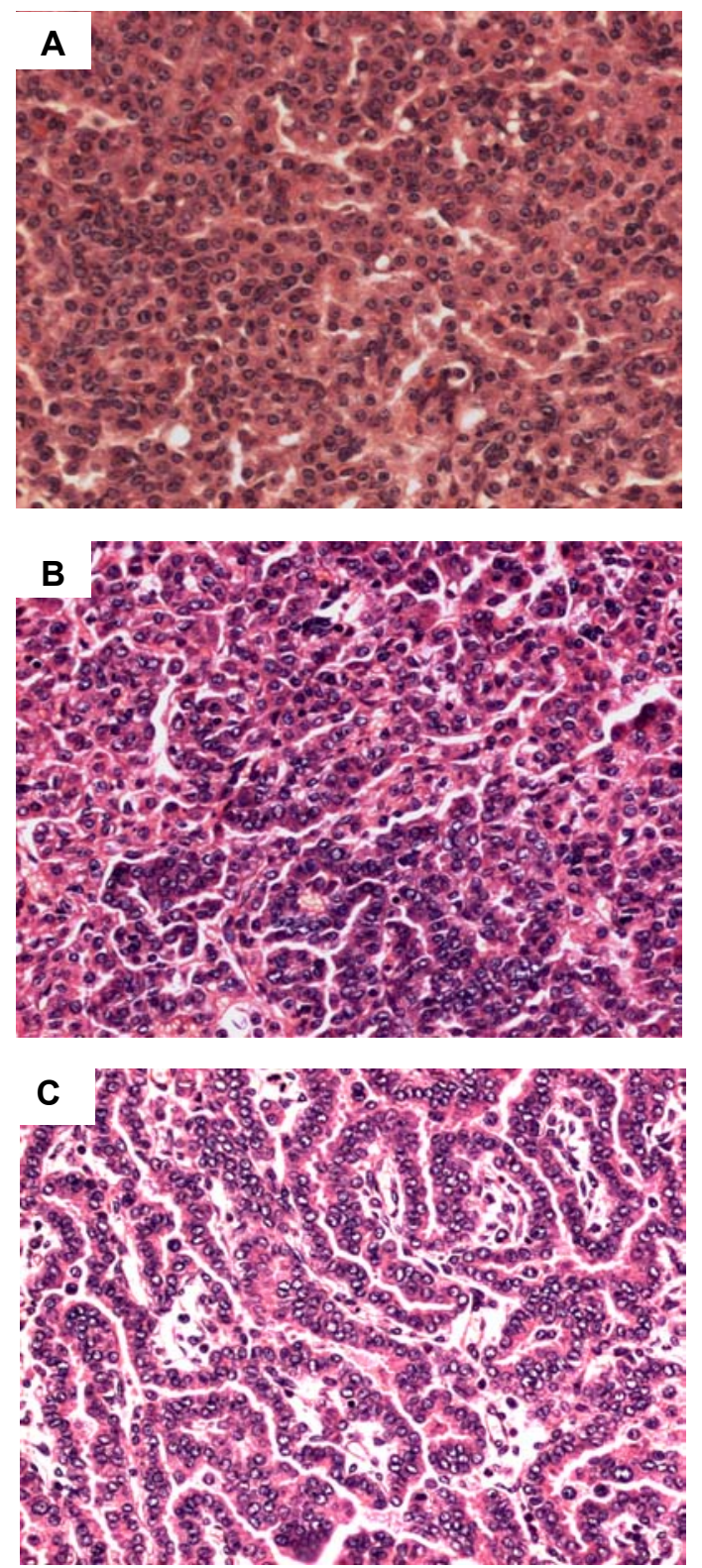

Figura 22 - Classificação histológica dos adenomas de camundongos com 25 semans após a injeção de uretana. Esta classificação foi estabelecida segundo os critérios publicados por Rehm et al., 1994. A. Adenoma sólido. B. Adenoma misto. C. Adenoma papilífero. Objetiva de 20X 
Tabela 17 - Classificação histológica dos adenomas pulmonares obtidos após 25 semanas da injeção de uretana

\begin{tabular}{|c|c|c|c|c|}
\hline \multirow{2}{*}{ Grupos } & \multicolumn{3}{|c|}{ Adenoma (\% do total de lesões) } & \multirow{2}{*}{$\begin{array}{l}\text { Número total } \\
\text { de lesões }\end{array}$} \\
\hline & Sólido & Misto & Papilífero & \\
\hline $\mathrm{C} \times 43^{+/+}$ & $41,1 \pm 13,1$ & $35,7 \pm 14,62^{*}$ & $23,2 \pm 8,49$ & 56 \\
\hline $\mathrm{J}^{1} \mathrm{C} \times 43^{+/-}$ & $42,4 \pm 18,4$ & $23,2 \pm 9,11$ & $34,3 \pm 16,44^{*}$ & 99 \\
\hline $9 \mathrm{Cx} 43^{+/+}$ & $71,4 \pm 21,3^{*}$ & $19,0 \pm 10,21$ & $9,5 \pm 4,73$ & 42 \\
\hline $9 \mathrm{Cx} 43^{+/-}$ & $52,3 \pm 14,1$ & $30,8 \pm 16,24^{*}$ & $16,9 \pm 5,47^{*}$ & 65 \\
\hline
\end{tabular}

Os caracteres diferentes na mesma coluna são significantes de acordo com o teste de Tukey-Kramer $(P<0,05)$. A análise estatística foi efetuada comparando-se apenas camundongos do mesmo sexo. Não se comparou machos e fêmeas.

\subsubsection{Quantificação das células positivas para o PCNA}

O resultado da quantificação das células positivas para o PCNA são apresentados na figura 23 e na tabela 18. Os camundongos machos e fêmeas $\mathrm{C} \times 43^{+/-}$apresentaram o maior índice de marcação de proliferação celular, tendo como base o PCNA, nos três tipos histológicos de adenomas após as 25 semanas de aplicação da uretana $(P<0,05)$. 

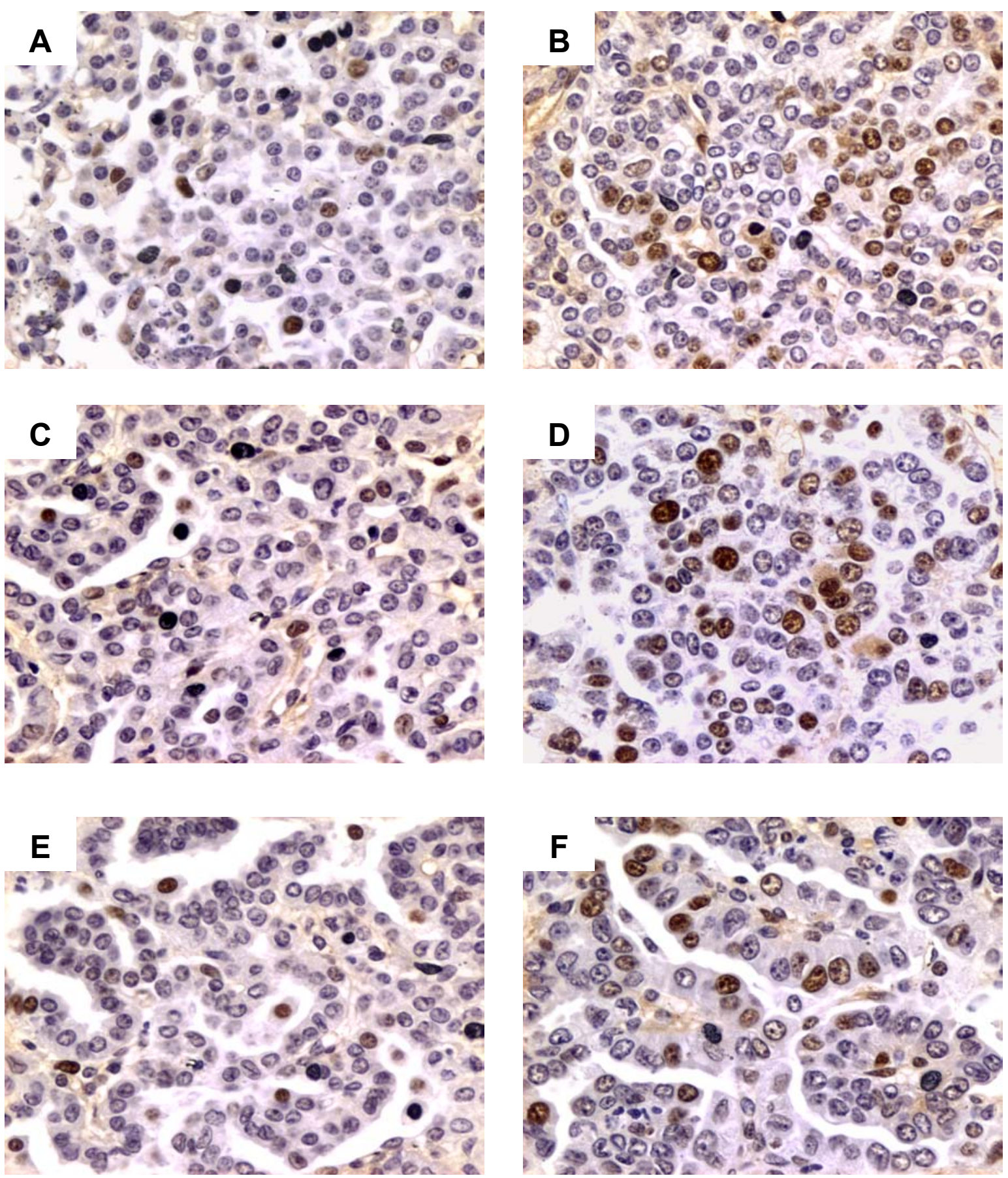

Figura 23 - Marcação do PCNA nos adenomas após 25 semanas do tratamento comuretana. A. Camundongo $\mathrm{C} \times 43^{+/+}$(Adenoma sólido). B. Camundongo $\mathrm{C} \times 43^{+/-}$(Adenoma sólido). C.Camundongo $\mathrm{C} \times 43^{+/+}$(Adenoma misto). D. Camundongo $\mathrm{C} \times 43^{+/-}$(Adenoma misto). E. Camundongo $\mathrm{Cx}_{43^{+/+}}$(Adenoma papilífero). F.Camundongo $\mathrm{Cx} 43^{+/-}$(Adenoma papilífero). Aumento 40X 
Tabela 18 - Quantificação dos núcleos imunomarcados para o PCNA nos tumores de pulmão dos camundongos após 25 semanas

\begin{tabular}{|c|c|c|c|}
\hline \multirow[t]{2}{*}{ Grupos } & \multicolumn{3}{|c|}{ Tipo morfológico dos tumores (Adenomas) } \\
\hline & Sólido (\%) & Papilífero (\%) & Misto (\%) \\
\hline${ }^{7} \mathrm{C} \times 43^{+/+}$ & $(n=11) 6,55 \pm 1,50$ & $(n=5) 11,89 \pm 2,13$ & $(n=8) 9,67 \pm 2,39$ \\
\hline${ }^{7} \mathrm{C} \times 43^{+/-}$ & $(n=19) 18,11 \pm 2,33^{*}$ & $(n=17) 20,17 \pm 4,90^{*}$ & $(n=11) 16,17 \pm 2,42^{*}$ \\
\hline $\mathrm{Cx} 43^{+/+}$ & $(n=14) 7,18 \pm 1,02$ & $(n=3) 9,06 \pm 1,03$ & $(n=4) 6,65 \pm 0,76$ \\
\hline $9 \mathrm{Cx} 43^{+/-}$ & $(n=8) 13,55 \pm 2,88^{*}$ & $(n=6) 18,42 \pm 6,92^{*}$ & $(n=12) 12,57 \pm 3,21^{*}$ \\
\hline
\end{tabular}

Os caracteres diferentes na mesma coluna são significantes de acordo com o teste de Tukey-Kramer $(P<0,05)$. Os resultados são média ( \pm desvio padrão) de 10 diferentes camundongos escolhidos ao acaso. $\mathrm{n}=$ número de lesões estudadas. 


\subsubsection{Imunoblote das Cxs 43, 26, 32 e 46}

\subsubsection{Imunoblote da Cx43}

O coração expressa os maiores níveis de expressão de Cx43 que qualquer outro órgão, assim, ele foi utilizado como controle para a otimização da reação. $\mathrm{O}$ conteúdo protéico da Cx43 mostrou-se em níveis mais baixos em extratos provenientes do coração de camundongos $\mathrm{C} \times 43^{+/-}$que nos extratos do coração dos camundongos $\mathrm{Cx}_{4} 3^{+/+}$(Figura 24). O mesmo padrão foi observado nos pulmões (Figura 25).

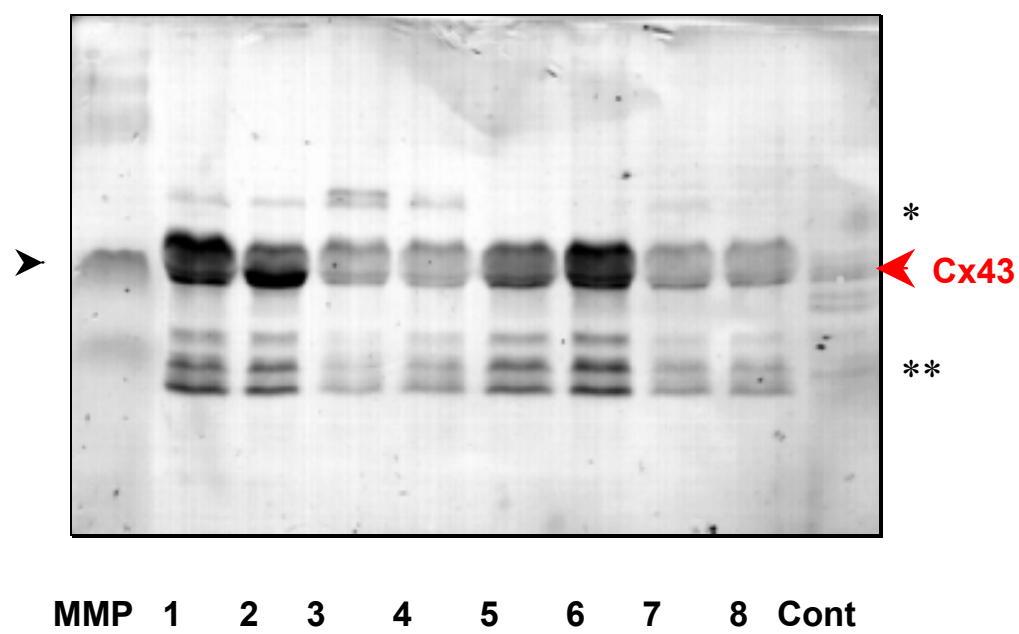

Figura 24 - Imunoblote no músculo cardíaco da Cx43. 1- ${ }^{1} \mathrm{C} \times 43^{+/+}$sem uretana; 2- $9 \mathrm{Cx} 43^{+/+}$sem uretana; 3- ${ }^{2} \mathrm{C} \times 43^{+/-}$sem uretana; 4- ${ }^{\circ} \mathrm{C} \times 43^{+/}$sem uretana; 5- ${ }^{-1} \mathrm{C} \times 43^{+/+}$com uretana; 6$\mathrm{C} \times 43^{+/+}$com uretana; 7- ${ }^{7} \mathrm{C} \times 43^{+/-}$com uretana; 8- ${ }^{\mathrm{C}} \mathrm{C} \times 43^{+/-}$com uretana; ContControle IAR20 (expressa a Cx43 endógenea, cedida pelo Dr. Marc Mesnil, Université de Poitiers). MMP. Marcador de peso molecular. A seta aponta para o marcador de peso molecular referente a $40 \mathrm{KDa}$. As imagens são resultados de três análises diferentes. * IgG; ** Produtos de degradação da Cx43 


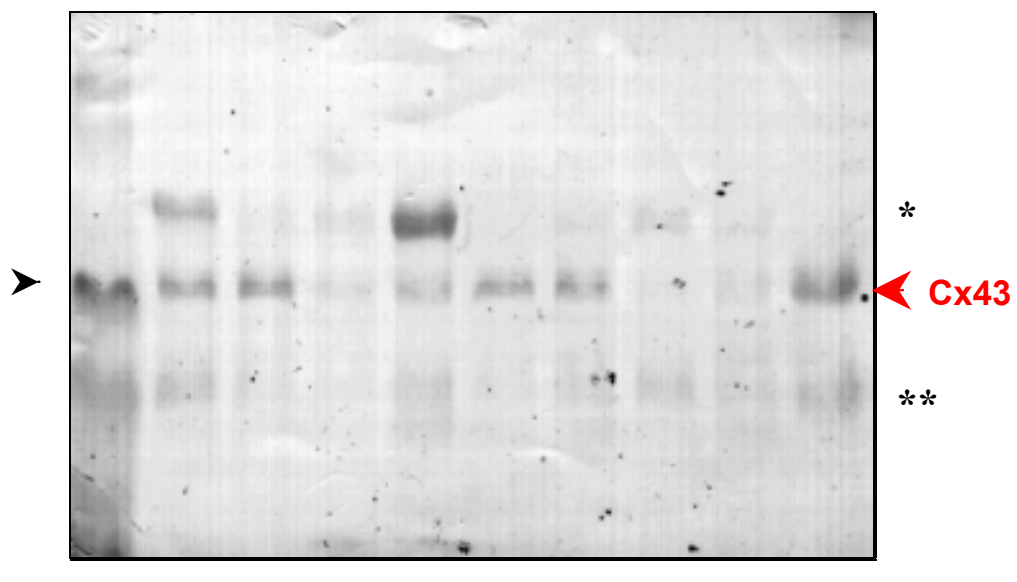

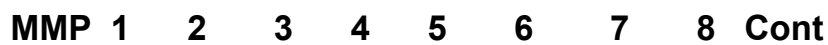

Figura 25 - Imunoblote no tecido pulmonar da Cx43. 1- ${ }^{\lambda} \mathrm{C} \times 43^{+/+}$sem uretana; 2- $\circ \mathrm{Cx} \times 3^{+/+}$sem uretana; 3- ${ }^{\lambda} \mathrm{C} \times 43^{+/-}$sem uretana; 4- $\rho \mathrm{C} \times 43^{+/-}$sem uretana; 5- ${ }^{2} \mathrm{C} \times 43^{+/+}$com uretana; 6${ }_{+} \mathrm{C} \times 43^{+/+}$com uretana; 7- ${ }^{1} \mathrm{C} \times 43^{+/-}$com uretana; 8- ${ }^{\circ} \mathrm{C} \times 43^{+/-}$com uretana; ContControle IAR20 (expressa a Cx43 endógenea, cedida pelo Dr. Marc Mesnil, Université de Poitiers). MMP. Marcador de peso molecular.. A seta preta aponta para o marcador de peso molecular referente a $40 \mathrm{KDa}$. As imagens são resultados de três análises diferentes. * IgG; ** Produtos de degradação da Cx43

Durante a síntese da Cx43, como qualquer proteína de membrana, ela é endereçada para a membrana plasmática (ver introdução página 35). Durante seu trajeto ela se apresenta com diferentes níveis de fosforilação, significado da fosforilação de serinas específicas. Assim, observam-se momentos chamados de Cx43-NP (não fosforilada), que rapidamente converte-se a dois estados de migração, na eletroforese, mais lentos (fosforilados) $\mathrm{Cx} 43-\mathrm{P}_{1}$ e $\mathrm{Cx} 43-\mathrm{P}_{2}$. Cx43- $\mathrm{P}_{1}$ é aquela conexina que chegou à membrana, já $\mathrm{Cx} 43-\mathrm{P}_{2}$ são as conexinas que compõem a placa juncional. Existe um quarto momento, o $\mathrm{Cx} 43-\mathrm{P}_{4}$, que representa a Cx que foi encaminhada para degradação. Na figura 24 observa-se que o coração tem os 3 padrões de fosforilação. Por outro lado, o tecido pulmonar (Figura 25) apresenta apenas dois estados de fosforilação, um não fosforilado (Cx43-NP) e outro fosforilado. Em função da quantidade de Cx43-P2, maior é o turnover da mesma, conseqüentemente, maiores quantidades de produtos de degradação $\left(\mathrm{Cx} 43-\mathrm{P}_{4}\right)$ podem ser registradas nos Imunoblotes, observar ** nas figuras 24 e 25. 
5.1.5.2 Imunoblote da Cx26, 32 e 46

As marcações referentes às Cx26, 32 e 46 encontram-se nas figuras 26, 27 e 28, respectivamente. Tanto a Cx26 quanto a $\mathrm{Cx32}$ apresentaram duas regiões conhecidas de reconhecimento pelos anticorpos, ou seja, a marcação característica na altura compreendida entre 25 a $35 \mathrm{KDa}$ e uma banda freqüentemente marcada na altura de $47 \mathrm{KDa}$. Esta banda de maior peso molecular tem sido referida como um dímero (resultado de interação com outras proteínas) muito bem descrito no trabalho publicado por Hertezberg e Skibbens (1984), e é característico de alguns tecidos. Como se pode observar, para o fígado, utilizado como controle positivo da reação, este dímero não é observado (Figuras 26 e 27 controles). Nas amostras provenientes dos camundongos que não receberam o tratamento com a uretana, o dímero referente às Cx26 e 32 é mais intensa que após o tratamento com a uretana. Também se pode observar que em ambas as conexinas, nas fêmeas $\mathrm{C} \times 43^{+/+} \mathrm{e}$ $\mathrm{C} \times 43^{+/-}$há um visível aumento na intensidade deste dímero após o tratamento com a uretana. Outra característica é o fato das fêmeas $\mathrm{C} \times 43^{+/-}$, não tratadas com uretana, apresentarem uma marcação mais intensa que os machos Cx43 ${ }^{+/-}$(Figuras 26 e 27, linhas 3 e 4) o não se observa entre os camundongos $C \times 43^{+/+}$(Linhas 1 e 2). 


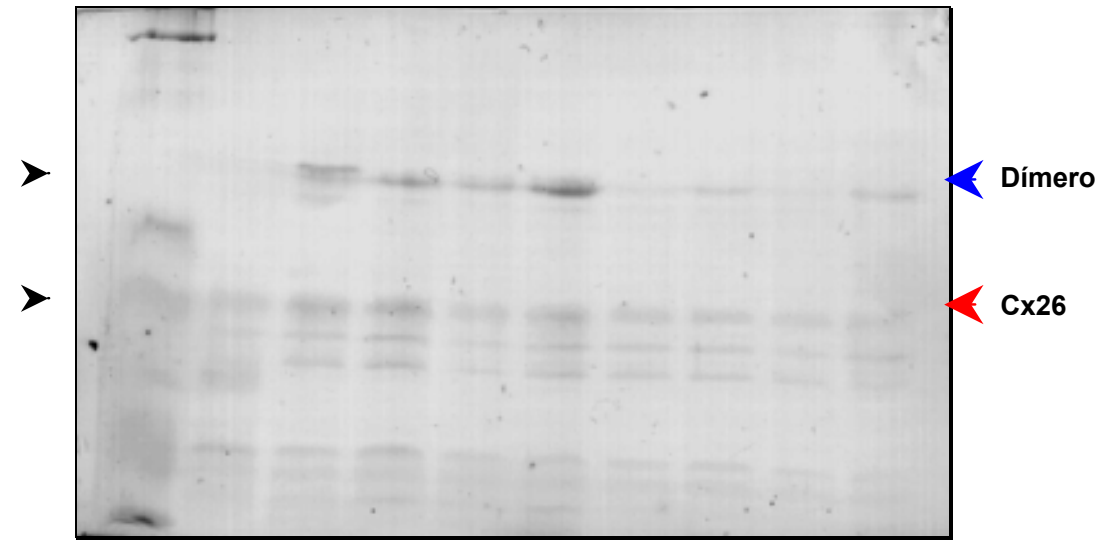

$\begin{array}{lllllllll}\text { MMP Cont } & 1 & 2 & 3 & 4 & 5 & 6 & 7 & 8\end{array}$

Figura 26 - Imunoblote no tecido pulmonar da Cx26 mostrando que esta Cx foi afetada pelo tratamento com uretana. 1- ${ }^{1} \mathrm{C} \times 43^{+/+}$sem uretana; 2- $\rho \mathrm{C} \times 43^{+/+}$sem uretana; 3${ }^{\top} \mathrm{C} \times 43^{+/-}$sem uretana; 4- $9 \mathrm{C} \times 43^{+/-}$sem uretana; 5- ${ }^{\lambda} \mathrm{C} \times 43^{++/}$com uretana; 6- $\rho \mathrm{C} \times 43^{+/+}$ com uretana; 7- ${ }^{\lambda} \mathrm{C} \times 43^{+/-}$com uretana; 8- $+\mathrm{C} \times 43^{+/-}$com uretana; Cont- Controle Fígado (expressa a Cx26 endógena). MMP. Marcador de peso molecular. As setas pretas apontam para o marcador de peso molecular referente a $30 \mathrm{KDa}$ e a $47 \mathrm{KDa}$. As imagens são resultados de três análises diferentes 


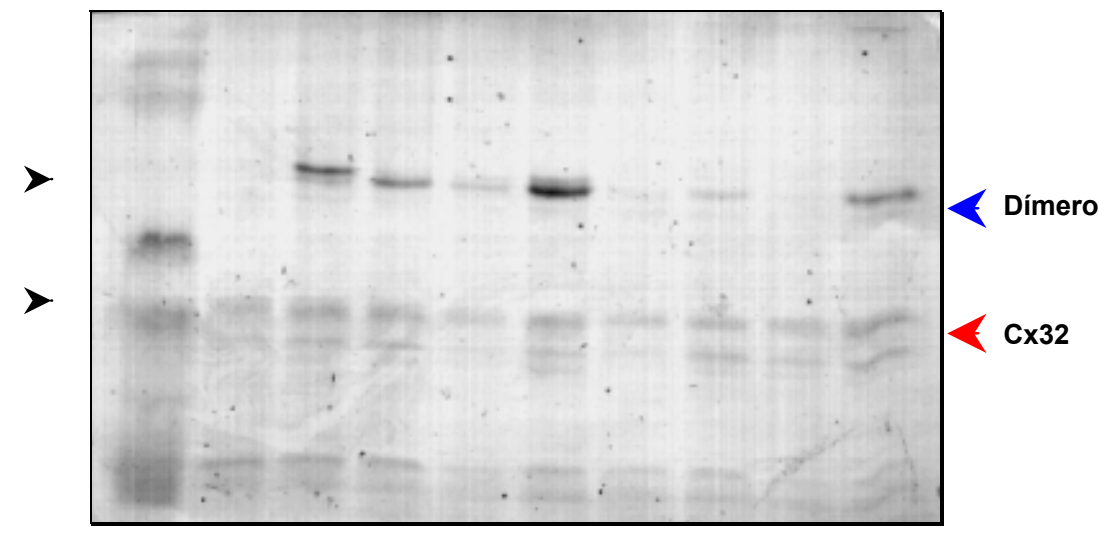

$\begin{array}{lllllllll}\text { MMP Cont } & 1 & 2 & 3 & 4 & 5 & 6 & 7 & 8\end{array}$

Figura 27 - Imunoblote no tecido pulmonar da Cx32 mostrando que esta Cx, principalmente nos machos, foi afetada pelo tratamento com uretana. 1- ${ }^{2} \mathrm{C} \times 43^{+/+}$sem uretana; 2- $\odot \mathrm{Cx} 43^{+/+}$ sem uretana; 3- ${ }^{\lambda} \mathrm{C} \times 43^{+/-}$sem uretana; 4- $\rho \mathrm{C} \times 43^{+/-}$sem uretana; 5- ${ }^{\lambda} \mathrm{C} \times 43^{+/+} \mathrm{com}$ uretana; 6- $\rho \mathrm{Cx} 43^{+/+}$com uretana; 7- ${ }^{2} \mathrm{C} \times 43^{+/-}$com uretana; 8- $q \mathrm{C} \times 43^{+/-}$com uretana; Cont- Controle- Fígado (expressa a Cx32 endógenea). ). MMP. Marcador de peso molecular. As setas pretas apontam para o marcador de peso molecular referente a 30 $\mathrm{KDa}$ e a $47 \mathrm{KDa}$. As imagens são resultados de três análises diferentes

A imunomarcação para Cx46 pode ser observada na figura 28. Esta conexina pode ser observada intensamente em todos os camundongos não submetidos ao tratamento com a uretana (Linhas 1, 2, 3 e 4). No entanto, após o tratamento ela completamente desapareceu de membrana de PVDF (Linhas 5, 6, 7 e 8), não apresentando diferença entre os sexos. 


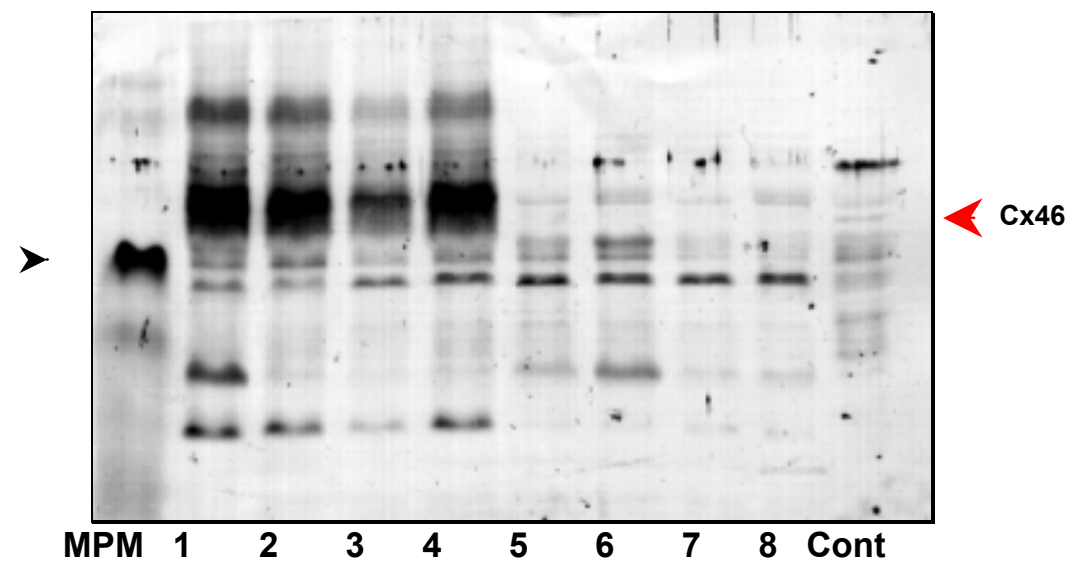

Figura 28 - Imunoblote no tecido pulmonar da Cx46 mostrando que esta Cx foi afetada pelo tratamento com uretana. 1- ${ }^{\lambda} \mathrm{Cx} 43^{+/+}$sem uretana; 2- $\odot \mathrm{Cx} 43^{+/+}$sem uretana; 3${ }^{2} \mathrm{C} \times 43^{+/-}$sem uretana; 4- ${ }^{\circ} \mathrm{C} \times 43^{+/-}$sem uretana; 5- ${ }^{1} \mathrm{C} \times 43^{+/+}$com uretana; 6- $+\mathrm{C} \times 43^{+/+}$ com uretana; 7- ${ }^{1} \mathrm{C} \times 43^{+/-}$com uretana; 8- $0 \mathrm{C} \times 43^{+/-}$com uretana; Cont- ControleHeLa46 (Células de HeLa transfectadas com o gene da Cx46). MMP. Marcador de peso molecular. A seta preta aponta para o marcador de peso molecular referente a 40 $\mathrm{KDa}$ e a vermelha para a região onde se encontra a Cx46. As imagens são resultados de três análises diferentes 


\subsubsection{Resultados do RT-PCR}

O end point do PCR em tempo real é o limiar de corte (thresh-old cycle) ou $C_{\mathrm{T}}$. $\mathrm{O} C_{\mathrm{T}}$ é determinado a partir do plote linear de valores logarítmicos do sinal de PCR versus o número de ciclo. Assim, o $C_{\top}$ é um valor exponencial e não um valor linear. Por esta razão, qualquer apresentação estatística utilizando valores brutos do $C_{\top}$ deve ser evitada. Os resultados das análises estatísticas aqui apresentadas foram aplicados apenas sobre os dados de $\Delta C t$. Isto foi levado em consideração pelo fato dos cálculos utilizados para a normalização aumentarem a variância dos resultados em cerca de $15 \%$ não permitindo se verificar qualquer diferença estatística (LIVAK et al., 2001). Assim, é aconselhável realizar a análise estatística com os valores do $\Delta C t$. Ratificando que uma diferença de $0,5 x$ entre uma amostra e outra (equivalente a $1 \mathrm{C}_{\mathrm{T}}$ de diferença) representa o dobro da expressão do gene. Como calibrador (necessário para a normalização dos resultados), foi utilizado os resultados de expressão das fêmeas não tratadas com uretana (Cx43 $\left.{ }^{+/+n u}\right)$.

\subsubsection{PCR em tempo real para a Cx43}

Após as análises de PCR em tempo real, os camundongos $\mathrm{C} \times 43^{+/-}$ apresentaram menor expressão do gene da Cx43 quando comparados aos camundongos $\mathrm{C} \times 43^{+/+}$em todas as condições analisadas (Tabela 19). Sem o tratamento com a uretana os camundongos $\mathrm{Cx} 43^{+/-}$tem aproximadamente $50 \%$ da expressão da Cx43. Após o tratamento com a uretana a expressão entre machos e fêmeas $\mathrm{C} \times 43^{+/+}$é a mesma e aumenta em relação aos não tratados. No entanto, 
somente as fêmeas $\mathrm{Cx} 43^{+/-}$mostraram um aumento na expressão da Cx43 após o tratamento.

Para estudar a expressão da Cx43 nos tumores nós escolhemos aqueles maiores que $3 \mathrm{~mm}$, o que facilitaria a sua extração e aumentaria a quantidade de RNA total extraído. Os maiores tumores também foram classificados como sendo papilíferos. Nestas amostras nós não detectamos qualquer nível de expressão da Cx43 em camundongos $\mathrm{C} \times 43^{+/-}$. Mas, em camundongos $\mathrm{C} \times 43^{+/+}$a fêmeas apresentaram os maiores valores de expressão. 
Tabela 19 - Dados referentes as replicatas onde o target $(\mathrm{Cx} 43)$ e o gene de referência (GAPDH) foram amplificados em wells diferentes ${ }^{a}$

\begin{tabular}{|c|c|c|c|c|c|}
\hline Grupos & $\mathrm{Cx43} C_{T}$ & GAPDH $C_{T}$ & $\begin{array}{c}\Delta C_{T} \text { (Méd. } \\
\text { Cx43 } C_{T}- \\
\text { Méd. GAPDH } \\
C_{T} \text { ) }\end{array}$ & $\begin{array}{c}\Delta \Delta \boldsymbol{C}_{T} \text { (Méd. } \\
\Delta \boldsymbol{C}_{T}- \\
\underset{\mathrm{Cx} 4 \mathrm{C}_{T+/+}}{\operatorname{Méd}}\end{array}$ & $\begin{array}{c}\text { Quantidade de } \\
\text { Cx43 realtiva } \\
\text { normalizada à } \\
\text { fêmea } \mathrm{Cx}_{43^{+++w u}} \\
2^{-\Delta \Delta C_{T}}\end{array}$ \\
\hline $\mathrm{C} \times 43^{+/+n u}$ & $31,6 \pm 0,4$ & $24,9 \pm 0,2$ & $6,7 \pm 0,2^{B}$ & $-0,3 \pm 0,4$ & 1,2 \\
\hline${ }^{7} \mathrm{C} \times 43^{+/-n u}$ & $32,4 \pm 0,7$ & $24,4 \pm 0,2$ & $8,1 \pm 0,7^{A}$ & $1,1 \pm 0,8$ & 0,5 \\
\hline$+\mathrm{Cx} 43^{+/+n u}$ & $30,2 \pm 0,2$ & $23,3 \pm 0,1$ & $6,9 \pm 0,2^{B}$ & 0,0 & 1,0 \\
\hline$+\mathrm{C} \times 43^{+/-\mathrm{nu}}$ & $31,4 \pm 0,2$ & $23,7 \pm 0,3$ & $7,7 \pm 0,3^{A}$ & $0,7 \pm 0,2$ & 0,6 \\
\hline${ }^{7} \mathrm{C} \times 43^{+/+w u}$ & $27,8 \pm 0,1$ & $21,7 \pm 0,3$ & $6,1 \pm 0,2^{B}$ & $-0,9 \pm 0,3$ & 1,8 \\
\hline${ }^{7} \mathrm{C} \times 43^{+/-w u}$ & $28,7 \pm 0,5$ & $20,9 \pm 0,3$ & $7,9 \pm 0,4^{A}$ & $1,1 \pm 0,3$ & 0,5 \\
\hline$+\mathrm{C} \times 43^{+/+w u}$ & $28,0 \pm 0,4$ & $22,5 \pm 0,4$ & $6,2 \pm 0,6^{B}$ & $-0,8 \pm 0,5$ & 1,8 \\
\hline $9 \mathrm{C} \times 43^{+/-w u}$ & $29,3 \pm 0,5$ & $22,2 \pm 0,2$ & $7,2 \pm 0,6^{A}$ & $0,2 \pm 0,8$ & 1,0 \\
\hline $\mathrm{C} \times 43^{+/+\mathrm{tu}}$ & $31,4 \pm 0,3$ & $21,7 \pm 0,4$ & $9,7 \pm 0,4^{A}$ & $2,8 \pm 0,3$ & 0,1 \\
\hline${ }^{\lambda} \mathrm{C} \times 43^{+/- \text {tu }}$ & NDT & $31,7 \pm 0,4$ & - & - & NDT \\
\hline$+\mathrm{Cx} 43^{+/+ \text {tu }}$ & $30,6 \pm 0,6$ & $22,6 \pm 0,5$ & $8,0 \pm 0,1^{B}$ & $1,1 \pm 0,3$ & 0,5 \\
\hline $9 \mathrm{Cx} 43^{+/- \text {tu }}$ & NDT & $33,2 \pm 0,2$ & - & - & NDT \\
\hline
\end{tabular}

a Utilizando transcriptase reversa, o cDNA foi sintetizado a partir de $500 \mu \mathrm{g}$ de RNA total. Alíquotas de cDNA foram usadas com molde para o PCR em tempo real em reações contendo os primers e o probe para Cx43 ou primers e probe para GAPDH. Cada reação continha cDNA derivado de 1 ng de RNA total. Quatro replicatas de cada ração foi realizada. $\mathbf{N u}=$ não tratado; $\mathbf{w u}=$ tratado com uretana; tu = amostra de tumor; NDT = não detectado. 
5.1.6.2 PCR em tempo real para as Cx26, Cx32 e Cx46

5.1.6.2.1 Resultados referentes à expressão da Cx26 pela técnica de Real Time PCR

Os resultados de expressão da Cx26 são apresentados nas tabelas, 20, 21, 22 e 23. Nenhuma diferença estatística foi observada entre os $\Delta$ Cts da Cx26 nos indivíduos tratados ou não com uretana, ou nos adenomas. Com relação à sua expressão nos camundongos não tratados, a expressão foi maior entre os machos de ambos os genótipos. Nos camundongos $\mathrm{C} \times 43^{+/-}$a expressão foi cerca de 4 vezes maior que nas fêmeas $\mathrm{C} \times 43^{+/-}$. Entre os machos $\mathrm{C} \times 43^{+/+}$, a expressão comparada a das fêmeas de mesmo genótipo foi 9 vezes maior.

Após o tratamento com uretana, observou-se uma redução de aproximadamente 2 vezes entre os machos. As fêmeas foram mais responsivas à uretana, apresentando uma expressão de aproximadamente 14 vezes e 5 vezes entre as fêmeas $\mathrm{C} \times 43^{+/+}$e $\mathrm{C} \times 43^{+/-}$, respectivamente.

Obedecendo ao mesmo padrão de expressão que no tecido normal, os adenomas mostraram expressões mais intensas desta Cx entre as fêmeas. Enquanto a média de expressão nos adenomas provenientes dos machos ficou entre 3,5 vezes, nas fêmeas foi de 6,5 vezes.

Para se avaliar a suceptibilidade ou quão efetiva foi à resposta da Cx26 ao tratamento com uretana, as tabelas 21 e 22 foram idealizadas. Na tabela 21 pode-se observar, isoladamente, que as fêmeas são mais responsivas à uretana. Na tabela 22, verifica-se que os machos tem diminuição de 2 vezes na expressão desta $C x$ 
após o tratamento. Já as fêmeas aumentam significativamente a expressão quando tratadas com uretana. A expressão da Cx26 entre as fêmeas $C \times 43^{+/+}$não tratadas, representa cerca de 0,07 vezes a expressão dela após o tratamento. Esta proporção é praticamente mantida nas fêmeas $\mathrm{Cx} 43^{+/-}$em cerca de 0,21 vezes a expressão do camundongo não tratado.

Nós apresentamos na tabela 23 os resultados em que a expressão da Cx26 foi comparada à expressão da Cx43. Para a confecção desta tabela, consideramos a eficiência da transcrição reversa e da PCR de 100\%. A última coluna desta tabela apresenta a normalização entre as Cxs. Entre os camundongos não tratados, apenas os machos $\mathrm{C} \times 43^{+/+}$mostraram expressão superior a da $\mathrm{C} \times 43$. A diferença de expressão entre estas duas Cxs foi maior entre as fêmeas.

Após o tratamento com uretana, como já mencionado acima, ocorreu uma diminuição na expressão da Cx26. Isto fica mais evidente nesta tabela. Tanto os machos $\mathrm{C} \times 43^{+/+}$quanto os $\mathrm{C} \times 43^{+/-}$apresentam expressão menor comparada a da C43. A diferença observada entre as duas Cxs antes do tratamento, desaparece após as 25 semanas da injeção com uretana. Isto reinforça a tese de que a Cx26, principalmente nas fêmeas, é mais responsiva à uretana; contribuindo para a resistência a formação de tumores entre elas.

Esta relação também foi efetuada entre os tumores, quando possível. Esta análise mostrou que a Cx26 tem expressão superior a da Cx43 nos adenomas e pode ter conseqüências significativas na invasão como será discutido adiante. 
Tabela 20 - Tratamento dos resultados de real time PCR onde o target (Cx26) e a referência (GAPDH) foram amplificados em wells separados ${ }^{a}$

\begin{tabular}{|c|c|c|c|c|c|}
\hline Grupos & $\mathrm{Cx} 26 \mathrm{C}_{T}$ & GAPDH $C_{T}$ & $\begin{array}{l}\Delta C_{T} \text { (Média } C_{T} \\
\text { Cx26 - Média } \\
C_{T} \text { GAPDH) }\end{array}$ & 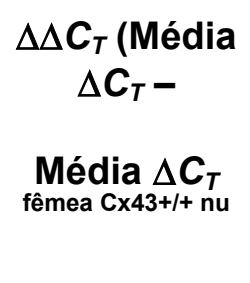 & $\begin{array}{c}\text { Expressão da } \\
\text { Cx26 } \\
\text { normalizada } \\
\text { com a fêmea } \\
\text { Cx43 } \\
\left(2^{+/+n u}\right. \\
\left(2^{-\Delta \Delta C}\right)\end{array}$ \\
\hline $\mathrm{Cx}^{2} 3^{+/+ \text {nu }}$ & $33,12 \pm 0,06$ & $26,31 \pm 0,34$ & $6,53 \pm 0,51^{A}$ & $-3,20 \pm 0,51$ & $9,48 \pm 3,28$ \\
\hline $\mathbf{C} \times \mathbf{4 3}^{+/-n u}$ & $33,84 \pm 0,28$ & $25,86 \pm 0,25$ & $7,98 \pm 1,23^{A}$ & $-1,75 \pm 1,23$ & $4,36 \pm 3,92$ \\
\hline$\uparrow \mathbf{C x} 43^{+/+n u}$ & $31,78 \pm 0,09$ & $22,05 \pm 0,01$ & $9,73 \pm 1,12^{A}$ & $0,00 \pm 0,00$ & $1,00 \pm 0,00$ \\
\hline$\oint \mathbf{C x} 43^{+/- \text {nu }}$ & $34,45 \pm 0,08$ & $25,08 \pm 0,43$ & $9,37 \pm 1,17^{\mathrm{A}}$ & $-0,36 \pm 1,17$ & $1,28 \pm 2,24$ \\
\hline $\mathbf{C} \times 43^{+/+w u}$ & $29,48 \pm 0,27$ & $21,47 \pm 0,15$ & $8,01 \pm 1,22^{A}$ & $-1,72 \pm 1,22$ & $3,90 \pm 2,94$ \\
\hline $\mathbf{C x 4 3 ^ { + / - w u }}$ & $31,45 \pm 0,13$ & $22,95 \pm 0,12$ & $8,50 \pm 1,35^{A}$ & $-1,24 \pm 1,35$ & $2,89 \pm 2,37$ \\
\hline${ }_{+} \mathbf{C} \times 43^{+/+w u}$ & $33,89 \pm 0,10$ & $27,53 \pm 0,32$ & $5,91 \pm 0,27^{A}$ & $-3,82 \pm 0,27$ & $14,25 \pm 2,64$ \\
\hline$+\mathbf{C x} 43^{\text {t/wu }}$ & $28,53 \pm 0,09$ & $21,44 \pm 0,56$ & $7,09 \pm 0,11^{\mathrm{A}}$ & $-2,64 \pm 0,11$ & $6,24 \pm 0,49$ \\
\hline $\mathbf{C} \times \mathbf{4 3}^{\text {t/+tu }}$ & $31,96 \pm 0,35$ & $24,42 \pm 0,20$ & $8,06 \pm 1,08^{A}$ & $-1,58 \pm 1,08$ & $3,65 \pm 2,49$ \\
\hline $\mathrm{C} \times 43^{+1-\text { tu }}$ & $37,18 \pm 1,32$ & $32,96 \pm 0,18$ & $7,88 \pm 1,54^{A}$ & $-1,85 \pm 1,54$ & $3,61 \pm 2,56$ \\
\hline$q \mathbf{C x} 43^{+/+ \text {tu }}$ & $35,15 \pm 0,11$ & $29,52 \pm 0,27$ & $7,21 \pm 1,94^{A}$ & $-2,35 \pm 1,94$ & $8,57 \pm 8,99$ \\
\hline$\uparrow \mathbf{C x} 43^{\text {t/-tu }}$ & $32,73 \pm 0,46$ & $25,26 \pm 0,12$ & $7,47 \pm 1,73^{A}$ & $-2,26 \pm 1,73$ & $4,79 \pm 1,89$ \\
\hline
\end{tabular}

a Usando transcriptase reversa; cDNA foi sintetizado a partir de $500 \mu \mathrm{g}$ de RNA total. Alíquotas de cDNA foram utilizadas como template para as reações de real-time PCR contendo os primers e as probe para a Cx26 ou primers e probe para o GAPDH. Cada reação continha cDNA correspondente a $1 \mathrm{ng}$ de RNA total. Quatro replicatas de cada grupo foram realizadas. nu = não tratada com uretana; $\mathbf{w u}=$ tratado com uretana; $\mathbf{t u}=$ amostra de tumor (>3mm de diâmetro); NDT = não detectado (onde indicado). 
Tabela 21 - Tratamento dos resultados de real time PCR onde o target (Cx26) e a referência (GAPDH) foram amplificados em wells separados ${ }^{a}$. Análise estatística dentro de cada grupo (Com uretana ou sem uretana)

\begin{tabular}{|c|c|c|}
\hline Grupos & $\Delta C_{T} \mathrm{Cx26}$ & $\begin{array}{c}\text { Expressão da Cx26 normalizada com } \\
\text { a fêmea } \mathrm{Cx} 43^{+/+n u} \\
\left(2^{-\Delta \Delta C} \mathrm{~T}\right)\end{array}$ \\
\hline $\mathrm{C} \times 43^{+/+n u}$ & $6,53 \pm 0,51^{A}$ & $9,48 \pm 3,28$ \\
\hline$\sigma^{\top} \mathrm{C} \times 43^{+/-n u}$ & $7,98 \pm 1,23^{\mathrm{A}}$ & $4,36 \pm 3,92$ \\
\hline$q \mathrm{C} \times 43^{+/+n u}$ & $9,73 \pm 1,12^{\mathrm{A}}$ & $1,00 \pm 0,00$ \\
\hline$+\mathrm{C} \times 43^{+/-n u}$ & $9,37 \pm 1,17^{\mathrm{A}}$ & $1,28 \pm 2,24$ \\
\hline $\mathrm{C} \times 43^{+/+w u}$ & $8,01 \pm 1,22^{A}$ & $3,90 \pm 2,94$ \\
\hline${ }^{\lambda} \mathrm{C} \times 43^{+-/ w u}$ & $8,50 \pm 1,35^{\mathrm{A}}$ & $2,89 \pm 2,37$ \\
\hline $9 \mathrm{Cx} 43^{+/+w u}$ & $5,91 \pm 0,27^{A}$ & $14,25 \pm 2,64$ \\
\hline $9 \mathrm{C} \times 43^{+/-w u}$ & $7,09 \pm 0,11^{\mathrm{A}}$ & $6,24 \pm 0,49$ \\
\hline
\end{tabular}

Resultados seguidos de caracteres iguais não diferem entre si. nu = não tratada com uretana; $\mathbf{w u}=$ tratado com uretana; tu = amostra de tumor ( $>3 \mathrm{~mm}$ de diâmetro); NDT = não detectado (onde indicado). 
Tabela 22 - Tratamento dos resultados de real time PCR onde o target (Cx26) e a referência (GAPDH) foram amplificados em wells separados ${ }^{a}$. Análise estatística comparando os genótipos dentro dos diferentes tratamentos (Com uretana ou sem uretana)

\begin{tabular}{|c|c|c|c|}
\hline Grupos & $\Delta C_{T} \mathrm{Cx26}$ & $\begin{array}{l}\text { Expressão da Cx26 normalizada } \\
\text { com a fêmea } C \times 43^{+++ \text {nu }} \\
\qquad\left(2^{-\Delta \Delta C}\right)\end{array}$ & $\begin{array}{l}\text { Diferença de } \\
\text { expressão em } \\
\text { relação ao indivíduo } \\
\text { não tratado }\end{array}$ \\
\hline${ }^{7} \mathrm{C} \times 43^{+/+n u}$ & $6,53 \pm 0,51^{\mathrm{B}}$ & $9,48 \pm 3,28$ & 2,43 \\
\hline $\mathrm{C} \times 43^{+/+w u}$ & $8,01 \pm 1,22^{\mathrm{A}}$ & $3,90 \pm 2,94$ & \\
\hline $\mathrm{J}^{7} \mathrm{x} 43^{+/-n u}$ & $7,98 \pm 1,23^{A}$ & $4,36 \pm 3,92$ & 1,51 \\
\hline${ }^{7} \mathrm{C} \times 43^{+/-w u}$ & $8,50 \pm 1,35^{A}$ & $2,89 \pm 2,37$ & \\
\hline$+\mathrm{C} \times 43^{+/+n u}$ & $9,73 \pm 1,12^{A}$ & $1,00 \pm 0,00$ & 0,07 \\
\hline$+\mathrm{C} \times 43^{+/+w u}$ & $5,91 \pm 0,27^{\mathrm{B}}$ & $14,25 \pm 2,64$ & \\
\hline $9 \mathrm{Cx} 43^{+/-n u}$ & $9,37 \pm 1,17^{\mathrm{A}}$ & $1,28 \pm 2,24$ & 0,21 \\
\hline$+\mathrm{Cx} 43^{+/-w u}$ & $7,09 \pm 0,11^{\mathrm{B}}$ & $6,24 \pm 0,49$ & \\
\hline
\end{tabular}

Resultados seguidos de caracteres iguais não diferem entre si. nu = não tratada com uretana; $\mathbf{w u}=$ tratado com uretana; tu = amostra de tumor $(>3 \mathrm{~mm}$ de diâmetro); NDT = não detectado (onde indicado). 
Tabela 23 - Tratamento dos resultados de real time PCR onde o $\Delta \mathrm{Ct}$ do target (Cx26) foi comparado ao $\Delta \mathrm{Ct}$ da $\mathrm{Cx} 43$ no respectivo tratamento

\begin{tabular}{|c|c|c|c|c|c|}
\hline Grupos & $\Delta C_{T} \mathrm{Cx26}$ & $\Delta C_{T} \mathrm{Cx} 43$ & $\begin{array}{c}\text { Comparação } \\
\Delta \Delta C_{T}\left(\Delta C_{T}\right. \\
C_{x 26}-\Delta C_{T} \\
\text { Cx43) }\end{array}$ & $\begin{array}{c}\text { Expressão da } \\
\text { Cx26 } \\
\text { normalizada com } \\
\text { a Cx43 }\left(2^{-\Delta \Delta C} \mathrm{~T}\right)\end{array}$ & $\begin{array}{c}\text { Expressão } \\
\text { normalizada da } \\
\text { Cx43 (1) / } \\
\text { Expressão } \\
\text { normalizada da } \\
\text { Cx26 }\end{array}$ \\
\hline $\mathrm{C} \times 4^{+/+n u}$ & $6,53 \pm 0,51$ & $6,65 \pm 0,23$ & $-0,15 \pm 0,13$ & $1,11 \pm 0,10$ & $0,90 \pm 0,08^{B}$ \\
\hline$C \times 43^{+1-n u}$ & $7,98 \pm 1,23$ & $8,05 \pm 0,66$ & $1,08 \pm 0,99$ & $0,53 \pm 0,34$ & $2,37 \pm 1,52^{B}$ \\
\hline$\uparrow \mathbf{C x} \mathbf{4 3}^{+/+n u}$ & $9,73 \pm 1,12$ & $6,92 \pm 0,17$ & $1,87 \pm 0,27$ & $0,28 \pm 0,05$ & $3,69 \pm 0,68^{A}$ \\
\hline$q \mathbf{C x 4 3 ^ { + / - n u }}$ & $9,37 \pm 1,17$ & $7,66 \pm 0,27$ & $2,42 \pm 0,27$ & $0,19 \pm 0,03$ & $5,40 \pm 1,00^{A}$ \\
\hline $\mathrm{Cx}_{43^{+++w u}}$ & $8,01 \pm 1,22$ & $6,07 \pm 0,17$ & $2,03 \pm 1,31$ & $0,30 \pm 0,24$ & $4,94 \pm 3,95^{\mathrm{A}}$ \\
\hline $\mathrm{Cx} 43^{\text {t-wu }}$ & $8,50 \pm 1,35$ & $7,72 \pm 0,32$ & $0,53 \pm 1,10$ & $0,79 \pm 0,55$ & $1,66 \pm 1,15^{\mathrm{A}}$ \\
\hline$甲 \mathbf{C x} \mathbf{4 3}^{+++w u}$ & $5,91 \pm 0,27$ & $6,15 \pm 0,58$ & $-0,10 \pm 0,12$ & $1,07 \pm 0,09$ & $0,94 \pm 0,08^{A}$ \\
\hline${ }_{+} \mathbf{C x} \mathbf{4 3}^{+/-w u}$ & $7,09 \pm 0,11$ & $7,41 \pm 0,63$ & $0,10 \pm 0,81$ & $1,01 \pm 0,54$ & $1,15 \pm 0,62^{A}$ \\
\hline $\mathrm{C} \times 43^{+1+\text { tu }}$ & $8,06 \pm 1,08$ & $9,73 \pm 0,35$ & $-1,58 \pm 0,77$ & $3,30 \pm 1,64$ & $0,37 \pm 0,19^{A}$ \\
\hline Cx43 ${ }^{+/- \text {tu }}$ & $7,88 \pm 1,54$ & ND & ND & ND & ND \\
\hline$q \mathbf{C x} 43^{+1+\text { tu }}$ & $7,21 \pm 1,94$ & $8,00 \pm 0,12$ & $-0,84 \pm 1,75$ & $2,48 \pm 2,43$ & $0,78 \pm 0,76^{A}$ \\
\hline${ }_{q} \mathbf{C} \times 43^{\text {t/-tu }}$ & $7,47 \pm 1,73$ & ND & ND & ND & ND \\
\hline
\end{tabular}

nu = não tratada com uretana; $\mathbf{w u}=$ tratado com uretana; $\mathbf{t u}=$ amostra de tumor (>3mm de diâmetro); NDT = não detectado (onde indicado). 
5.1.6.2.2 Resultados referentes à expressão da Cx32 pela técnica de Real Time PCR

Os resultados referentes à expressão da Cx32 são apresentados nas tabelas 24, 25, 26 e 27. Após a análise estatística, não se observou diferença na expressão da Cx32 entre os camundongos machos de ambos os genótipos comparando-se com a fêmea Cx43 ${ }^{++n u}$ utilizada para a normalização dos resultados (Tabela 24). As fêmeas $\mathrm{C} \times 43^{+/-}$não tratadas com uretana apresentaram aumento significativo na expressão da Cx32 ( $P<0,05)$; evidenciando que a deleção de um dos alelos da $\mathrm{Cx43}$ acarreta num aumento de expressão desta conexina nas fêmeas.

Os resultados dos camundongos tratados com uretana também estão apresentados na tabela 24. Quando os camundongos receberam a uretana, a expressão da Cx32 foi reduzida de maneira mais acentuada nos camundongos machos que nas fêmeas $(P<0,05)$. Nas fêmeas embora ocorra uma redução na expressão esta não foi significativa $(P>0,05)$, quando comparado com os resultados de $\Delta C t$ das fêmeas $C \times 43^{+/+n u}$.

Quando a análise estatística foi realizada dentro de cada grupo (camundongos que receberam ou não as duas injeções de $1,5 \mathrm{~g} / \mathrm{kg}$ de peso vivo de uretana) a diferença de expressão da Cx32 é significativa apenas para as fêmeas $\mathrm{C} \times 43^{+/-}$, mostrando que estas respondem ao tratamento com uretana e também a deleção de um dos alelos da Cx43. Estes resultados estão apresentados na tabela 25. Para os camundongos machos a aplicação da uretana resulta em redução drástica na expressão que, nas fêmeas, embora também ocorra redução da expressão, ela é menor quando se fazem a comparação entre os camundongos $\mathrm{C} \times 43^{+/+}$com os camundongos $\mathrm{C} \times 43^{+/-}$(Tabela 26). 
Quando nós realizamos a análise estatística para se entender o que ocorreu com a expressão da Cx32 entre os genótipos (Tabela 26), o que se observou tanto nos machos quanto nas fêmeas, é que a expressão da Cx32 é afetada significativamente pelo tratamento $(P<0,05)$. Somente nas fêmeas $C \times 43^{+/+}$a diferença observada não foi estaticamente significante $(P>0,05)$. A diferença de expressão entre os camundongos machos tratados com uretana, comparado com os camundongos não tratados com uretana representa cerca de $93 \%$ de redução entre os camundongos $\mathrm{C} \times 43^{+/+}$e de $96 \%$ entre os camundongos $\mathrm{C} \times 43^{+/-}$. Já entre as fêmeas $\mathrm{Cx}_{43} 3^{+-}$a redução foi menor, cerca de $35,71 \%$ na expressão após 25 semanas experimentais. Entre as fêmeas $\mathrm{C} \times 43^{+/+}$a redução de expressão foi menor, cerca de $29 \%$, no entanto, sem significância estatística quando comparado com as fêmeas $\mathrm{Cx}_{4} 3^{+/-}(\mathrm{P}>0,05)$.

Nós consideramos a Cx43 como a principal conexina expressa no tecido pulmonar. Quando se compara a expressão da Cx32 com a Cx43, o que se observa é uma diferença expressiva entre elas. Enquanto os Cts de amplificação da Cx43 foram verificados a partir de 28Cts, a Cx32 é observada a partir de 38Ct (Tabela 24). Estes resultados nos quais comparamos a expressão entre as duas Cxs podem ser encontrados na tabela 27. Esta tabela é exaustiva, mas, faz-se necessário o seu entendimento. Quando os resultados são apresentados após a normalização, o que se observa é quantas vezes um gene tem sua expressão aumentada em relação a um calibrador a escolha do pesquisador. Neste caso, o calibrador escolhido foi a Cx43. Assim, cada resultado de expressão referente a Cx32 foi comparado com seu resultado respectivo de expressão referente a Cx43 (não apenas com as fêmeas $\mathrm{C} \times 43^{+/+n u}$ como é o caso das tabelas anteriores). Como a Cx43 é o calibrador de ecolha, seu resultado normalizado é sempre igual a 1 (lembrando que o $\Delta \Delta C t$ do 
gene de interesse (Cx43) - o $\Delta \Delta C t$ do calibrador (Cx43) é igual a 0 , e que qualquer número elevado a 0 é igual a $\left.1\left(2^{-\Delta \Delta C t}\right)\right)$. O resultado normalizado é um número puro, e 0,5 na alteração da expressão significam 1Ct de diferença em relação ao calibrador. Por exemplo, se a Cx43 tem resultado igual a 1 (julga-se a eficiência da reação de transcrição igual a 100\%), significa 2Cts de expressão. Já os camundongos machos $\mathrm{Cx} 43^{+/+w u}$ apresentam 0,0024 que é igual a 445,76 vezes menor (ou \%) que a expressão da Cx43 (1/0,0024). Assim, com 2Cts a célula encontra-se processando, por exemplo, 446 cópias do RNAm da Cx43 (o que seria possível se determinar apenas com uma curva padrão, o que não é o caso aqui); concomitantemente a célula estará processando 1 cópia do RNAm correspondente a Cx32.

A Cx43 apresenta metade de sua expressão quando um alelo da conexina é deletado. De uma maneira geral, os camundongos machos tratados ou não com uretana, apresentam uma diferença que também é $50 \%$ de expressão em média da Cx32 entre os dois genótipos (49\% entre os camundongos não tratados e $54 \%$ entre os camundongos tratados com uretana) $(P<0,05)$. Entre as fêmeas não tratadas, a diferença na expressão da Cx32 entre os camundongos Cx43 ${ }^{+/-}$e $C \times 43^{+/+}$é de $25 \%$ da Cx43 $(\mathrm{P}<0,05)$. Após o tratamento com a uretana, a diferença entre os genótipos é reduzida para $18 \%$ de expressão em relação a Cx43 $(P<0,05)$. Entre os machos, não se observa redução na diferença de expressão da Cx32 em comparação a Cx43 após o tratamento com uretana. Já entre as fêmeas, embora o tratamento diminua a expressão da Cx32, o que se observa é um aumento na expressão desta conexina culminando com a menor susceptibilidade a uretana. 
Tabela 24 - Tratamento dos resultados de real time PCR onde o target (Cx32) e a referência (GAPDH) foram amplificados em wells separados ${ }^{a}$

\begin{tabular}{|c|c|c|c|c|c|}
\hline Grupos & $\mathrm{C} \times 32 \mathrm{C}_{T}$ & GAPDH $C_{T}$ & $\begin{array}{l}\Delta C_{T} \text { (Média } C_{T} \\
\text { Cx32-Média } \\
C_{T} \text { GAPDH) }\end{array}$ & $\begin{array}{c}\Delta \Delta C_{T} \text { (Média } \\
\Delta \boldsymbol{C}_{T}- \\
\begin{array}{c}\text { Média } \Delta \boldsymbol{C}_{T} \\
\text { fêmea Cx43+/+ nu }\end{array}\end{array}$ & $\begin{array}{c}\text { Expressão da } \\
\text { Cx32 } \\
\text { normalizada } \\
\text { com a fêmea } \\
\mathrm{Cx}^{+1+\text { nu }} \\
\\
\left(2^{-\Delta \Delta C} \mathrm{~T}\right)\end{array}$ \\
\hline $\mathrm{Cx}_{43} 3^{+/+ \text {nu }}$ & $39,02 \pm 0,18$ & $23,61 \pm 0,44$ & $15,41 \pm 0,58^{A}$ & $-0,62 \pm 0,69$ & $1,67 \pm 0,77$ \\
\hline$C \times 43^{+/-n u}$ & $40,24 \pm 0,06$ & $24,45 \pm 0,33$ & $15,79 \pm 0,29^{A}$ & $-0,24 \pm 0,61$ & $1,26 \pm 0,50$ \\
\hline$q \mathbf{C x} 43^{+/+n u}$ & $39,48 \pm 0,27$ & $23,45 \pm 0,09$ & $16,03 \pm 0,33^{A}$ & $0,00 \pm 0,00$ & $1,00 \pm 0,00$ \\
\hline$q \mathbf{C x} 43^{+/-n u}$ & $40,26 \pm 0,26$ & $25,47 \pm 0,26$ & $14,80 \pm 0,07^{B}$ & $-1,23 \pm 0,29$ & $2,38 \pm 0,45$ \\
\hline $\mathrm{C} \times 43^{+1+w u}$ & $41,66 \pm 0,40$ & $22,32 \pm 0,31$ & $19,35 \pm 0,71^{\mathrm{B}}$ & $3,21 \pm 0,75$ & $0,12 \pm 0,06$ \\
\hline $\mathbf{C} \times 43^{+/-w u}$ & $39,84 \pm 0,51$ & $19,55 \pm 0,12$ & $20,28 \pm 0,40^{B}$ & $4,25 \pm 0,34$ & $0,05 \pm 0,01$ \\
\hline${ }_{+} \mathbf{C x} 43^{+/+w u}$ & $35,54 \pm 0,13$ & $18,82 \pm 0,64$ & $16,72 \pm 0,63^{A}$ & $0,70 \pm 0,89$ & $0,71 \pm 0,41$ \\
\hline${ }_{+} \mathbf{C x} 43^{+/-w u}$ & $35,43 \pm 0,31$ & $20,02 \pm 0,21$ & $15,52 \pm 0,37^{A}$ & $-0,61 \pm 0,11$ & $1,53 \pm 0,11$ \\
\hline $\mathrm{Cx} 43^{+/+\mathrm{tu}}$ & ND & $21,66 \pm 0,35$ & ND & ND & ND \\
\hline $\mathrm{C} \times 43^{+/- \text {tu }}$ & ND & $31,65 \pm 0,40$ & ND & ND & ND \\
\hline$\uparrow \mathbf{C x} 43^{+/+ \text {tu }}$ & ND & $22,58 \pm 0,49$ & ND & ND & ND \\
\hline$q \mathbf{C x} 43^{+/- \text {tu }}$ & ND & $33,17 \pm 0,21$ & ND & ND & ND \\
\hline
\end{tabular}

a Usando transcriptase reversa; cDNA foi sintetizado a partir de $500 \mu \mathrm{g}$ de RNA total. Alíquotas de cDNA foram utilizadas como template para as reações de real-time PCR contendo os primers e as probe para a Cx32 ou primers e probe para o GAPDH. Cada reação continha cDNA correspondente a $1 \mathrm{ng}$ de RNA total. Quatro replicatas de cada grupo foram realizadas. nu = não tratada com uretana; $\mathbf{w u}=$ tratado com uretana; $\mathbf{t u}=$ amostra de tumor (>3mm de diâmetro); NDT = não detectado (onde indicado). 
Tabela 25 - Tratamento dos resultados de real time PCR onde o target (Cx32) e a referência (GAPDH) foram amplificados em wells separados ${ }^{a}$. Análise estatística dentro de cada grupo (Com uretana ou sem uretana)

\begin{tabular}{|c|c|c|}
\hline Grupos & $\Delta C_{T} \mathrm{Cx} 32$ & $\begin{array}{l}\text { Expressão da Cx32 normalizada com } \\
\text { a fêmea } \mathrm{C} \times 43^{+/+ \text {nu }} \\
\left(2^{-\Delta \Delta C} \mathrm{~T}\right)\end{array}$ \\
\hline $\mathrm{C} \times 43^{+/+n u}$ & $15,41 \pm 0,58^{B}$ & $1,67 \pm 0,77$ \\
\hline${ }^{\top} \mathrm{C} \times 43^{+/-n u}$ & $15,79 \pm 0,29^{B}$ & $1,26 \pm 0,50$ \\
\hline $9 \mathrm{C} \times 43^{+/+n u}$ & $16,03 \pm 0,33^{B}$ & $1,00 \pm 0,00$ \\
\hline $9 \times 43^{+/-n u}$ & $14,80 \pm 0,07^{A}$ & $2,38 \pm 0,45$ \\
\hline $\mathrm{C} \times 43^{+/+w u}$ & $19,35 \pm 0,71^{A}$ & $0,12 \pm 0,06$ \\
\hline $\mathrm{C} \times 43^{+-/ w u}$ & $20,28 \pm 0,40^{A}$ & $0,05 \pm 0,01$ \\
\hline $9 \mathrm{C} \times 43^{+/+w u}$ & $16,72 \pm 0,63^{\mathrm{B}}$ & $0,71 \pm 0,41$ \\
\hline $9 \mathrm{Cx} 43^{+/-w u}$ & $15,52 \pm 0,37^{\mathrm{C}}$ & $1,53 \pm 0,11$ \\
\hline
\end{tabular}

Resultados seguidos de caracteres iguais não diferem entre si. nu = não tratada com uretana; $\mathbf{w u}=$ tratado com uretana; tu = amostra de tumor (>3mm de diâmetro); NDT = não detectado (onde indicado). 
Tabela 26 - Tratamento dos resultados de real time PCR onde o target (Cx32) e a referência (GAPDH) foram amplificados em wells separados ${ }^{a}$. Análise estatística comparando os genótipos dentro dos diferentes tratamentos (Com uretana ou sem uretana)

\begin{tabular}{|c|c|c|c|}
\hline Grupos & $\Delta C_{T} \mathrm{Cx} 32$ & $\begin{array}{l}\text { Expressão da } C \times 32 \text { normalizada } \\
\text { com a fêmea } C \times 43^{+/+n u} \\
\left(2^{-\Delta \Delta C} \mathrm{~T}\right)\end{array}$ & $\begin{array}{l}\text { Diferença de } \\
\text { expressão em } \\
\text { relação ao indivíduo } \\
\text { não tratado }\end{array}$ \\
\hline $\mathrm{C} C \times 43^{+/+n u}$ & $15,41 \pm 0,58^{a}$ & $1,67 \pm 0,77$ & 13,92 \\
\hline${ }^{7} \mathrm{C} \times 43^{+/+w u}$ & $19,35 \pm 0,71^{A}$ & $0,12 \pm 0,06$ & \\
\hline${ }^{7} \mathrm{C} \times 43^{+/-n u}$ & $15,79 \pm 0,29^{a}$ & $1,26 \pm 0,50$ & 25,20 \\
\hline $\mathrm{C} C \times 43^{+/-w u}$ & $20,28 \pm 0,40^{A}$ & $0,05 \pm 0,01$ & \\
\hline $9 \mathrm{Cx} 43^{+/+n u}$ & $16,03 \pm 0,33^{A}$ & $1,00 \pm 0,00$ & 1,41 \\
\hline$+\mathrm{Cx} 43^{+/+w u}$ & $16,72 \pm 0,63^{A}$ & $0,71 \pm 0,41$ & \\
\hline$+\mathrm{Cx} 43^{+/-n u}$ & $14,80 \pm 0,07^{a}$ & $2,38 \pm 0,45$ & 1,56 \\
\hline $9 \mathrm{C} \times 43^{+/-w u}$ & $15,52 \pm 0,37^{A}$ & $1,53 \pm 0,11$ & \\
\hline
\end{tabular}

Resultados seguidos de caracteres iguais não diferem entre si. nu = não tratada com uretana; wu = tratado com uretana; tu = amostra de tumor (>3mm de diâmetro); NDT = não detectado (onde indicado). 
Tabela 27 - Tratamento dos resultados de real time PCR onde o $\Delta$ Ct do target (Cx32) foi comparado ao $\Delta \mathrm{Ct}$ da $\mathrm{Cx} 43$ no respectivo tratamento

\begin{tabular}{|c|c|c|c|c|c|}
\hline Grupos & $\Delta C_{T} \mathrm{Cx} 32$ & $\Delta C_{T} \mathrm{Cx43}$ & 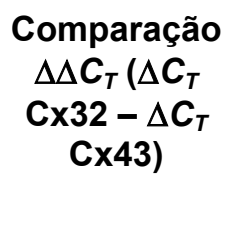 & $\begin{array}{c}\text { Expressão da } \\
\text { Cx32 } \\
\text { normalizada com } \\
\text { a Cx43 }\left(2^{-\Delta \Delta C} \mathrm{~T}\right)\end{array}$ & $\begin{array}{c}\text { Expressão } \\
\text { normalizada da } \\
\text { Cx43 (1) / } \\
\text { Expressão } \\
\text { normalizada da } \\
\text { Cx32 }\end{array}$ \\
\hline $\mathrm{C} \times 4^{+/+n u}$ & $15,41 \pm 0,58$ & $6,65 \pm 0,23$ & $8,77 \pm 0,36$ & $0,0024 \pm 0,0005$ & $445,76 \pm 117,72^{A}$ \\
\hline $\mathrm{C} \times 43^{+/-n u}$ & $15,79 \pm 0,29$ & $8,05 \pm 0,66$ & $7,74 \pm 0,37$ & $0,0048 \pm 0,0012$ & $219,20 \pm 57,08^{\mathrm{B}}$ \\
\hline$\bigcirc \mathbf{C x} 43^{+++n u}$ & $16,03 \pm 0,33$ & $6,92 \pm 0,17$ & $9,11 \pm 0,19$ & $0,0018 \pm 0,0002$ & $554,96 \pm 68,22^{A}$ \\
\hline$\rho \mathbf{C x} 43^{+/-n u}$ & $14,80 \pm 0,07$ & $7,66 \pm 0,27$ & $7,14 \pm 0,20$ & $0,0072 \pm 0,0010$ & $141,80 \pm 18,77^{B}$ \\
\hline $\mathrm{C} \times 43^{+++w u}$ & $19,35 \pm 0,71$ & $6,07 \pm 0,17$ & $13,28 \pm 0,80$ & $0,000112 \pm 0,000059$ & $11143,03 \pm 5739,91^{A}$ \\
\hline $\mathbf{C x} 43^{+1-w u}$ & $20,28 \pm 0,40$ & $7,72 \pm 0,32$ & $12,56 \pm 0,19$ & $0,000166 \pm 0,000023$ & $6088,10 \pm 772,65^{\mathrm{B}}$ \\
\hline${ }_{+} \mathbf{C x} \mathbf{4 3}^{+/+w u}$ & $16,72 \pm 0,63$ & $6,15 \pm 0,58$ & $10,58 \pm 0,76$ & $0,000720 \pm 0,000337$ & $1698,29 \pm 917,53^{A}$ \\
\hline$\uparrow \mathbf{C x} 43^{+/-w u}$ & $15,52 \pm 0,37$ & $7,41 \pm 0,63$ & $8,01 \pm 0,95$ & $0,004485 \pm 0,002556$ & $306,03 \pm 219,42^{\mathrm{B}}$ \\
\hline${ }^{2} \mathrm{C} \times 43^{\text {t+tu }}$ & ND & $9,73 \pm 0,35$ & ND & ND & ND \\
\hline $\mathbf{C} \times 43^{+/ \text {tu }}$ & ND & ND & ND & ND & ND \\
\hline$\rho \mathbf{C x} 43^{+1+\text { tu }}$ & ND & $8,00 \pm 0,12$ & ND & ND & ND \\
\hline$q \mathbf{C x} 43^{+/- \text {tu }}$ & ND & ND & ND & ND & ND \\
\hline
\end{tabular}

nu = não tratada com uretana; $\mathbf{w u}=$ tratado com uretana; $\mathbf{t u}=$ amostra de tumor (>3mm de diâmetro); NDT = não detectado (onde indicado). 
5.1.6.2.3 Resultados referentes à expressão da Cx46 pela técnica de Real Time PCR

Os resultados referentes à expressão da Cx46 no tecido pulmonar e nos adenomas são apresentados na tabela 28. As análises estatísticas correspondentes são mostradas nas tabelas 29, 30 e 31.

Os camundongos machos $\mathrm{C} \times 43^{+/+}$não tratados com uretana não apresentam diferença de expressão em comparação as fêmeas $C \times 43^{+/+n u}(P>0,05)$. No entanto, a deleção de um dos alelos da Cx43 acarretou um aumento na expressão da Cx46 de forma idêntica entre os camundongos machos e fêmeas $(P<0,05)$. O tratamento aos 15 e 17 dias de idade com uretana reduziu significativamente a expressão da Cx46 em todos os grupos $(P<0,05)$ quando comparado com o calibrador.

Nos adenomas a Cx46 foi detectada nos adenomas de todos os camundongos estudados. As maiores alterações de expressão foram verificadas nos camundongos machos $\mathrm{Cx}_{4} 3^{+/}(P<0,05)$ e nas fêmeas $\mathrm{Cx} 43^{+/+}(P>0,05)$. A expressão verificada entre os camundongos machos $C \times 43^{+/+}$e as fêmeas $C \times 43^{+/+}$não difere significativamente do calibrador $(P>0,05)$.

$\mathrm{Na}$ tabela 29 é apresentada a análise estatística realizada dentro de cada grupo experimental. Na deficiência de um dos alelos da Cx43 ocorre um aumento significativo de expressão da Cx46 nos camundongos $\mathrm{Cx}_{4} 3^{+/}(\mathrm{P}<0,05)$. Após o tratamento com uretana, ocorre uma redução drástica de expressão da Cx46. Os camundongos $\mathrm{Cx} 43^{+/-}$machos, no entanto, apresentam níveis de expressão relativamente superior aos demais grupos. 
Comparando os diferentes genótipos após a aplicação da uretana (Tabela 30) ocorreu uma tendência de queda na expressão em todos os grupos experimentais $(P<0,05)$

$\mathrm{Na}$ tabela 31 são apresentados os resultados de expressão da Cx46 comparado com a expressão da Cx43. O que se observa é que a deleção de um dos alelos da Cx43 reduz a diferença quando se compara a expressão entre as conexinas $\left(6,89\right.$ e 8,18 para os camundongos $\mathrm{C} \times 43^{+/-}$machos e fêmeas respectivamente) $(\mathrm{P}<0,05)$. Entre os camundongos $\mathrm{Cx} 43^{+/+}$o nível de expressão comparado a da Cx43 é praticamente idêntica entre os grupos $(P>0,05)$. A diferença de expressão entre a Cx46 e a Cx43 é evidente, mas, é menos acentuada entre os camundongos $\mathrm{C} \times 43^{+/-}$devido à ausência de um dos alelos da Cx43. O nível de expressão entre as fêmeas é maior que entre os machos, sendo a diferença entre os genótipos de 11,96 e de 1,47, para machos e fêmeas respectivamente.

Nos adenomas, não se verificou expressão da Cx43 nos camundongos $\mathrm{C} \times 43^{+/-}$. Porém, nos camundongos $\mathrm{C} \times 43^{+/+}$, que expressão $\mathrm{C} \times 43$ nos adenomas, o que se verificou foi a presença da Cx46, mas sem diferença entre os grupos comparados. 
Tabela 28 - Tratamento dos resultados de real time PCR onde o target $(C x 46)$ e a referência (GAPDH) foram amplificados em wells separados ${ }^{a}$

\begin{tabular}{|c|c|c|c|c|c|}
\hline Grupos & $\mathrm{Cx}_{46} C_{T}$ & GAPDH $C_{T}$ & $\begin{array}{l}\Delta C_{T} \text { (Média } \\
C_{T} \text { Cx46- } \\
\text { Média } C_{T} \\
\text { GAPDH) }\end{array}$ & $\begin{array}{c}\Delta \Delta C_{T} \text { (Média } \Delta C_{T} \\
- \\
\underset{C \times 43+/+}{M e ́ d i a ~} C_{T}^{\text {fêmea }}\end{array}$ & $\begin{array}{l}\text { Expressão da Cx46 } \\
\text { normalizada com a } \\
\text { fêmea } C \times 43^{+/+n u} \\
\left(2^{-\Delta \Delta C}\right)\end{array}$ \\
\hline $\mathrm{C} \times 43^{+/+n u}$ & $36,21 \pm 0,20$ & $25,12 \pm 0,09$ & $11,10 \pm 0,11^{\mathrm{A}}$ & $-0,43 \pm 0,43$ & $1,39 \pm 0,42$ \\
\hline${ }^{\top} \mathrm{C} \times 43^{+/-\mathrm{nu}}$ & $34,52 \pm 0,73$ & $23,75 \pm 0,81$ & $10,77 \pm 0,19^{B}$ & $-0,76 \pm 0,51$ & $1,77 \pm 0,68$ \\
\hline$q \mathbf{C} \times \mathbf{4 3} 3^{+/+n u}$ & $34,61 \pm 0,49$ & $23,08 \pm 0,42$ & $11,53 \pm 0,33^{A}$ & $0,00 \pm 0,00$ & $1,00 \pm 0,00$ \\
\hline $9 \mathbf{C x 4 3 ^ { + / - n u }}$ & $40,12 \pm 0,36$ & $29,46 \pm 0,32$ & $10,66 \pm 0,22^{\mathrm{B}}$ & $-0,87 \pm 0,38$ & $1,88 \pm 0,50$ \\
\hline${ }^{7} \mathrm{C} \times 43^{+/+w u}$ & $38,75 \pm 0,45$ & $22,09 \pm 0,37$ & $16,66 \pm 0,36^{\mathrm{B}}$ & $4,95 \pm 0,70$ & $0,03 \pm 0,01$ \\
\hline${ }^{\lambda} \mathrm{C} \times 43^{+/-w u}$ & $35,31 \pm 0,45$ & $20,56 \pm 0,44$ & $14,76 \pm 0,20^{B}$ & $3,23 \pm 0,21$ & $0,11 \pm 0,02$ \\
\hline${ }_{+} \mathbf{C x 4 3 ^ { + / + w u }}$ & $38,82 \pm 1,00$ & $23,42 \pm$ & $15,40 \pm 0,87^{B}$ & $3,87 \pm 0,61$ & $0,07 \pm 0,03$ \\
\hline$+\mathbf{C x 4 3 ^ { + / - w u }}$ & $38,41 \pm 0,28$ & $22,14 \pm 0,06$ & $16,27 \pm 0,28^{B}$ & $4,74 \pm 0,31$ & $0,04 \pm 0,01$ \\
\hline${ }^{\top} \mathrm{C} \times 43^{+/+\mathrm{tu}}$ & $35,52 \pm 2,24$ & $23,98 \pm 2,57$ & $11,54 \pm 0,46^{A}$ & $0,01 \pm 0,65$ & $1,07 \pm 0,43$ \\
\hline$J^{\top} \mathrm{C} \times 43^{+/-\mathrm{tu}}$ & $38,97 \pm 0,72$ & $31,25 \pm 0,25$ & $7,72 \pm 0,88^{B}$ & $-3,81 \pm 0,83$ & $15,68 \pm 7,88$ \\
\hline$+\mathbf{C x 4 3 ^ { + / + t u }}$ & $40,22 \pm 2,05$ & $28,77 \pm 7,58$ & $11,44 \pm 5,62^{A}$ & $-0,09 \pm 5,72$ & $16,88 \pm 20,73$ \\
\hline$q \mathbf{C x 4 3 ^ { + / - t u }}$ & $48,15 \pm 0,83$ & $32,90 \pm 0,36$ & $15,25 \pm 0,54^{A}$ & $3,72 \pm 0,48$ & $0,08 \pm 0,02$ \\
\hline
\end{tabular}

a Usando transcriptase reversa; cDNA foi sintetizado a partir de $500 \mu \mathrm{g}$ de RNA total. Alíquotas de cDNA foram utilizadas como template para as reações de real-time PCR contendo os primers e as probe para a Cx46 ou primers e probe para o GAPDH. Cada reação continha cDNA correspondente a $1 \mathrm{ng}$ de RNA total. Quatro replicatas de cada grupo foram realizadas. nu = não tratada com uretana; $\mathbf{w u}=$ tratado com uretana; $\mathbf{t u}=$ amostra de tumor (>3mm de diâmetro); NDT = não detectado (onde indicado). 
Tabela 29 - Tratamento dos resultados de real time PCR onde o target (Cx46) e a referência (GAPDH) foram amplificados em wells separados ${ }^{a}$. Análise estatística dentro de cada grupo (Com uretana ou sem uretana)

\begin{tabular}{|c|c|c|}
\hline Grupos & $\Delta C_{T} \mathrm{Cx} 46$ & $\begin{array}{l}\text { Expressão da Cx46 normalizada com } \\
\text { a fêmea } \mathrm{C} \times 43^{+/+n u} \\
\left(2^{-\Delta \Delta C} \mathrm{~T}\right)\end{array}$ \\
\hline $\mathbf{C} \times 43^{+/+n u}$ & $11,10 \pm 0,11^{A}$ & $1,39 \pm 0,42$ \\
\hline${ }^{\lambda} \mathrm{C} \times 43^{+/-\mathrm{nu}}$ & $10,77 \pm 0,19^{B}$ & $1,77 \pm 0,68$ \\
\hline${ }_{+} \mathbf{C x} 43^{+/+n u}$ & $11,53 \pm 0,33^{A}$ & $1,00 \pm 0,00$ \\
\hline$q \mathbf{C x 4 3 ^ { + / - n u }}$ & $10,66 \pm 0,22^{B}$ & $1,88 \pm 0,50$ \\
\hline Cx43 $3^{+/+w u}$ & $16,66 \pm 0,36^{A}$ & $0,03 \pm 0,01$ \\
\hline $\mathrm{C} \times 43^{+-/ w u}$ & $14,76 \pm 0,20^{B}$ & $0,11 \pm 0,02$ \\
\hline$+\mathbf{C x 4 3 ^ { + / + w u }}$ & $15,40 \pm 0,87^{A}$ & $0,07 \pm 0,03$ \\
\hline$q \mathbf{C x 4 3 ^ { + / - w u }}$ & $16,27 \pm 0,28^{A}$ & $0,04 \pm 0,01$ \\
\hline
\end{tabular}

Resultados seguidos de caracteres iguais não diferem entre si. nu = não tratada com uretana; $\mathbf{w u}=$ tratado com uretana; tu = amostra de tumor (>3mm de diâmetro); NDT = não detectado (onde indicado). 
Tabela 30 - Tratamento dos resultados de real time PCR onde o target (Cx46) e a referência (GAPDH) foram amplificados em wells separados ${ }^{a}$. Análise estatística comparando os genótipos dentro dos diferentes tratamentos (Com uretana ou sem uretana)

\begin{tabular}{|c|c|c|c|}
\hline Grupos & ${ }_{\Delta} C_{T} \mathrm{Cx} 46$ & $\begin{array}{l}\text { Expressão da Cx46 normalizada } \\
\text { com a fêmea } C \times 43^{+/+n u} \\
\left(2^{-\Delta \Delta C} \mathrm{~T}\right)\end{array}$ & $\begin{array}{l}\text { Diferença de } \\
\text { expressão em } \\
\text { relação ao indivíduo } \\
\text { não tratado }\end{array}$ \\
\hline $\mathrm{C} \times 43^{+/+n u}$ & $11,10 \pm 0,11^{B}$ & $1,39 \pm 0,42$ & 46,33 \\
\hline $\mathbf{C} \times 43^{+/+w u}$ & $16,66 \pm 0,36^{A}$ & $0,03 \pm 0,01$ & \\
\hline$\overbrace{C} \times 43^{+/-n u}$ & $10,77 \pm 0,19^{B}$ & $1,77 \pm 0,68$ & 16,09 \\
\hline CX43 ${ }^{+/-w u}$ & $14,76 \pm 0,20^{A}$ & $0,11 \pm 0,02$ & \\
\hline${ }_{+} \mathbf{C} \times 43^{+/+n u}$ & $11,53 \pm 0,33^{B}$ & $1,00 \pm 0,00$ & 14,29 \\
\hline${ }_{+} \mathbf{C x} 43^{+/+w u}$ & $15,40 \pm 0,87^{A}$ & $0,07 \pm 0,03$ & \\
\hline$+\mathbf{C x 4 3 ^ { + / - n u }}$ & $10,66 \pm 0,22^{B}$ & $1,88 \pm 0,50$ & 47,00 \\
\hline${ }_{+} \mathbf{C x 4 3 ^ { + / - w u }}$ & $16,27 \pm 0,28^{A}$ & $0,04 \pm 0,01$ & \\
\hline
\end{tabular}

Resultados seguidos de caracteres iguais não diferem entre si. nu = não tratada com uretana; wu = tratado com uretana; tu = amostra de tumor (>3mm de diâmetro); NDT = não detectado (onde indicado). 
Tabela 31 - Tratamento dos resultados de real time PCR onde o $\Delta$ Ct do target (Cx46) foi comparado o $\Delta \mathrm{Ct}$ da $\mathrm{Cx} 43$ no respectivo tratamento, neste caso o resultado de expressão normalizado ao da Cx43 foi considerado igual a 1

\begin{tabular}{|c|c|c|c|c|c|}
\hline Grupos & $\Delta C_{T} \mathrm{Cx} 46$ & $\Delta C_{T} \mathrm{Cx43}$ & $\begin{array}{c}\text { Comparação } \Delta \Delta C_{T} \\
\left(\Delta C_{T} \text { Cx46- }-\Delta C_{T}\right. \\
\text { Cx43) }\end{array}$ & $\begin{array}{l}\text { Expressão da Cx46 } \\
\text { normalizada com a } \\
\quad \text { Cx43 }\left(2^{-\Delta \Lambda C} \mathrm{~T}\right)\end{array}$ & $\begin{array}{c}\text { Expressão } \\
\text { normalizada da } \\
\text { Cx43 (1) / } \\
\text { Expressão } \\
\text { normalizada da } \\
\text { Cx46 }\end{array}$ \\
\hline${ }^{7} \mathrm{C} \times 43^{+/+n u}$ & $11,10 \pm 0,11$ & $6,65 \pm 0,23$ & $4,45 \pm 0,20$ & $0,05 \pm 0,006$ & $22,05 \pm 2,99^{A}$ \\
\hline${ }^{7} \mathrm{C} \times 43^{+/- \text {nu }}$ & $10,77 \pm 0,19$ & $8,05 \pm 0,66$ & $2,72 \pm 0,49$ & $0,16 \pm 0,053$ & $6,89 \pm 2,28^{B}$ \\
\hline$+\mathbf{C x 4 3 ^ { + / + n u }}$ & $11,53 \pm 0,33$ & $6,92 \pm 0,17$ & $4,61 \pm 0,16$ & $0,04 \pm 0,004$ & $24,49 \pm 2,78^{A}$ \\
\hline$+\mathbf{C x 4 3 ^ { + / - n u }}$ & $10,66 \pm 0,22$ & $7,66 \pm 0,27$ & $3,00 \pm 0,36$ & $0,13 \pm 0,032$ & $8,18 \pm 1,95^{\mathrm{B}}$ \\
\hline Cx43 ${ }^{+/+w u}$ & $16,66 \pm 0,36$ & $6,07 \pm 0,17$ & $10,59 \pm 0,44$ & $0,00067 \pm 0,00021$ & $1597,3 \pm 462,48^{A}$ \\
\hline $\mathrm{Cx}^{7} 3^{\text {+/-wu }}$ & $14,76 \pm 0,20$ & $7,72 \pm 0,32$ & $7,04 \pm 0,29$ & $0,0077 \pm 0,00154$ & $133,6 \pm 26,22^{B}$ \\
\hline$+\mathbf{C x 4 3 ^ { + / + w u }}$ & $15,40 \pm 0,87$ & $6,15 \pm 0,58$ & $9,26 \pm 1,08$ & $0,002 \pm 0,0014$ & $750,20 \pm 554,95^{A}$ \\
\hline$+\mathbf{C x 4 3 ^ { + / - w u }}$ & $16,27 \pm 0,28$ & $7,41 \pm 0,63$ & $8,86 \pm 0,67$ & $0,00231 \pm 0,0009$ & $508,8 \pm 269,53^{B}$ \\
\hline $\mathbf{C} \times 43^{+/+ \text {tu }}$ & $11,54 \pm 0,46$ & $9,73 \pm 0,35$ & $1,81 \pm 0,79$ & $0,317 \pm 0,159$ & $3,08 \pm 0,11^{A}$ \\
\hline${ }^{7} \mathbf{C} \times 43^{+/- \text {tu }}$ & $7,72 \pm 0,88$ & ND & ND & ND & ND \\
\hline$+\mathbf{C x 4 3 ^ { + / + t u }}$ & $11,44 \pm 5,62$ & $8,00 \pm 0,12$ & $3,44 \pm 5,58$ & $1,30 \pm 1,49$ & $0,74 \pm 1,51^{\mathrm{A}}$ \\
\hline$+\mathbf{C x 4 3 ^ { + / - t u }}$ & $15,25 \pm 0,54$ & ND & ND & ND & ND \\
\hline
\end{tabular}

nu = não tratada com uretana; $\mathbf{w u}=$ tratado com uretana; $\mathbf{t u}=$ amostra de tumor (>3mm de diâmetro); NDT = não detectado (onde indicado). 


\subsubsection{Immunoistoquímica para a Cx43 nos tecidos pulmonares tratados ou não com uretana}

A imunomarcação da Cx43 pode ser observada nas figuras 29 e 30. Pode-se observar que tanto nas fêmeas quanto nos machos $\mathrm{C} \times 43^{+/-}$ocorreu uma diminuição na intensidade de marcação da Cx43. A marcação não ficou restrita a apenas algumas regiões. O tratamento com uretana parece não ter interferido no seu direcionamento para a membrana celular. Os dados de imunoistoquímica confirmam os resultados observados no Western blot e no Real Time PCR.

Nas lesões sólidas, mistas ou papilíferas, nota-se uma redução da marcação quando comparada com o tecido normal. A redução é mais notável ainda nos preparados dos camundongos $\mathrm{C} \times 43^{+/-}$(Figura 30).

Nenhuma diferença entre machos e fêmeas, tratados ou não tratados, normal ou tumoral foi observado (Figura 29 e 30). A única diferença diz respeito ao genótipo dos camundongos. 

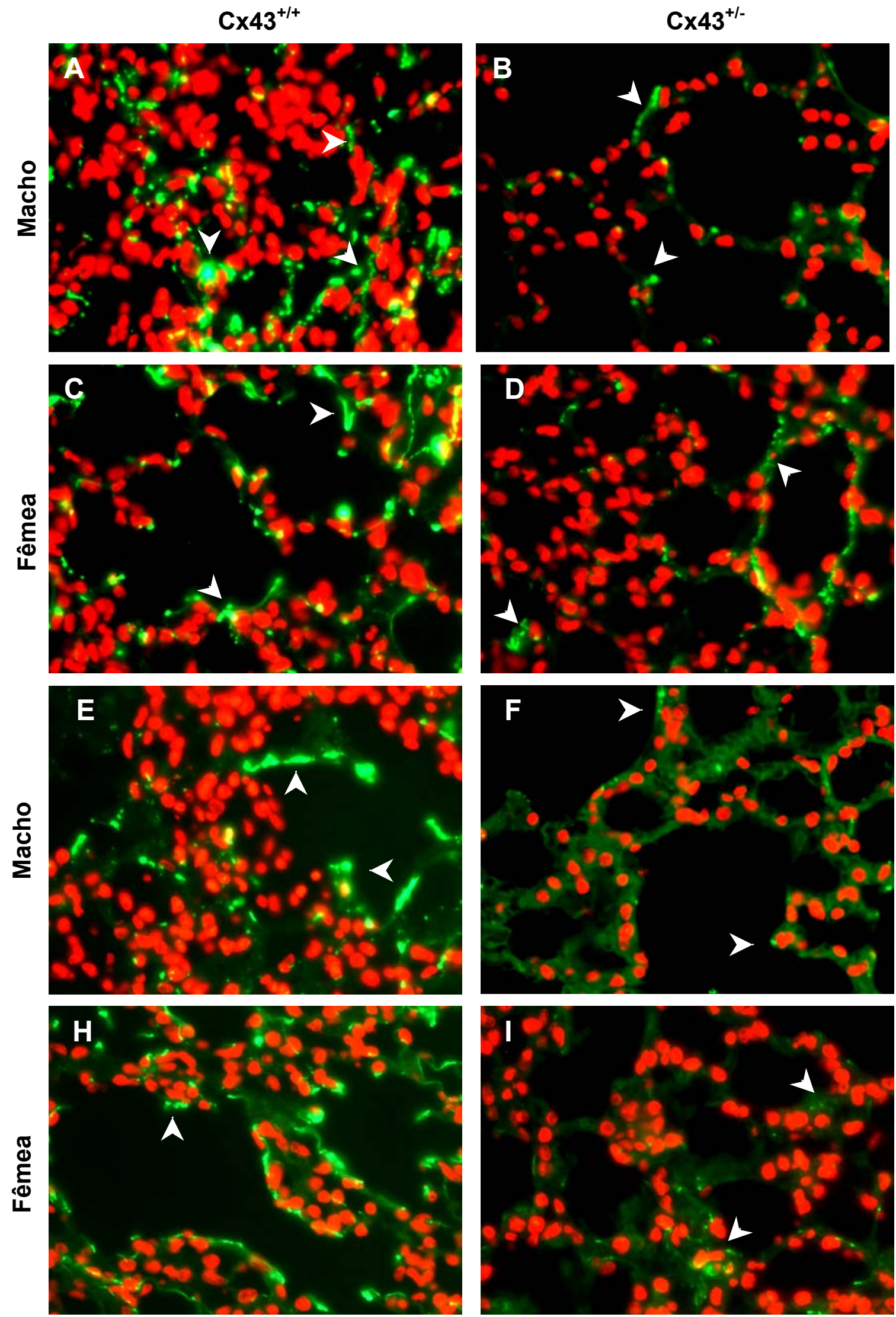

Figura 29 - Imunomarcação da Cx43 nos tecidos pulmonares de camundongos tratados ou não com uretana. A. B. C. D. Camundongos não submetidos ao tratamento com uretana. E. F. H. I. Camundongos submetidos ao tratamento com uretana. $\mathrm{O}$ controle negativo da reação pode ser observado na figura $32 \mathrm{H}$. A setas apontam para a $\mathrm{C} \times 43$ marcada. Imagem obtida na objetiva de $40 \mathrm{X}$ 


\section{Cx43 ${ }^{+/+}$}
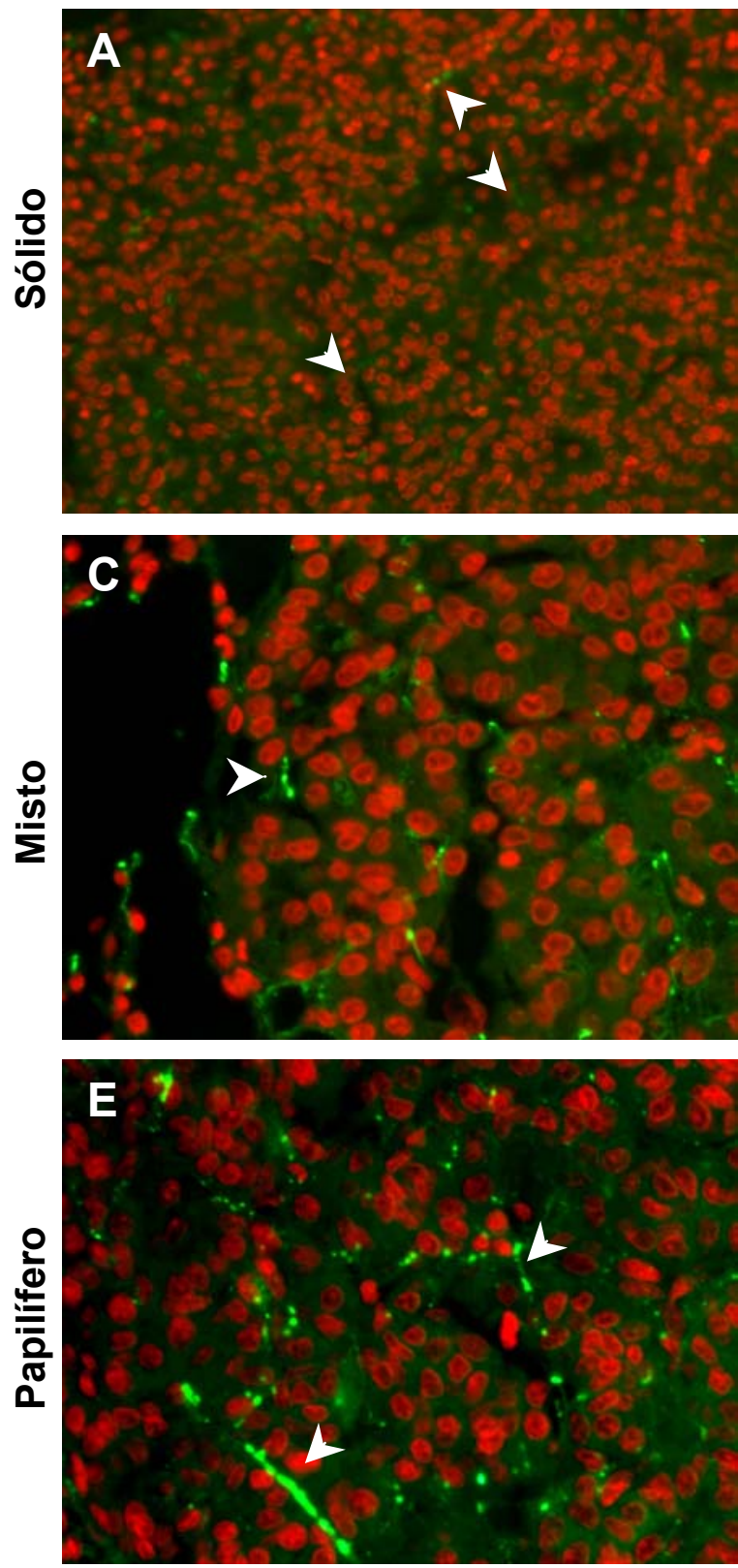

$\mathrm{Cx} 43^{+/-}$
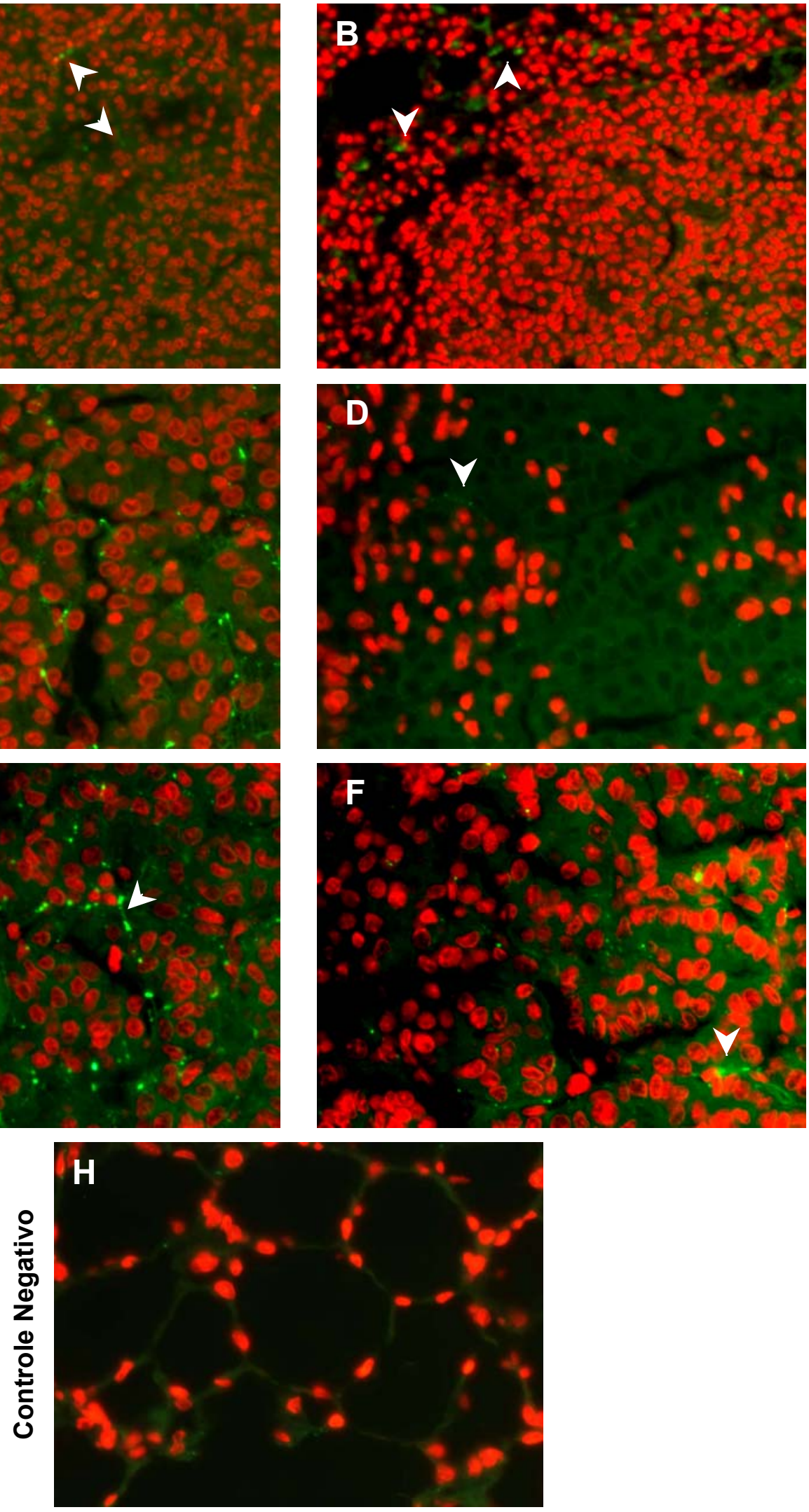

Figura 30 - Imunomarcação para a Cx43 nos tumores induzidos quimicamente pela uretana. A. C. E. Tumores observados em camundongos $\mathrm{C} \times 43^{+/+}$. B. D. F. Tumores observados em camundongos $\mathrm{C} \times 43^{+/}$. Notar a diferença na intensidade de marcação quando comparado com os camundongos $\mathrm{C} \times 43^{+/+}$. Como não foram observados diferenças nas marcações entre machos e fêmeas, são apresentados dados mistos de machos e fêmeas não identificados, separados apenas pelo genótipo. Imagem obtida na objetiva de 40X 


\subsubsection{Imunomarcação da Cx26 no tecido pulmonar submetido ou não ao tratamento com uretana e nos respectivos adenomas}

As figuras de imunomarcação correspondentes a Cx26 podem ser encontradas nas figuras 31 e 32 para os camundongos machos e fêmeas, e figuras 33 e 35 para os adenomas dos camundongos machos e fêmeas, respectivamente.

A imunomarcação da Cx26 é restrita a alguns grupos de células, notadamente no canto dos alvéolos (onde, segundo a literatura, são encontrados os pneumócitos do tipo II). Este tipo de marcação é diferente daquela da Cx43, que está amplamente distribuída por toda a região alveolar. Entre os camundongos machos $\mathrm{C} \times 43^{+/-}$não tratados com uretana (Figura 31 C), a marcação é mais intensa quando comparado com os camundongos $\mathrm{Cx}_{43^{+/+}}$não tratados com uretana (Figura $31 \mathrm{D}$ ). Aparentemente, a deleção de um dos alelos da Cx43 influenciou positivamente a expressão da Cx26.

Quando tratados com uretana e avaliados com a técnica da imunoistoquímica, o que se observa é uma dramática redução dos níveis desta conexina no tecido pulmonar (Figura 31 A e B). No entanto, a marcação ainda pode ser observada e é mais intensa entre os camundongos machos $\mathrm{C} \times 43^{+/-}$quando comparados com os respectivos camundongos $\mathrm{C} \times 43^{+/+}$(Figura $31 \mathrm{~A}$ e B).

Contudo, a marcação que é evidente quando comparado com o controle negativo (Figura 31 E), não nos permite afirmar com clareza dos fatos se esta é uma marcação que corresponde a presença da Cx na membrana dos pneumócitos ou que ela está restrita ao citoplasma destas células.

O padrão de marcação da Cx26 registrado para os camundongos fêmeas é apresentado na figura 32. O mesmo padrão de marcação pode ser identificado, ou 
seja, algumas células são identificadas pelo anticorpo policlonal contra a Cx26 (Figura 32 C e D), que deixam de identificá-la com a mesma afinidade nos pneumócitos dos camundongos que foram tratados com a uretana aos 15 e 17 dias de idade (Figura $32 \mathrm{~A}$ e B).

Nos adenomas pulmonares (Figuras 33 e 35), principalmente nas fêmeas, verificou-se a presença de intensa marcação. O que pode ser comentado a respeito, é que embora exista a presença de Cx26 nos adenomas, a marcação é restrita a periferia dos adenomas (Figuras $33 \mathrm{E}$ e F) e na figura 35. Com este padrão de marcação, podemos afirmar com certeza que, embora presente nos adenomas, a Cx26 não está comunicando o citoplasma de uma célula com a outra no adenoma; o contrário seria desejável. 

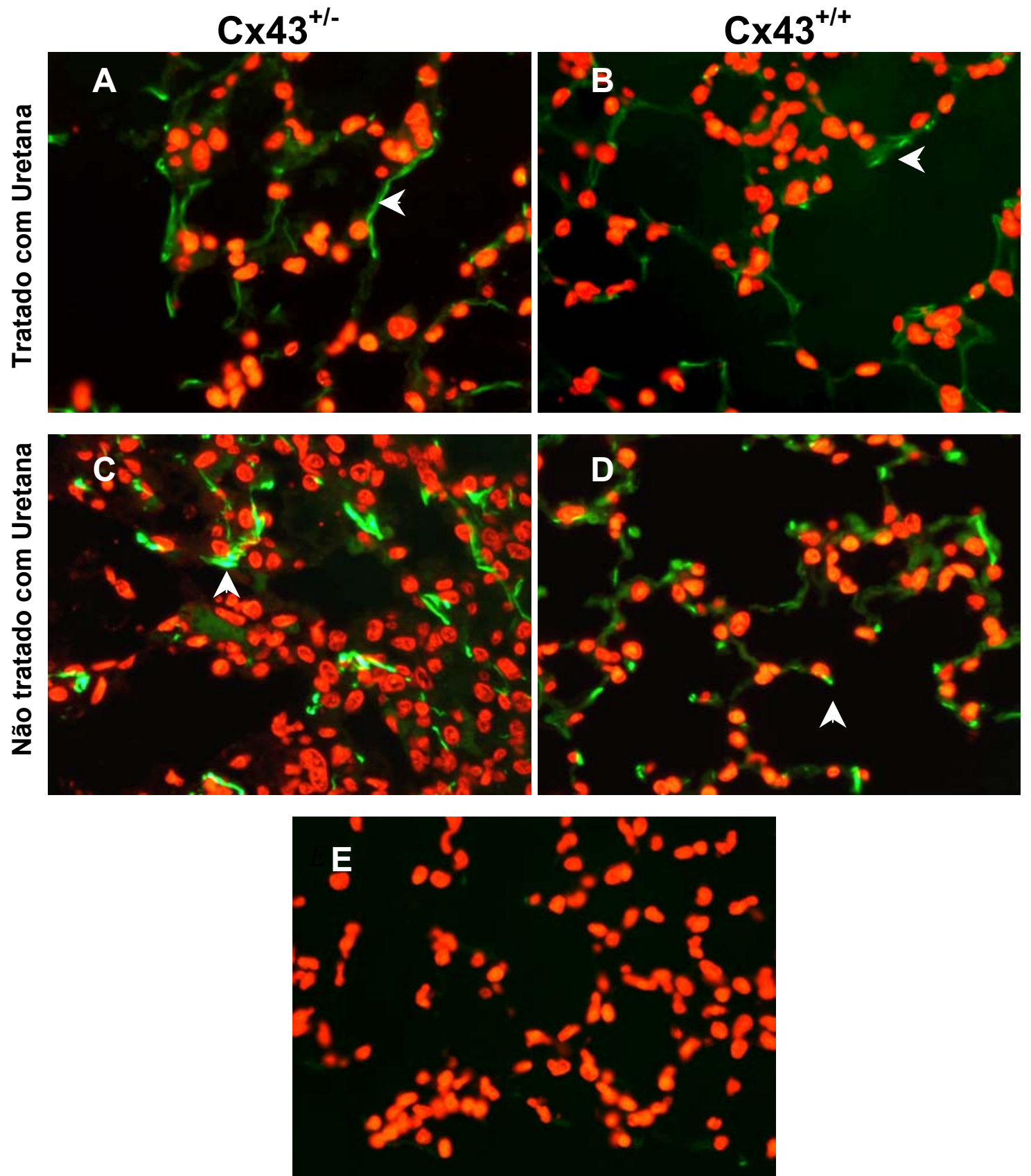

Figura 31 - Imunomarcação da Cx26 em pulmões de camundongos machos após 25 semanas de tratamento com uretana. Os camundongos foram sacrificados 25 semanas após a injeção intraperitoneal de uretana $(1,5 \mathrm{~g} / \mathrm{Kg})$. A.C. Área representativa dos pulmões correspondente aos camundongos $\mathrm{Cx}_{43} 3^{+/}$, tratados ou não com uretana, respectivamente. B.D. Área representativa dos pulmões correspondentes aos camundongos $\mathrm{C} \times 43^{+/+}$, tratados ou não com uretana, respectivamente. E. Controle negativo da reação. A seta aponta para a marcação correspondente à Cx26. $\mathrm{O}$ anticorpo policlonal contra a Cx26 foi diluído na proporção de 1:200. Os núcleos foram corados com iodeto de propídeo (1:1000). Aumento corresponde a objetiva de 40X 
$C \times 43^{+/-}$
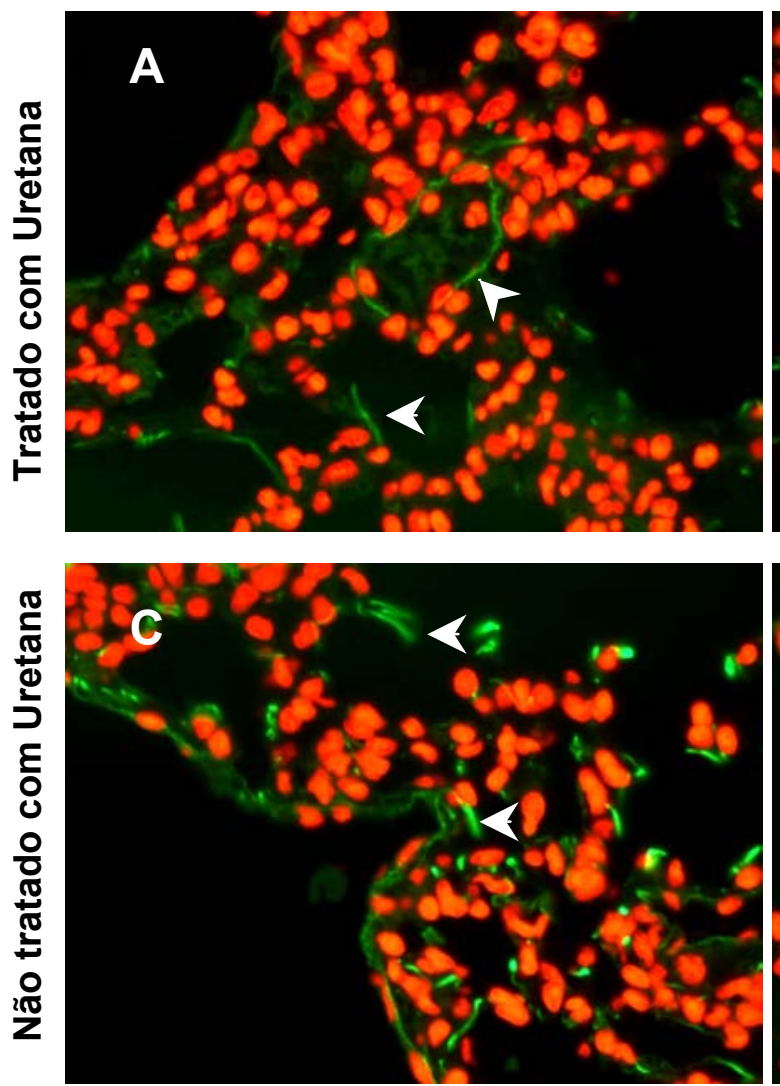

\section{$\mathrm{Cx} 43^{+/+}$}
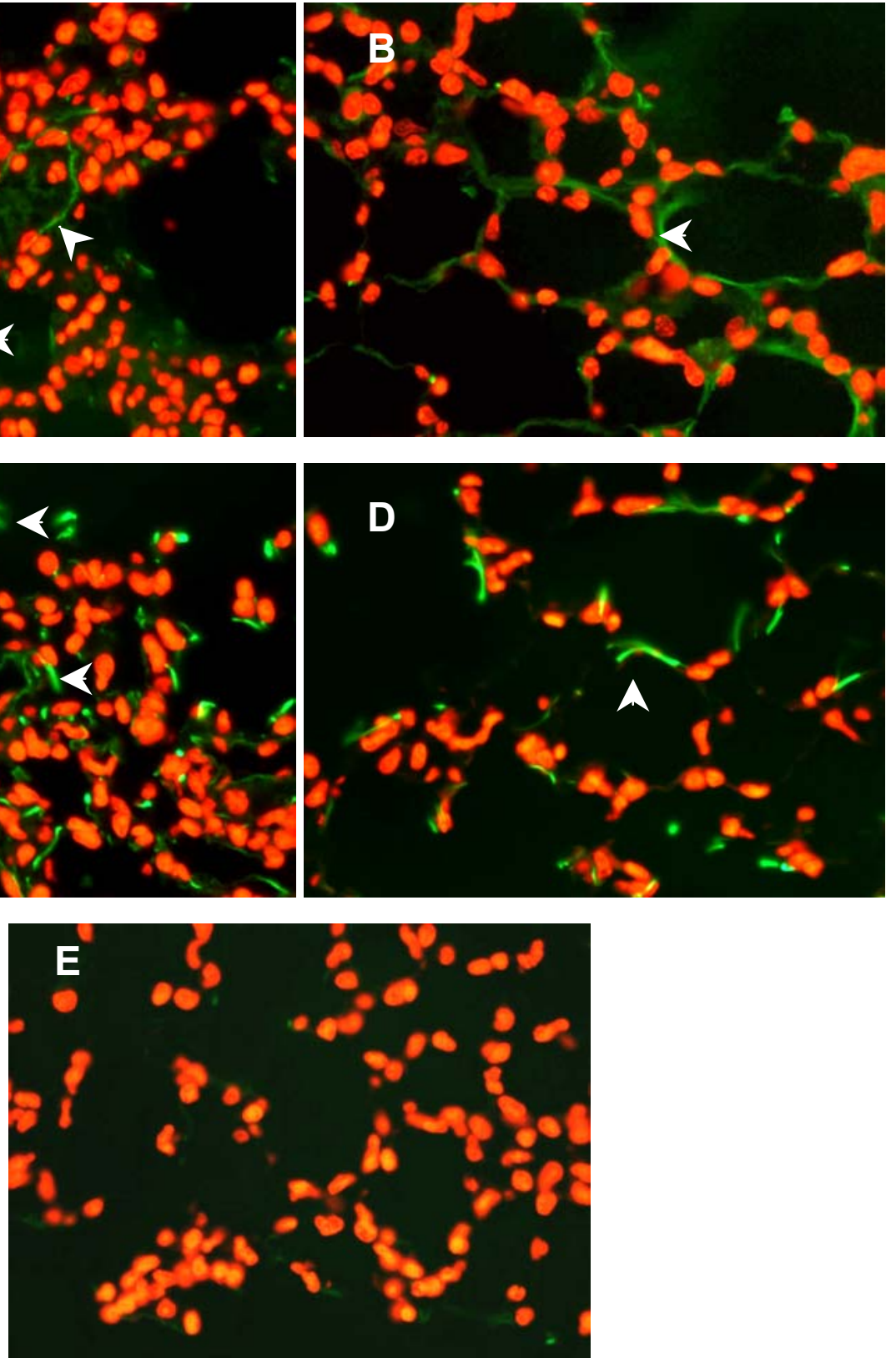

Figura 32 - Imunomarcação da Cx26 em pulmões de camundongos fêmeas submetidos às 25 semanas experimentais. Os camundongos foram sacrificados 25 semanas após a injeção intraperitoneal de uretana $(1,5 \mathrm{~g} / \mathrm{Kg})$. A.C. Área representativa dos pulmões correspondente aos camundongos $\mathrm{C} \times 43^{+/}$, tratados ou não com uretana, respectivamente. B.D. Área representativa dos pulmões correspondentes aos camundongos $\mathrm{C} \times 43^{+/+}$, tratados ou não com uretana, respectivamente. E. Controle negativo da reação. A seta aponta para a marcação correspondente à Cx26. $\mathrm{O}$ anticorpo policlonal contra a Cx26 foi diluído na proporção de 1:200. Os núcleos foram corados com iodeto de propídeo (1:1000). Aumento corresponde a objetiva de 40X 
$\mathrm{Cx} 43^{+/-}$
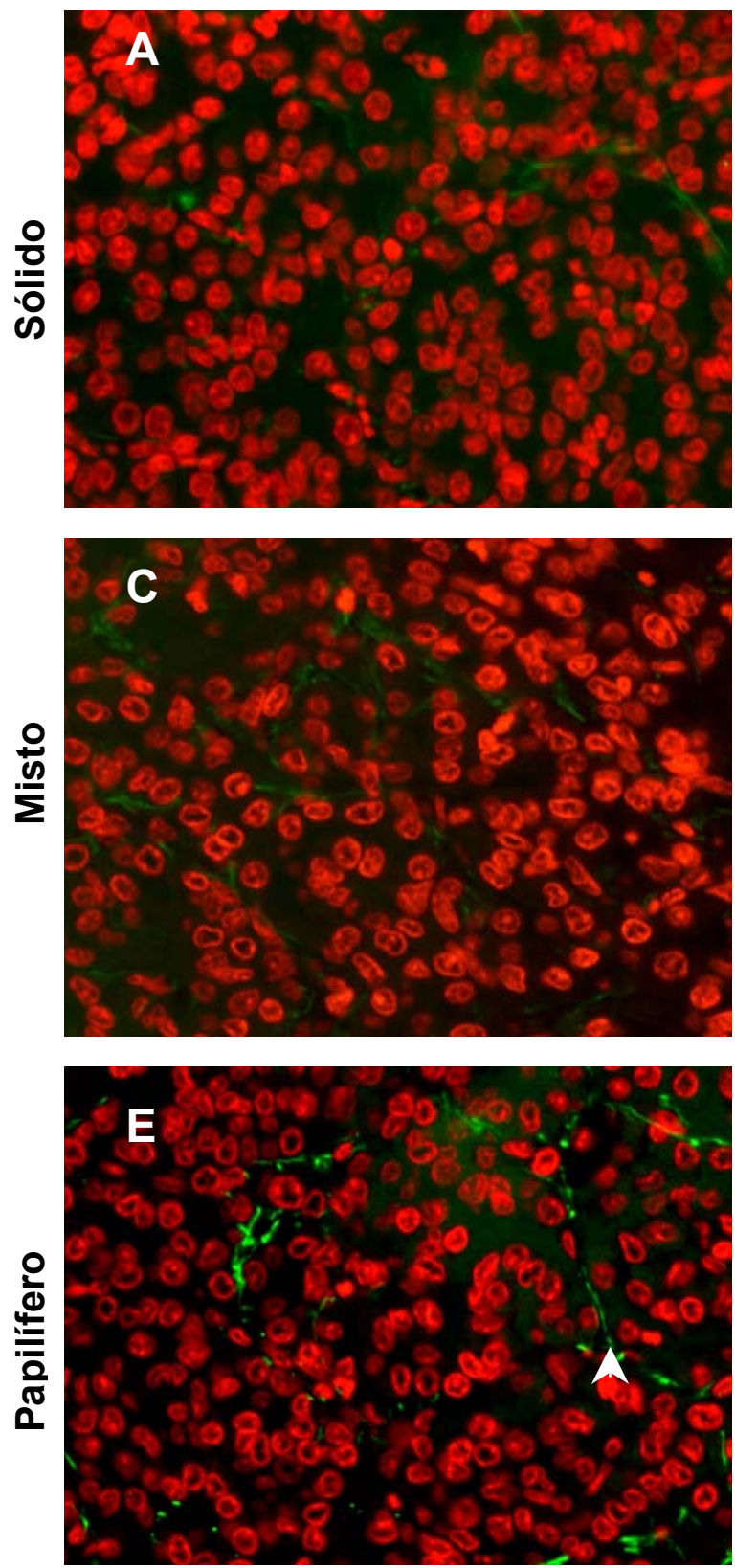

$\mathrm{Cx} 43^{+/+}$
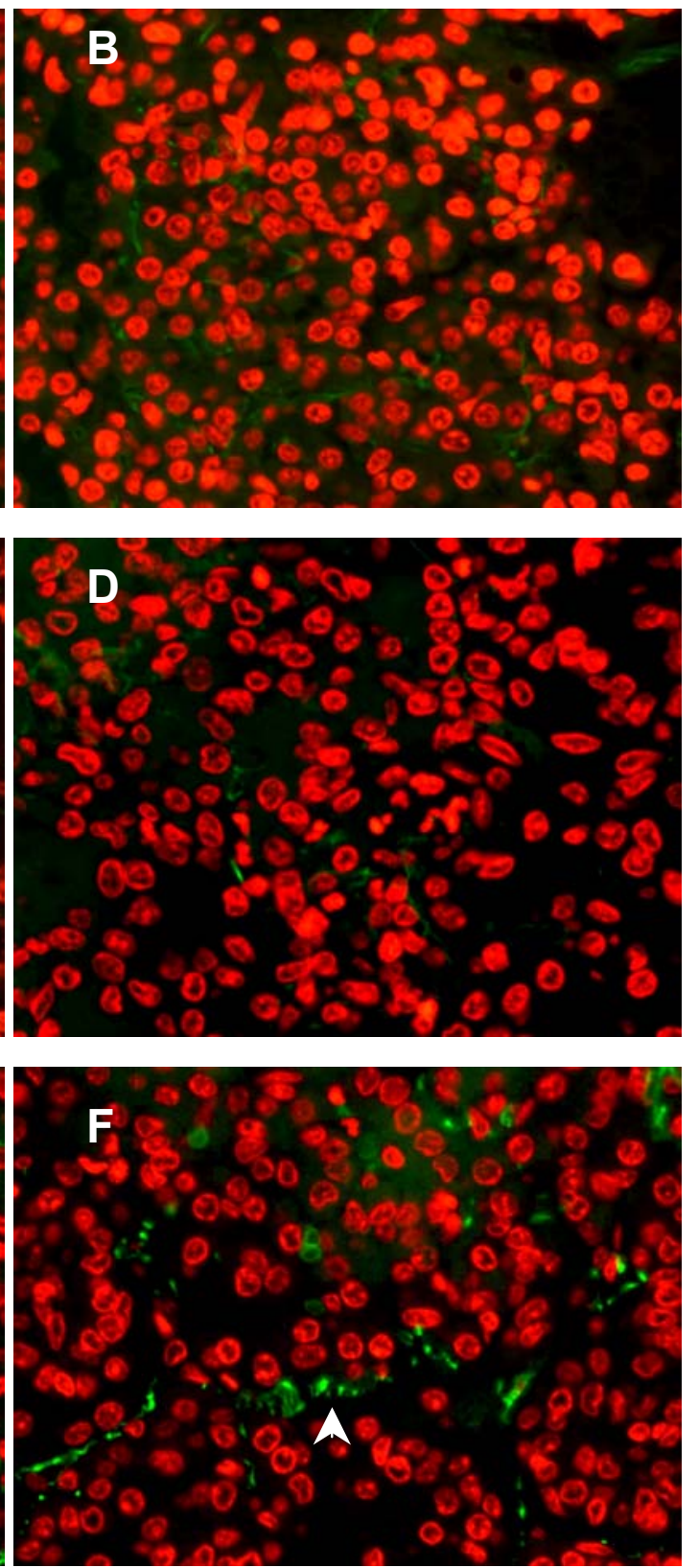

Figura 33 - Imunomarcação da Cx26 em adenomas pulmonares de camundongos machos submetidos às 25 semanas experimentais. Os camundongos foram sacrificados 25 semanas após a injeção intraperitoneal de uretana $(1,5 \mathrm{~g} / \mathrm{Kg})$. A.B. Adenoma sólido correspondente aos camundongos $\mathrm{C} \times 43^{+/-}$e $\mathrm{C} \times 43^{+/+}$, respectivamente. B.D. Adenoma misto correspondente aos camundongos $\mathrm{Cx}_{43^{+/}}$e $\mathrm{Cx} 43^{+/+}$, respectivamente. E.F. Adenoma papilifero correspondentes aos camundongos $\mathrm{C} \times 43^{+/-}$e $\mathrm{C} \times 43^{+/+}$, respectivamente. A seta aponta para a marcação correspondente à Cx26. O anticorpo policlonal contra a Cx26 foi diluído na proporção de 1:200. Os núcleos foram corados com iodeto de propídeo (1:1000). Aumento corresponde a objetiva de $40 \mathrm{X}$ 

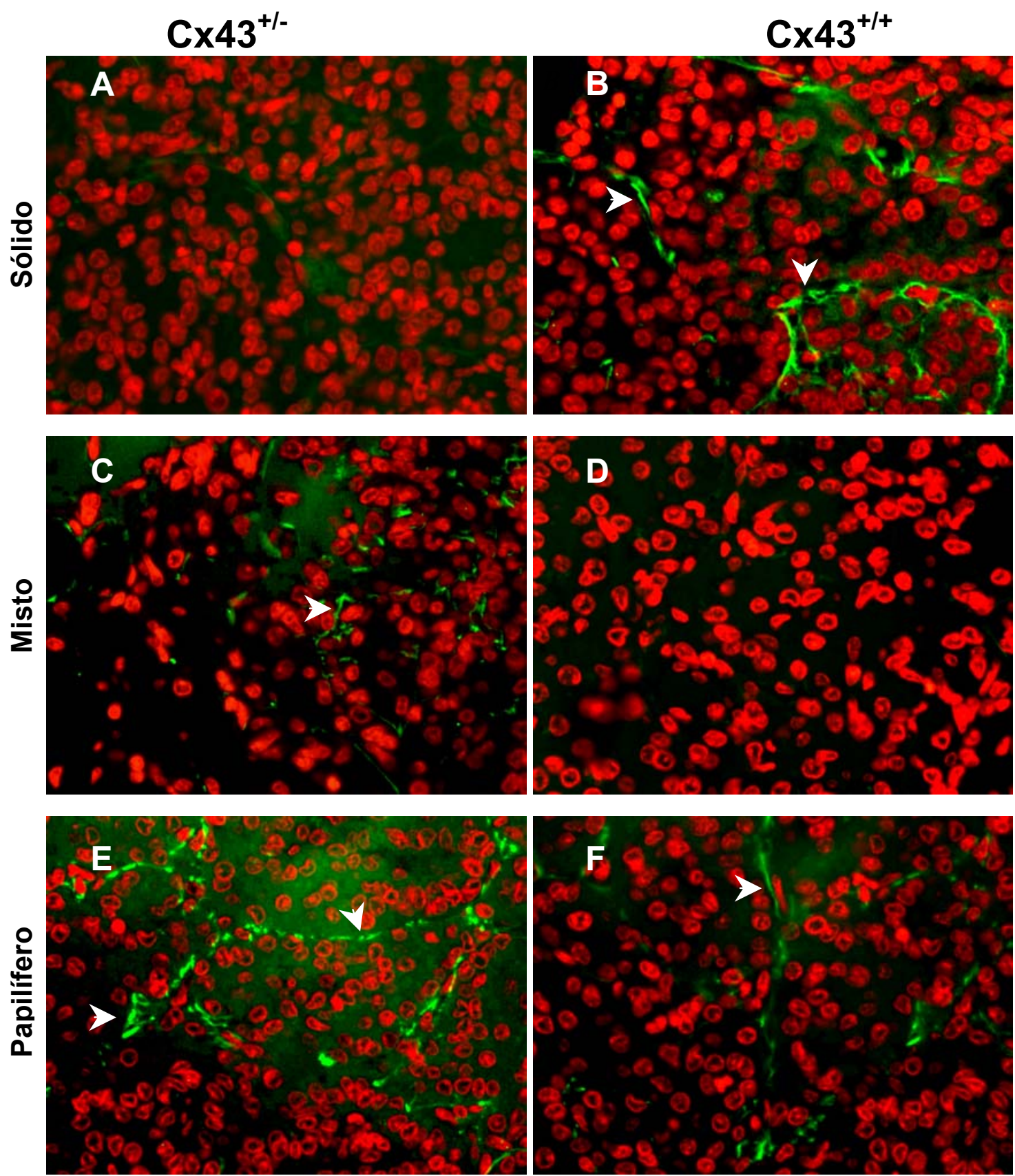

Figura 34 - Imunomarcação da Cx26 em adenomas pulmonares de camundongos fêmeas submetidos às 25 semanas experimentais. Os camundongos foram sacrificados 25 semanas após a injeção intraperitoneal de uretana $(1,5 \mathrm{~g} / \mathrm{Kg})$. A.B. Adenoma sólido correspondente aos camundongos $\mathrm{C} \times 43^{+/-}$e $\mathrm{C} \times 43^{+/+}$, respectivamente. B.D. Adenoma misto correspondente aos camundongos $\mathrm{Cx}_{43^{+/}}$e $\mathrm{Cx} 43^{+/+}$, respectivamente. E.F. Adenoma papilifero correspondentes aos camundongos $\mathrm{C} \times 43^{+/-}$e $\mathrm{C} \times 43^{+/+}$, respectivamente. A seta aponta para a marcação correspondente à Cx26. O anticorpo policlonal contra a Cx26 foi diluído na proporção de 1:200. Os núcleos foram corados com iodeto de propídeo (1:1000). Aumento corresponde a objetiva de $40 \mathrm{X}$ 


\subsubsection{Imunomarcação da $\mathrm{Cx32}$ no tecido pulmonar submetido ou não ao tratamento com uretana e nos respectivos adenomas}

As figuras de imunomarcação correspondentes a Cx32 podem ser encontradas nas figuras 35 e 36, para camundongos machos e fêmeas respectivamente.

Tanto para os camundongos machos $\mathrm{C} \times 43^{+/-}$e $\mathrm{Cx} 43^{+/+}$tratados com uretana (Figuras 35 A e B) o que se verifica é uma redução na intensidade de marcação quando se compara com a marcação realizada sobre cortes histológicos de camundongos não tratados com uretana (Figuras $35 \mathrm{C}$ e D). Apesar do tratamento com uretana praticamente extinguir a marcação da $\mathrm{Cx32}$, a presença de regiões puntiformes marcadas entre as células dos alvéolos é verificada. Esta marcação é mais acentuada nos camundongos $\mathrm{Cx} 43^{+/-}$(Figura $35 \mathrm{~A}$ ) que nos camundongos $\mathrm{C}_{4} 43^{+/+}$(Figura $\left.35 \mathrm{~B}\right)$. Nos camundongos $\mathrm{Cx}^{+/++}$(Figura $35 \mathrm{~B}$ ) a marcação é situada próxima ao núcleo das células.

Nos camundongos não tratados com uretana (Figuras $35 \mathrm{Ce}$ D) pode se observar uma marcação intensa e citoplasmática. Diferente do que se observou para a Cx43, apenas algumas células são coradas (possivelmente APTII).

Quando se verifica a marcação efetuada em cortes histológicos oriundos de camundongos fêmeas (Figura 36), verifica-se uma marcação mais intensa que aquela dos camundongos machos. Os camundongos $\mathrm{C} \times 43^{+/-}$(Figura $36 \mathrm{~B}$ ) também apresentam marcação citoplasmática, menos intensa, e uma marcação observada na região de contato entre as células.

Os camundongos $\mathrm{Cx} 43^{+/-}$não tratados com uretana (Figura $36 \mathrm{C}$ ) apresentam marcação para a Cx32 citoplasmática e amplamente distribuída pelo alvéolo. Nos 
camundongos $\mathrm{Cx} 43^{+/+}$a marcação é citoplasmática e restrita a algumas células (Figura $36 \mathrm{D})$.

Nos adenomas pulmonares de camundongos machos (Figura 37) é possível verificar alguma marcação para a Cx32. A marcação citoplasmática é mais evidente nos adenomas sólidos proveniente de camundongos $\mathrm{Cx} 43^{+/+}$(Figura $37 \mathrm{~B}$ ). Nos adenomas papilíferos de camundongos machos e fêmeas (Figuras 37 E e F) é possível notar uma marcação citoplasmática menos intensa; confundida com o background. Entre os camundongos fêmeas (Figura 38), apenas uma marcação muito fraca é observada nos adenomas papilíferos (Figuras 38 E e F) destes camundongos. 



Figura 35 - Imunomarcação da Cx32 em pulmões de camundongos machos submetidos às 25 semanas experimentais. Os camundongos foram sacrificados 25 semanas após a injeção intraperitoneal de uretana $(1,5 \mathrm{~g} / \mathrm{Kg})$. A.C. Área representativa dos pulmões correspondente aos camundongos $\mathrm{Cx}_{4} 3^{+/-}$, tratados ou não com uretana, respectivamente. B.D. Área representativa dos pulmões correspondentes aos camundongos $\mathrm{C} \times 43^{+/+}$, tratados ou não com uretana, respectivamente. E. Controle negativo da reação. A seta aponta para a marcação correspondente à Cx32. $\mathrm{O}$ anticorpo policlonal contra a Cx32 foi diluído na proporção de 1:500. Os núcleos foram corados com iodeto de propídeo (1:1000). Aumento corresponde a objetiva de 40X 

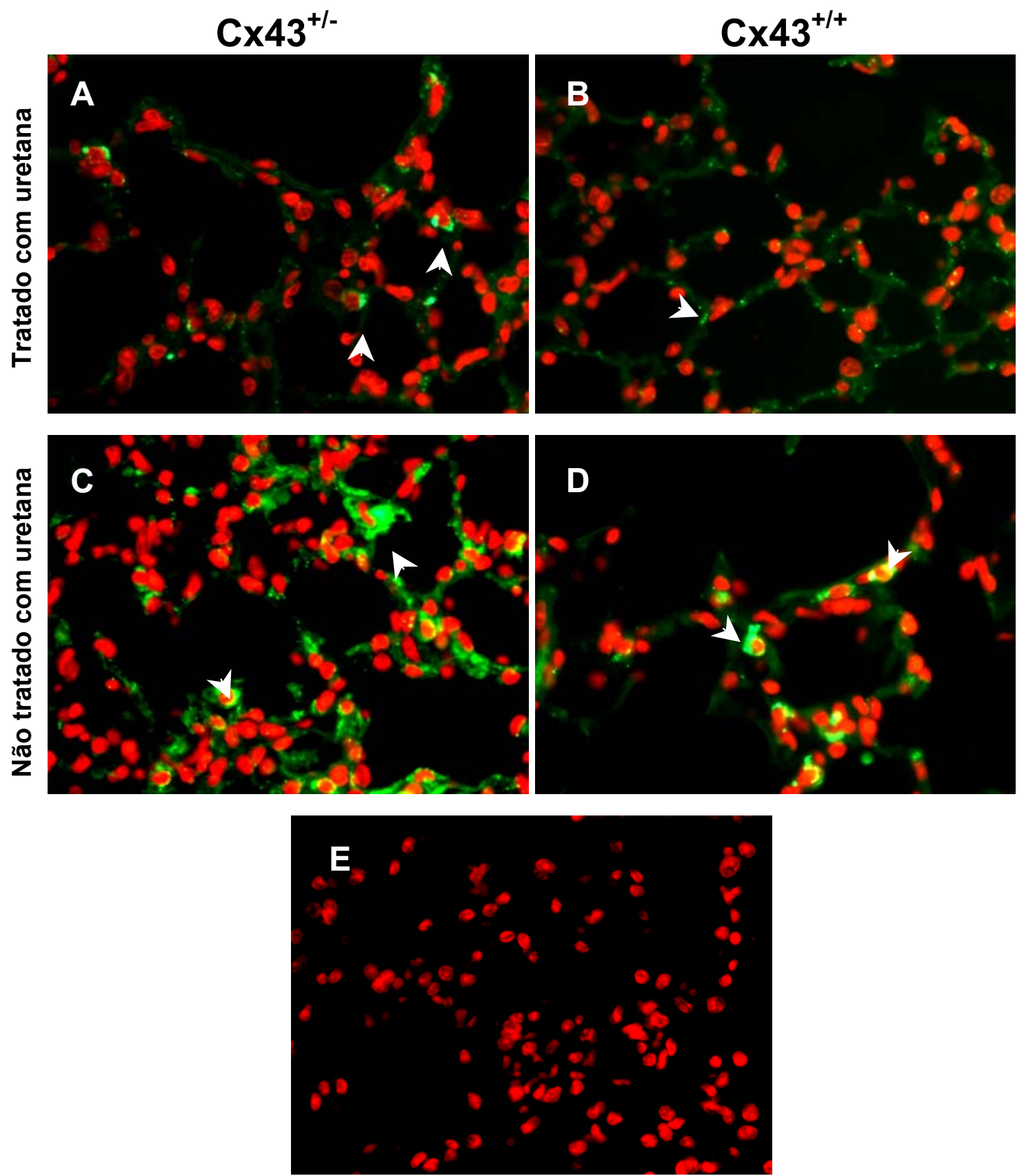

Figura 36 - Imunomarcação da Cx32 em pulmões de camundongos fêmeas submetidos às 25 semanas experimentais. Os camundongos foram sacrificados 25 semanas após a injeção intraperitoneal de uretana $(1,5 \mathrm{~g} / \mathrm{Kg})$. A.C. Área representativa dos pulmões correspondente aos camundongos $\mathrm{Cx} 43^{+/}$, tratados ou não com uretana, respectivamente. B.D. Área representativa dos pulmões correspondentes aos camundongos $\mathrm{C} \times 43^{+/+}$, tratados ou não com uretana, respectivamente. E. Controle negativo da reação. A seta aponta para a marcação correspondente à Cx32. $\mathrm{O}$ anticorpo policlonal contra a Cx32 foi diluído na proporção de 1:500. Os núcleos foram corados com iodeto de propídeo (1:1000). Aumento corresponde a objetiva de 40X 

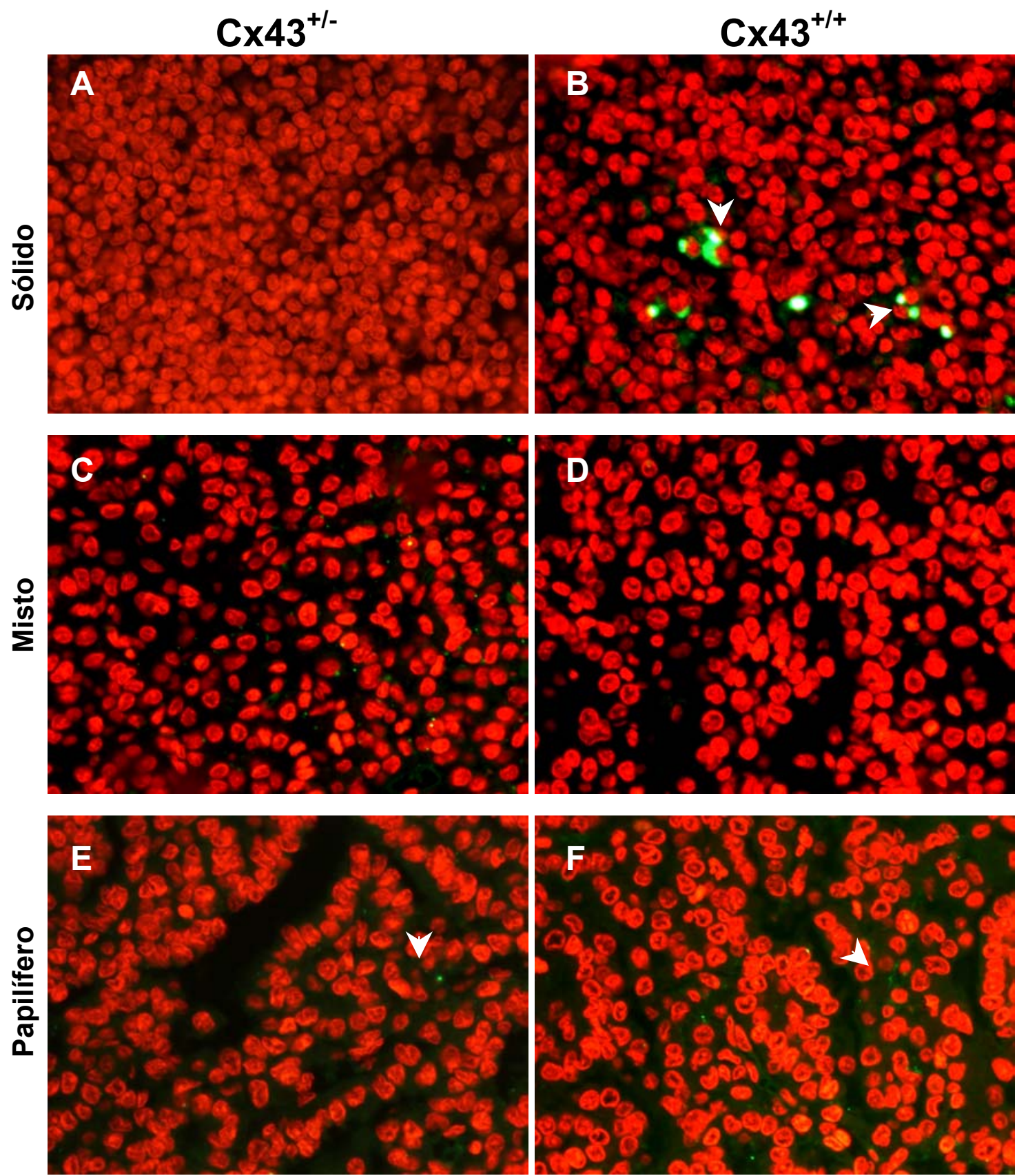

Figura 37 - Imunomarcação da Cx32 em adenomas pulmonares de camundongos machos submetidos às 25 semanas experimentais. Os camundongos foram sacrificados 25 semanas após a injeção intraperitoneal de uretana $(1,5 \mathrm{~g} / \mathrm{Kg})$. A.B. Adenoma sólido correspondente aos camundongos $\mathrm{Cx}_{43^{+/}}$e $\mathrm{C} \times 43^{+/ /}$, respectivamente. B.D. Adenoma misto correspondente aos camundongos $\mathrm{C}_{4} 43^{+/-}$e $\mathrm{C} \times 43^{+/+}$, respectivamente. E.F. Adenoma papilifero correspondentes aos camundongos $\mathrm{C} \times 43^{+/-}$e $\mathrm{Cx} 43^{+/+}$, respectivamente. A seta aponta para a marcação correspondente à Cx32. O anticorpo policlonal contra a Cx32 foi diluído na proporção de 1:500. Os núcleos foram corados com iodeto de propídeo (1:1000). Aumento corresponde a objetiva de $40 \mathrm{X}$ 
$\mathrm{C} \times 43^{+1-}$
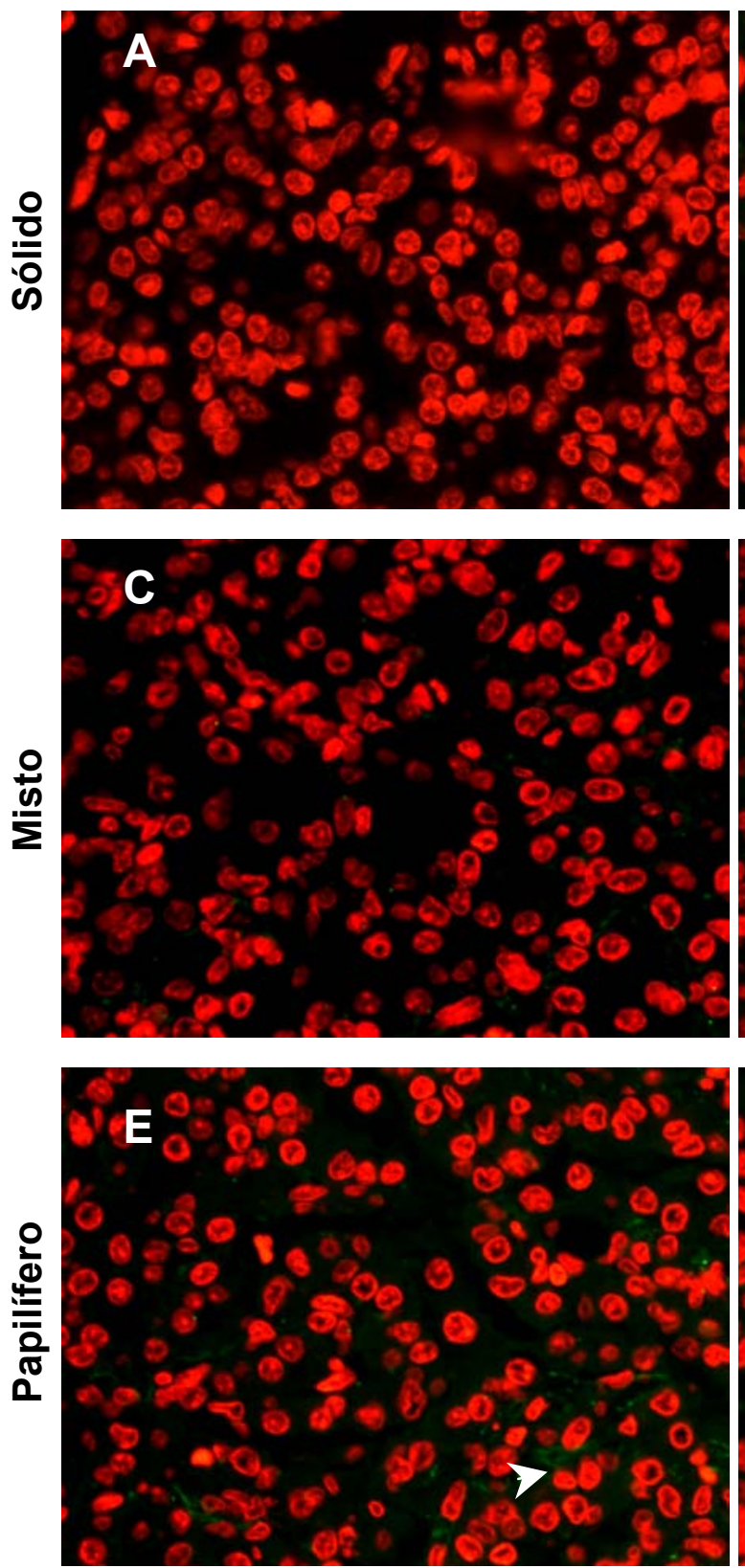

$\mathrm{Cx} 43^{+/+}$
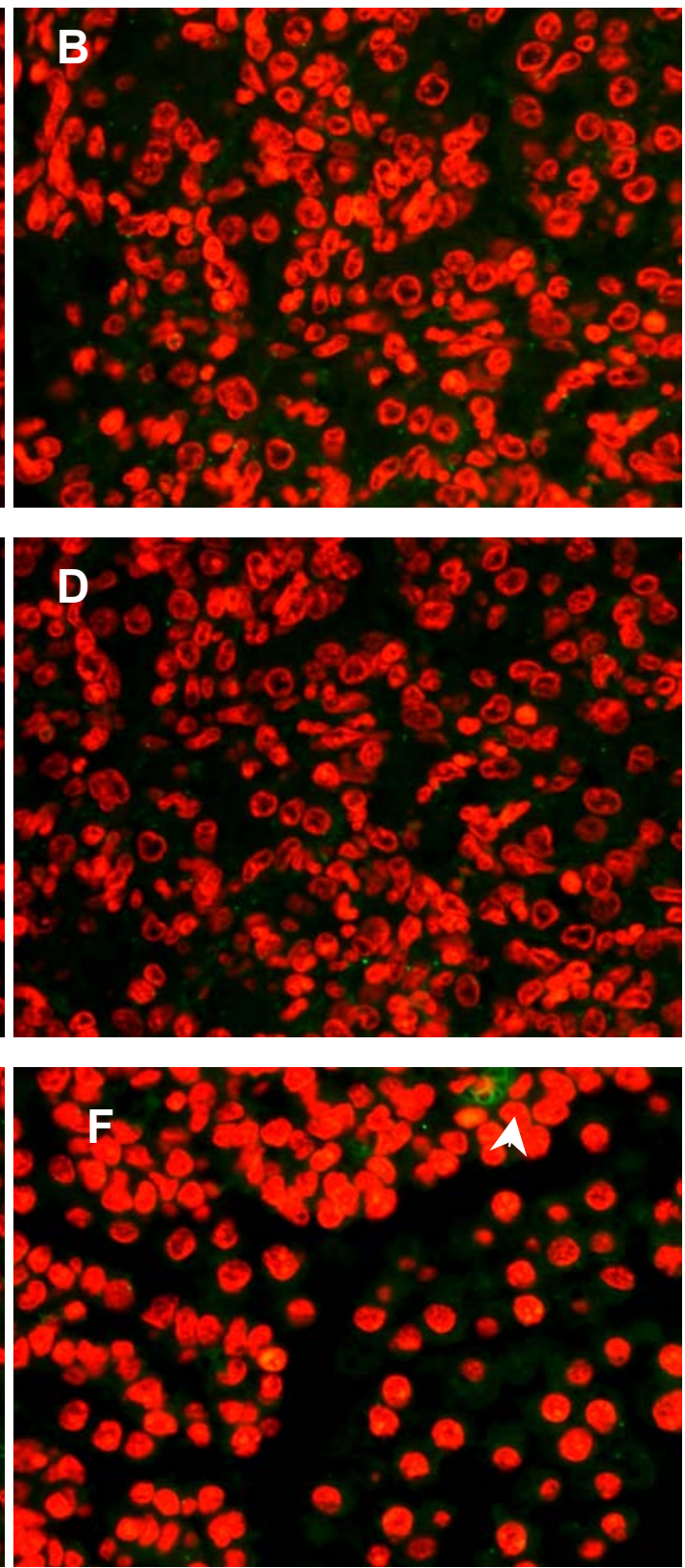

Figura 38 - Imunomarcação da Cx32 em adenomas pulmonares de camundongos fêmeas submetidos às 25 semanas experimentais. Os camundongos foram sacrificados 25 semanas após a injeção intraperitoneal de uretana $(1,5 \mathrm{~g} / \mathrm{Kg})$. A.B. Adenoma sólido correspondente aos camundongos $\mathrm{C} \times 43^{+/-}$e $\mathrm{C} \times 43^{+/+}$, respectivamente. B.D. Adenoma misto correspondente aos camundongos $\mathrm{Cx}_{43^{+/}}$e $\mathrm{Cx} 43^{+/+}$, respectivamente. E.F. Adenoma papilifero correspondentes aos camundongos $\mathrm{C} \times 43^{+/-}$e $\mathrm{C} \times 43^{+/+}$, respectivamente. A seta aponta para a marcação correspondente à Cx32. O anticorpo policlonal contra a Cx32 foi diluído na proporção de 1:500. Os núcleos foram corados com iodeto de propídeo (1:1000). Aumento corresponde a objetiva de $40 \mathrm{X}$ 


\subsubsection{Imunomarcação da Cx46 no tecido pulmonar submetido ou não ao tratamento com uretana e nos respectivos adenomas}

A marcação correspondente à Cx46 pode ser verificada nas figuras 39 e 40 . Nos cortes histológicos oriundos de camundongos tratados com uretana não se observa marcação para a Cx46 (Figuras 39 A e B). Tanto os camundongos Cx43+/quanto os $\mathrm{C} \times 43^{+/+}$machos apresentam marcação citoplasmática para a Cx46 (Figuras 39 C e D).

A Cx46, também, diferentemente da marcação observada para a Cx43, apresenta marcação restrita a algumas células nos alvéolos pulmonares.

A marcação para a Cx46 efetuada em cortes histológicos de pulmões de camundongos fêmea pode ser encontrada na figura 40. Da mesma forma que aquela dos camundongos machos, não se observa marcação após o tratamento com uretana (Figuras 40 A e B). Nos camundongos não tratados com uretana (Figuras 40 C e D) a marcação é citoplasmática e intensa; não se verificando diferença na intensidade de marcação entre os camundongos dos diferentes genótipos.

A marcação realizada nos adenomas de camundongos machos pode ser verificada na figura 41. Observa-se marcação para a Cx46 em todos os três tipos de adenomas pulmonares induzidos pela uretana (Figura 41) independente do genótipo, $\mathrm{C} \times 43^{+/-}$ou $\mathrm{C} \times 43^{+/+}$, e do sexo dos camundongos. A marcação verificada para os adenomas sólidos e mistos (Figuras 41 A, B, C e D) é citoplasmátcia. A marcação é mais intensa e citoplasmática nos adenomas papilíferos provenientes dos camundongos $\mathrm{C} \times 43^{+/-}$e $\mathrm{Cx} 43^{+/+}$(Figuras $41 \mathrm{E}$ e F). A marcação é mais intensa nos camundongos $\mathrm{C} \times 43^{+/-}$(Figuras $41 \mathrm{E}$ ). 
A Cx46 nas fêmeas é observada com maior intensidade de marcação por entre as células dos adenomas mistos (Figuras $42 \mathrm{C}$ e D) dos camundongos de ambos os genótipos. Alguma marcação é evidenciada entre os adenomas sólidos (Figuras 42 A e B) e papilíferos (Figuras 42 E e F) destes camundongos. 

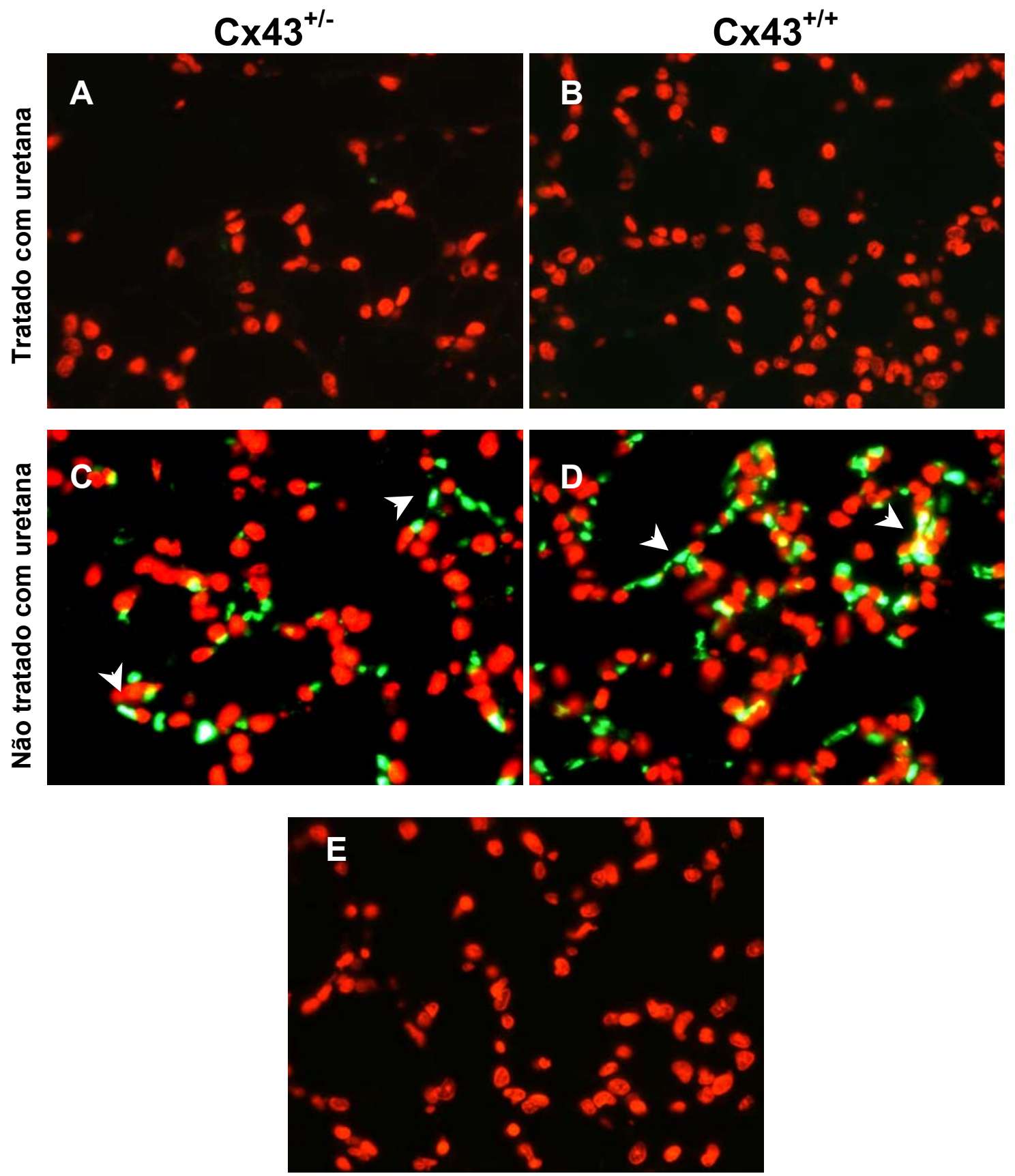

Figura 39 - Imunomarcação da Cx46 em pulmões de camundongos machos submetidos às 25 semanas experimentais. Os camundongos foram sacrificados 25 semanas após a injeção intraperitoneal de uretana $(1,5 \mathrm{~g} / \mathrm{Kg})$. A.C. Área representativa dos pulmões correspondente aos camundongos $\mathrm{C} \times 43^{+/}$, tratados ou não com uretana, respectivamente. B.D. Área representativa dos pulmões correspondentes aos camundongos $\mathrm{C} \times 43^{+/+}$, tratados ou não com uretana, respectivamente. E. Controle negativo da reação. A seta aponta para a marcação correspondente à Cx46. $\mathrm{O}$ anticorpo policlonal contra a Cx46 foi diluído na proporção de 1:3000. Os núcleos foram corados com iodeto de propídeo (1:1000). Aumento corresponde a objetiva de 40X 

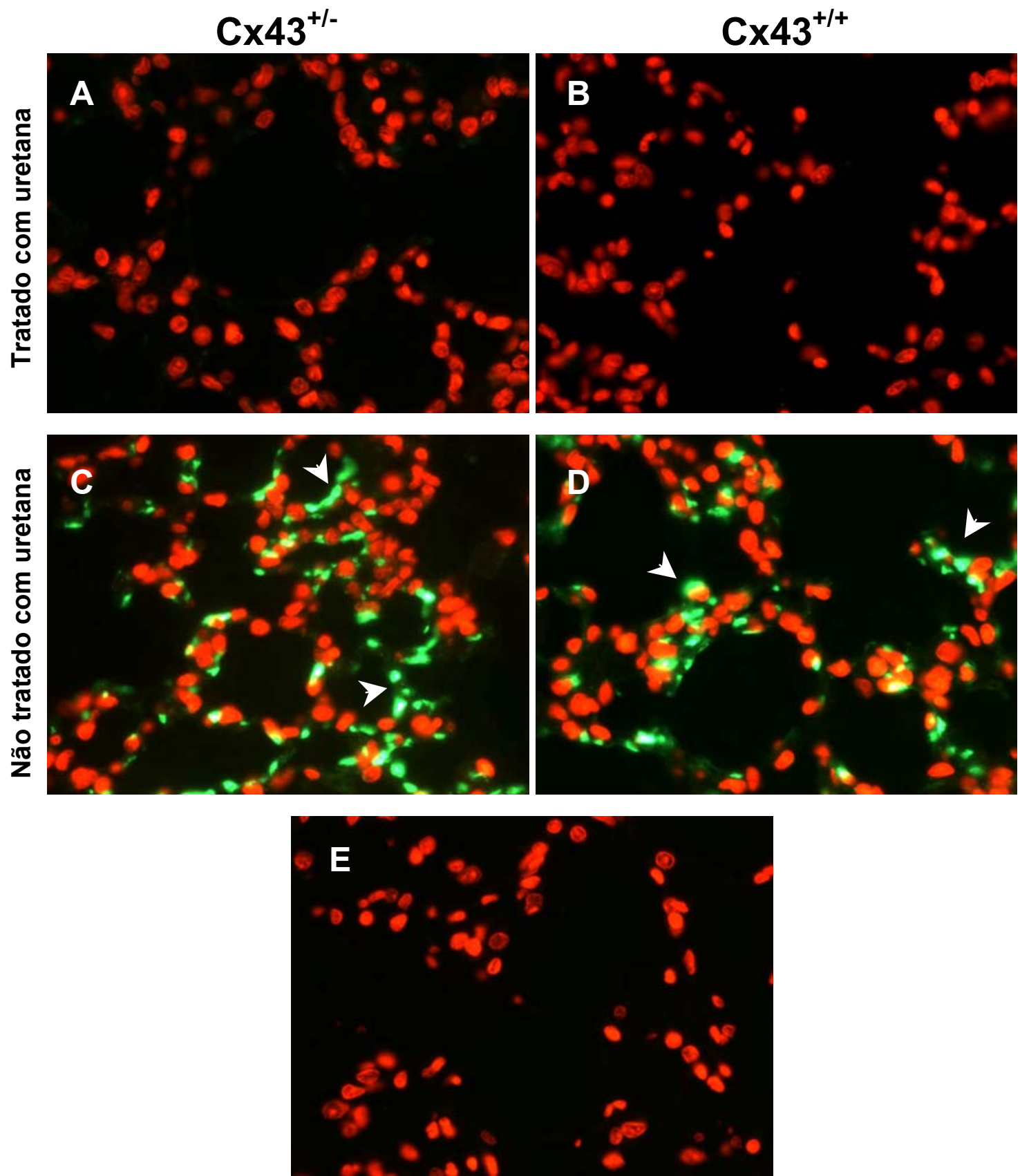

Figura 40 - Imunomarcação da Cx46 em pulmões de camundongos fêmeas submetidos às 25 semanas experimentais. Os camundongos foram sacrificados 25 semanas após a injeção intraperitoneal de uretana $(1,5 \mathrm{~g} / \mathrm{Kg})$. A.C. Área representativa dos pulmões correspondente aos camundongos $\mathrm{Cx}_{4} 3^{+/-}$, tratados ou não com uretana, respectivamente. B.D. Área representativa dos pulmões correspondentes aos camundongos $\mathrm{C} \times 43^{+/+}$, tratados ou não com uretana, respectivamente. E. Controle negativo da reação. A seta aponta para a marcação correspondente à Cx46. $\mathrm{O}$ anticorpo policlonal contra a Cx46 foi diluído na proporção de 1:3000. Os núcleos foram corados com iodeto de propídeo (1:1000). Aumento corresponde a objetiva de 40X 

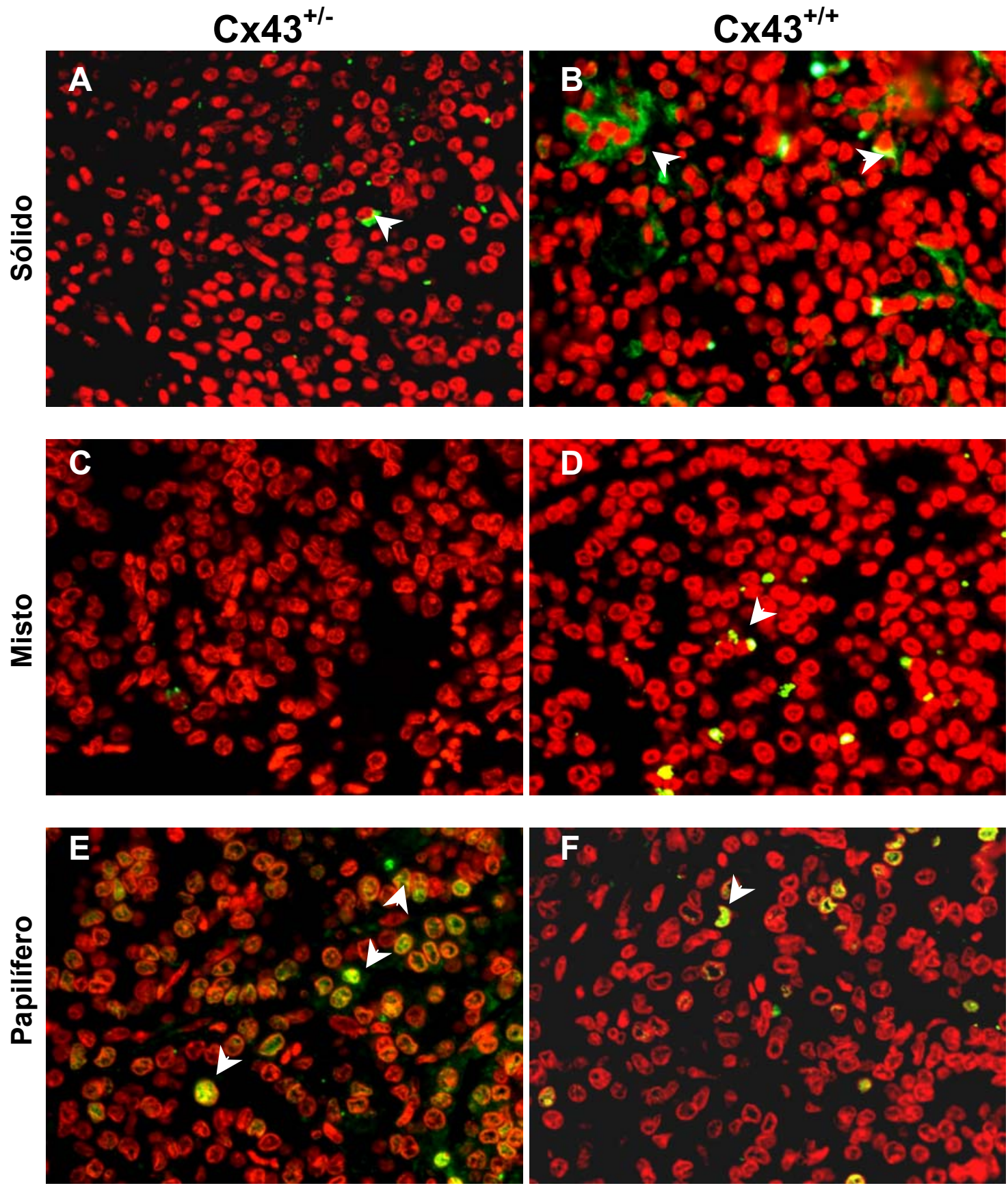

Figura 41 - Imunomarcação da Cx46 em adenomas pulmonares de camundongos machos submetidos às 25 semanas experimentais. Os camundongos foram sacrificados 25 semanas após a injeção intraperitoneal de uretana $(1,5 \mathrm{~g} / \mathrm{Kg})$. A.B. Adenoma sólido correspondente aos camundongos $\mathrm{Cx}_{43^{+/}}$e $\mathrm{C} \times 43^{+/+}$, respectivamente. B.D. Adenoma misto correspondente aos camundongos $\mathrm{C} \times 43^{+/}$e $\mathrm{Cx} 43^{+++}$, respectivamente. E.F. Adenoma papilífero correspondentes aos camundongos $\mathrm{C} \times 43^{+/-}$e $\mathrm{C} \times 43^{+/+}$, respectivamente. A seta aponta para a marcação correspondente à Cx46. O anticorpo policlonal contra a Cx46 foi diluído na proporção de 1:3000. Os núcleos foram corados com iodeto de propídeo (1:1000). Aumento corresponde a objetiva de 40X 

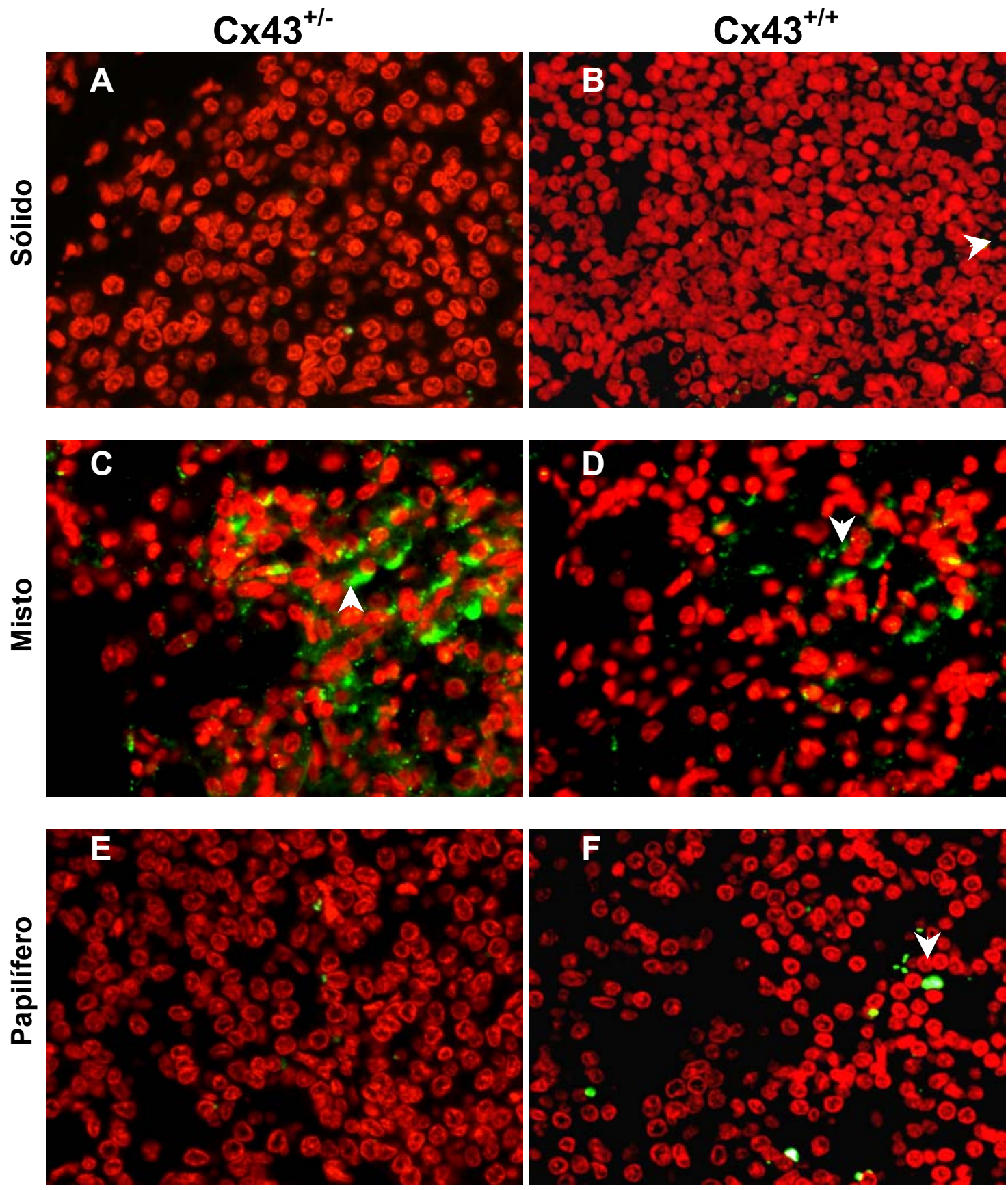

Figura 42 - Imunomarcação da Cx46 em adenomas pulmonares de camundongos fêmeas submetidos às 25 semanas experimentais. Os camundongos foram sacrificados 25 semanas após a injeção intraperitoneal de uretana $(1,5 \mathrm{~g} / \mathrm{Kg})$. A.B. Adenoma sólido correspondente aos camundongos $\mathrm{C}_{4} 43^{+/-}$e $\mathrm{C} \times 43^{+/+}$, respectivamente. B.D. Adenoma misto correspondente aos camundongos $\mathrm{Cx}_{43^{+/-}}$e $\mathrm{C} \times 43^{+/+}$, respectivamente. E.F. Adenoma papilífero correspondentes aos camundongos $\mathrm{C} \times 43^{+/-}$e $\mathrm{C} \times 43^{+/+}$, respectivamente. A seta aponta para a marcação correspondente à Cx46. O anticorpo policlonal contra a $\mathrm{Cx} 46$ foi diluído na proporção de 1:3000. Os núcleos foram corados com iodeto de propídeo (1:1000). Aumento corresponde a objetiva de 40X 


\subsection{RESULTADOS DOS ESTUDOS IN VITRO OBTIDOS NA UNIVERSIDADE DE POITIERS}

\subsubsection{Estabelecimento da cultura celular primária dos APTII}

As características gerais e morfológicas de nossos primeiros ensaios na Universidade de Poitiers, na tentativa de estabelecer a cultura primária de APTII, foram realizados com meio brochial epithelial cell growth medium (BEGM) como descrito por Rice et al. (2002). Após várias tentativas, aproximadamente 2 meses, não foi possível obter boas condições de cultivo para as células isoladas. Dessa forma, os APTIls foram cultivados em meio padrão, ou seja, DMEM e foram estimulados a proliferar com keratinocyte growth factor (KGF) $10 \mu \mathrm{g} / \mathrm{ml}$ de meio de cultivo. A digestão enzimática com Dispase e a desagregação mecânica dos pulmões produziram $10,7 \pm 5,5$ milhões de células por camundongo $(n=97)$.

Com a purificação usando-se lgG foi possível produzir uma suspensão final com cerca de 6,06 $\pm 2,3$ milhões de células, com recuperação de cerca de $91,04 \% \pm 1,95$. Para a identificação destas células isoladas, nós efetuamos a marcação dos corpos lamelares através da técnica do tetróxido de ósmio/ácido tânico (Figura 44 e 45). Esta coloração foi efetuada na própria placa de cultivo com dois dias. Com isso, 500 células em uma área pré-determinada na objetiva do microscópio, foram contadas e classificadas pela presença ou não de numerosos grânulos escuros no citoplasma (corpos lamelares). O emprego desta técnica revelou que 95,89 \% \pm 0,21 das células isoladas eram APTII (Figura 44 e 45) e, $92,87 \% \pm 3,97$ das células foram viáveis pelo teste do corante vital de

exclusão (Tripan Blue). A análise ultraestrutural confirmou os resultados de 
identificação da cultura comentados acima, baseados nas características morfológicos (Figura 49).

Nossas triagens preliminares demonstraram que os APTII de camundongos não se aderem ao plástico da placa de cultura tratada (Figuras 46 $A, B, C$ e D), o que confirma os resultados apresentados anteriormente por Corti et al. (1996). Entretanto, células contaminantes da cultura de APTII, como as células endoteliais e os fibroblastos (Figura 46 D), se aderem firmemente ao plástico da placa de cultura em poucas horas. Assim, uma incubação inicial sobre plástico de 4 horas foi feita para aumentar a pureza da cultura dos APTII. Subseqüentemente, as células que não se aderiram foram transferidas para placas de cultura de $35 \mathrm{~mm}$ cobertas com Matrigel/colágeno (70:30\%), na qual se mostraram aderidas em menos de 24 horas. Os APTII em meio acrescido de KGF tem a capacidade de inibir o crescimente de fibroblastos por mais de 7 dias em cultura (Figuras 46 F) em acordo com Pan et al. (2001).

A morfologia da cultura celular dos APTII foi acompanhada durante 8 dias de incubação. A morfologia destas células foi acompanhada e notificada nos dias 2, 4, 6 e 8 de incubação (Figura 43), através de microscópio de contraste de fase e microscopia óptica para células fixadas, com tetróxido de ósmio, no segundo dia de incubação (Figuras 44 e 45). Poucas células se aderiram ao matrigel no primeiro dia de incubação. No segundo dia, estas células se apresentavam com as mais diversas morfologias (Figuras 43 A e B). Entre as morfologias observadas podemos descrever a morfologia completamente achatada, a redonda, a morfologia amebóide, a ramificada e a esférica. No quarto dia de incubação a população observada já era mais que o dobro da registrada no segundo dia (Figuras $43 \mathrm{C}$ e D). Até o quarto dia a morfologia destas células era 
completamente diferente da morfologia característica de células epiteliais (ver controle realizado com células IAR20 de origem epitelial (Figura 47); se assemelhando à morfologia de fibroblastos, achatada e se espalhando na tentativa de formar uma monocamada. Quando as células se apresentaram mais confluentes, no sexto dia de incubação (Figuras 43 E e F), a morfologia observada era a mesma observada para células de origem epitelial em cultura (Figuras 47 A e B), com "domes" característicos (Figuras 43 C e D; círculo vermelho). As mesmas características foram anteriormente reportadas por Corti et al. (1996) e Hasegawa et al. (2001). A maioria das células apresentavam projeções citoplasmáticas, aparentemente em contato direto com outras células (Figuras 45). Os corpos lamelares foram observados dentro dos bulbos ou dentro das projeções (Figura 45; círculo vermelho). No quarto dia (Figuras 43; C e D), muitas células ainda apresentavam formato irregular, mas, a monocamada já podia ser observada. No sexto dia (Figuras 43 E e F), o formato das células já era mais achatado e poligonal e a quantidade de corpos lamelares apresentava-se diminuída e a morfologia semelhante a de células de origem epitelial como as IAR20 (Figura 47). A literatura descreve esta perda de corpos lamelares em cultura e uma relação entre o crescimento de células de origem não epitelial não é uma justificativa, uma vez que conseguimos mantê-las em cultura por mais que 7 dias (Figura 46 F) (CORTI et al., 1996). Ainda com o objetivo de nos certificarmos que as células isoladas eram pneumócitos, foi efetuada a marcação e a observação dos corpos lamelares em microscopia de varredura (Figura 48) e eletrônica (Figura 49). 



Figura 43 - Cultura de células de APTII purificada de camundongos observadas em microscópio de contraste de fase nos dias 2 (A, B), 4 (C, D), 6 (E, F) e, 8 (G, H). Numerosas projeções citoplasmáticas (flecha verde), células se aderindo (flecha amarela) e hemácias remanescentes (flecha vermelha), podem ser observadas no segundo dia de incubação (A e B). Até o quarto dia a morfologia fibroblástica pôde ser observada, assim como a presença de domes (círculo vermelho (C e D)). A característica poligonal pôde ser observada a partir do sexto dia de incubação (E e F). A forma irregular pôde ser observada até o oitavo dia de incubação ( $\mathbf{G}$ e H). A morte celular por apoptose encontra-se indicada pelas cabeças de setas amarelas $(\mathbf{H})$ 




Figura 44 - APTII em cultura primária. As células foram isoladas, purificadas e cultivadas em DMEM contendo KGF $6 \times 10^{6}$ células/ml em Matrigel/colágeno (70:30 vol/vol). Após 48 horas, as células foram coradas com tetróxido de ósmio para realçar os corpos lamelares (marcação puntiforme corada em preto). Barra $=50 \mu \mathrm{m}$ 


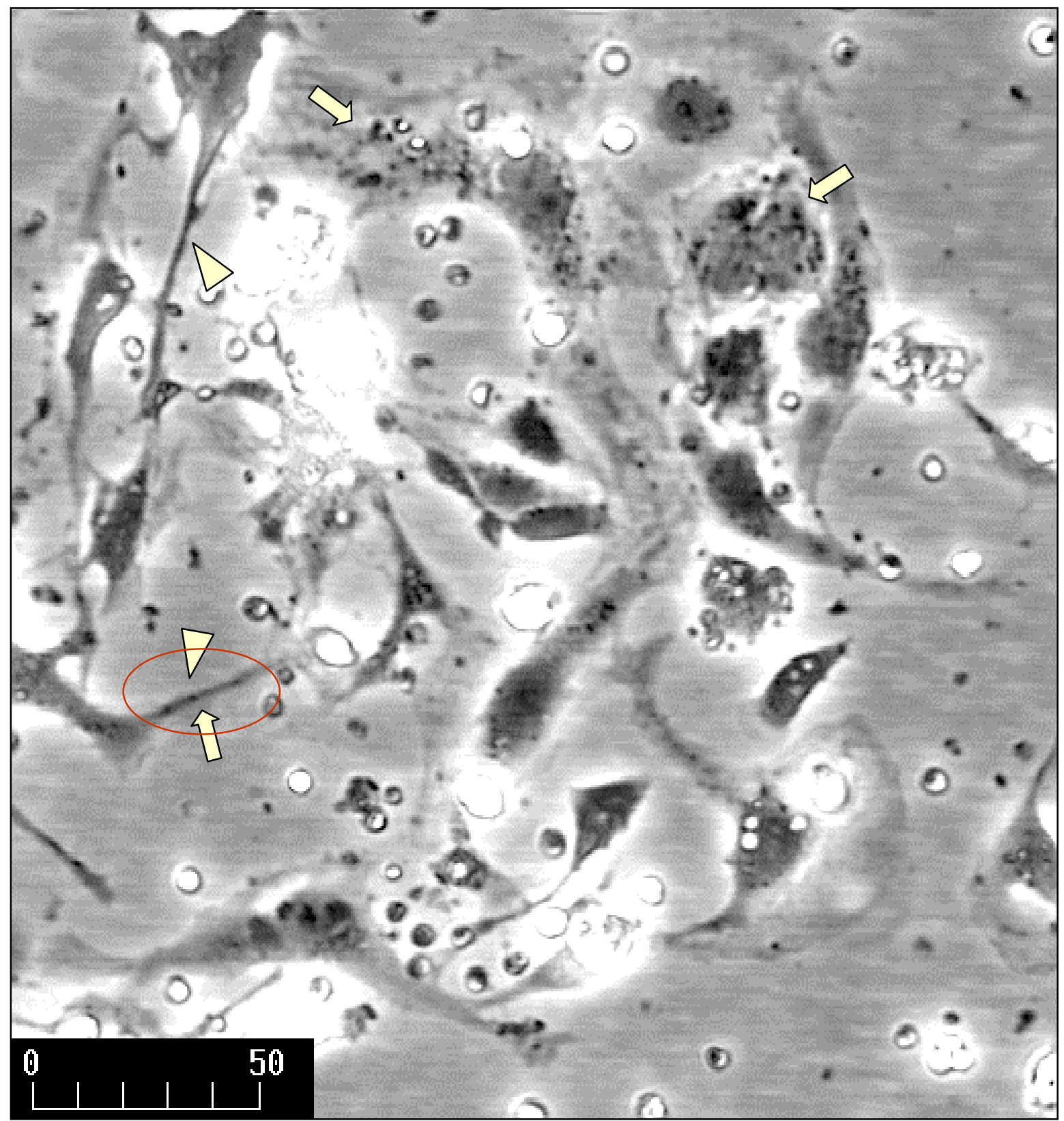

Figura 45 - APTII em cultura primária. As células foram isoladas, purificadas e cultivadas em DMEM contendo KGF $6 \times 10^{6}$ células/ml em Matrigel/colágeno (70:30 vol/vol). Após 48 horas, as células foram coradas com tetróxido de ósmio para realçar os corpos lamelares. $50 \mu \mathrm{m}$. As setas apontam para os corpos lamelares corados em preto. As cabeças de setas indicam os prolongamentos dos APTII procurando contato com outras células. Os corpos lamelares podem ser encontrados em áreas de projeções citoplasmáticas (círculo vermelho) 

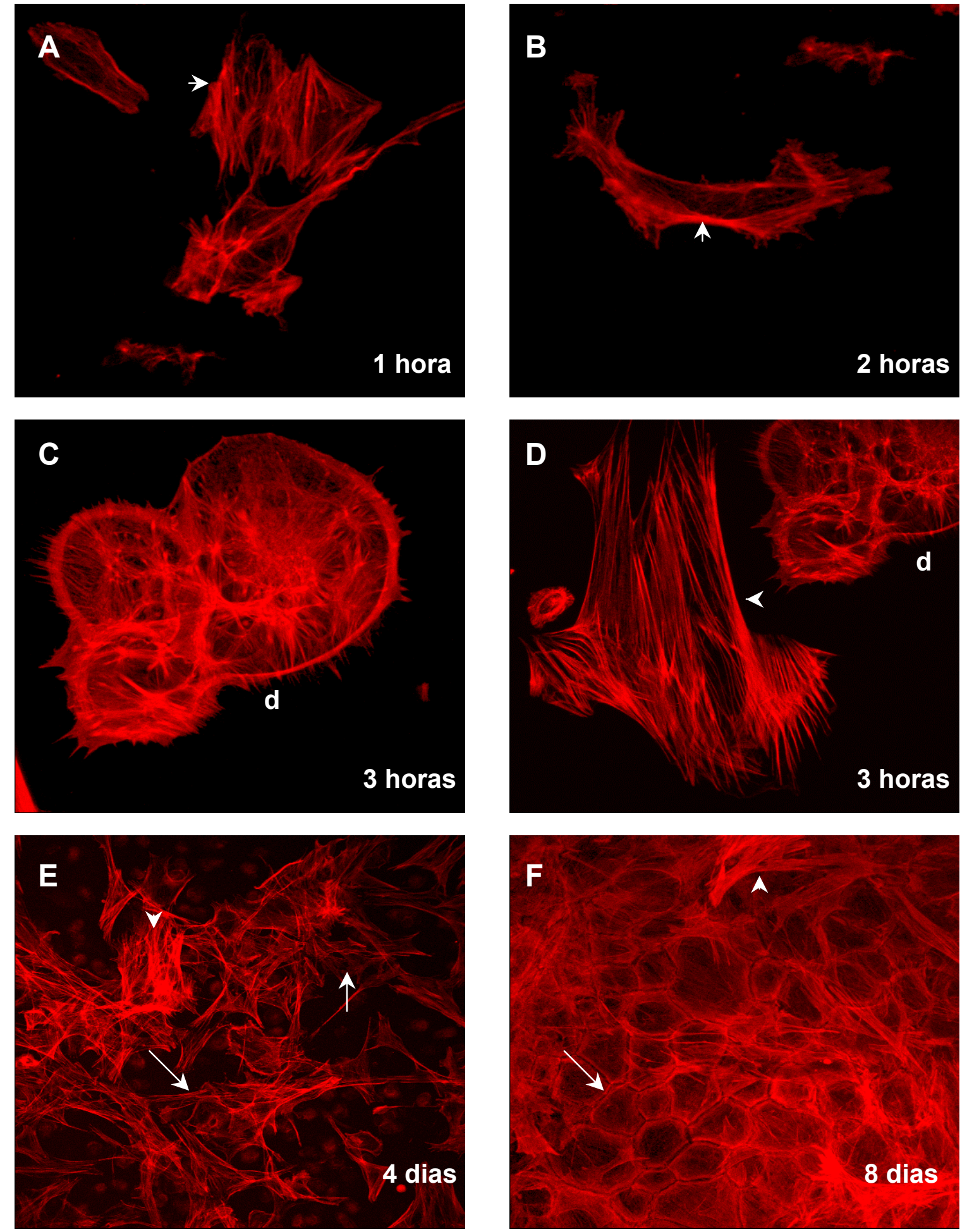

Figura 46 - Detecção da morfologia celular através do uso da faloidina-TRITC para observar a actina filamentosa característico de cada tipo celular. A, B C e D mostram células cultivadas diretamente sobre lâminas de vidro sem a adição de matrigel:colágeno em diferentes tempos de cultura. $\mathrm{E}$ e $\mathrm{F}$ mostram células cultivadas sobre a matriz extracelular aos 4 e 8 dias de cultivo. Aos 8 dias de cultivo podemos verificar que os fibroblastos não se proliferam na presença de APTII mais KGF $10 \mu \mathrm{g} / \mathrm{ml}$. As cabeças de setas indicam fibroblastos e as setas indicam os pneumócitos do tipo II. $\mathrm{d}=$ desconhecido 

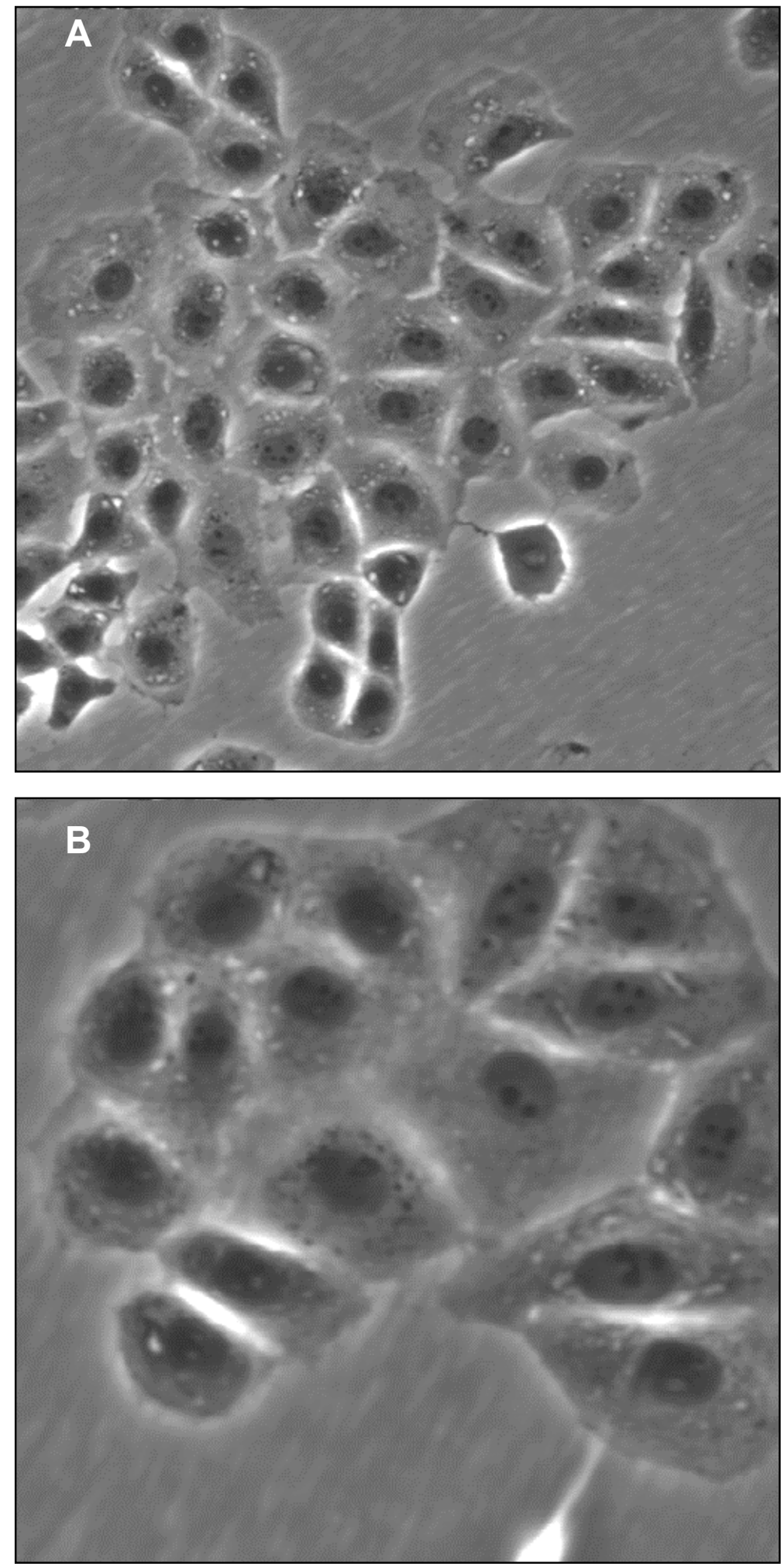

Figura 47 - Células IAR20 cultivadas em DMEM sem adição de KGF documentadas após 4 dias de cultura. As morfologias poligonais das células epiteliais são características 

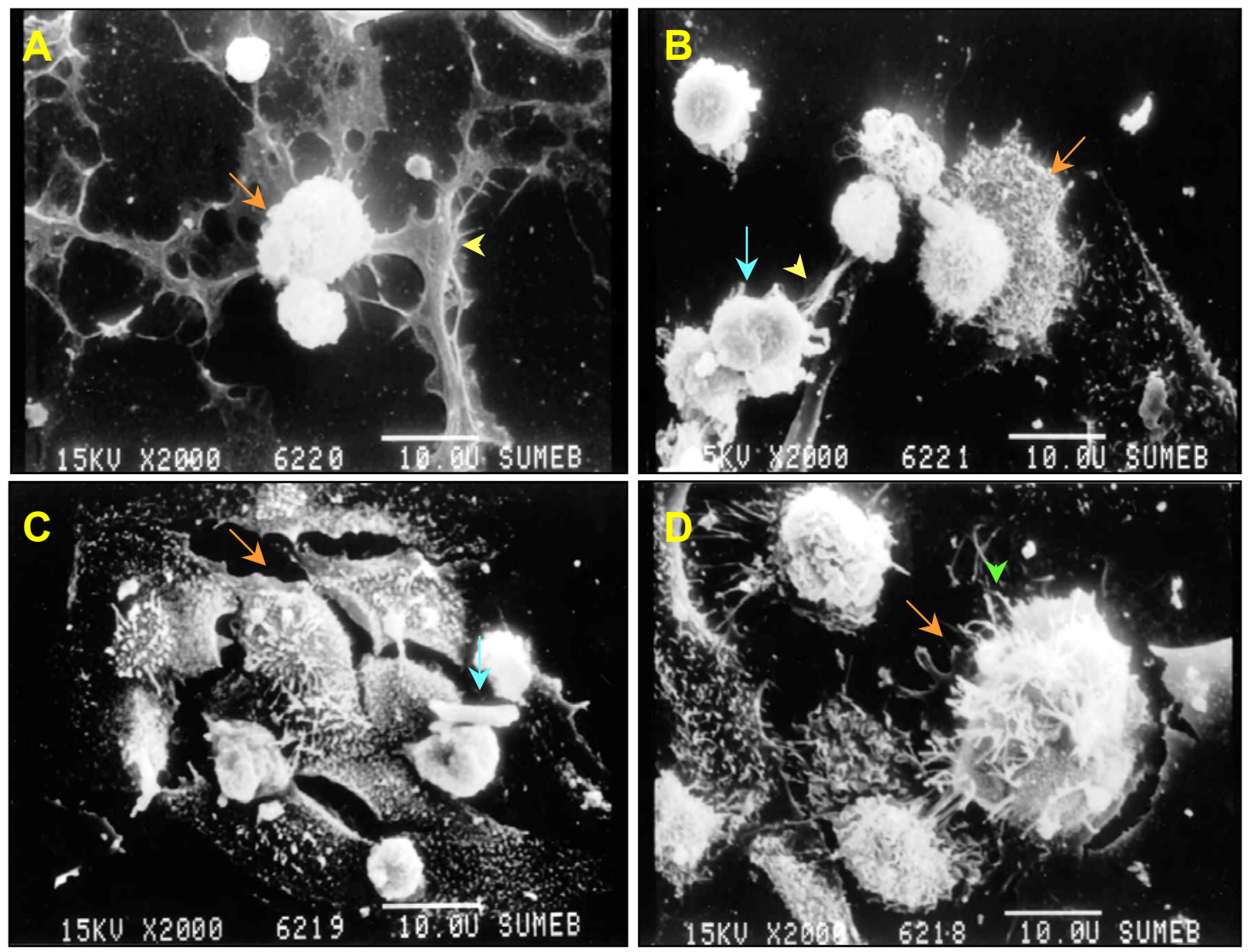

Figura 48 - APTII visualizados em microscopia eletrônica de varredura aos dois dias de cultura em DMEM acrescido de KGF. Em A, as cabeças de setas (amarelas) apontam para a matriz extracelular utilizada (Matrigel). Em A, B, C e D, as flechas (laranjas) apontam para os pneumócitos se ligando a matriz extracelular. As hemácias restantes também podem ser observadas (seta azul) em B e C. As microvilosidades características dos pnemócitos do tipo II também são visíveis (cabeça de seta verde) em $\mathbf{D}$ 


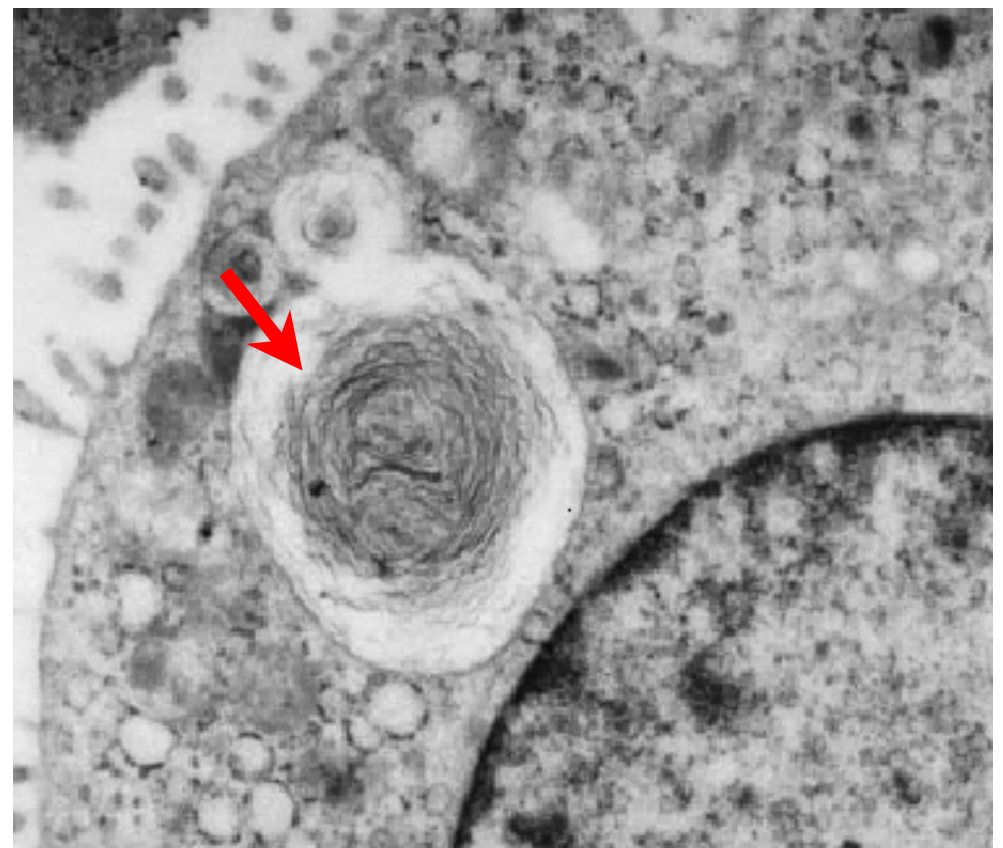

Figura 49 - Microscopia eletrônica enidenciando corpo lamelar em APTII em cultura primária de 2 dias, as células foram cultivadas em DEMEM10 acrescidas de KGF. A seta aponta para o corpo lamelar. $\times 25600$ 


\subsubsection{Expressão de conexinas nas APTII em cultura primária}

\subsubsection{Conexina 26}

Os APTIls em condições de cultura primária foram avaliadas quanto à expressão das conexinas 26, 32, 43 e 46 (Figuras 50, 51, 52 e 53). A marcação foi efetuada em células isoladas de camundongos machos e fêmeas com idade variando de 6 a 10 semanas. In vivo nós observamos que as fêmeas são mais resistentes a carcinogênese pulmonar induzida pela uretana. Assim, este experimento foi idealizado com o objetivo de encontrar uma resposta a essa incógnita e também avaliar as alterações que ocorrem nos APTII provenientes dos camundongos $\mathrm{C} \times 43^{+/-}$quando comparados aos APTII derivados dos camundongos $\mathrm{Cx} 43^{+/+}$. A imunomarcação da connexina 26 (Figura 50) revelou uma provável marcação para esta conexina na região citoplasmática nos APTII provenientes dos camundongos $\mathrm{C}_{4} 43^{+/-}$(Figuras $50 \mathrm{~B}$ e D). O mesmo resultado foi encontrado tanto para os machos quanto para as fêmeas nestas condições. 
Controle
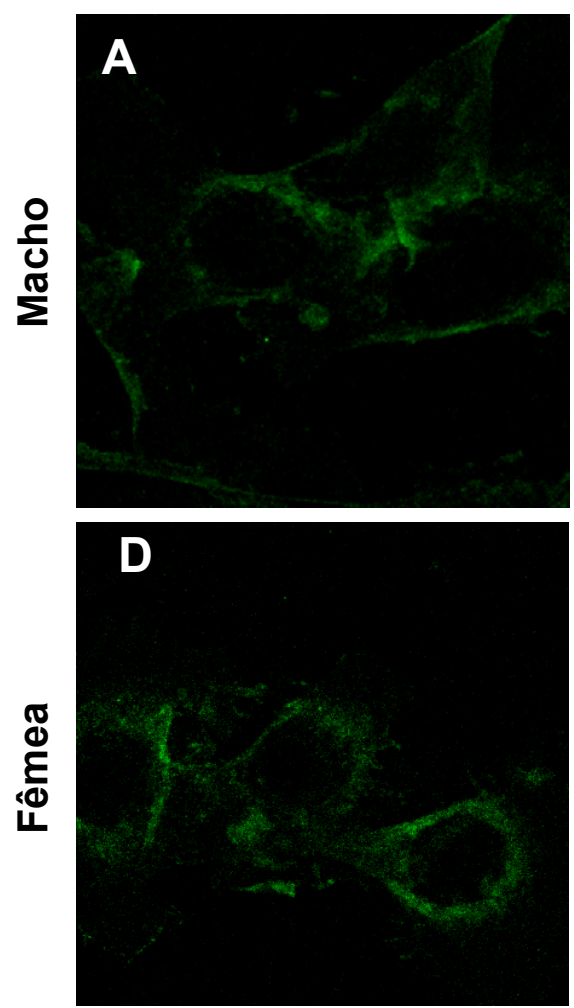

Cx43 $3^{+/+}$
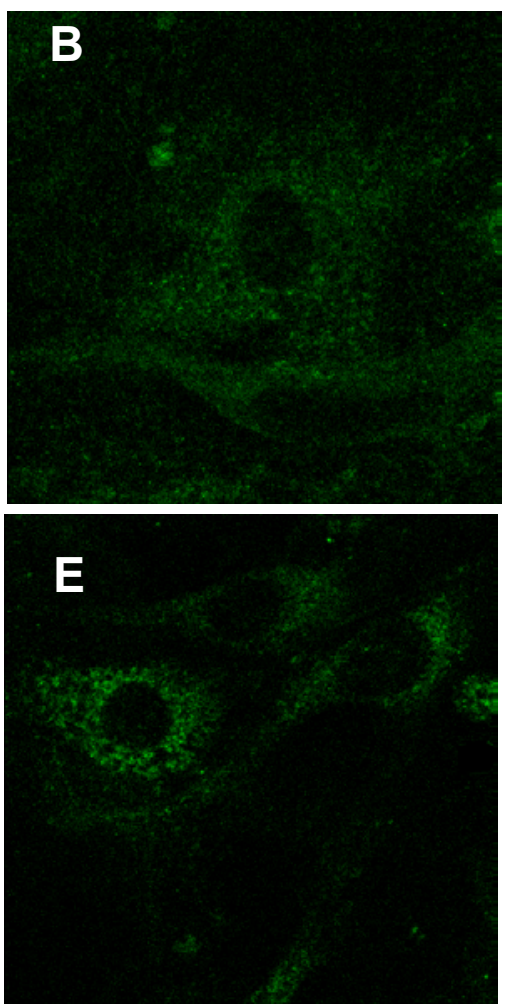

Cx43
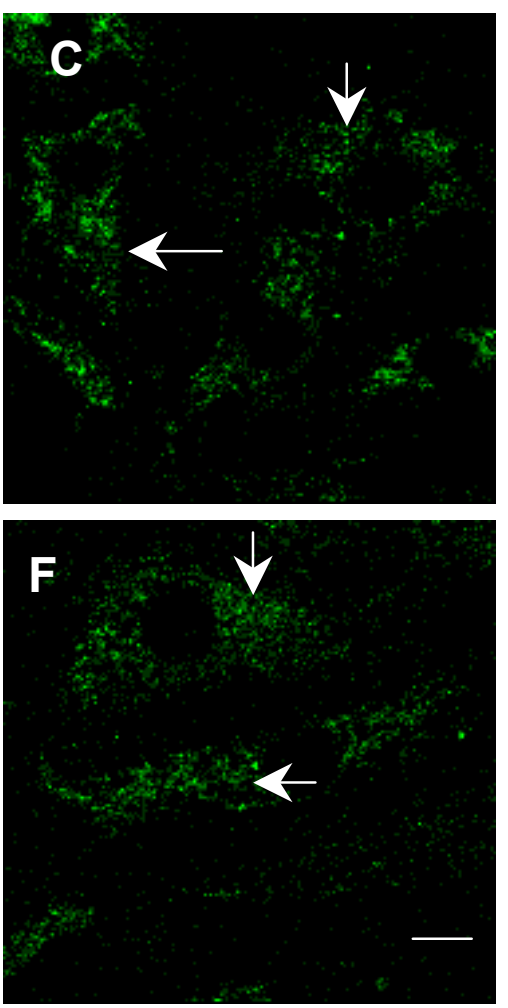

Figura 50 - Expressão da conexina 26 pelas APTII no dia 4 de cultura. As células foram cultivadas como descrito no Material e Métodos e imunomarcadas com anticorpo anticonexina 26 monoclonal (Zymed) por 1 hora à temperatura ambiente. Foram utilizados camundongos machos (B e C) e fêmeas (E e F) de 6 a 10 semanas de idade. Os controles negativos também são apresentados (A e D). As setas apontam para a conexina marcada pelo anticorpo. Barra $=10 \mu \mathrm{m}$ 


\subsubsection{Conexina 32}

Nós não fomos capazes de identificar qualquer marcação para a conexina 32 em cultura de células provenientes dos camundongos machos, tanto nos heterozigotos quanto nos Cx43+/+ (Figuras 51 B e C). Por outro lado, nós detectamos uma marcação extremamente forte, aparentemente citoplasmática, para as fêmeas Cx $43^{+/-}$(Figura $\left.51 \mathrm{~F}\right)$.
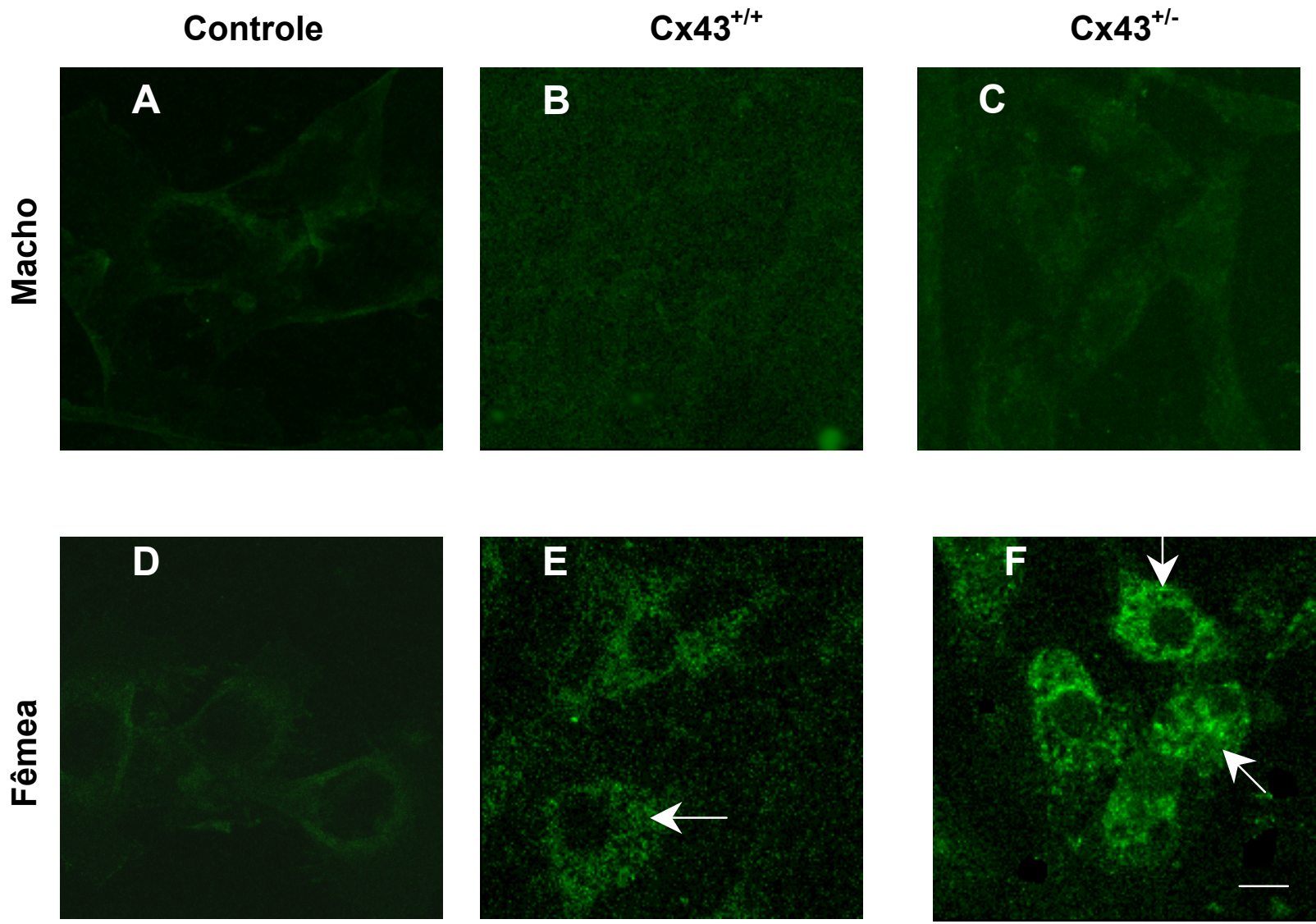

Figura 51 - Expressão da conexina 32 pelas células alveolares epiteliais do tipo II no dia 4 de cultura. As células foram cultivadas como descrito no Material e Métodos e imunomarcadas com anticorpo anticonexina 32 monoclonal (Zymed) por 1 hora a temperatura ambiente. Foram utilizados camundongos machos (B e $\mathbf{C}$ ) e fêmeas (E e F) de 6 a 10 semanas de idade. Os controles negativos também são apresentados (A e D). As setas apontam para a conexina marcada pelo anticorpo. Barra $=10 \mu \mathrm{m}$ 


\subsubsection{Conexina 43}

Para a marcação da conexina 43 nós utilizamos anticorpos monoclonal (Zymed) diluído em PBS. Nós observamos uma forte marcação na membrana e no citoplasma destas células. A marcação observada nos camundongos $\mathrm{C} \times 43^{+/-}$ foi visivelmente mais fraca que aquela dos camundongos $\mathrm{C} \times 43^{+/+}$(Figura $52 \mathrm{~B}$ e C). Nós não observamos qualquer diferença entre os APTII derivados dos camundongos machos e fêmeas para esta conexina (Figura $52 \mathrm{E}$ e F). A presença de placas de conexinas presentes na área de contato entre as células é evidente (setas na Figura 52).
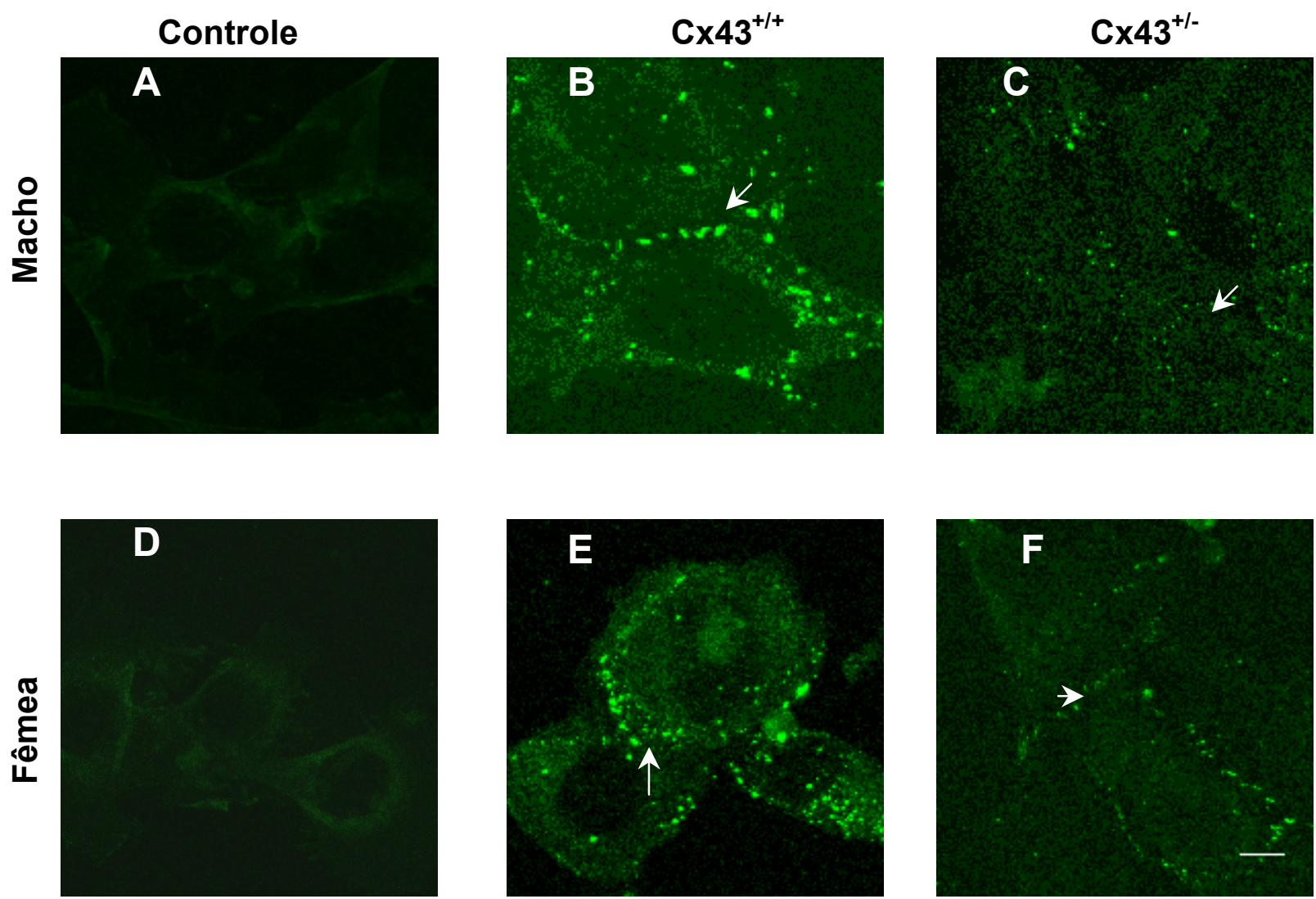

Figura 52 - Expressão da conexina 43 pelas células alveolares epiteliais do tipo II no dia 4 de cultura. As células foram cultivadas como descrito no Material e Métodos e imunomarcadas com anticorpo anticonexina 43 monoclonal (Zymed) por 1 hora à temperatura ambiente. Foram utilizados camundongos machos (B e C) e fêmeas (E e F) de 6 a 10 semanas de idade. Os controles negativos também são apresentados (A e D). As setas apontam para a conexina marcada pelo anticorpo. Barra $=10 \mu \mathrm{m}$ 


\subsubsection{Conexina 46}

Os anticorpos utilizados para a identificação da presença desta conexina foram cedidos pelo Dr. Koval (Escola de Medicina da Universidade da Pensilvânia, Filadélfia, EUA). Unıa das características desta conexina é o fato dela ser constantemente encontrada no citoplasma da maioria das células já estudadas. Neste estudo, com os APTII isolados, a marcação se mostrou aparentemente citoplasmática para os camundongos machos $\mathrm{Cx} 43^{+/+}$(Figura 53 B). A marcação se mostrou muito forte para os camundongos $\mathrm{C} \times 43^{+/-}$, com placas, mas é impossível concluir se a marcação está restrita apenas à membrana ou se é citoplasmática também (Figura $53 \mathrm{C}$ ). Para as fêmeas nós concluímos que a situação observada é a mesma tanto para os camundongos $\mathrm{Cx}_{43^{+/+}}$quanto para os $\mathrm{Cx} 43^{+/-}$(Figuras $53 \mathrm{E} \mathrm{e} \mathrm{F}$ ). 

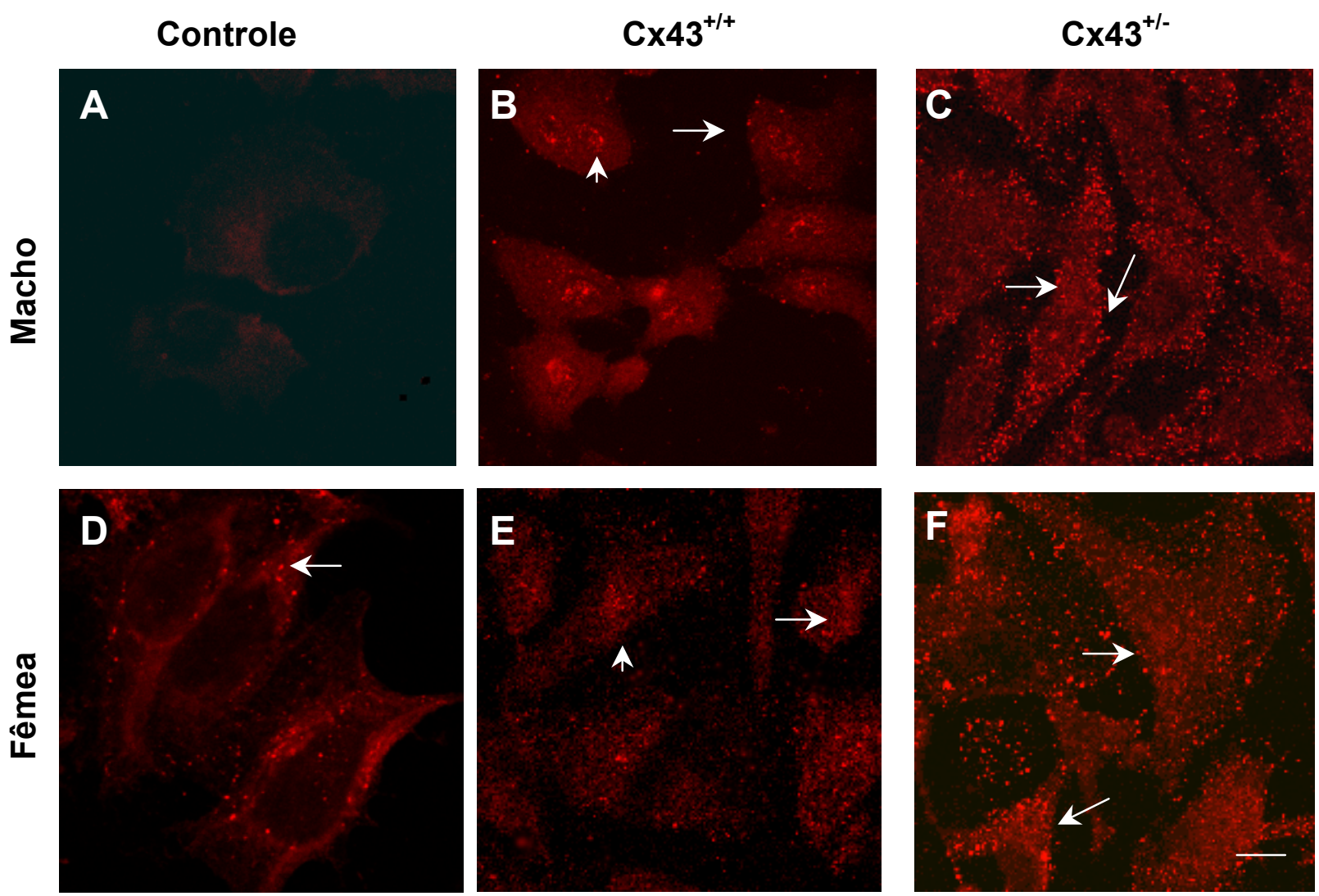

Figura 53 - Expressão da conexina 46 pelas células alveolares epiteliais do tipo II no dia 4 de cultura. As células foram cultivadas como descrito no Material e Métodos e imunomarcadas com anticorpo anticonexina 46 monoclonal (Zymed) por 1 hora à temperatura ambiente. Foram utilizados camundongos machos (B e C) e fêmeas (E e F) de 6 a 10 semanas de idade. O controle negativo e o positivo (HeLa transfectada com o gene da Cx46) também são apresentados (A e $\mathbf{D}$, respectivamente). As setas apontam para a conexina marcada pelo anticorpo. Barra $=10 \mu \mathrm{m}$ 


\subsubsection{Localização das conexinas $26,32,43$ e 46 in vivo utilizando a técnica de imunofluorescência}

\subsubsection{Camundongos $\mathrm{Cx} 43^{+/+}$}

Numa tentativa dos APTII de se diferenciar em pneumócitos do tipo I, as Cx26, 32, 43 e 46 sofrem modificações no padrão de expressão com o passar do tempo em cultura (KOVAL, 2002). Nós utilizamos a técnica de imunofluorescência para determinar se estas conexinas também são expressas pelos APTII in situ (Figura 54). A Cx26 foi detectada e se mostrou pontual e expressa de maneira irregular para os camundongos machos (Figura 54 D) e mais heterogêneos nas fêmeas (Figura 54 B). A marcação foi levemente citoplasmática e específica e mais acentuada nos machos (Figura $54 \mathrm{C}$ ).

Para a Cx32 nós não observamos marcação característica de placas na membrana das células. A coloração foi homogênea, citoplasmática e idêntica quando comparada entre os machos e as fêmeas (Figuras 54 E e F).

Quando foi efetuada a marcação para a Cx43, nós evidenciamos uma marcação pontual para esta conexina (Figuras 54 H e l). A coloração citoplasmática estava presente mas, com menos intensidade que a observada para as demais conexinas. Não houve diferença entre machos e fêmeas.

A marcação foi pontual para algumas células marcadas com anticorpos contra a Cx46. Por outro lado, a marcação foi principalmente citoplasmática e heterogênea. Alguns pontos localizados entre as células também podem ser identificados. Nós também não evidenciamos qualquer diferença entre machos e fêmeas quanto a esta conexina (Figuras $54 \mathrm{~L}$ e M). 

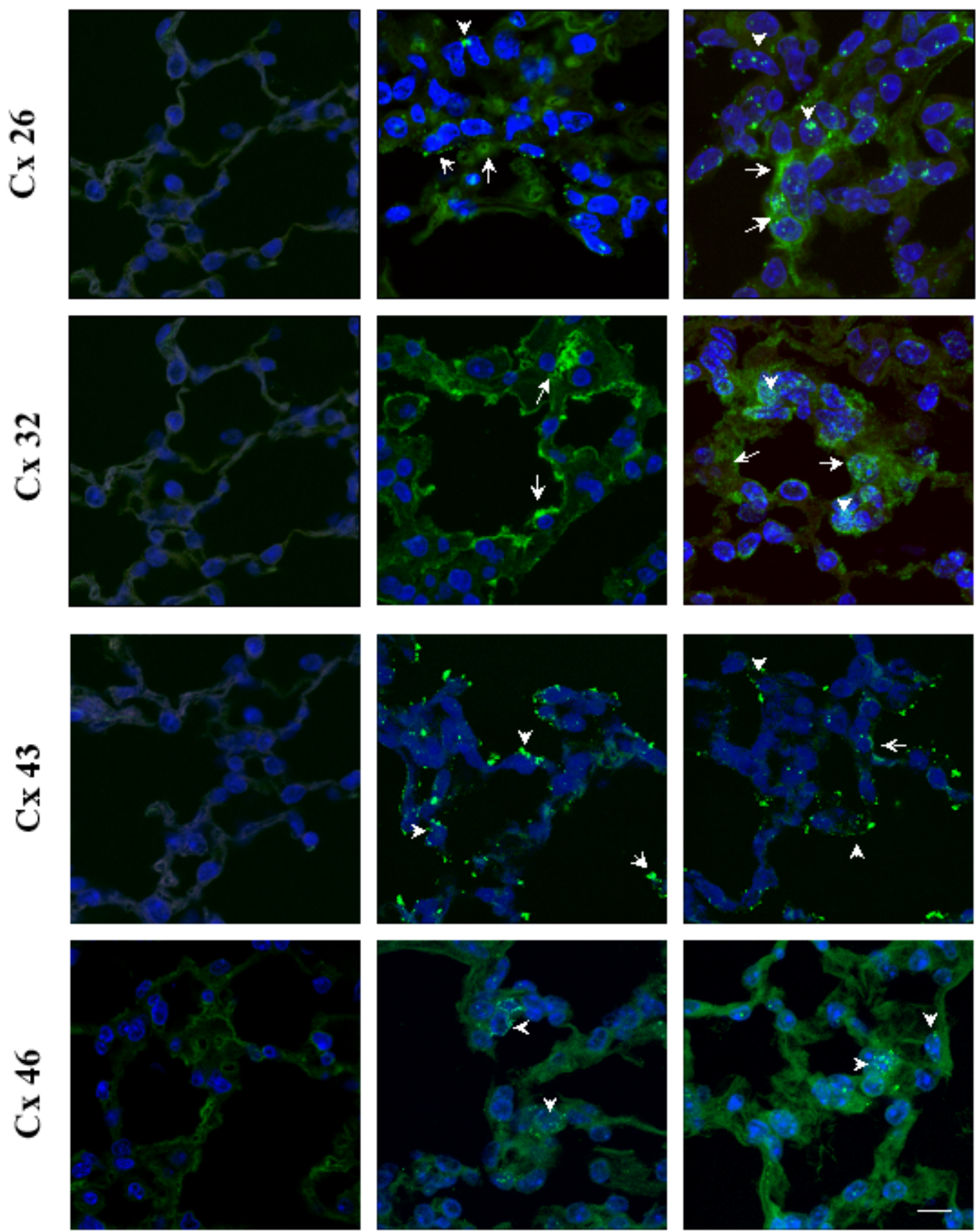

\section{Controle negativo}

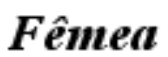

\section{Macho}

Figura 54 - Expressão das conexinas 26, 32, 43 e 46 visualizadas no pulmão de camundongos $\mathrm{C} \times 43^{+/+}$. Os pulmões foram obtidos de camundongos de 10 semanas de idade, foram processados e seccionados como descrito no "material e métodos". As seções foram imunomarcadas com anticorpos monoclonais para as conexinas 26 (B e C), 32 (E e F) e $43(\mathrm{H} \mathrm{e} \mathrm{I})$ e policlonal para a conexina 46 ( $\mathrm{L}$ e M). Controle negativo (A, D, G e J). As cabeças de seta apontam para a marcação citoplasmática e as setas para a marcação nas membranas. Núcleo corado com TOPRO3. Barra $10 \mu \mathrm{m}$ 


\subsubsection{Camundongos $\mathrm{Cx} 43^{+/-}$}

Quando a imunomarcação foi efetuada para a Cx26 nos camundongos $\mathrm{C} \times 43^{+/-}$, a marcação pontual praticamente deixou de existir (Figura 55). A coloração foi aparentemente específica no citoplasma e heterogênea, sobretudo para as fêmeas (Figura 55 B). Nos APTII dos camundongos machos, apenas algumas células se mostraram marcadas (Figura 55 C).

Para a Cx32 nós também não visualizamos marcação pontual, exceto para as fêmeas onde se observa raros locais com placas (Figura 55 E). Caso contrário, a marcação é homogênea e idêntica entre machos e fêmeas e aparentemente citoplasmática (Figuras 55 E e F).

A marcação da Cx43 mostrou-se difusa, aparentemente citoplasmática e idêntica entre machos e fêmeas (Figuras $55 \mathrm{H}$ e I). Pontos ou placas foram raramente observados.

A Cx46 apresentou marcação granular, possivelmente citoplasmática em algumas células, mas não em todas. Pouca diferença pôde ser observada entre machos e fêmeas. Talvez, ligeiramente mais intensa nas fêmeas (Figuras $55 \mathrm{~L}$ e M). As figuras 56 e 57 são apenas uma comparação para facilitar a visualização entre machos e/ou fêmeas do mesmo genótipo. 

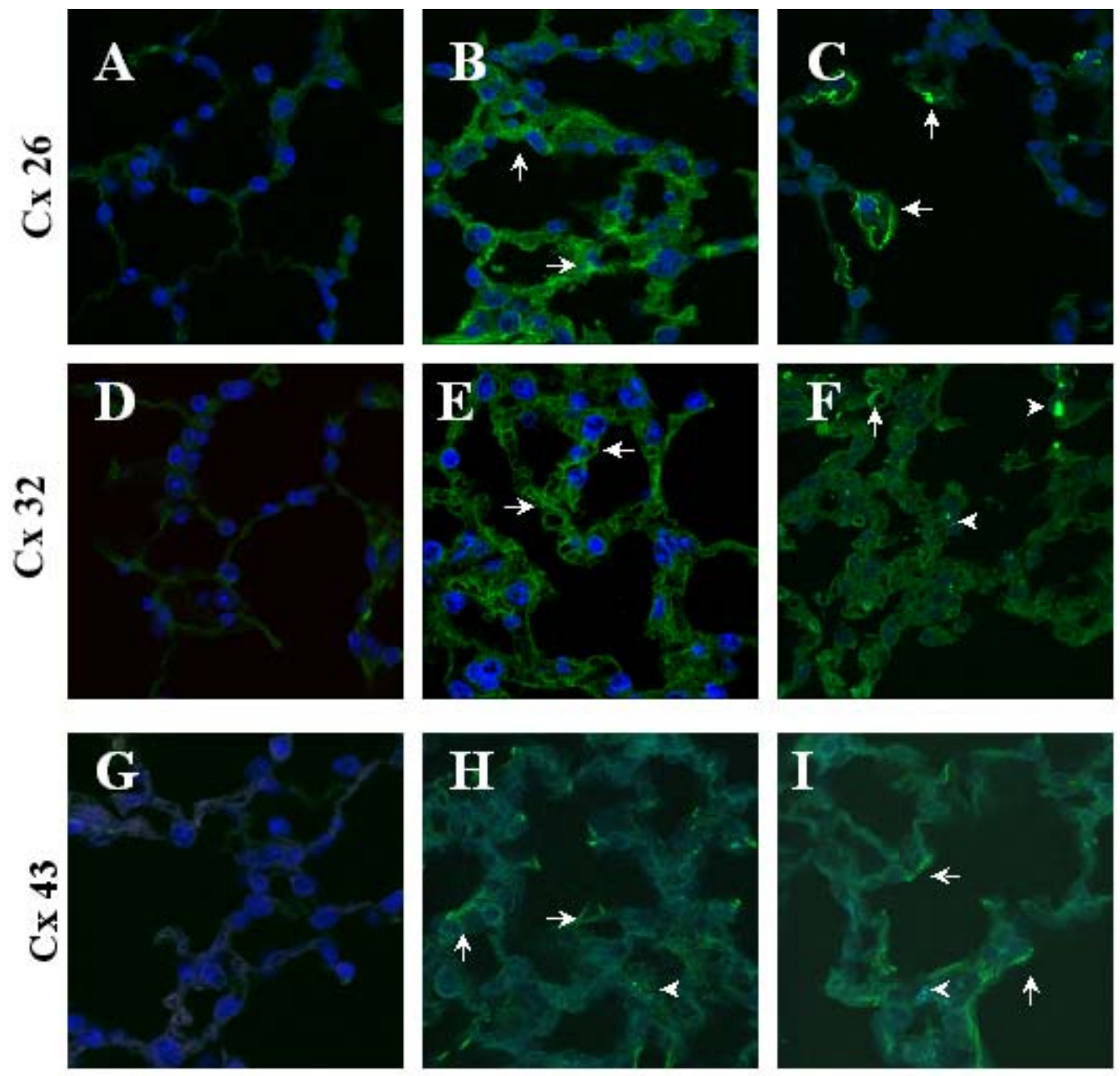

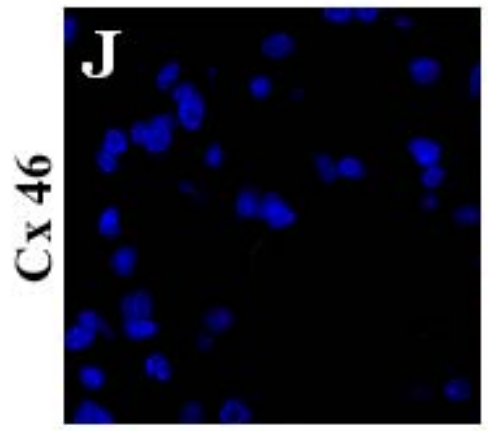

Controle negativo

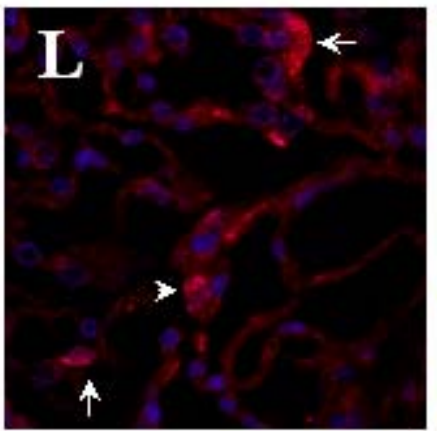

Fêmea

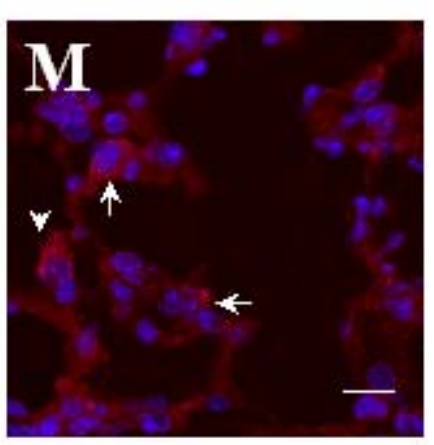

Macho

Figura 55 - Expressão das conexinas 26, 32, 43 e 46 visualizadas no pulmão de camundongos $\mathrm{C} \times 43^{+/-}$. Os pulmões foram obtidos de camundongos de 10 semanas de idade, foram processados e seccionados como descrito no "material e métodos". As seções foram imunomarcadas com anticorpos monoclonais para as conexinas 26 (B e $C$ ), $32(\mathrm{E}$ e $\mathrm{F})$ e 43 ( $\mathrm{H} \mathrm{e} \mathrm{I}$ ) e policlonal para a conexina 46 ( $\mathrm{L}$ e $\mathrm{M})$. Controle negativo ( $\mathrm{A}$, $\mathrm{D}, \mathrm{G}$ e J). As cabeças de setas apontam para a marcação citoplasmática e as setas para a marcação nas membranas. Núcleo corado com TOPRO3. Barra $10 \mu \mathrm{m}$ 
Wildype
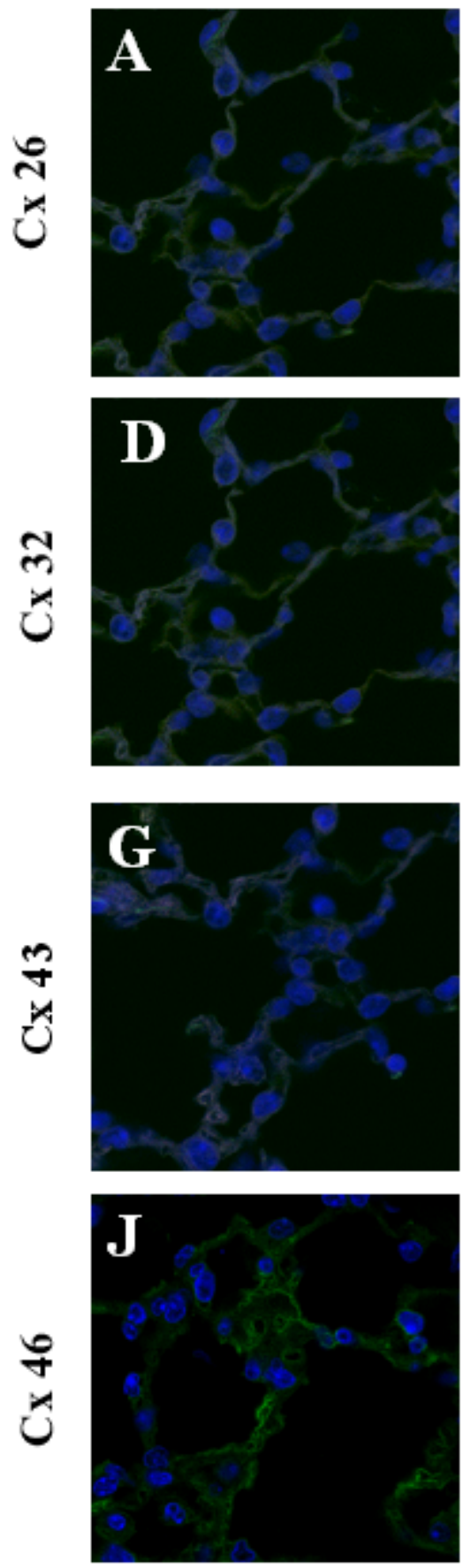

Controle negativo
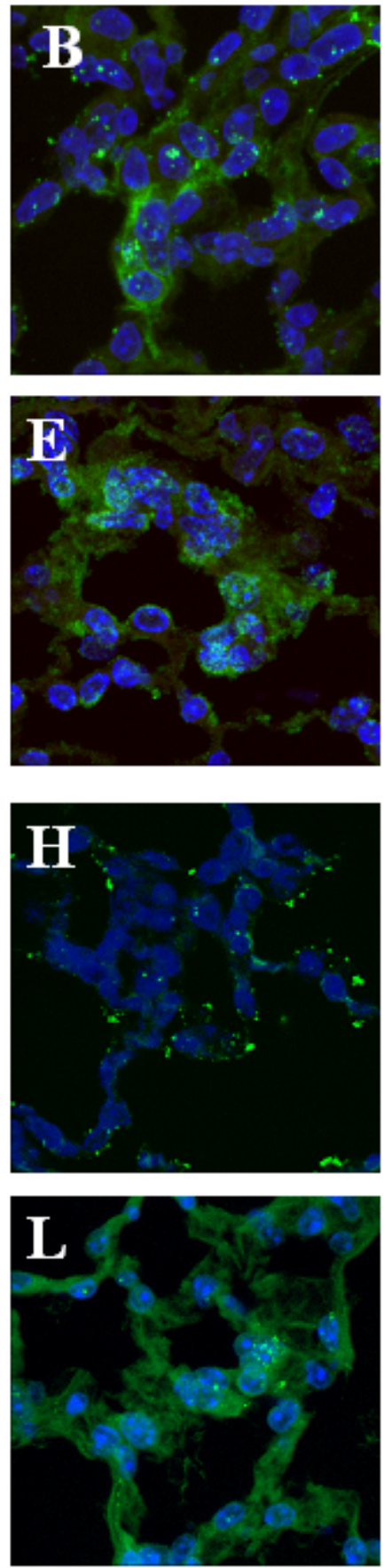
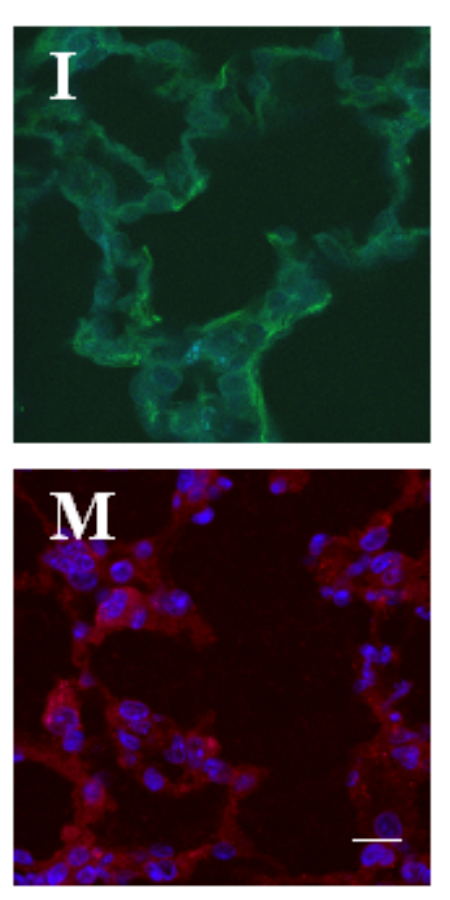

Heterozigoto
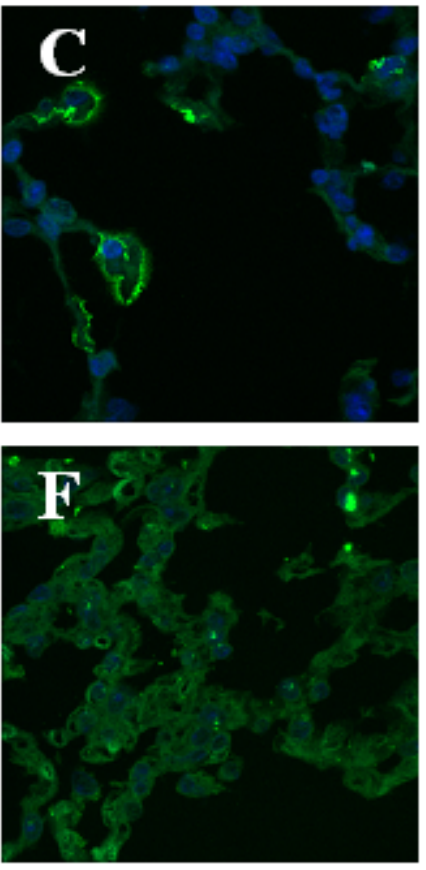

Figura 56 - Expressão das conexinas 26, 32, 43 e 46 no pulmão de camundongos machos Cx43 ${ }^{+/-}$ e $\mathrm{C} \times 43^{+/+}$. Os pulmões foram obtidos de camundongos de 10 semanas de idade, foram processados e seccionados como descrito no "material e métodos". As seções foram imunomarcadas com anticorpos monoclonais para as conexinas 26 (B e C), 32 $(\mathrm{E}$ e $\mathrm{F})$ e 43 ( $\mathrm{H} \mathrm{e} \mathrm{I}$ ) e policlonal para a conexina 46 ( $\mathrm{L}$ e $\mathrm{M})$. Controle negativo (A, D, G e J). Núcleo corado com TOPRO3. Barra $10 \mu \mathrm{m}$ 
Wildype
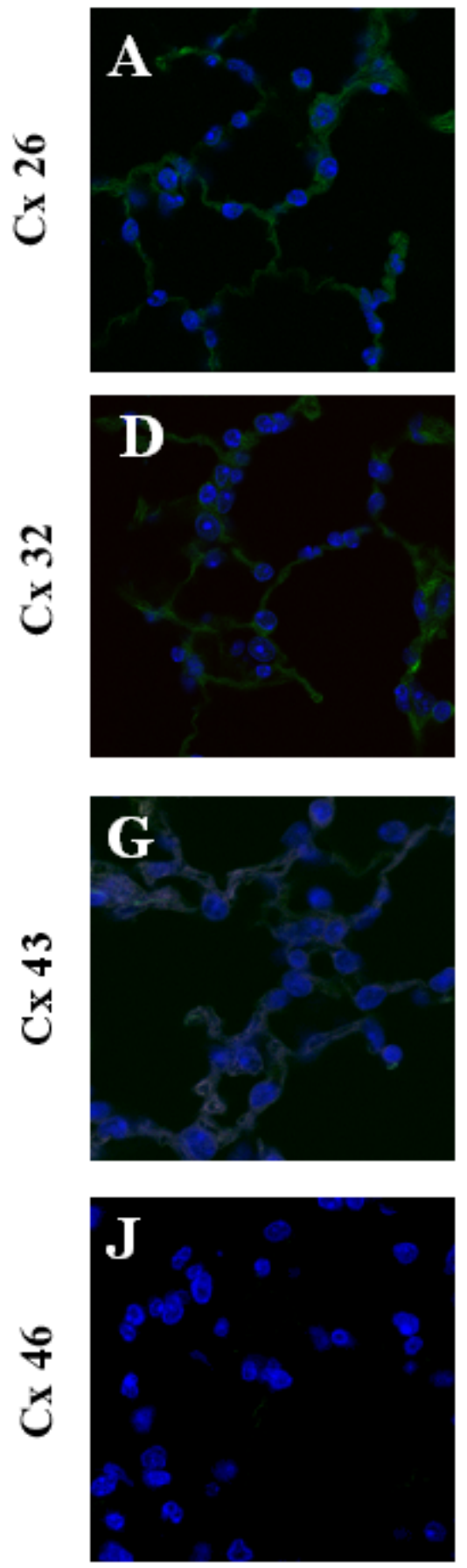

Controle negativo
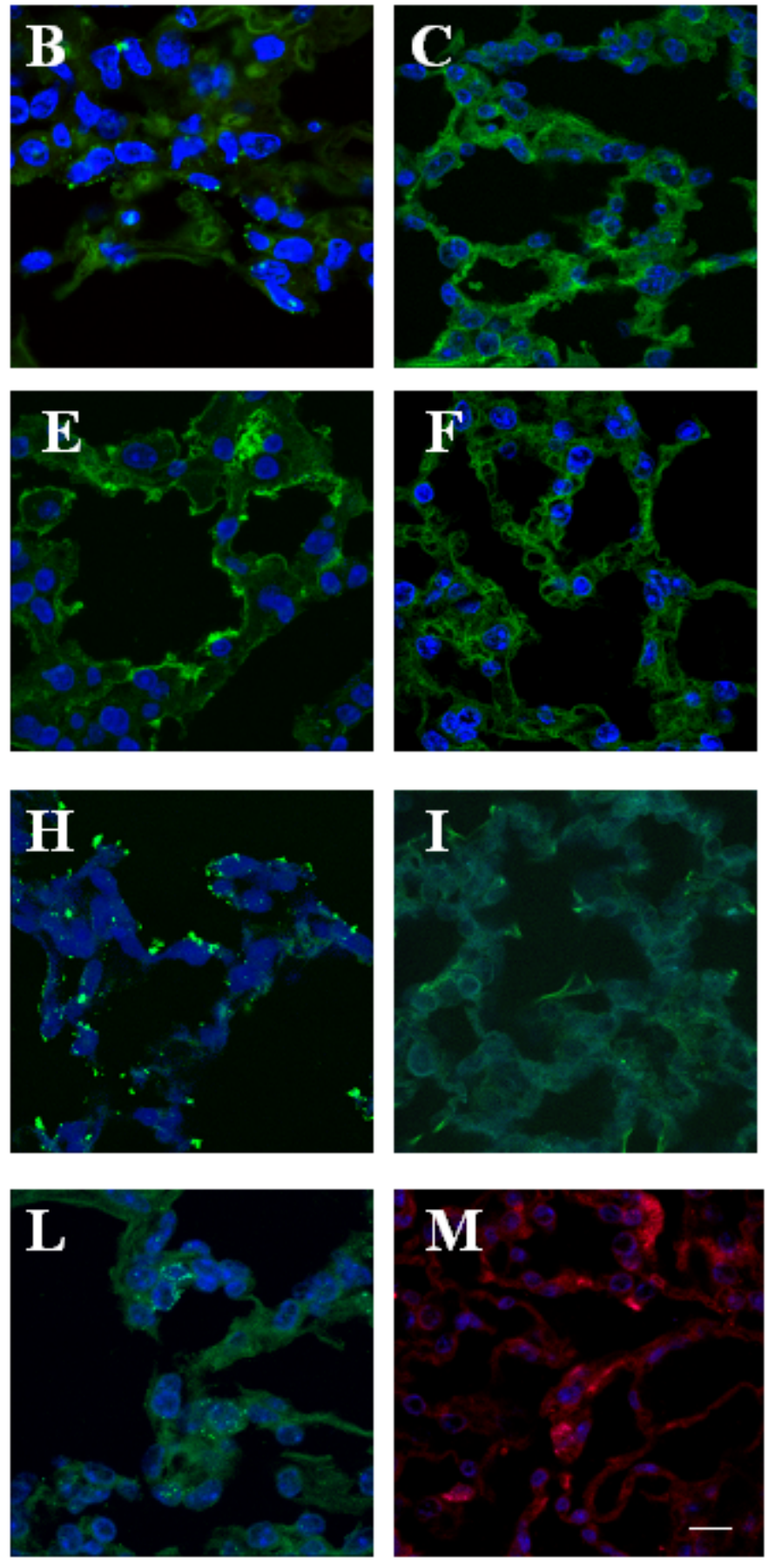

Fêmea
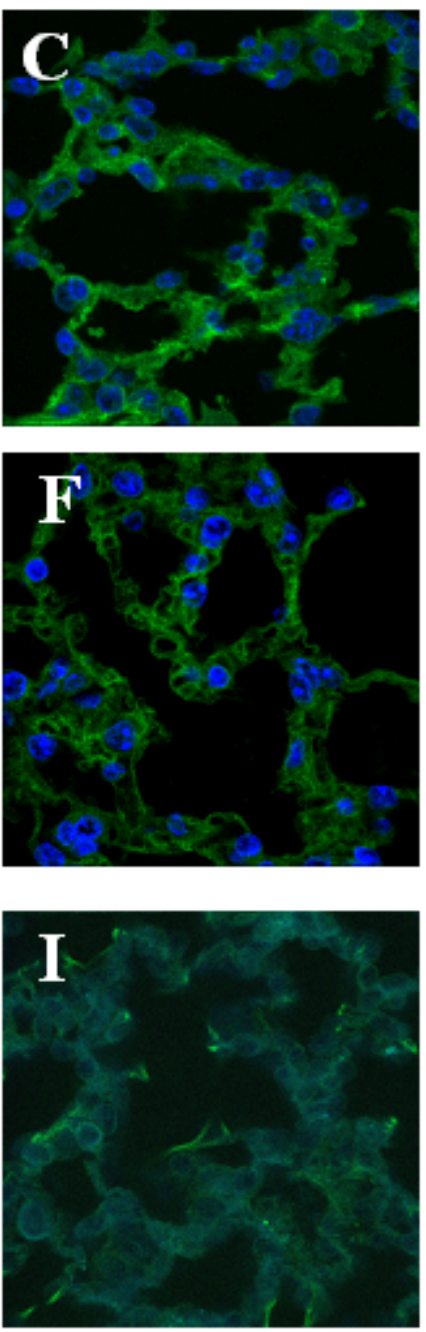

Heterozigoto

Figura 57 - Expressão das conexinas 26, 32, 43 e 46 visualizadas no pulmão de camundongos
fêmeas $\mathrm{C} \times 43^{+/-}$e $\mathrm{Cx} 43^{+/+}$. Os pulmões foram obtidos de camundongos de 10 semanas de idade, foram processados e seccionados como descrito no "material e métodos". As seções foram imunomarcadas com anticorpos monoclonais para as conexinas 26 ( $\mathrm{B} \mathrm{e} \mathrm{C}$ ), 32 ( $\mathrm{E} \mathrm{e} \mathrm{F}$ ) e 43 ( $\mathrm{H} \mathrm{e} \mathrm{I}$ ) e policlonal para a conexina 46 ( $\mathrm{L} \mathrm{e}$ M). Controle negativo (A, D, G e J). Núcleo corado com TOPRO3. Barra $10 \mu \mathrm{m}$ 


\subsubsection{Marcação para as Cx26, 43, 46 e APTII ao mesmo tempo}

Para a identificação dos APTII nós escolhemos utilizar o anticorpo anti-pan citoqueratina como marcador pelo fato das citoqueratinas reconhecidas por este anticorpo (citoqueratina 8 e 18) serem fortemente expressas pelas células de interesse (SCHITTNY et al., 1998; WOODCOCK-MITCHELL et al., 1990). A marcação para a citoqueratina mostrou-se discreta e limitada ao canto dos alvéolos, região onde se localizam os pneumócitos do tipo II. Quando efetuada a dupla marcação para a Cx26, tanto nos machos quanto para as fêmeas nós observamos uma superposição das imagens (Figura 58). No entanto, a superposição foi mais específica para os machos e mais homogênea para as fêmeas.

Não foi evidenciada nenhuma superposição para as fêmeas Cx43 quando a Cx43 foi utilizada (Figura 59). Nos heterozigotos nós verificamos a superposição. Nos camundongos machos, a superposição de imagens foi heterogênea nos camundongos selvagens e incompleta nos camundongos $\mathrm{Cx} 43^{+/-}$

Os camundongos machos $\mathrm{Cx}_{43^{+-}}$para a $\mathrm{Cx46}$ não apresentaram superposição de imagens, a localização foi exclusiva, ao contrário daquela observada nos camundongos $\mathrm{C} \times 43^{+/+}$. Para as fêmeas, as imagens obtidas foram idênticas, com superposição incompleta (Figura 60). 

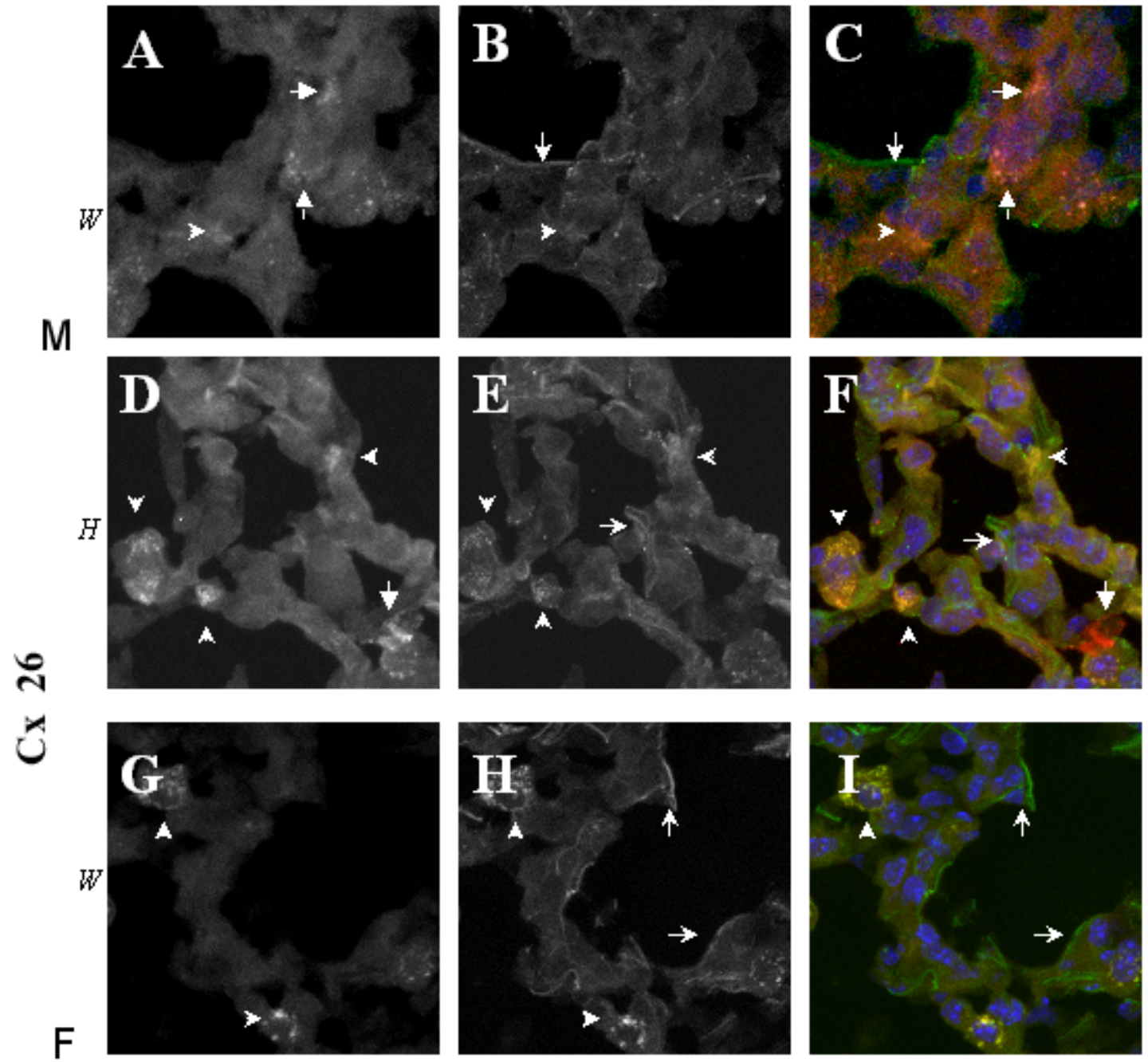

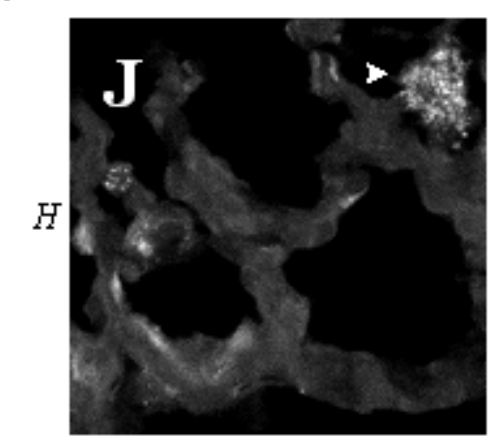

Conexina
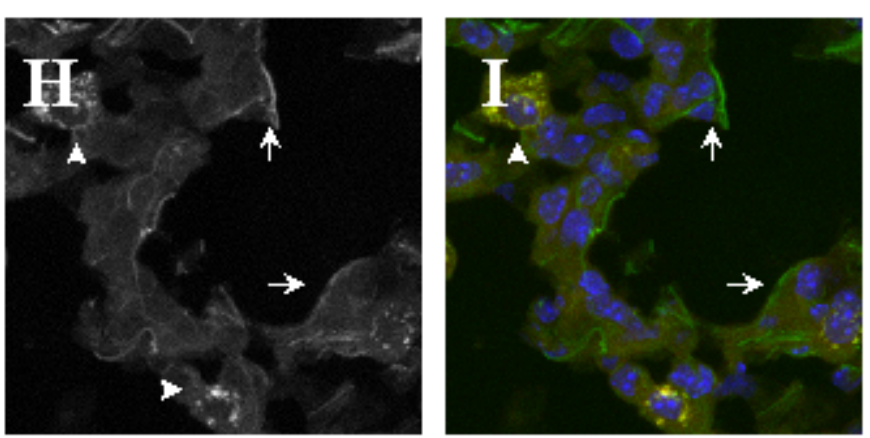

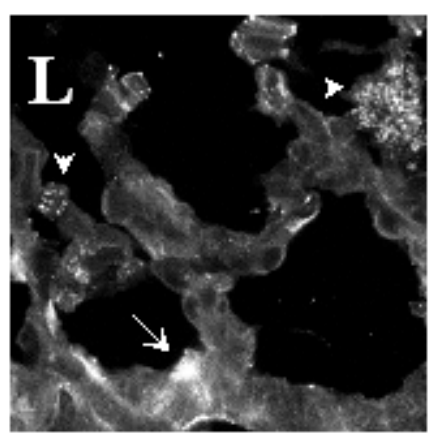

Cïtoqueratine

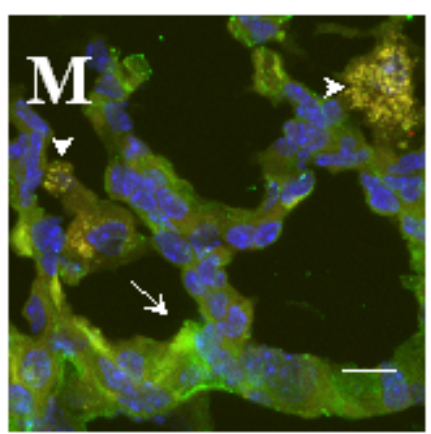

Superposição

Figura 58 - Expressão da conexina 26 nos pulmões de camundongos Cx43+/+ e Cx43+/-. As seções foram marcadas com anticorpos monoclonal antipan citoqueratina que marca preferêncialmente os APTII (B, E, H e L) e monoclonal contra Cx26 (A, D, G e J). As setas indicam as regiões de superposição de imagens e as setas apenas as regiões onde se encontram os APTII. Barra $=10 \mu \mathrm{m} . \mathrm{M}=$ macho; $\mathrm{F}=$ fêmea; $\mathrm{W}=$ wildtype; $\mathrm{H}$ $=$ heterozigoto. Núcleo corado com TOPRO3. Barra $=10 \mu \mathrm{m}$ 

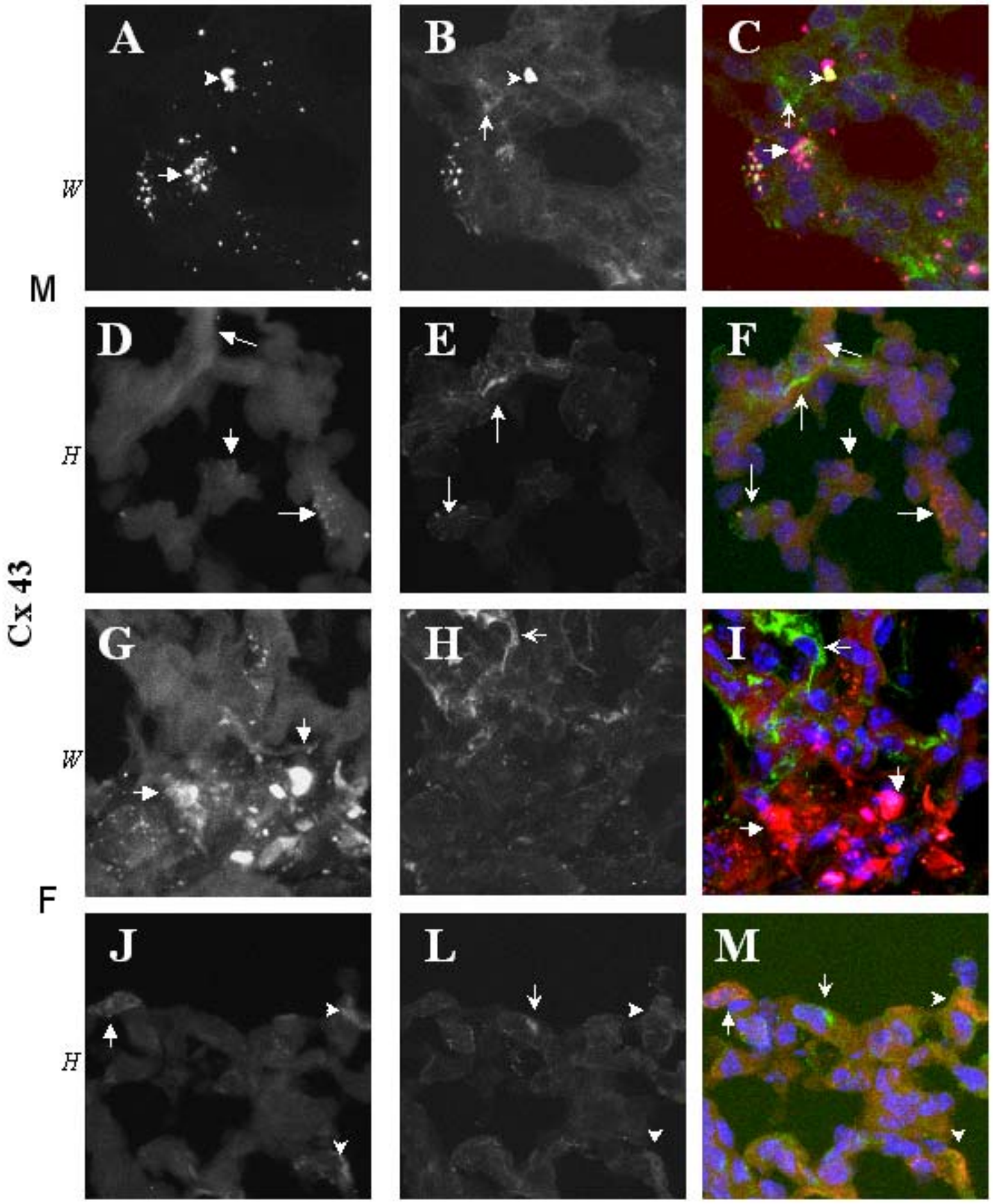

\section{Conexina}

\section{Citoqueratina}

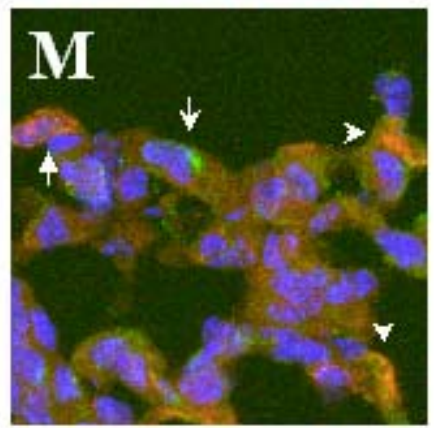

Superposição

Figura 59 - Expressão da conexina 43 nos pulmões de camundongos Cx43+/+ e Cx43+/-. As seções foram marcadas com anticorpos monoclonal antipan citoqueratina que marca preferêncialmente os APTII (B, E, H e L) e monoclonal contra Gja1 (A, D, G e J). As setas indicam as regiões de superposição de imagens e as setas apenas as regiões onde se encontram os APTII. Barra $=10 \mu \mathrm{m} . \mathrm{M}=$ macho; $\mathrm{F}=$ fêmea; $\mathrm{W}=$ wildtype; $\mathrm{H}$ $=$ heterozigoto. Núcleo corado com TOPRO3. Barra $=10 \mu \mathrm{m}$ 


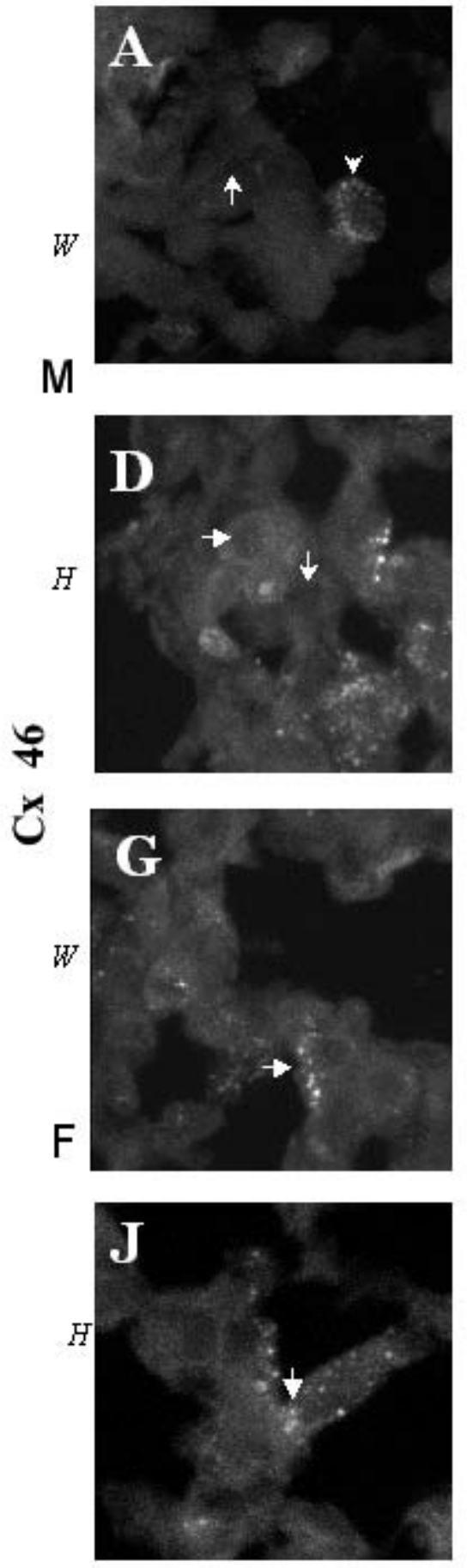

Conexina
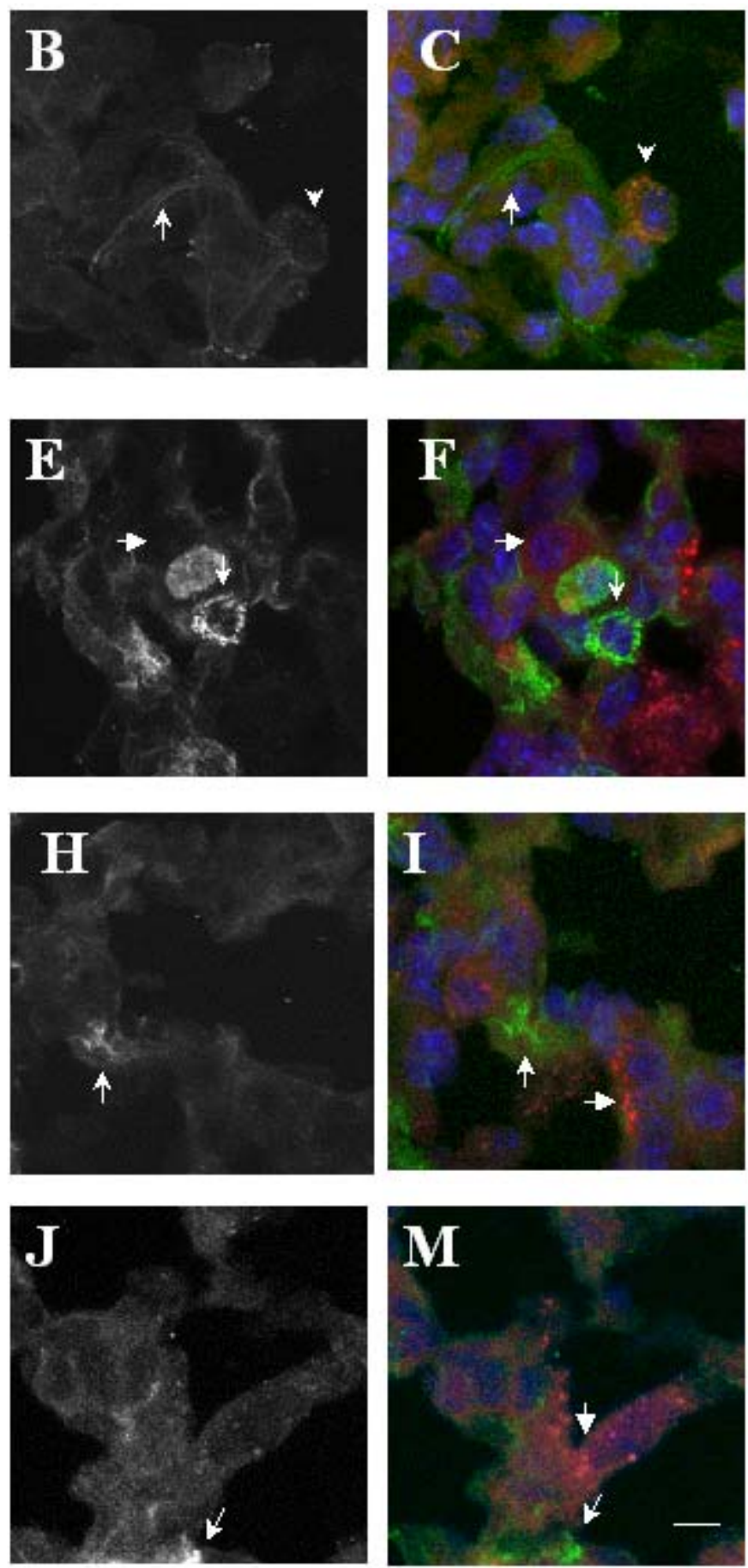

Citoqueratine

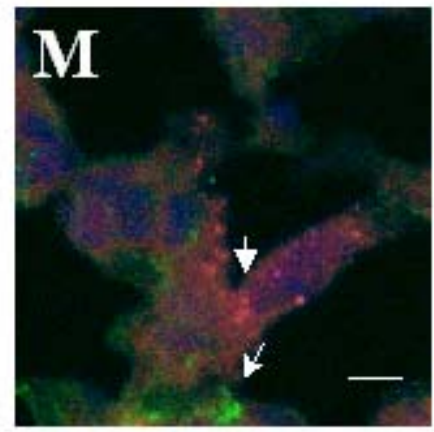

Superposição

Figura 60 - Expressão da conexina 46 nos pulmões de camundongos Cx43+/+ e Cx43+/-. As seções foram marcadas com anticorpos monoclonal antipan citoqueratina que marca preferêncialmente os APTII (B, E, H e L) e policlonal contra Gja3 (A, D, G e J). As setas indicam as regiões de superposição de imagens e as setas apontam apenas as regiões onde se encontram os $\mathrm{APTII}$. Barra $=10 \mu \mathrm{m} . \mathrm{M}=$ macho; $\mathrm{F}=$ fêmea; $\mathrm{W}=$ wildtype; $\mathrm{H}=$ heterozigoto. Núcleo corado com TOPRO3. Barra $=10 \mu \mathrm{m}$ 


\subsubsection{Análises de imunoblote das conexinas presentes nos APTII em cultura primária}

Os resultados dos imunoblotes são apresentados na figura 61. As análises de imunoblote das Cx26, 32, 43 e 46 presentes nos APTII mostrou que: (a) A marcação da Cx26, a 0 dia de incubação, é mais forte nos camundongos machos $\mathrm{C} \times 43^{+/-}$que nos machos $\mathrm{C} \times 43^{+/+}$. Esta diferença não é visível nas fêmeas. Por outro lado, o sinal desapareceu completamente nas fêmeas no quarto dia de cultura. Nos machos, o sinal ainda está presente e é idêntico entre os camundongos $\mathrm{C} \times 43^{+/+}$e $\mathrm{Cx} 43^{+/-}$;

(b) Nosso controle positivo apresentou problemas e a marcação não funcionou. Nós confirmamos isto por imunomarcação da conexina e chegamos a conclusão que a linhagem deverá ser transfectada novamente para posterior análise. Mas para os APTII, o sinal nas fêmeas, tanto à 0 e 4 dia de cultura, o sinal aparenta se mais forte nos camundongos $\mathrm{Cx} 43^{+/-}$que nos $\mathrm{Cx} 43^{+/+}$. O sinal é forte nos machos no dia 0 e não há diferença visível entre $C \times 43^{+/+}$e $C \times 43^{+/-}$. O sinal não é detectável no quarto dia de cultura;

(c) Para a Cx43 a marcação é mais fraca nos camundongos $\mathrm{C} \times 43^{+/}$ quando comparado aos camundongos $\mathrm{Cx}_{4} 3^{+/+}$. Esta diferença é mais pronunciada nas fêmeas e não há diferença entre os dias 0 e 4 de cultura;

(d) Não diferença visível entre o sinal da Cx46 para as fêmeas, Cx43 ${ }^{+/+}$e $\mathrm{C} \times 43^{+/-}$, nos dias 0 e 4 de cultura. Nos machos, o sinal é mais forte para os $\mathrm{C}_{4} 43^{+/+}$que os $\mathrm{C} \times 43^{+/-}$no dia 0 de cultura. A diferença deixa de existir no dia 4 de cultura; 
(e) O imunoblote da Cx43 também foi realizado nos tecidos, i.e, pulmão e coração como controle. O sinal é visivelmente mais fraco nos camundongos $\mathrm{Cx} 43^{+/-}$para a Cx43.

$\mathbf{A}$

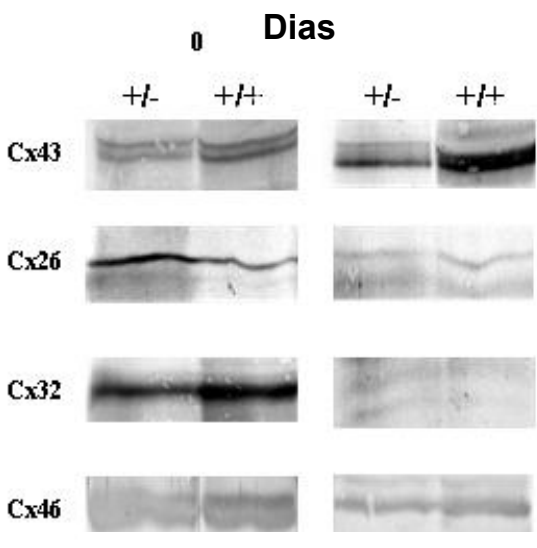

Macho

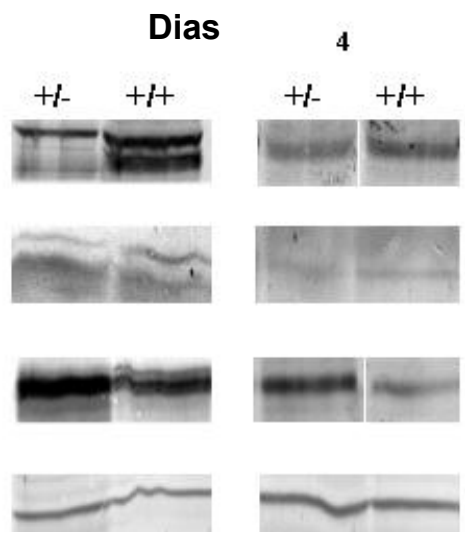

Fêmea

B

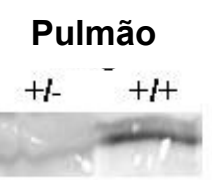

\section{Coração}

$+1-\quad+1+$

Cx43

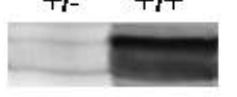

Figura 61 - Análise de imunoblote das Cx26, 32, 43 e 46 dos pneumócitos do tipo II recentemente isolados e no quarto dia de cultura. Extratos alcalinos contendo a mesma quantidade de proteínas foram analisados como descrito no "material e métodos". Dia 0 referece aos APTII recentemente isolados e os de dia 4 são os APTII em cultura. A. Imunoblote dos APTII isolados e em cultura primária. B. Imunoblote de pulmão e coração de machos e fêmeas, respectivamente 


\subsubsection{Efeito da menor expressão do gene da Cx43 sobre a comunicação das APTIls avaliadas pela técnica de scrape-loading e transferência do corante}

A técnica do scrape-loading é uma técnica relativamente simples, barata quando comparada com outras tecnologias além de muito rápida. Ela também se adequou de maneira efetiva às nossas necessidades na ocasião. Utilizando-se desta metodologia nós tivemos como objetivo avaliar a capacidade de comunicação entre os pneumócitos do tipo II isolados de camundongos heterozigotos e selvagens e compará-los quanto a sua capacidade de comunicação. Esta metodologia tem como princípio básico a utilização de um pigmento de baixo peso molecular, amarelo de lúcifer (457 Da), que pode passar pelos poros formados pelas junções do tipo gap e dessa forma podemos avaliar a capacidade de comunicação medindo a distância da região, de onde o traço foi feito, até onde o corante viajou no período de tempo determinado. Como controle foi utilizado a albumina rodamina (10000 Da), que não pode passar pelas junções do tipo gap. Ao contrário do amarelo de lúcifer que se espalha através das células que se comunicam, a albumina rodamina, se restringe à região onde as células foram injuriadas pelo bisturi. As imagens com os resultados do scrape-loading dos APTII são apresentados na figura 62. Os resultados obtidos com as células em cultura provenientes dos camundongos selvagens são apresentados nas figuras 62 A e C. Aparentemente, a capacidade de comunicação entre os pneumócitos do tipo II provenientes dos camundongos fêmeas (Figura 62 B), apresentam uma maior capacidade de comunicação que aquela observada entre os camundongos machos (Figura 62 A). A distância que o pigmento amarelo de 
lúcifer viajou quando o gene da Cx43 foi deletado é, aparentemente, maior entre os camundongos fêmeas (Figura D) quando comparados com os machos (Figura 62 B). Entretanto, é visível que a capacidade de comunicação entre os camundongos $\mathrm{Cx}_{43^{+/+}}$(Figuras $62 \mathrm{~A}$ e C) é maior quando comparamos com os camundongos $\mathrm{C} \times 43^{+/-}$(Figuras $62 \mathrm{~B}$ e D). Como esperado, a difusão do corante se dá através das junções do tipo gap formada entre as células em contato, uma vez que a albumina rodamina se manteve restrita à região onde o scrape foi produzido (traço vermelho no centro das Figuras). 
A

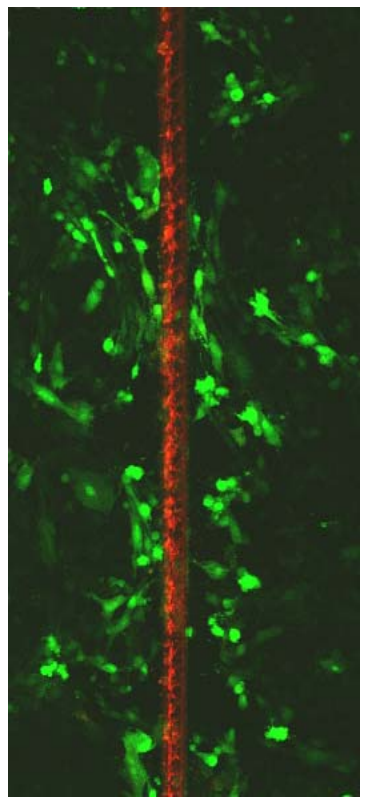

Macho

B

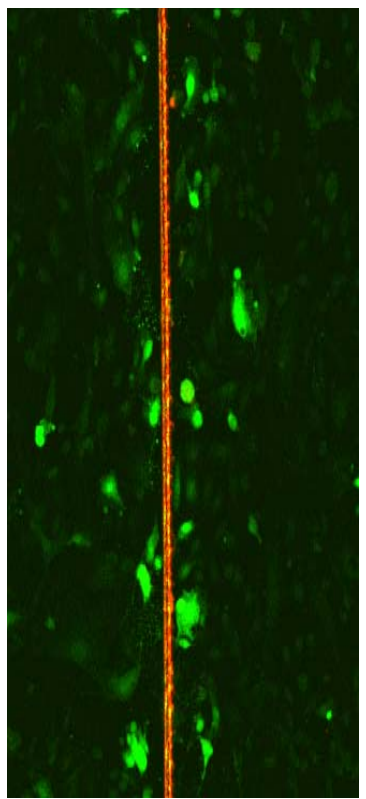

\section{Fêmea}
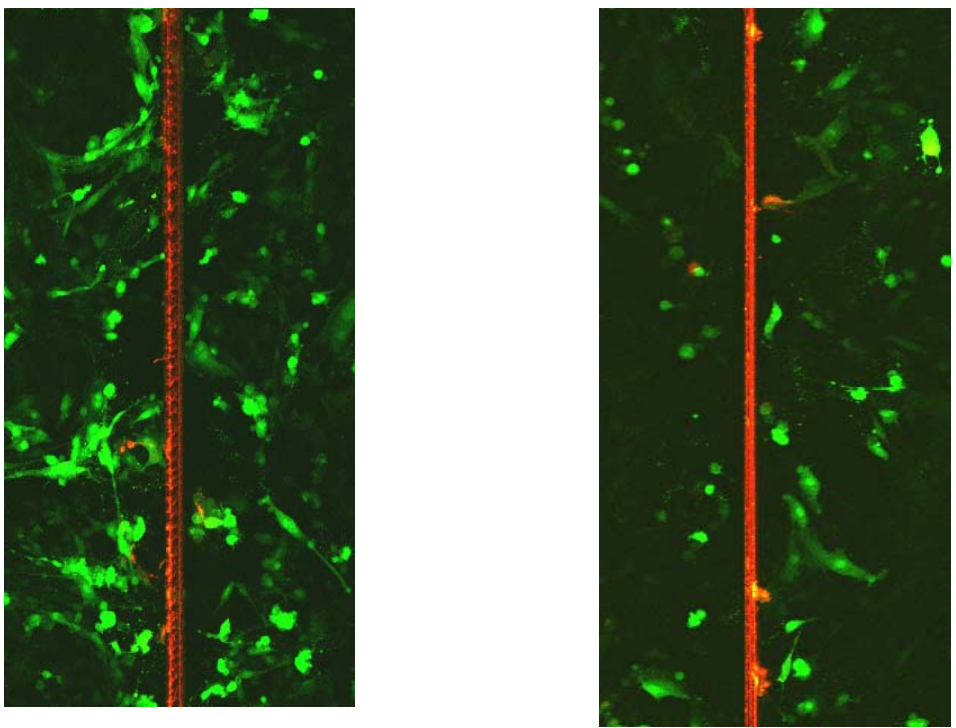

Cx43 ${ }^{+/+}$

$\mathrm{Cx} 43^{+/-}$

Figura 62 - Junção Comunicante do tipo Gap (GJIC) detectada pelo método de scrape-loading e transferência do corante em cultura de células de APTII aos 4 dias. Monocamada de células confluentes foram scraped com um bisturi e incubadas com amarelo de lúcifer $(0,5 \%)$ acrescido de albumina rodamina $(0,25 \%)$ em PBS por 5 minutos à temperatura ambiente ao abrigo da luz. As imagens foram feitas em microscópio de fluorescência. Em A e B pode-se observar as culturas de APTII de camundongos machos $\mathrm{C}_{4} 43^{+/+}$e $\mathrm{C} \times 43^{+/-}$, respectivamente. Em C e D podem-se observar as culturas de APTII de camundongos fêmeas $\mathrm{C} \times 43^{+/+}$e $\mathrm{C} \times 43^{+/-}$, respectivamente. Os experimentos foram realizados em triplicata 


\subsubsection{Avaliação da capacidade de proliferação dos pneumócitos do tipo II em cultura primária}

Os resultados que dizem respeito ao estudo da proliferação celular dos pneumócitos em cultura primária são apresentados na tabela 32.

Tabela 32 - Capacidade de proliferação dos APTII em cultura primária em diferentes dias de incubação

\begin{tabular}{|c|c|c|c|}
\hline \multirow[t]{2}{*}{ Grupos } & \multicolumn{3}{|c|}{ Dias de cultura (D.O.) } \\
\hline & 4 & 6 & 8 \\
\hline $\mathrm{C} \times 43^{+/+}$ & $0,660 \pm 0,043^{A}$ & $1,113 \pm 0,042^{C}$ & $0,964 \pm 0,011^{\mathrm{C}}$ \\
\hline $2 \mathrm{C}_{\mathbf{1 3}}+\mathrm{t}-$ & $0,901 \pm 0,010^{B}$ & $1,588 \pm 0,015^{\mathrm{A}}$ & $1,096 \pm 0,018^{A}$ \\
\hline & $0,595 \pm 0,026^{A}$ & $0,975 \pm 0,023^{\mathrm{D}}$ & $0,899 \pm 0,013^{\mathrm{D}}$ \\
\hline Cx43 & $0,821 \pm 0,034^{B}$ & $1,462 \pm 0,042^{B}$ & $1,023 \pm 0,007^{\mathrm{B}}$ \\
\hline
\end{tabular}

Em todo o decorrer do experimento, os camundongos $\mathrm{C} \times 43^{+/+}$ apresentaram as menores taxas de proliferação pelo teste de MTT. A partir do sexto dia de incubação, quando comparado os camundongos $\mathrm{C} \times 43^{+/-}$e os $\mathrm{C} \times 43^{+/+}$, os camundongos machos apresentaram as maiores taxas de proliferação. Os resultados mantiveram a mesma tendência no oitavo dia de cultura. Com a quantidade de células utilizadas, de $6 \times 10^{6}$ células por $\mathrm{ml}$, no sexto dia a cultura já era $100 \%$ confluente. Assim, a morte das células, por apoptose, pôde ser observada com menor densidade óptica (D.O.) da suspensão no oitavo dia de cultura. 


\section{CONCLUSÕES}

a. A deleção de um dos alelos da Cx43 não determina maior incidência de neoplasmas pulmonares espontâneos em camundongos.

b. A deleção de apenas um alelo da Cx43 culmina com a maior susceptibilidade dos camundongos machos a uretana, e estes apresentam predominantemente lesões histologicamente classificadas como mais agressivas.

c. Adenomas pulmonares de camundongos que apresentam deleção em um dos alelos da conexina 43 apresentam maior índice de proliferação, avaliado por meio de células positivas para o PCNA.

d. A Cx43 tem a expressão mais abundante em tecido pulmonar livre de lesões de camundongos em comparação com as demais, seguida das Cx26, 46, e 32 respectivamente.

e. Há um decréscimo da expressão das Cxs26, 32 e 46 após o tratamento com uretana.

f. Nossos estudos in vitro revelaram que os APTII dos camundongos Cx43 ${ }^{+/-}$são GJIC deficientes e proliferam mais rapidamente.

De acordo com o conjunto de nossos resultados, pode-se concluir a Cx43 é importante para o desenvolvimento de neoplasmas pulmonares induzidos quimicamente pela uretana. 


\section{REFERÊNCIAS}

ABRAHAM, V.; CHOU, M. L.; DEBOL, T. K. M.; KOVAL, M. Phenotypic control of gap junctional communication by cultured alveolar epithelial cells. Am. J.

Physiol., v. 276, p. L825-834,1999.

ABRAHAM, V.; CHOU, M. L.; GEORGE, P.; POOLER, P.; ZAMAN, A.;

SAVANI, R. C.; KOVAL, M. Heterocellular gap junctional communication between alveolar epithelial cells. Am. J. Physiol. Lung Cell Mol. Physiol., v. 280, p. L1085-L1093, 2001.

ACKERT, C. L.; GITTENS, J. E.; O'BRIEN, M. J.; EPPIG, J. J.; KIDDER, G. M. Intercellular communication via connexin43 gap junctions is required for ovarian folliculogenesis in the mouse. Dev. Biol., v. 33, p. 258-270, 2001.

ALBERTS, B.; BRAY, D.; LEWIS, J.; RAFF, M.; ROBERTS, K.; WATSON, J. D. Molecular biology of the cell. Publishe. by Garland. Publishing, New York, NY: United States of America, 1994. p.

ALVES, L. A.; COUTINHO-SILVA, R.; PERSECHINI, P. M.; SPRAY, D. C.; SAVINO, W.; CAMPOS DE CARVALHO, A. C. Are there functional gap junctions or junctional hemichannels in macrophages? Blood., v. 88, p. 328334, 1996.

ANZINI, P.; NEUBERG, D. H. H.; SCHACHNER, M.; NELLES, E.; WILLECKE, K.; ZIELASEK, J.; TOYKA, K. V.; SUTER, U.; MARTINI, R. Structural abnormalities and deficient maintenance of peripheral nerve myelin in mice lacking the gap junction protein connexin 32. J. Neurosci., v. 17, p. 4545-4551, 1997.

ARNESON, M. L.; CHENG, H. L.; LOUIS, C. F. Characterization of the ovinelens plasmamembrane protein-kinase substrates. Eur. J. Biochem., v. 234, p. 670-679, 1995.

BAI, S.; SCHOENFELD, A.; PIETRANGELO, A.; BURK, R. D. Basal promoter of the rat connexin-32 gene: identification and characterization of an essential element and its DNA-biding protein. Mol. Cell Biol., v. 15, p. 1439-1445, 1995.

BANOUB, R. W.; FERNSTROM, M.; MALKINSON, A. M.; RUCH, R. J. Enhancement of gap junctional intercellular communication by dibutyryl cyclic AMP in lung epithelial cells. Anticancer Res., v. 16, p. 3715-3719, 1996.

BATIAS, C.; DEFAMIE, N.; LABLACK, A.; THEPOT, D.; FENICHEL, P.; SEGRETAIN, D.; POINTIS, G. Modified expression of testicular gap-junction connexin 43 during normal spermatogenic cycle and in altered spermatogenesis. Cell Tissue Res., v. 298, p. 113-21, 1999. 
BECHBERGER, J. F.; KHOO, N. S.; NAUS, C. C. Analysis of connexin43 expression under the control of a metallothionein promoter. Cell Growth Differ., v. 7, p. 1403-1413, 1996.

BEER, D. G.; MALKINSON, A. M. Genetic influence on type II or Clara cell origin of pulmonary adenomas in urethane-treated mice. J. Natl. Cancer Inst., v. 75 , p. 963-969, 1985.

BENNETT, M. V. L.; BARRIO, L. C.; BARGIELLO, T. A.; SPRAY, D. C.; HERTZBERG, E.; SAEZ, J. C. Gap junctions: new tools, new answers, new questions. Neuron., v. 6, p. 305-320, 1991.

BERENMBLUM, I.; BEN-ISHAI, D.; HARAN-GHERA, N.; LAPIDOT, A.; SIMON, E.; TRAININ, N. Skin initiating action and lung carcinogenesis by derivatives of urethane (ethyl carbamate) and related compounds. Biochem. Pharmacol., v. 2, p. 168-176, 1959.

BERGOFFEN, J.; SCHERER, S. S.; WANG, S.; ORONZI-SCOTT, M.; BONE, L.; PAUL, D. L.; CHEN, K.; LENSCH, M. W.; CHANCE, P.; FISCHBECK, K. Connexin mutations in X-linked Charcot-Marie Tooth disease. Science, v. 262, p. 2039-2042, 1993.

BERTHOUD, V. M.; BEYER, E. C.; KURATA, W. E.; LAU, A. F.; LAMPE, P. D. The gap-junction protein connexin 56 is phosphorylated in the intracellular loop and carboxy-terminal region. Eur. J. Biochem., v. 244, p. 89-97, 1997.

BERTHOUD, V. M.; MONTEGNA, E. A.; ATAL, N.; AITHAL, N. H.; BRINK, P. R.; BEYER, E. C. Heteromeric connexons formed by lens connexins, connexin43 and connexin56. Eur. J. Cell. Biol., v. 80, p. 11-19, 2000.

BEVANS, C. G.; KORDEL, M.; RHEE, S. K.; HARRIS, A. L. Isoform composition of connexin channels determines selectivity among second messegers and uncharged molecules. J. Biol. Chem., v. 273, p. 2808-2816, 1998.

BEYER, E. C. Gap junctions. Int. Rev. Cytol., v. 137C, p. 1-37, 1993.

BEYER, E. C. Molecular cloning and developmental expression of two chick embryo gap junction proteins. J. Biol. Chem., v. 265, p. 14439-14443, 1990.

BEYER, E. C.; PAUL, D. L.; GOODENOUGH, D. A. Connexin43: a protein from rat heart homologous to a gap junction protein fromliver. J. Cell. Biol., v. 105, p. 2621-2629, 1987.

BOITANO, S. From the extracellular matrix to cell and tissue function in the alveolar epithelium. Am. J. Physiol. Lung Cell Mol. Physiol., v. 280, p. L189L190, 2001. 
BOND, S. L.; BECHBERGER, J. F.; KHOO, N. K.; NAUS, C. C. Transfection of C6 glioma cells with connexin32: the effects of expression of a nonendogenous gap junction protein. Cell Growth Differ., v. 5, p. 179-186,1994.

BOTTNER, H. Fatal aplastic anemia after urethane treatment of myeloid leukemia (abstract). J. Am. Med. Ass., v. 139, p. 1233-1234, 1949.

BRADSHAW, S. L.; NAUS, C. C.; ZHU, D.; KIDDER, G. M.; HAN, V. K. Insulinlike growth factor binding protein-4 gene expression is induced by transfection of gapa junction connexin43 gene in a C6 glima cell line. Growth Regul., v. 3, p. 26-29, 1993.

BRINK, P. R.; CRONIN, K.; BANACH, K.; PETERSON, E.; WESTPHALE, E. M.; SEUL, K. H.; RAMANAN, S. V.; BEYER, E. C. Evidence for heteromeric gap junction channels formed from rat connexin43 and human connexin37. Amer. J. Physiol. Cell Physiol., v. 42, p. C1386-C1396, 1997.

BRISSETTE, J. L.; KUMAR, N. M.; GILULA, N. B.; HALL, J. E.; DOTTO, G. P. Switch in gap junction protein expression is associated with selective changes in junctional permeability during keratinocyte differentiation. Proc. Natl. Acad. Sci. USA., v. 91, p. 6453-6457, 1994.

BRUZZONE, R.; HAEFLIGER, J. A.; GIMLICH, R. L.; PAUL, D. L. Connexin40, a component of gap junctions in vascular endothelium, is restricted in its ability to interact with other connexins. Mol. Biol. Cell., v. 4, p. 7-20, 1993.

BRUZZONE, R.; WHITE, T. W.; PAUL, D. L. Connections with connexins: the molecular basis of direct intercellular signaling. Eur. J. Biochem., v. 238, p. 1$27,1996$.

BRUZZONE, R.; WHITE, T. W.; YOSHIZAKI, G.; PATINO, R.; PAUL, D. L. Intercellular channels in teleosts: functional characterization of two connexins from Atlantic croaker. FEBS Lett., v. 358, p. 301-304, 1995.

BURT, J. M.; SPARY, D. C. Inotropic agents modulate gap junctional conductance between cardiac myocytes. Am. J. Physiol., v. 254, p. H12061210, 1988.

CANCELAS, J. A.; KOEVOET, W. L.; DE KONING, A. E.; MAYEN, A. E.; ROMBOUTS, E. J.; PLOEMACHER, R. E. Connexin-43 gap junctions are involved in multiconnexin-expressing stromal support of hemopoietic progenitors and stem cells. Blood., v. 96, n. 2, p. 498-505, 2000.

CASCIO, M.; GOGOL, E.; WALLACE, B. A. The secundary structure of gap junctions. Influence of isolation methods and proteolysis. J. Biol. Chem., v. 265, p. 2358-2364, 1990. 
CESEN-CUMMINGS, K.; FERNSTROM, M. J.; MALKINSON, A. M.; RUCH, R. $J$. Frequent reduction of gap junctional intercellular communication and connexin 43 expression in human and mouse lung carcinoma cells.

Carcinogenesis, v. 19, n. 1, p. 61-67, 1998.

CHANSON, M.; FANJUL, M.; BOSCO, D.; NELLES, E.; SUTER, S.;

WILLECKE, K.; MEDA, P. Enhanced secretion of amylase from exocrine pancreas of connexin32-deficient mice. J. Cell. Biol., v. 141, p. 1267-1275, 1998.

CHARLES, A. C.; NAUS, C. C.; ZHU, D.; KIDDER, G. M.; DIRKSEN, E. R.; SANDERSON, M. J. Intercellular calcium signaling via gap junctions in glioma cells. J. Cell Biol., v. 118, p. 195-201, 1992.

CHEN, S. C.; PELLETIER, D. B.; AO, P.; BOYNTON, A. L. Connexin43 reverses the phenotype of transformed cells and alters their expression of cyclin/cyclin-dependent kinases. Cell Growth Differ., v. 6, p. 681-690, 1995b.

CHEN, Z. Q.; LEFEBVRE, D.; BAI, X. H.; REAUME, A.; ROSSANT, J.; LYE, S. $J$. Identification of two regulatory elements within the promoter region of the mouse connexin43 gene. J. Biol. Chem., v. 270, p. 3863-3868, 1995 a.

CLIVE, D. R.; GREENE, J. J. Cooperation of protein disulfide isomerase and redox environment in the regulation of NF-kappaB and AP1 binding to DNA. Cell Biochem. Funct., v. 14, p. 49-55, 1996.

COLE, W. C.; GARFIELD, R. E. Evidence for physiological regulation of myometrial gap junction permeability. Am. J. Physiol., v. 251, p. C411-420, 1986.

CONDORELLI, D. F.; PARENTI, R.; SPINELLA, F.; SALINARO, A. T.; BELLUARDO, N.; CARDILE, V.; CICIRATA, F. Cloning of a new gap junction gene (Cx36) highly expressed in mammalian brain neurons. Eur. J. Neurosci., v. 10 , p. $1202-1208,1998$.

CORTI, M.; BRODY, A. R.; HARRISON, J. H. Isolation and primary culture of murine alveolar type II cells. Am. J. Resp. Cell Mol. Biol., v. 14, p. 309-315, 1996.

COWEN, P. N. Strain differences in mice to carcinogenic action of urethane and its non-carcinogenicity in chicks and guinea-pigs. Brit. J. Cancer, v. 4, p. 245253, 1950.

CRONIER, L.; DEFAMIE, N.; DUPAYS, L.; THEVENIAU-RUISSY, M.; GOFFIN, F.; POINTS, G.; MALASSINE, A. Connexin expression and gap junctional intercellular communication in human first trimester trophoblast. Mol. Hum.

Reproduc., v. 8, p. 1005-1013, 2002. 
CROW, D. S.; BEYER, E. C.; PAUL, D. L.; KOBE, S. S.; LAU, A. F. Phosphorylation of connexin43 gap junction protein in uninfected and Rous sarcoma virus-transformed mammalian fibroblasts. Mol. Cell. Biol., v. 10, p. 1754-1763, 1990.

CURY, P. M.; LICHTENFELS, A. J. F. C.; REYMÃO, M. S. F.; CONCEIÇÃO, G. M. S.; CAPELOZZI, V. L.; SALDIVA, P. H. N. Urban levels of air pollution modifies the proression of urethane-induced lung tumours in mice. Pathol. Res. Pract., v. 196, p. 627-633, 2000.

DAGLI, M. L. Z.; WARD, J. M.; MERLINO, G.; ENOMOTO, A.; MARONPOT, R. Liver pathology in genetically engineered mice. In: WARD, J. M.; MAHLER, J. F.; MARONPOT, R. R.; SUNDBERG. J. P. (Ed.) Pathology of genetically engineered mice. Ames, UK: lowa State University Press, EUA, 2000. p. 211.

DAGLI, M. L.; YAMASAKI, H.; KRUTOVSKIKH, V.; OMORI, Y. Delayed liver regeneration and increased susceptibility to chemical hepatocarcinogenesis in transgenic mice expressing a dominant-negative mutant of connexin32 only in the liver. Carcinogenesis, v. 25, p. 483-492, 2004.

DAHL, G.; MILLER, T.; PAUL, D.; VOELLMY, R.; WERNER, R. Expression of functional cell-cell channels from cloned rat liver gap junction complementary DNA. Science., v. 236, p. 1290-1293, 1987.

DAHL, G.; WERNER, R.; LEVINE, E.; RABADAN-DIEHL, C. Mutation analysis of gap junction formation. Biophys. J., v. 62, p. 172-180, 1992.

DARROW, B. J.; LAING, J. G.; LAMPE, P. D.; SAFFITZ, J. E.; BEYER, E. C. Expression of multiple connexins in cultured neonatal rat ventricular myocytes. Circ. Res., v. 76, p. 381-387, 1995.

DAS SARMA, J.; MEYE, R. A.; WANG, F.; ABRAHAM, V.; LO, C. W.; KOVAL, M. Multimeric connexin interactions prior to the trans-Golgi network. J. Cell Sci., v. 114, Pt 22, p. 4013-24, 2001.

DAVIES, T. C.; BARR, K. J.; JONES, D. H.; ZHU, D.; KIDDER, G. M. Múltiple members of the connexin gene family participe in preimplantation development of the mouse. Dev. Genet., v. 18, p. 234-243, 1996.

DERMIETZEL, R.; GAO, Y.; SCEMES, E.; VIEIRA, D.; URBAN, M.; KREMER, M.; BENNETT, M. V.; SPRAY, D. C. Connexin43 null mice reveal that astrocytes express multiple connexins. Brain Res. Brain Res. Rev., v. 32, n. 1 , p. $45-56,2000$.

DERMIETZEL, R.; WANG, T. K.; SPRAY, D. S. The gap junction family: structure, function and chemistry. Anat. Embryol., v. 182, p. 517-528, 1990. 
DEVEREUX, T. R.; HOOK, G. E. R.; FOUTS, J. R. Foreign compound metabolism by isoleted cell from rat lung. Drug Dispos., v. 7, p. 70-75, 1979.

DEVRIES, S. H.; SCHWARTZ, E. A. Modulation of an electral synapse between solitary pairs of catfish horizontal cells by dopamine and second messengers. J. Physiol. (Lond)., v. 414, p. 351-375, 1989.

DIEZ, J. A.; AHMAD, S.; EVANS, W. H. Assembly of heteromeic connexons in guinea-pig liver en route to the Golgi apparatus, plasma membrane and gap junctions. Eur. J. Biochem., v. 262, p. 142-148, 1999.

DIEZ, J. A.; ELVIRA, M.; VILLALOBO, A. Phosphorylation of connexin-32 by the epidermal growth factor receptor tyrosine kinase. Ann. N. Y. Acad. Sci., V. 766, p. 477-480, 1995.

DIXON, D.; HORTON, J.; HASEMAN, J. K.; TALLEY, F.; GREENWE

LL, A.; NETTESHEIM, P.; HOOK, G. E.; MARONPOT, R. R. Histomorphology and ultrastructure of spontaneous pulmonary neoplasms in strain A mice. Exp. Lung Res., v. 17, p. 131-155, 1991.

DOBBS, L. G.; GONZALEZ, R. F. Isolation and Culture of pulmoary alveolar epithelial type II cells. In: DOBBS, L. G. Culture of epithelial cells $\left(2^{\text {nd }}\right.$ ed.), New York: Wiley-Liss, Inc., 2002, p. 277-301.

DUBINA, M. V.; IATCKII, N. A.; POPOV, D. E.; VASIL'EV, S. V.;

KRUTOVSKIKH, V. A. Connexin 43, but not connexin 32, is mutated at advanced stages of human sporadic colon cancer. Oncogene., v. 21, p. 49924996, 2002.

DUFLOTDANCER, A.; PICCOLI, C.; RPLLAND, A.; YAMASAKI, H.; MESNIL, $M$. Long-term connexin-meiated bystander effect in highly tumorigeneic human cells in vivo in herpes simplex virus thymidine kinase ganciclovir gene therapy. Gene Therapy., v. 5, p. 1372-1378, 1998.

DUGA, S.; ASSELTA, R.; DELGIACCO, L.; MALCOVATI, M.; RONCHI, S.; TENCHINI, M. L.; SIMONIC, T. A new exon in the 5' untranslated region of the connexin32 gene. Eur. J. Biochem., v. 259, p. 188-196, 1999.

DUPONT, E.; EL AOUMARI, A.; BRIAND, J. P.; FROMAGET, C.; GROS, D. Cross-linking of cardiac gap junction connexons by thiol/disulfide exchange. J. Membr. Biol., v. 108, p. 247-252, 1989.

EBIHARA, L.; BEYER, E. C.; SWENSON, K. I.; PAUL, D. L.; GOODNENOUGH, $D$. A. Cloning and expression of a xenopus embryonic gap junction protein.

Science., v. 241, p. 1194-1195, 1989. 
ECHETEBU, C. O.; ALI, M.; IZBAN, M. G.; MAEKAY, L.; GARFIELD, R. E. Localization of regulatory protein binding sites in the proximal region of human myometrial connexin 43 gene. Mol. Huma. Reprod., v. 5, p. 757-766, 1999.

EGHBALI, B.; KESSLER, J. A.; REID, L. M.; ROY, C.; SPRAY, D. C. Involvment of gap junctions in tumorigenisis: transfection of tumor cells with connexin 32 cDNA retards growth in vivo. Proc. Natl. Acad. Sci. USA., v. 88, p. 10701-10705, 1991.

EGHBALI, B.; KESSLER, J. A.; SPRAY, D. C. Expression of gap junction channels in communication-incompetent cells stable transfection with cDNA enconding connexin 32. Proc. Natl. Acad. Sci. USA., v. 87, p. 1328-1331, 1990.

ELFGANG, C.; ECKERT, R.; LICHTENBERG-FRATE, H.; BUTTERWECK, A.; TRAUB, O.; KLEIN, R. A.; HULSER, D. F.; WILLECKE, K. Specific permeability and selective formation of gap junction channels in connexin-transfected HeLa cells. J. Cell. Biol., v. 129, p. 805-817, 1995.

EL-FOULY, M. H.; TROSKO, J. E.; CHANG, C. C. Scrape-loading and dye transfer: a rapid and simple technique to study gap junctional intercellular communication. Exp. Cell Res., v. 168, p. 422-430, 1987.

EL-SABBAN, M. E.; PAULI, B. U. Adhesion-mediated gap junctional communication between lung-metastatatic cancer cells and endothelium. Inv. Met., v. 14, p. 164-76, 1994-95.

ERICKSON, L. A.; JIN, L.; WOLLAN, P. C.; THOMPSON, G. B.; VAN HEERDEN, J.; LLOYD, R. V. Expression of p27kip1 and Ki-67 in benign and malignant thyroid tumors. Mod. Pathol., v. 11, p. 169-174, 1998.

FALK, M. M. Connexin-specific distribution withim gap junctions revealed inliving cells. J. Cell. Sci., v. 113, p. 4109-4120, 2000.

FALK, M. M.; BUEHLER, L. K.; KUMAR, N. M.; GILULA, N. B. Cell-free synthesis and assembly of connexins into functional gap junction membrane channels. EMBO J., v. 16, p. 2703-2716, 1997.

FALK, M. M.; GILULA, N. B. Connexin membrane protein biosysnthesis is influenced by polypeptide positioning within the translocon and signal peptidase access. J. Biol. Chem., v. 273, p. 7856-7864, 1998.

FIELD, K. J.; LANG, C. M. Hazards of urethane (ethyl carbamate): a review of the literature. Lab. Anim., v. 22, p. 255-262, 1988. 
FILHO, V. W.; MONCAU, J. E. Mortalidade por câncer no Brasil 1980-1995: padrões regionais e tedências temporais. Ver. Assoc. Med. Bras., v. 48, n. 3, p. $250-257,2002$.

FISHMAN, G. I.; SPRAY, D. C.; LEINWAND, L. A. Mlecular characterization and functional expression of the human cardiac gap junction channel. J. Cell. Biol., v. 11, p. 589-598, 1990.

FITZGERALD, D. J.; MESNIL, M.; OYAMADA, M.; TSUDA, H.; ITO, N.; YAMASAKI, $\mathrm{H}$. Changes in gap junction protein (connexin 32 ) gene expression during rat liver carcinogenesis. J. Cell Biochem., v. 41, p. 97-102, 1989.

FLEISHMAN, S. J.; UNGER, V. M.; YEAGER, M.; BEN-TAL, N. A C ${ }^{\alpha}$ model for the transmembrane ( hélices of gap junction intercellular channels. Molec. Cell, v. 15, p. 879-888, 2004.

FOOTE, C. I.; ZHOU, L.; ZHU, X.; NICHOLSON, B. J. the pattern of dissulfide linkages in the extracellular loop regions of connexin 32 suggests a model for the docking interface of gap junctions. J. Cell Biol., v. 140, p. 1187-1197, 1998.

FUJIMOTO, K.; NAGAFUCHI, A.; TSUKITA, S.; KURAOKA, A.; OHOKUMA, A.; SHIBATA, Y. Dynamics of connexins, E-cadherin and alpha-catenin on cell membranes during gap junction formation. J. Cell Sci., v. 110, p. 311-322, 1997.

FUSHIKI, S.; PEREZ VELAZQUEZ, J. L.; ZHANG, L.; BECHBERGER, J. F.; CARLEN, P. L.; NAUS, C. C. Changes in neuronal migration in neocortex of connexin43 null mutant mice. J. Neuropathol. Exp. Neurol., v. 62, n. 3, p. 304-314, 2003.

GABRIEL, H. D.; JUNG, D.; BUTZLER, C.; TEMME, A.; TRAUB, O.; WINTERHAGER, E.; WILLECKE, K. Transplacental uptake of glucose is decreased in embryonic lethal connexin26-deficient mice. J. Cell Biol., v.140, p. 1453-1461, 1998

GAO, Y.; SPRAY, D. C. structural changes in lenses of mice lacking the gap junction protein connexin43. Invest. Ophthalmol. Vis. Sci., v. 39, p. 1198-1209, 1998.

GEIMONEN, E.; JIANG, W.; ALI, M.; FISHMAN, G. I.; GARFIELD, R. E.; ANDERSEN, J. Activation of protein kinase $\mathrm{C}$ in human uterine smooth muscle induces connexin-43 gene transcription through an AP-1 site in the promoter seuqence. J. Biol. Chem., v. 271, p. 23667-23674, 1996.

GEORGE, C. H.; KENDALL, J. M.; EVANS, W. H. Intracellular trafficking pathways in the assenbly of connexins into gap junctions. J. Biol. Chem., v. 274, p. 8678-8685, 1999. 
GHOSHROY, S.; GOODENOUGH, D. A.; SOSINSKY, G. E. Preparation, characterization, and structure of half gap junction layers split with urea and EGTA. J. Membr. Biol., v. 146, p. 15-28, 1995.

GIEPMANS, B. N. G.; MOOLENAR, W. H. The gap junction protein connexin43 interacts with the second PDZ domain of the zona occludens-1 protein. Curr. Biol., v. 8, p. 931-934, 1998.

GIMLICH, R. L.; KUMAR, N. M.; GILULA, N. B. Differential regulation of the levels of threee gap junctional communication by fluorescent dye transfer.

Biotechniques, v. 18, p. 490-497, 1995.

GITTENS, J. E.; MHAWI, A. A.; LIDINGTON, D.; OUELLETTE, Y.; KIDDER, G. $M$. Functional analysis of gap junctions in ovarian granulosa cells: distinct role for connexin43 in early stages of folliculogenesis. Am. J. Physiol. Cell

Physiol., v. 284, n. 4, p. C880-7, 2003.

GOLDBERG, G. S.; BECHBERGER, J. F.; NAUS, C. C. A pre-loading method of evaluating gap junctional communication by fluorescent dye transfer.

Biotechniques, v. 18, p. 490-497, 1995.

GOLDBERG, G. S.; BECHBERGER, J. F.; TAJMA, Y.; MERRITT, M.; OMORI, Y.; GAWINOWICZ, M. A.; NARAYANAN, R. T. A. N. Y.; SANAI, Y.; YAMASAKI, H.; NAUS, C. C.; TSUDA, H.; NICHOLSON, B. J. Connexin43 suppresses MFG-E8 while inducing contact growth inhibition of glioma cells. Cancer Res., v. 60, p. $6018-6026,2000$.

GOLDBERG, G. S.; LAMPE, P. D.; NICHOLSON, B. J. Selective transfer of endogenous metabolites through gap junctions composed of different connexins. Nat. Cell Biol., v. 1, p. 457-459, 1999.

GOLDBERG, G. S.; LAMPE, P. D.; SHEEDY, D.; STEWART, C. C.; NICHOLSON, B. J.; NAUS, C. C. G. Direct isolation and analysis of endogenous transjunctional ADP from Gja1 transfected C"glioma cells. Exp. Cell. Res., v. 239, p. 82-92, 1998.

GOLDBERG, G. S.; MORENO, A. P.; LAMPE, P. D. Gap junctions between cells expressing connexin 43 or 32 show inverse permselectivity to adenosine and ATP. J. Biol. Chem., v. 277, p. 36725-36730, 2002.

GONG, X. H.; AGOPIAN, K.; KUMAR, N. M.; GILULA, N. B. Genetic factors influence cataract formation in alpha 3 connexin knockout mice. Dev. Genet., v. 24, p. 27-32, 1999.

GONG, X. H.; BALDO, G. J.; KUMAR, N. M.; GILULA, N. B.; MATHIAS, R. T. Gap junctional coupling in lenses lacking alpha(3) connexin. Proc. Nat. Acad.

Sci. USA, v. 95, p. 15303-15308, 1998. 
GOODENOUGH, D. A.; DICK, J. S.; LYONS, J. E. Lens metabolic cooperation: a study of mouse lens transport and permeability visualized wit freezesubstitution autodiography and electronmicroscopy. J. Cell Biol., v. 86, p. 576589, 1980.

GOODENOUGH, D. A.; GILULA, N. B. The splitting of hepatocyte gap junctions and zonula accudentes with hypertonic disaccharides. J. Cell Biol., v. 61, p. 575-590, 1974.

GOODENOUGH, D. A.; STOECKNIUS, W. The isolation of mouse hepatocytes gap junctions. Preliminary chemical characterization and X-ray diffraction. J. Cell Biol., v. 54, p. 646-656, 1972.

GRAEBER, S. H. M.; HULSER, D. F. Connexin transfection induces invasive properties in HeLa cells. Exp. Cell Res., v. 243, p. 142-149, 1998.

GRASSI, F.; MONACO, L.; FRATAMICO, G.; DOLCI, S.; IANNINI, E.; CONTI, M.; EUSEBI, F.; STEFANINI, M. Putative second messengers affect cell coupling in the seminiferous tubules. Cell Biol. Int. Rep., v. 10, p. 631-639, 1986.

GREEN, C. R. Evidence mounts for the role of gap junctions during development. Bioessays., v. 8, p. 7-10, 1988.

GRIFA, A.; WAGNER, C. A.; D'AMBROSIO, L.; MELCHIONDA, S.; BERNARDI, F.; LOPEZ-BIGAS, N.; RABIONET, R.; ARBONES, M.; MONICA, M. D.; ESTIVILL, X.; ZELANTE, L.; LANG, F.; GASPARINI, P. Mutations in GJB6 cause nonsyndromic autosomal dominant deafness at DFNA3 locus. Nat. Genet., v. 23, p. 16-18, 1999.

GRIFFIN, M.; BHANDARI, R.; HAMILTON, G.; CHAN, Y. C.; POWELL, J. T. Alveolar type II cell-fibroblast interactions, synthesis and secretion of surfactant and type I collagen. J. Cell Sci., v. 105, p. 423-432, 1993.

GUERRERO, P. A.; SCHUESSLER, R. B.; DAVIS, L. M.; BEYER, E. C.; JOHSON, C. M.; YAMADA, K. A.; SAFFITZ, J. E. Slow ventricular conduction in mice heterozygous for a connexin 43 null mutation. J. Clin. Invest., v. 99, n. 8, p. 1991-1998, 1997.

GUERRIER, A.; FONLUPT, P.; MORAND, I.; RABILLOUD, R.; AUDEBET, C.; KRUTOVSKIKH, V.; GROS, D.; ROUSSET, B.; MUNARI-SILEN, Y. Gap junctions and cell polarity: connexin32 and connexin43 expressed in polarized thyroid epithelial cells assemble into separate gap junctions, which are lcated in disinct regions of the lateral plasma membrane domain. J. Cell Sci., v. 108, p. 2609-2617, 1995. 
GUO, Y.; ALFORD, A. I.; MARTINEZ-WILLANS, C.; RANNELS, D. E. Extracellular matrix modulates expression of connexin messenger RNA and protein by alveolar epithelial cells. Chest., v. 120, p. 17S-19S, 2001.

GUPTA, R.; DANI, H. M. In vitro formation of organ-specific ultimate carcinogens of 4-dimethylaminoazobenzene and urethan by microsomes.

Toxicol. Lett., v. 45, p. 49-53, 1989.

GUPTA, V. K.; BERTHOUD, V. M.; ATAL., N.; JARILLO, J. A.; BARRIO, L. C.; BEYER, E. C. Bovine connexin44, a lens gap junction protein: molecular cloning, immunologic characterization, and functional expression. Invest.

Ophthalmol. Vis. Sci., v. 35, p. 3747-3758, 1994.

HADDOW, A.; SEXTON, W. A. Influence of carbamic esters (urethanes) on experimental animal tumors. Nature, v. 157, p. 500-503, 1946.

HAGENDORFF, A.; SCHUMACHER, B.; KIRCHHOFF, S.; LUDERITZ, B.; WILLECKE, K. Conduction disturbances and increased atrial vulnerability in connexin40-deficient mice analyzed by transesophageal stimulation.

Circulation, v. 99, p. 1508-1515, 1999.

HAMMOND, C.; HELENIUS, A. Quality control in the secretory pathway. Curr. Opin. Cell Biol., v. 7, p. 523-529, 1995.

HASEGAWA, S.; YAMADA, K.; INOUE, H.; AZUMA, N.; SUZUKI, M.; MATSUOKA, T. Establishment of pulmonary alveolar type II cell line from p53deficient mice. Lung, v. 179, p. 21-29, 2001.

HAUBRICH, S.; SCHWARTZ, H. J.; BUKAUSKAS, F.; LICHTENBERG-FRATE, H.; TRAUB, O.; WEINGART, R.; WILLECKE, K. Incompatibility of connexin 40 and connexin 43 hemichannels in gap junctions between mammalian cells is determinated by intracellular domains. Mol. Biol. Cell., v. 7, p. 1995-2006, 1996.

HE, D. S.; JIANG, J. X.; TAFFET, S. M.; BURT, J. M. Formation of heteromeric gap junction channels by connexins 40 and 43 in vascular smooth muscle cells. Proc. Nat. Acad. Sci. USA., v. 96, p. 6495-6500, 1999.

HELLMANN, P.; GRUMMER, R.; SCHIRRMAECHER, K.; ROOK, M.; TRAUB, O.; WINTERHAGER, E. Transfection with different connexin genes alters growth and differentiation of human choriocarcinoma cells. Exp. Cell Res., v. 246, p. 480-490, 1999.

HENNEMANN, H.; DAHL, E.; WHITE, J. B.; SCHWARZ, H. J.; LALLEY, P. A.; CHANG, S.; NICHOLSON, B. J.; WILLECKE, K. Two gap junction genes, connexin 31.1 and 30.3 , are closly linked on mouse chromosome 4 and 
preferentially expressed in skin. J. Biol. Chem., v. 267, p. 17225-17233, 1992a.

HENNEMANN, H.; KOZJEK, G.; NICHOLSON, B. J.; WILLECKE, K. Molecular cloning of mouse connexin 26 and 32: similar genomic organization but distinct promotor seuqences of two gap junction genes. Eur. J. Cell Biol., v. 58, p. 81$89,1992 b$.

HENNEMANN, H.; SUCHYNA, T.; LICHTENBERG-FRATÉ, H.; JUNGBLUTH, S.; DAHL, E.; SCHWARZ, J.; NICHOLSON, B. J.; WILLECKE, K. Molecular cloning and functional expression of mouse connexin40, a second gap junction gene preferentially expressed in lung. J. Cell Biol., v. 117, p.1299-1310, 1992c.

HERBERLEIN, W.; WODOPIA, R.; BÄRTSCH, P.; MAIRBÄURL, H. Possible role of ROS as mediators of hyperoxia-induced ion transport inhibition of alveolar ephitelial cells. Am. J. Physiol., v. 278, p. L640-L648, 2000.

HERTZBERG, E. L.; SKIBBENS, R. V. A protein homologous to the 27,000 dalton liver gap junction protein is present in a wide variety of species and tissue. Cell., v. 39, p. 61-69, 1984.

HEYNKES, R.; KOZJEK, G.; TRAUB, O.; WILLECKE, K. Identification of arat liver cDNA and mRNA coding for the $28 \mathrm{kDa}$ gap junction protein. FEBS Lett., v. 205, p. 56-60, 1986.

HIRSCHBACK, J. S.; LINDERT, M. C.; CHASE, J.; CALVERY, T. Effects of urethane in treatment of leukemia and metastatic malignant tumors. JAMA, v. 136, p. 90-95, 1948.

HIRSCHI, K. K.; XU, C. E.; TSUKAMOTO, T.; SAGER, R. Gap junction genes Cx26 and Cx43 individually suppress the cancer phenotype of human mammary carcinoma cells and restore differentiation potential. Cell Growth. Differ., v. 7, p. 861-870, 1996.

HOFFLER, U.; EL-MASRI, H. A.; GHANAYEM, B. I. Cytochrome P450 2E1 (CYP2E1) is the principal enzyme responsible for urethane metabolism: comparative studies using CYP2E1-Null and wildtype mice. J. Pharm. Exp. Therap., v. 305, p. 557-564, 2003.

$\mathrm{HOH}$, J. H.; LAL, R.; JOHN, S. A.; REVEL, J. P.; ARNSDORF, M. F. Atomic force microscopy and dissection of gap junctions. Science, v. 253, p. 14051408, 1991.

HOOEVR, J. E. Remington`s Pharmaceutical sciences, 14th ed. Local: NY, Mac Publishing Co. 1970. 
HORIO, Y.; SCHRUMP, D. S.; CHEN, A.; RICE, P.; MALKINSON, A. M.; $\mathrm{ROTH}$, J. A. K-ras and p53 mutations are early and late events, respectively, in urethane induced pulmonary carcinogenesis. Molec. Carcinog., v. 17, p. 217223, 1996.

HOUGHTON, F. D.; THONNISSEN, E.; KIDDER, G. M.; NAUS, C. C.; WILLECKE, K.; WINTERHAGER, E. Doubly mutant mice, deficient in connexin32 and -43 , show normal prenatal development of organs were the two gap junction proteins are expressed in the same cells. Dev. Genet., v. 24, p. 5-12, 1999.

HUANG, R. P.; FAN, Y.; HOSSAIN, M. Z.; PENG, A.; ZENG, Z. L.; BOYTON, A. $\mathrm{L}$. Reversion of the neoplastic phenotype of human glioblastoma cells by connexin 43 (Gja1). Cancer Res., v. 58, p. 5089-5096, 1998.

HUGHES, E. W.; MARTIN-BODY, R.; SARELIEUS, I. H.; SINCLAIR, J. D. Effects of urethane-chloralose anaesthesia on respiration in the rat. Clin. Exp. Pharmacol. Physiol., v. 9, p. 119-127, 1982.

ISAKSON, B. E.; EVANS, W. H.; BOITANO, S. Intercellular Ca+2 signaling in alveolar epithelial cells through gap junctions and by extracellular ATP. Am. J. Physiol. Lung Cell Mol. Physiol., v. 280, p. L221-L228, 2001.

ITAHANA, K.; TANAKA, T.; MORIKAZU, Y.; KOMATU, S.; ISHIDA, N.; TAKEYA, T. Isolation and characterization of a novel connexin gene, Cx-60, in porcine ovarian follicles. Endocrinology, v. 139, p. 320-329, 1998.

ITO, A.; KATOH, F.; KATAOKA, T. R.; OKADA, M.; TSUBOTA, N.; ASADA, H.; YOSHIKAWA, K.; MAEDA, S.; KITAMURA, Y.; YAMASAKI, H.; NOJIMA, H. A role for heterologous gap junctions between melanoma and endothelial cells in metastasis. J. Clin. Invest., v. 105, n. 9, p. 1189-97, 2000.

JAFFE, W. G. Carcinogenic action of ethyl urethane on rats. Cancer Res., v. 7, p. 107-127, 1947.

JIANG, J. X.; GOODENOUGH, D. A. Heteromeric connexons in lens gap junction channels. Proc. Natl. Acad. Sci. USA, v. 93, p. 1287-1291, 1996.

JIANG, J. X.; PAUL, D. L.; GOODENOUGH, D. A. Posttranslational phosphorylation of lens fiber Cx46: a slow occurrence. Invest. Ophthalmol. Vis. Sci., v. 34, p. 3558-3565, 1993.

JIANG, J. X.; WHITE, T. W.; GOODENOUGH, D. A.; PAUL, D. L. Molecular cloning and functional characterization of chick lens fiber connexin 45.6 Mol. Biol. Cell., v. 5, p. 363-373, 1994. 
JINN, Y.; ICHIOKA, M.; MARUMO, F. Expression of connexin32 and connexin43 gap junction proteins and $\mathrm{E}$-cadherin in human lung cancer. Cancer Lett., v. 127, p. 161-169, 1998.

JOHNSON, C. M.; GREEN, K. G.; KANTER, E. M.; BOU-ABBOUD, E.; SAFFITZ, J. E.; YAMADA, K. A.Voltage-gated Na+ channel activity and connexin expression in Cx43-deficient cardiac myocytes. J Cardiovasc. Electrophysiol., v. 10, n. 10, p. 1390-1401, 1999.

JOHNSON, R. G.; MEYER, R. A.; LI, X. R.; PREUS, D. M.; TAN, L.; GRUNENWALD, H.; PAULSON, A. F.; LAIRD, D. W.; SHERIDAN, J. D. Gap junctions assemble in the presence of cytoskeletal inhibitors, but enhanced assembly requires microtubules. Exp. Cell Res., v.275, n. 1, p. 67-80, 2002.

JONES, K. J.; HOLLAND, J. F.; FOUREMAN, G. L.; FOUTS, J. R. Xenobiotic metabolism in Clara cells and alveolar type II cells isolated from lungs of rats treated with beta-naphthoflavone. J. Pharmacol. Exp. Ther., v. 225, p. 316319, 1983.

JONGEN, W. N.; FITSGERALD, D. J.; ASAMOTO, M.; PICCOLI, C.; SLAGA, T. J.; GROS, D.; TAKEICHI, M.; YAMASAKI, H. Regulation of connexin 43mediated gap junctional intercellular communiation by $\mathrm{Ca}+2$ in mouse epidermal cells is controlled by E-cadherin. J. Cell Biol., v. 114, p. 545-555, 1991.

JORDAN, K.; CHODOCK, R.; HAND, A. R.; LAIRD, D. W. The origin of annular junctions: a mechanism of gap junction internalization. J. Cell Sci., v. 114, p. 763-773, 2001.

JOU, Y. S.; LAYHE, B.; MATESIC, D. F.; CHANGE, C. C.; DE FEIJTER, A. W.; TROSKO, J. E. Inhibition of gap junctional intercellular communication and malgnant transformation of rat liver epithelial cells by neu oncogene.

Carcinogenesis, v. 16, p. 311-317, 1995.

JOU, Y. S.; MATESTIC, D.; DUPONT, E.; LU, S. C.; RUPP, H. L.; MADHUKAR, B. V.; OH, S. Y.; TROSKO, J. E.; CHANG, C. C. Restoration of gap-junctional intercellular communication in a communication-deficient rat liver cell mutant by transfection with connexin 43 cDNA. Mol. Carcinog., v. 8, p. 234-244, 1993.

JUNEJA, S. C.; BARR, K. J.; ENDERS, G. C.; KIDDER, G. M. Defects in the germ line and gonads of mice lacking connexin43. Biol. Reprod., v. 60, p. 1263-1270, 1999.

KAMIBAYASHI, Y.; OYAMADA, Y.; MORI, M.; OYAMADA, M. Aberrant expression of gap junction proteins (connexins) is associated with tumor progression during ultistage mouse skin carcinogenesis in vivo.

Carcinogenesis., v. 16, n. 6, p. 1287-1297, 1995. 
KANEMITSU, M. Y.; JIANG, W.; ECKHART, W. Cdc2-mediated phosphorylation of the gap junction protein, connexin43, during mitosis. Cell Growth. Differ., v. 9, p. 13-21, 1998.

KANNO, Y.; LOEWENSTEIN, W. R. Cell-to-cell passage of large molecules. Nature, v. 212, p. 629-630, 1966.

KANTER, H. L.; SAFFITZ, J.; BEYER, E. C. Cardiac myocytes express multiple gap junction proteins. Circ. Res., v. 70, p. 438-444, 1992a.

KANTER, H. L.; SAFFITZ, J.; BEYER, E. C. Molecular cloning and characterization of expression of two novel human cardiac gap junction proteins. Circulation, v. 86, p. 492, 1992b.

KASPER, M.; TRAUB, O.; RELMANN, H.; GROSSMANN, H.; MULLER, M.; WENZEL, K. W. Upregulation of gap junction protein connexin 43 in alveolar epithelial cells of rats with radiation-induced pulmonary fibrosis. Histochem. Cell Biol., v. 106, p. 419-424, 1996.

KELSELL, D. P.; DUNLOP, J.; HODGINS, M. B. Human diseases: clues to cracking the connexin code? Trends Cell Biol., v. 11, 2-6, 2001.

KELSELL, D. P.; DUNLOP, J.; STEVENS, H. P.; LENCH, N. J.; LIANG, J. N.; PARRY, G.; MUELLER, R. F.; LEIGH, I. M. Connexin 26 mutations in hereditary non-syndromic sensorineural deafness. Nature, v.387, p.80-83, 1997.

KIANG, D. T.; FUKUSHIMA, L. H.; HIEBER, A. D.; SHIMABUKURO, K. A.; SAKR, W. A.; BERTRAM, J. S. Reduced levels of connexin43 in cervical dysplasia: inducible expression in a cervical carcinoma cell line decreases neoplastic potential with implications for tumor progression. Carcinogenesis, v. 21, p. 1097-1109, 2000.

KIANG, D. T.; JIN, N.; TU, Z. J.; LIN, H. H. Upstream genomic sequence of the human connexine26 gene. Gene, v. 199, p. 165-171, 1997.

KIMURA, T.; OGITA, K.; KUSUI, C.; OHASHI, K.; AZUMA, C.; MURATA, Y. What knockout mice can tell us about parturition. Rev. Reprod., v. 4, n. 2, p.7380, 1999.

KING, T. J.; LAMPE, P. D. Mice deficient for the gap junction protein Connexin32 exhibit increased radiation-induced tumorigenesis associated with elevated mitogen-activated protein kinase (p44/Erk1, p42/Erk2) activation.

Carcinogenesis, v. 25, p. 669-680, 2004a.

KING, T. J.; LAMPE, P. D. The gap junction protein connexin32 is a mouse lung tumor suppressor. Cancer Res., v. 64, n. 20, p. 7191-6, 2004. 
KIRCHHOFF, S.; NELLES, E.; HAGENDORFF, A.; KRUGER, O.; TRAUB, O.; WILLECKE, K. Reduced cardiac conduction velocity and predisposition to arrhythmias in connexin40-deficient mice. Curr. Biol., v. 26, p. 299-302, 1998.

KOFFLER, L.; ROSHONG, S.; KYU PARK, I.; CESEN-CUMMINGS, K.; THOMPSON, D. C.; DWYER-NIELD, L. D.; RICE, P.; MAMAY, C.; MALKINSON, A. M.; RUCH, R. J. Growth inhibition in G(1) and altered expression of cyclin D1 and p27(kip-1) after forced connexin expression in lung and liver carcinoma cells. J. Cell Biochem., v. 79, p. 347-354, 2000.

KOJIMA, T.; SAWADA, N.; CHIBA, H.; KOKAI, Y.; YAMAMOTO, M.; URBAN, M.; LEE, G. H.; HERTZBERG, E. L.; MOCHIZUKI, Y.; SPRAY, D. C. Induction of tight junctions in human connexin 32 (hCx32)-transfected mouse hepatocytes: connexin 32 interacts with occluding. Biochem. Biophys. Res. Commun., v. 266, p. 222-229, 1999.

KOVAL, M. Sharing signals: connecting lung epithelial cells with gap junction channels. Am. J. Physiol. Lung Cell Mol. Physiol., v. 283, p. L875-L893, 2002.

KOVAL, M.; HARLEY, J. E.; HICK, E.; STEINBERG, T. H. Connexin46 is retained as monomers in a trans-Golgi compartment of osteoblastic cells. J. Cell Biol., v. 137, n. 4, p. 847-857, 1997.

KOYAMA, S.; STAO, E.; NOMURA, H.; KUBO, K. Bradykinin stimulates type II alveolar cells to release neutrophil and monocyte chemotatic activity and inflammatory cytokines Am. J. Pathol., v. 153, n. 6, p. 1883-1893, 1998.

KRUGER, O.; PLUM, A.; KIM, J. S.; WINTERHAGER, E.; MAXEINER, S.; HALLAS, G.; KIRCHHOFF, S.; TRAUB, O.; LAMERS, W. H.; WILLECKE, K. Defective vascular development in connexin 45-deficient mice. Development. v. 127, p.4179-4193, 2000.

KRUTOVSKIKH, V. A.; MAZZOLENI, G.; MIRONOV, N.; OMORI, Y.; AGUELON, A. M.; MESNIL, M.; BERGER, F.; PARTENSKY, C.; YAMASAKI, H. Altered homologous and heterologous gap-junctional intercellular communication in primary human liver tumors associated with aberrant protein localization but not gene mutation of connexin 32. Int. J. Cancer., v. 56, p. 8794, 1994.

KRUTOVSKIKH, V. A.; MIRONOV, N.; YAMASAKI, H. Human connexin 37 is polymorphic but not mutated in tumors. Carcinogenesis, v. 17, p. 1761-1763, 1996.

KRUTOVSKIKH, V. A.; OYAMADA, M.; YAMASAKI, H. Seuqential changes of gap-junctional intercellular communications during multistage rat liver carcinogenesis: direct measurement of communication in vivo.

Carcinogenesis, v. 12, p. 1701-1706, 1991. 
KRUTOVSKIKH, V. A.; PICCOLI, C.; YAMASAKI, H.; YAMASAKI, H. Gap junction intercellular communication propagates cell death in cancerous cells. Oncogene., v. 21, n. 13, p. 1989-1999, 2002.

KRUTOVSKIKH, V. A.; YAMASAKI, H. Connexin gene mutations in human genetic deseases. Mutat. Res., v. 462, p. 197-207, 2000.

KRUTOVSKIKH, V. A.; YAMASAKI, H.; TSUDA, H.; ASAMOTO, M. Inhibition of intrinsic gap junction intercellular communication and enhancement of tumorigenicity of the rat bladder carcinoma cell line BC31 by a dominantnegative connexin 43 mutant. Mol. Carcinogen., v. 23, p. 254-261, 1998.

KUMAR, M.; NISHII, K.; NAKAMURA, K.; TAKEDA, N.; SUZUKI, M.; SHIBATA, $Y$. Loss of connexin45 causes a cushion defect in early cardiogenesis.

Development., v. 127, p. 3501-3512, 2000.

KUMAR, N. M.; FRIEND, D. S.; GILULA, N. B. Synthesis and assembly of human beta 1 gap junctions in BHK cells by DNA transfection with the human beta 1 cDNA. J. Cell. Sci., v. 108, p. 3725-3734, 1995.

KUMAR, N. M.; GILULA, N. B. Molecular biology and genetics of gap junction channels. Semin. Cell. Biol., v. 3, p. 3-16, 1992.

KUMAR, N. M.; GILULA, N. B. The gap junction communication channel. Cell, v. 84, p. $381-386,1996$

LAING, J. G.; BEYER, E. C. The gap junction protein connexin43 is degraded via the ubiquitin proteasome pathway. J. Biol. Chem., v. 270, p. 26399-26403, 1995.

LAING, J. G.; TADROS, P. N.; WESTPHALE, E. M.; BEYER, E. C. Degradation of connexin43 gap junctions involves both the proteasome and the lysosome.

Exp. Cell Res., v. 263, p. 482-492, 1997.

LAING, J. G.; WESTPHALE, E. M.; ENGELMANN, G. L.; BEYER, E. C. Characterization of the gap junction protein, connexin45. J. Membr. Biol., v. 139, p. 31-40, 1994.

LAIRD, D. W.; CASTILLO, M.; KASPRZAK, L. Gap junction turnover, intracellular trafficking, and phosphorylation of connexin43 in brefeldin A-treated rat mammary tumor cells. J. Cell Biol., v. 131, p. 1193-1203, 1995.

LAIRD, D. W.; PURANAM, K. L.; REVEL, J. P. Turnover and phosphorylation dynamics of connexin43 gap junction protein in cultured cardiac myoytes.

Biochem. J., v. 273, p. 67-72, 1991. 
LANG, L. M.; BEYER, E. C.; SCHWARTZ, A. L.; GITLIN, J. D. Molecular cloning of a rat uterine gap junction protein and analysis of gene expression during gestation. Am. J. Physiol., v. 260, p. E787-E793, 1991.

LARSEN, W. J.; TUNG, H. N.; MURRAY, S. A.; SWENSON, C. A. Evidence for the participation of actin microfilaments and bristle coats in the internalization of gap junction membrane. J. Cell Biol., v. 83, p. 576-587, 1979.

LASH, J. A.; CRITSER, E. S.; PRESSLER, M. L. Cloning of a gap junctional protein from vascular smooth muscle and expression in two-cell mouse embryos. J. Biol. Chem., v. 265, p. 13113-13117, 1990.

LAU, A. F.; KURATA, W. E.; KANEMITSU, M. Y.; LOO, L. W.; WARNCRAMER, B. J.; ECKHART, W.; LAMPE, P. D. Regulation of connexin43 function by activated tyrosine protein kinases. J. Bioenerg. Biomenbr., v. 28, p. 359-368, 1996.

LECANDA, F.; WARLOW, P. M.; SHEIKH, S.; FURLAN, F.; STEINBERG, T. H.; CIVITELLI, R. Connexin43 deficiency causes delayed ossification, craniofacial abnormalities, and osteoblast dysfunction. J. Cell Biol., v. 151, n. 4, p. 931-944, 2000.

LEE, S. W.; TOMASETTO, C.; PAUL, D.; KEYOMARSI, K.; SAGER, R. Transcriptional downregulation of gap-junction proteins blocks junctional communication in human mammary tumor cell lines. J. Cell Biol., v. 118, p. 1213-1221, 1992.

LEE, S. W.; TOMASETTO, C.; SAGER, R. Positive selection of candidate tumor-suppressor genes by subtractive hybridization. Proc. Natl. Acad. Sci. USA., v. 88, p. 2825-2829, 1991.

LEE, S.; GILULA, N. B.; WARNER, A. E. Gap junctional communication and compaction during preimplantation stages of mouse development. Cell., v. 51, p. 851-860, 1987.

LEE, Y. C.; YELLOWLEY, C. E.; LI, Z.; DONAHUE, H. J.; RANNELS, D. E. Expression of functional gap junctions in cultured pulmonary alveolar epithelial cells. Am. J. Physiol., v. 272, n. 6, Pt1, p. L1105-L1114, 1997.

LERNER, D. L.; YAMADA, K. A.; SCHUESSLER, R. B.; SAFFITZ, J. E. Accelerated onset and increased incidence of ventricular arrhythmias induced by ischemia in Gja1-deficient mice. Circulation., v. 8, p. 547-552, 2000.

LETTERER, E. Anatomicropathologic observation of cadavers of patients treated with urethane (abstract). J. Am. Med. Ass., v. 139, p. 125-126, 1949. 
LI, H.; LIU, T. F.; LAZARAK, A.; PERACCHIA, C.; GOLDBERG, G. S.; LAMPE, P. D.; JOHNSON, R. G. Properties and regulation of gap junctional hemichannels in the plasma membranes of cultured cells. J. Cell Biol., v. 134, p. 1019-1030, 1996.

LIAO, Y.; DAY, K. H.; DAMON, D. N.; DULING, B. R. Endothelial cell-specific knockout of connexin 43 causes hypotension and bradycardia in mice. Proc.

Natl. Acad. Sci. USA., v. 98, n. 17, p. 9989-9994, 2001.

LIN, H.; ZHANG, Z.; HAN, Y.; NAUS, C. C.; YU, K. R.; HOLTZER, H. Functional expression of gap junction gene Gja1 and the myogenic differentiation of rhabdomyosarcoma cells. Sci. China B., v. 38, p. 305-312, 1995.

LIU, F.; GUTSTEIN, D. E. The cardiac gap junction: a potential therapeutic target in the treatment of heart disease. Mt. Sinai J. Med., v. 69, n. 6, p. 421424, 2002.

LIU, S.; TAFFET, S.; STONER, L.; DELMAR, M.; VALLANO, M. L.; JALIFE, J. A structural basis for the unequal sensitivity of the major cardiac and liver gap junctions to intracellular acidification: the carboxyl tail length. Biophys. J., v. 64, p. 1422-1433, 1993.

LIU, X. Z.; XIA, X. J.; XU, L. R.; PANDYA, A.; LIANG, C. Y.; BLANTON, S. H.; BROWN, S. D.; STEEL, K. P.; NANCE, W. E. Mutations in connexin31 underlie recessive as well as dominant non-syndromic hearing loss. Hum. Mol. Genet., v. 9, p. 63-67, 2000.

LIVAK, K. J.; SCHMITTGEN, T. D. Analysis of relative gene expression data using real-time quantitative PCR and the 2(-Delta Delta C(T)) Method.

Methods, v. 25, p. 402-408, 2001.

LO, C. W. The role of gap junction membrane channels in development. J. Bioenerg Biomembr., v. 28, p. 379-385, 1996.

LO, C. W.; COHEN, M. F.; HUANG, G. Y.; LAZATIN, B. O.; PATEL, N.; SULLIVAN, R.; PAUKEN, C.; PARK, S. M. J. Gja1 gap junction gene expression and gap junctional communication in mouse neural crest cells. Dev. Genet., v. 20, p. 119-132, 1997.

LOEWENSTEIN, W. R.; KANO, Y. Intercellular communication and the control of tissue growth: lack of communication between cancer cells. Nature, v. 209, p. 1248-1249, 1966.

LOWRY, O. H.; ROSEBROUGH, N. J.; FARR, A. L.; RANDALL, R. J. Protein measurement with the folin phenol reagent. J. Biol. Chem., v. 193, p. 264-275, 1951. 
MACARI, F.; LANDAU, M.; COUSIN, P.; MEVORAH, B.; BRENNER, S.; PANIZZON, R.; SCHORDERET, D. F.; HOHL, D.; HUBER, M. Mutation in the gene for connexin 30.3 in a family with erythrokeratodermia variabilis. Am. J. Hum. Genet., v. 67, p. 1296-1301, 2000.

MACKAY, D.; IONIDES, A.; KIBAR, Z.; ROULEAU, G.; BERRY, V.; MOORE, A.; SHIELS, A.; BHATTACHARYA, S. Connexin 46 mutations in autosomal dominant congenital cataract. Am. J. hum. Genet., v. 64, p. 1357-1364, 1999.

MAESTRINI, E.; KORGE, B. P.; OCANA-SIERRA, J.; CALZOLARI, E.; CAMBIAGHI, S.; SCUDDER, P. M.; HOVNANIAN, A.; MONACO, A. P.; MUNRO, C. S. A missense mutation in connexin26, D66H, causes mutilating keratoderma with sensorineural deafness (vohwinkel's syndrome) in three unrelated families. Hum. Mol. Genet., v. 8, p. 237-1243, 1999.

MAKOWSKI, L.; CASPAR, D. L. D.; PHILLIPS, W. C.; GOODENOUGH, D. A. Gap junction structures. II, analysis of the X-ray diffraction data. J. Cell Biol., v. 74, p. 629-645, 1977.

MALKINSON, A. M. Genetic studies on lung tumor susceptibility and histogenesis in mice. Environ. Health Perspect., v. 93, p. 149-159, 1992.

MANJUNATH, C. K.; GOINGS, G. E.; PAGE, E. Cytoplasmic surface and intramembrane components of rat heart gap junctional proteins. Am. J.

Physiol., v. 246, p. H865-875, 1984.

MANSON, R. J.; KALINA, M.; NIELSEN, L. D.; MALKINSON, A. M.; SHANNON, J. M. Surfactant protein $C$ expression in urethane-induced murine pulmonary tumors. Am. J. Pathol., v. 156, p. 175-182, 2000.

MANTHEY, D.; BUKAUSKAS, F.; LEE, C. G.; KOSAK, C. A.; WILLECKE, K. Molecular cloning and functional expression of the mouse gap junction gene connexin-57 in human HeLa cells. J. Biol. Chem., v. 274, p. 14716-14723, 1999.

MARIANI, T. J.; DUNSMORE, S. E.; LI, Q.; YE, X.; PIERCE, R. A. Regulation of lung fibroblast tropoelastin expression by alveolar epithelial cells. Am. J.

Physiol., v. 274, p. L47-L57, 1998.

MASON, R. J.; KALINA, M.; NIELSEN, L. D.; MALKINSON, A. M.; SHANNON, J. M. Surfactant protein $C$ expression in urethane-induced murine pulmonary tumors. Am. J. Pathol., v. 156, p. 175-182, 2000.

MASON, R. J.; SHANNON, J. M. Alveolar type II cells. In: CRYSTAL, R. G.; WEST, J. B. (Ed.). The lung: Scientific Foundations. New York, Raven, 1997, p. 543-555. 
MASON, R. J.; WALKER, S. R.; SHIELDS, R. A.; HENSON, J. E.; WILLIANS, M. C. Identification of rat alveolar type II epithelial cells with a tannic acid and polychrome stain. Am. Rev. Respir., v. 131, p. 786-788, 1985.

MEHTA, P. P.; HOTZ-WAGENBLATT, A.; ROSE, B.; SHALLOWAY, D.; LOEWENSTEIN, W. R. Incorporation of the gene for a cell-cell channel protein into transformed cells leads to normalization of growth. J. Membr. Boil., v. 124, p. 207-225, 1991.

MEHTA, P. P.; YAMAMOTO, M.; ROSE, B. Transcription of the gene for the gap junctional protein connexin 43 and expression of functional cell-to-cell channels are regulated by cAMP. Mol. Biol. Cell., v. 3, p. 839-850, 1992.

MEHTA, P.; PEREZSTABLE, C.; NADJI, M.; MIAN, M.; ASOTRA, K.; ROOS, B. A. Suppression of human prostate cancer cell growth by forced expression of connexin genes. Develop. Genetics., v. 24, p. 91-110, 1999.

MESNIL, M.; KRUTOVSKIKH, V.; PICCOLI, C.; ELFGANG, C.; TRAUB, O.; WILLECKE, K.; YAMASAKI, $\mathrm{H}$. Negative growth control of HeLa cells by connexin genes : connexin species specificity. Cancer Res., v. 55, p.629-639, 1995.

MESNIL, M.; PICCOLI, C.; TIRABY, G.; WILLECKE, K.; YAMASAKI, H. Bystander killing of cancer cells by herpes simplex virus thymidine kinase gene is mediated by connexins. Proc. Natl. Acad. Sci. USA., v. 93, p. 1831-1835, 1996.

MESNIL, M.; PICCOLI, C.; YAMASAKI, H. A tumor suppressor gene, Gjb2, also mediates the bystander effect in HeLa cells. Cancer Res., v. 57, p. 2929-2932, 1997.

MEYER, R. A.; LAIRD, D. W.; REVEL, J. P.; JOHNSON, R. G. Inhibition of gap junction and adhrens junction assembly by connexin and A-CAM antibodies. J. Cell. Biol., v. 119, p. 179-189, 1992.

MICHALOPOULOS, G.; PITOT, H. C. Primary culture of parenchymal liver cells on collagen membranes. Exp. Cell Res., v. 94, p. 70-78, 1975.

MILKS, L. C.; KUMAR, N. M.; HOUGHTEN, R.; UNWIN, N.; GILULA, N. B. Topology of the 32-kd liver gap junction protein determined by site- directed antibody localizations. Embo J., v. 7, p. 2967-2975, 1988.

MILLER, J. A.; MILLER, E. C. The metabolic activation and nucleic acid adducts of naturally-occurring carcinogens: Recent results with ethyl carbamate and the spice flavors safrole and estragole. Br. J. Cancer, v. 48, p. 1-15, 1983. 
MILLER, T.; DAHL, G.; WERNER, R. Structure of a gap junction gene: rat connexin32. Bioscience Rep., v. 8, p. 455-464, 1988.

MIRVISH, S. S. The carcinogenic action and metabolism of urethan and Nhydroxyurethane. Adv. Cancer Res., v. 11, p. 1-42, 1968.

MITCHELL, J. A.; LYE, S. J. Regulation of connexin43 expression by c-fos and C-jun in myometrial cells. Cell Commun. Adhes., v. 8, p. 299-302, 2001.

MITCHELL, J. A.; OU, C.; CHEN, Z.; NISHIMURA, T.; LYE, S. J. Parathyroid hormone-induced up-regulation of connexin-43 messenger ribonucleic acid (mRNA) is mediated by sequences within both the promoter and the 3'untranslated region of the mRNA. Endocrinology, v. 142, p. 907-915, 2001.

MITSUMORI, K.; KOIZUMI, H.; NOMURA, T.; YAMAMOTO, S. Pathological features of spontaneous and induced tumors in transgenic mice carrying a human prototype c-Ha-ras gene used for six-month carcinogenicity studies. Toxicol. Pathol., n. 26, n. 4, p. 520-531, 1998.

MITSUMORI, K.; WAKANA, S.; YAMAMOTO, S.; KODAMA, Y.; YASUHARA, K.; NOMURA, T.; HAYASHI, Y.; MARONPOT, R. R. Susceptibility of transgenic mice carrying human prototype c-Ha-ras gene in a short-term carcinogenicity study of vinyl carbamate and ras gene analyses of the induced tumors. Mol. Carcinog., v. 20, n. 3, p. 298-307, 1997.

MONAGHAN, P.; PERUSINGHE, N.; CARLILE, G.; EVANS, W. H. rapid modulation of gap junction expression in mouse mammary gland during pregnancy, lactation, and involution. J. Histochem. Cytochem., v. 42, p. 931938, 1994.

MONTECINO-RODRIGUEZ, E.; DORSHKIND, K. Regulation of hematopoiesis by gap junction-mediated intercellular communication. J. Leukoc Biol., v. 70, n. 3, p. 341-347, 2001.

MONTECINO-RODRIGUEZ, E.; LEATHERS, H.; DORSHKIND, K. Expression of connexin 43 (Gja1) is critical for normal hematopoiesis. Blood, v. 96, p. 917924, 2000.

MORLEY, G. E.; TAFFET, S. M.; DELMAR, M. Intramolecular interactions mediate $\mathrm{pH}$ regulation of connexin43 channels. Biophys. J., v. 70, p. 12941302, 1996.

MORLEY, G. E.; VAIDYA, D.; JALIFE, J. Characterization of conduction in the ventricles of normal and heterozygous Cx43 knockout mice using optical mapping. J. Cardiovasc Electrophysiol., v. 11, n. 3, p. 375-377, 2000. 
MUNARI-SILEN, Y.; LEBRETHON, M. C.; MORAND, I.; ROUSSET, B.; SAEZ, J. M. Gap junction-mediated cell-to-cell communication in bovine and human adrenal cells. A process whereby cells increase their responsiveness to physiological corticotropin concentrations. J. Clin. Invest., v. 95, p. 1429-1439, 1995.

MUSIL, L. S.; BEYER, E. C.; GOODENOUGH, D. A. Expression of the gap junction protein connexin43 in embryonic chick lens: molecular clonig, ultrastructural localization, and post-translational phosphorylation. J. Membrane Biol., v. 116, p. 163-175, 1990.

MUSIL, L. S.; GOODNOUGH, D. A. Multisubunit assembly of an integral plasma membrane channel protein, gap junction connexin43, occurs after exit from the ER. Cell, v. 74, p. 1065-1077, 1993.

MUSIL, L. S.; LE, A. C.; VANSLYKE, J. K.; ROBERTS, L. M. Regulation of connexin degradtion as a mechanism to increase gap junction assembly and function. J. Biol. Chem., v. 275, p. 25207-25215, 2000.

NAUS, C. C.; BANI-YAGHOUB, M.; RUSHLOW, W.; BECHBERGER, J. F. Consequences of impaired gap junctional communication in glial cells. Adv. Exp. Med. Biol., v. 468, p. 373-381, 1999.

NAUS, C. C.; BOND, S. L.; BECHBERGER, J. F.; RUSHLOW, W. Identification of genes differentially expressed in $\mathrm{C} 6$ glioma cells trnafected with connexin43. Brain Res. Brain Res. Rev., v. 32, p. 259-266, 2000.

NAUS, C. C.; ELISEVICH, K.; ZHU, D.; BELLIVEAU, D. J.; DEL MAESTRO, R. F. Invivo growth of C6 glioma cells transfected with connexin43 cDNA. Cancer Res., v. 52, p. 4208-4213, 1992.

NAUS, C. C.; HEARN, S.; ZHU, D.; NICHOLSON, B. J.; SHIVERS, R. R. Ultrastructural analysis of gap junctions in $\mathrm{C} 6$ glioma cells transfected with connexin43 cDNA. Exp. Cell Res., v. 206, p. 72-84, 1993.

NEI, H.; SAITO, T.; YAMASAKI, H.; MIZUMOTO, H.; ITO, E.; KUDO, R. Nuclear localization of beta-catenin in normal and carcinogenic endometrium. Mol. Carcinogen., v. 25, p. 207-218, 1999.

NELLES, E.; BUTZLER, C.; JUNG, D.; TEMME, A.; GABRIEL, H. D.; DAHL, E.; TRAUB, O.; STUMPEL, F.; JUNGERMANN, K.; ZIELASEK, J.; TOYKA, K. V.; DERMETIEZEK, R.; WILLECKE, K. Defective propagation of signals generated by sympathetic nerve stimulation in the liver of connexin 32 deficient mice. Proc. Nat. Acad. Sci. USA, v. 93, p. 9565-9570, 1996. 
NEUHAUS, I. M.; BONE, L.; WANG, S.; IONASESCU, V.; WERNER, R. The human connexin32 gene is transcribed from two tissue-specific promoters. Bioscience Rep., v. 16, p. 239-248, 1996.

NEYTON, J.; TRAUTMANN, A. Single-channel currents of na intercelular junction. Nature, v. 317, p. 331-335, 1985.

NICHOLSON, B. J.; HUNKAPILLER, M. W.; GRIM, L. B.; HOOD, L. R.; REVEL, J. P. Rat liver gap junction protein: properties and partial sequence. Proc. Natl. Acad. Sci. USA., v. 78, p. 7594-7598, 1981.

NICHOLSON, B. J.; WEBER, P. A.; CAO, F.; CHANG, H.; LAMPE, P.; GOLDBERG, G. The molecular basis of selective permeability of connexins is complex and includes both size and charge. Braz. J. Med. Biol. Res., v. 33, p. 369-378, 2000.

NIESSEN, H.; HARZ, H.; BEDNER, P.; KRAMER, K.; WILLECKE, K. Selective permeability of different connexin channels to the second messenger inositol 1,4,5-trisphosphate. J. Cell Sci., v. 113, p. 1365-1372, 2000.

NIESSEN, H.; WILLECKE, K. Strongly decreased gap junctional permeability to inositol 1,4,5-trisphosphate in connexin32 deficient hepatocytes. FEBS Lett., v. 466 , p. $112-114,2000$.

NISHI, M.; KUMAR, N. M.; GILULA, N. B. Developmental regulation of gap junction gene during mouse embryonic development. Dev. Biol., v. 146, p. 117130, 1991.

NISHIMURA, M.; SAITO, T.; YAMASAKI, H.; KUDO, R. Suppression of gap junctional intercellular communication via 5' CpG island methylation in promoter region of E-cadherin gene in endometrial câncer cells. Carcinogenesis, v. 24, p. 1615-1623, 2003.

NOMORI, H.; MORINAGA, S.; KOBAYASHI, R.; TORIKATA, C. Protein 1 and clara cell 10-kDa protein distribution in normal and neoplastic tissues with emphasis on the respiratory system. Virchows Archiv., v. 424, p. 517-523, 1994.

O'BRIEN, A. D.; STANDIFORD, T. J.; CHRISTENSEN, P. J.; WILCOXEN, S. E.; PAINE, I. I. R. Chemotaxis of alveolar macrophages in response to signals derived from alveolar epithelial cells. J. Lab. Clin. Med., v. 131, n. 5, p. 417424, 1998a.

O'BRIEN, J.; AL-UBAIDI, M. R.; RIPPS, H. Connexin35: a gap junctional protein expressed preferentially in the skate retina. Mol. Cell Biol., v. 7, p. 233-243, 1996. 
O'BRIEN, J.; BRUZZONE, R.; WHITE, T. W.; ALUBAIDI, M. R.; RIPPS, H. Cloning and expression of two related connexins from the perch retina define a distinct subgroup of the connexin family. J. Neurosci., v. 18, p. 7625-7637, 1998b.

OGAWA, K.; IMAIDA, K.; MASUI, T.; KAWABE, M.; HASEGAWA, R.; KATO, K.; ITO, N.; SHIRAI, T. Chemically induced lung and forestomach neoplasias in transgenic mice carrymutant forms of the human c-Ha-ras transgene.

Carcinogenesis, v. 17, n. 2, p. 341-345,1996.

OLBINA, G.; ECKHART, W. Mutations in the second extracellular region of connexin 43 prevent localization to the plasma membrane, but do not affect its ability to suppress cell growth. Mol. Cancer Res., v. 1, p. 690-700, 2003.

OMORI, Y.; YAMASAKI, H. Gap junction proteins connexin32 and connexin43 partially acquire growth-suppressive function in HeLa cells by delection of their C-terminal tails. Carcinogenesis, v. 20, p. 1913-1918, 1999.

OU, C. W.; ORSINO, A.; LYE, S. J. Expression of connexin43 and connexin26 in the rat myometrium during pregnancy and labor is differentially regulated by mechanical and hormonal signals. Endocrinology, v. 138, p. 5398-5407, 1997.

OUGH, C. S. Ethylcarbamate in fermented beverages and foods. I. Naturally occurring ethylcarbamate. J. Agric. Food Chem. v. 24, p. 323, 1976.

PAINE, I. I. I. R.; ROLFE, M. W.; STANDIFORD, T. J.; BURDICK; M. D.; ROLLINS, B. J.; STRIETER, RM. MCP-1 expression by rat type II alveolar epithelial cells in primary culture. J. Immunol., v. 150, n. 10, p. 4561-4570, 1993.

PAN, T.; MASON, R. J.; WESTCOTT, J. Y.; SHANNON, J. M. Rat alveolar type II cells inhibit lung fibroblast proliferation in vivo. Am. J. Respir. Cell. Mol. Biol., v. 25, p. 353-361, 2001.

PARK, K. K.; LIEM, A.; STEWART, B. C.; MILLER, J. A. Vinyl-carbamate epoxide, a major strong electrophylic, mutagenic and carcinogenic metabolite of vinyl carbamate and ethyl carbamate (urethane). Carcinogenesis, v. 14, p. 441-450, 1993.

PATTERSON, E.; HADDON, A.; THOMAS, I. A.; WATAKINSON, J. M. Leukaemia treated with urethane compared to deep x-ray therapy. Lancet, v. 1, p. 677-683, 1946.

PAUL, D. L. Molecular cloning of cDNA from rat liver gap junction protein. J. Cell Biol., v. 103, p. 123-134, 1986. 
PAUL, D. L.; YU, K.; BRUZZONE, R.; GIMLICH, R. L.; GOODNOUGH, D. A. Expression of a dominant negative inhibitor of intercellular communication in the early Xenopus causes delamination and extrusion of cells. Development., v. 121, p. 371-381, 1995.

PEEBLES, K. A.; DUNCAN, M. W.; RUCH, R. J.; MALKINSON, A. M. Proteomic analysis of a neoplastic mouse lung epithelial cell line whose tumorigenicity has been abrogated by transfection with the gap junction structural gene for connexin 43, Gja1. Carcinogenesis, v. 24, p. 651-657, 2003.

PERACCHIA, C.; WANG, X. G.; PERACCHIA, L. L. Slow gating of gap junction channels and calmodulin. J. Membr. Biol., v. 178, p. 55-70, 2000.

PERKINS, G.; GOODNOUGH, D.; SOSINSKY, G. Formation of the gap junction intercellular channels requires a 30 degrees rotation for interdigitating two apposing connexons. J. Mol. Biol., v. 277, p. 171-177, 1998.

PERKINS, G.; GOODNOUGH, D.; SOSINSKY, G. three-dimensional structure of the gap junction connexon. Biophys. J., v. 72, p. 533-544, 1997.

PFEFFER, S. R.; ROTHMAN, J. E. biosynthetic protein transport and sorting by the endoplasmatic reticulum and Golgi. Annu. Rev. Biochem., v. 56, p. 829852, 1987.

PFEITER, I.; ANDERSON, C.; WERNER, R.; OLTRA, E. Redefining the structure of the mouse connexin43 gene: selective promoter usage and alternative splicing mechanisms yield transcripts with different translational efficiencies. Nucleic. Acids. Research., v. 32, p. 4550-4562, 2004.

PIECHOCKI, M. P.; TOTI, R. M.; FERNSTROM, M. J.; BURK, R. D.; RUCH, R. J. Liver cell-specific transcriptional regulation of connexin32. Biochim.

Biophys. Acta., v. 1491, p. 107-122, 2000.

PITTS, J. D.; SIMMS, J. W. Permeability of junctions between animal cells. Intercellular transfer of nucleotides but not of macromolecules. Exp. Cell. Res., v. 104, p. 153-163, 1977.

PLUM, A.; WINTERHAGER, E.; PESCH, J.; HALLAS, G.; ROSENTRETER, B.; TRAUB, O.; HERBERHOLD, C.; WILLECKE, K. Connexin31-deficiency in mice causes transient placental dysmorphogenesis but does not impair hearing and skin differentition. Dev. Biol., v. 231, p. 334-347, 2001.

POZZI, A.; RISEK, B.; KIANG, D. T.; GILULA, N. B.; KUMAR, N. M. Analysis of multiple gap junction gene products in the rodent and human mammary gland.

Exp. Cell. Res., v. 220, p. 212-219, 1995. 
PRINCEN, F.; ROBE, P.; GROS, D.; JARRY-GUICHARD, T.; GIELEN, J.; MERVEILLE, M. P.; BOURS, V. Rat gap junction connexin-30 inhibits proliferation of glioma cell lines. Carcinogenesis, v. 22, p. 507-513, 2001.

PROULX, A. A.; LIN, Z. X.; NAUS, C. C. G. Transfection of rhabdomyosarcoma cells with connexin43 induces myogenic differentiation. Cell Growth Differ., v. 8, p. 533-540, 1997 a.

QUINN, D.; TAGER, A.; JOSEPH, P. M.; BONOVENTRE, J. V.; FORCE, T.; HALES, C. A. Strech-induced mitogen-activated protein kinase activation an interleukin-8 production in type II alveolar cells. Chest, v. 116, n. 1, p. 89S-90S, 1999.

QUIST, A. P.; RHEE, S. K.; LIN, H.; LAL, R. Physiological role of gap-junctional hemichannels. Extracellular calcium-dependent isosmotic volume regulation. J. Cell. Biol., v. 148, p. 1063-1074, 2000.

RAE, R. S.; MEHTA, P. P.; CHANG, C. C.; TROSKO, J. E.; RUCH, R. J. Neoplastic phenotype of gap-junctional intercellular communication-deficient WB rat liver epithelial cells and its reversal by forced expression of connexin 32 . Mol. Carcinogen., v. 22, p. 120-127, 1998.

RAHMAN, S.; CARCLILE, G.; EVANS, W. H. Assembly of hepatic gap junctions. Topography and distribution of connexin 32 intracellular and plasma membranes determmined using sequence-specific antibodies. J. Biol. Chem., v. 268, p. 1260-1265, 1993.

RAHMAN, S.; EVANS, W. H. Topography of connexin32 in rat liver gap junctions. Evidence for an intramoleular disulfhide linkage connecting the two extracellular peptide loops. J. Cell. Sci., v. 100, p. 567-578, 1991.

REAUME, A. G.; DE SOUSA, P. A.; KULKARNI, S.; LANGILLE, B. L.; ZHU, D.; DAVIES, T. C.; JUNEJA, S. C.; KIDDER, G. M.; ROSSANT, J. Cardiac malformation in neonatal mice lacking connexin 43. Science, v. 267, p.18311834, 1995

REED, K. E.; WESTPHALE, E. M.; LARSON, D. M.; WANG, H. Z.; VEENSTRA, R. D.; BEYER, E. C. Molecular cloning and functional expression of human connexin37, an endothelial cell gap junction protein. J. Clin. Invest., v. 91, p. 997-1004, 1993.

REHM, S.; WARD, J. M.; SASS, B. Tumors of the lungs. IARC Sci. Publ., v. 111, p. 325-355, 1994.

REYMÃO, M. S. F.; CURY, P. M.; LICHTENFELS, A. J. F. C.; LEMOS, M.; BATTLEHNER, C. N.; CONCEIÇÃO, G. M. S.; CAPELOZZI, V. L.; MONTES, G. S.; JUNIOR, M. A .; BOHM, G. M.; SALDIVA, P. H.N. Urban air pollution 
enhances the formation of urethane-induced lung tumors in mice. Environ. Research, v. 74, p. 150-158, 1997.

RICE, W. R.; CONKRIGHT, J. J.; NA, C. L.; IKEGAMI, M.; SHANNON, J. M.; WEAVER, T. E. Maintenance of the mouse type II cell phenotype in vitro. Am. J. Physiol. Lung Cell Mol. Physiol., v. 283, p. L256-I264, 2002.

RICHARD, G.; SMITH, L. E.; BAILEY, R. A.; ITIN, P.; HOHL, D.; EPSTEIN, E. H.; DIGIOVANNA, J. J.; COMPTON, J. G.; BALE, S. J: Mutations in the human connexin gene GJB3 cause erythrokeratodermia variabilis. Natur. Gen., v.20, p.366-369, 1998

RISEK, B.; GUTHRIES, S.; KUMAR, N.; GILULA, N. B. Modulation of gap junction transcript and protein expression during pregnancy I the rat. J. Cell. Biol., v. 110, p. 269-282, 1990.

ROSCOE, W. A.; BARR, K. J.; MHAWI, A. A.; POMERANTZ, D. K.; KIDDER, G. M. Failure of spermatogenesis in mice lacking connexin43. Biol. Reprod., v. 65, n. 3, p. 829-838, 2001.

ROSE, B.; MEHTA, P. P.; LOEWENSTEIN, W. R. Gap-junction protein gene suppresses tumorigenicity. Carcinogenesis, v. 14, p. 1073-1075, 1993.

ROSENBERG, E.; FARIS, R. A.; SPRAY, D. C.; MONFILS, B.; ABREU, S.; DANISHEFSKY, I.; REID, L. M. Correlation of expression of connexin mRNA isoforms with degree of cellular differentiation. Cell Adhes. Commun., v. 4, p. 223-235, 1996.

RUCH, R. J.; CESEN-CUMMINGS, K.; MALKINSON, A. M. Role of gap junctions in lung neoplasia. Exp. Lung. Res., v. 24, p. 523-539, 1998.

RUCH, R. J.; PORTER, S.; KOFFLER, L. D.; DWYER-NIELD, L. D.; MALKINSON, A. M. Defective gap junctional intercellular communication in lung cancer: loss of an important mediator of tissue homeostasis and phenotypic regulation. Exp. Lung Res., v. 27, n. 3, p. 231-243, 2001.

RUP, D. M.; VEENSTRA, R. D.; WANG, H. Z.; BRINK, P. R.; BEYER, E. C. Chick connexin-56, a novel lens gap junction protein. Molecular cloning and functional expression. J. Biol. Chem., v. 268, p. 706-712, 1993.

SAEZ, J. C.; CONNOR, J. A.; SPRAY, D. C.; BENNETT, M. V. Hepatocyte gap junctions are permeable to the second messenger, iositol 1,4,5-trisphosphate, and to calcium ions. Proc. Natl. Acd. Sci. USA., v. 86, p. 2708-2712, 1989.

SAEZ, J. C.; NAIRN, A. C.; CZERNIK, A. J.; FISHMAN, G. I.; SPRAY, D. C.; HERTZBERG, E. L. Phosphorilation of connexin43 and the regulation of 
neonatal rat cardiac myocyte gap junctions. J. Mol. Cell. Cardiol., v. 29, p. 2131-2145, 1997.

SAEZ, J. C.; SPRAY, D. C.; NAIRN, A. C.; HERTZBERG, E.; GREENGARD, P.; BENNETT, M. V. cAMP increases junctional conductance and stimulates phosphorylation of the 27-kDa principal gap junction polypeptide. Proc. Natl. Acad. Sci. USA., v. 83, p. 2473-2477, 1986.

SAITO, T.; BARBIN, A.; OMORI, Y.; YAMASAKI, H. Connexin 37 mutations in rat hepatic angiosarcomas inuced by vinyl chloride. Cancer Res., v. 57, p. 375377, 1997.

SAITO, T.; SCHLEGEL, R.; ANDRESSON, T.; YUGE, L.; YAMAMOTO, M.; YAMASAKI, $\mathrm{H}$. Induction of cell transformation by mutated $16 \mathrm{~K}$ vacuolar $\mathrm{H}+-$ atpase (ductin) is accompanied by down-regulation of gap junctional intercellular communication and translocation of connexin 43 in NIH3t3 cells. Oncogene, v. 17, p. 1673-1680, 1998.

SALMON, A. G.; ZEISE, L. Risk of Carcinogenesis from Urethane Exposure. Boca Raton: CRC Press, 1991. p. 115.

SCHITTNY, J. C.; DJONOV, V.; FINE, A.; BURRI, P. H. Programmed cell death contributes to postnatal lung development. Am. J. Respir. Cell Mol. Biol., v. 18, p. 786-793, 1998.

SCHWARZMANN, G.; WIEGANDT, H.; ROSE, B.; ZIMMERMAN, A.; BENHAIM, D.; LOEWENSTEIN, W. R. diameter of the cell-to-cell junctional membrane channels as probed with neutral molecules. Science, v. 213, p. 551553, 1981.

SERVERS, N. J.; SHOVEL, K. S.; SLADE, A. M.; POWELL, T.; TWIST, V. W.; GREEN, C. R. Fate of gap junctions in isolated adult mammalian cardiomycytes. Circ. Res., v. 65, p. 22-42, 1989.

SHAPIRO, J. R.; KIRSCHBAUM, A. Intrinsic tissue response to induction of pulmonary tumors. Cancer Res., v. 11, p. 644-664, 1951.

SHIELS, A.; MACKAY, D.; IONIDES, A.; BERRY, V.; MOORE, A.; BHATTACHARYA, S. A missense mutation in the human connexin50 gene (GJA8) underlies autosomal dominant "zonular pulverulent" cataract, on chromosome 1q. Am. J. Hum. Gen., v. 62, p. 526-532, 1998.

SILVERSTEIN, D. M.; URBAN, M. G. A. O. Y.; MATTOO, T. K.; SPRAY, D. C.; ROZENTAL, R. Renal morphology in connexin43 knockout mice. Pediatr. Nephrol., v. 16, n. 6, p. 467-471, 2001. 
SIMON, A. M.; GOODENOUGH, D. A.; LI, E.; PAUL, D. L. Female infertility in mice lacking connexin 37. Nature, v. 6, p. 525-529, 1997.

SIMPSON, I.; ROSE, B.; LOEWENSTEIN, W. R. Size limit of molecules permeating the junctional membranes channels. Science, v. 195, p. 294-296, 1977.

SOHL, G.; DEGEN, J.; TEUBNER, B.; WILLECKE, K. A new alternatively spliced transcript of the mouse connexin32 gene is expressed in embrionic stem cells, oocytes, and liver. Exp. Cell Res., v. 266, p. 177-186, 2001.

SÖHL, G.; GILLEN, C.; BOSSE, F.; GLEICHMANN, M.; MÜLLER, H. W.; WILLECKE, K. A second alternative transcript of the gap junction gene connexin32 is expressed in murine Schawann cells and mondulated in injured sciatic nerve. Eur. J. Cell Biol., v. 69, p. 267-275, 1996.

SOHL, G.; WILLECKE, K. An update on connexin genes and their nomenclature in mouse and man. Cell Commun. Adhes., v. 10, p. 173-180, 2003.

SÖHL, G.; WILLECKE, K. Gap junctions and the connexin protein family. Cardiovas. Res., 2004, In press.

SPRAY, D. C.; BURT, J. M. Structure-activity relations of the cardiac gap junction channel. Am. J. Physiol., v. 28, p. C195-C205, 1990.

STEINBERG, T. H.; CIVITELLI, R.; GEIST, S. T.; ROBERTSON, A. J.; HICK, E.; VEENSTRA, R. D.; WANG, H. Z.; WARLOW, P. M.; WESTPHALE, E. M.; LAING, J. G. Connexin43 and connexin45 form gap junctions with different molecular permeabilities in osteoblastic cells. Embo J., v. 13, p. 744-750, 1994.

STONE, A. Connexin knockout provides a link to heart defects. Science, v. 267, n. 5205, p. 1773, 1995.

SULLIVAN, R.; RUANGVORAVAT, C.; JOO, D.; MORGAN, J.; WANG, B. L.; WANG, X. K.; LO, C. W. Structure sequence and expression of the mouse Gja1 gene encoding connexin 43. Gene, v. 130, p. 191-199, 1993.

TANNENBAUM, A.; VESSELINOVITCH, S. D.; MALTONI, C.; MITCHELL, D. S. Multipotential carcinogenicity of urethane in the sprague-dawley rat. Cancer Res., v. 22, p. 1362-1371, 1962.

TEMME, A.; BUCHMANN, A.; GABRIEL, H. D.; NELLES, E.; SCHWARZ, M.; WILLECKE, K. High incidence of spontaneous and chemically induced liver tumors inmice deficient for connexin32. Curr. Biol., v. 7, p. 713-716, 1997. 
THAETE, L. G.; GUNNING, W. T.; STONER, G. D.; MALKINSON, A. M. Cellular derivation of lung tumors in sensitive and resistant strains of mice: results at 28 and 56 weeks after urethane treatment. J. Natl. Cancer Inst., v. 78, p. 743-749, 1987.

THEIS, M.; DE WIT, C.; SCHLAEGER, T. M.; ECKARDT, D.; KRUGER, O.; DORING, B.; RISAU, W.; DEUTSCH, U.; POHL, U.; WILLECKE, K. Endothelium-specific replacement of the connexin43 coding region by a lacZ reporter gene. Genesis., v. 29, p. 1-13, 2001.

TIBBITS, T. T.; CASPAR, D. L. D.; PHILLIPS, W. C.; GOODENOUGH, D. A. Diffraction diagnosis of protein folding in gap junction connexons. Biophys. J., v. 57, p. $1025-1036,1990$.

TOMISAWA, M.; SUEMIZU, H.; OHNISHI, Y.; MARUYAMA, C.; URANO, K.; USUI, T.; YASUHARA, K.; TAMAOKI, N.; MITSUMORI, K. Mutation analysis of vinyl carbamate or urethane induced lung tumors in ras $\mathrm{H} 2$ transgenic mice. Toxicol. Lett., v. 142, n. 1-2, p. 111-117, 2003.

TOYOFUKU, T.; YABUKI, M.; OTSU, K.; KUZUYA, T.; HORI, M.; TADA, M. Direct association of the gap junction protein connexin43 with ZO-1 in cardiac myoytes. J. Biol. Chem., v. 273, p. 12725-12731, 1998.

TRAININ, N.; LINKER-ISRAELI, M.; SMALL, M.; BOITANO-CHEN, L. Enhancement of lung adenoma formation by neonatal thymectomy in mice treated with 7,12-dimethylbenz(a)anthracene or urethan. Int. J. Cancer., v. 15, p. 326-336, 1967.

TRAININ, N.; PRECERTTI, A.; LAW, L. W. Trends in carcinogenesis by urethane adminitered to newborn mice of different strains. Nature, v. 202, p. 305-306, 1964.

TRAUB, O. R.; ECKERT, H.; LICHTENBERG-FRATE, C.; ELFGANG, B.; BASTIDE, K. H.; SCHEIDTMANN, D. F.; HULSER, D. F.; WILLECKE, K. Immunochemical and electrophysiological characterization of murine connexin 40 and 43 in mouse tissues and transfected human cells. Eur. J. Cell Biol., v. 64, p. 101-112, 1994.

TRAUB, O. R.; LOOK, J.; DERMIETZEL, R.; BRUMMER, F.; HULSER, D.; WILLECKE, K. Comparative characterization of the 21-kDa and 26-kDa gap junction proteins in murine liver and cultured hepatocytes. J. Cell Biol., v. 108, p. 1039-1051, 1989.

TRAUB, O. R.; LOOK, J.; PAUL, D., WILLECKE, K. Cyclic adenosine monophosphate stimulates biosysnthesis and phosphorylation of the $26 \mathrm{kDa}$ gap junction protein in cultured mouse hepatocytes. Eur. J. Cell Biol., v. 43, p. 48-54, 1987. 
TROSKO, J. E.; RUCH, R. J. Cell-cell communication in carcinogenesis. Front. Biosciences, v. 3, p. d208-d236, 1998.

TU, Z. J.; KOLLANDER, R.; KIANG, D. T. Differential up-regulation of gap junction connexin 26 gene in mammary and uterine tissues: role of Sp transcription factors. Mol. Endocrinol., v. 12, p. 1931-1938, 1998.

TU, Z. J.; PAN, W.; GONG, Z.; KIANG, D. T. Involving AP-2 transcription factor in connexin 26up-regulation during pregnancy and lactation. Mol. Reprod.

Dev., v. 59, p. 17-24, 2001.

UNGER, V. M.; KUMAR, N. M.; GILULA, N. B.; YEAGER, M. Projection structure of a gap junction membrane channel at 7 A resulution. Nat. Struct. Biol., v. 4, p. 39-43, 1997.

UNGER, V. M.; KUMAR, N. M.; GILULA, N. B.; YEAGER, M. Threedemensional structure of a recombinant gap junction membrane channel. Science, v. 283, p. 1176-1180, 1999.

UNWIN, P. N. The structure of ion channels in membranes of excitable cells. Neuron., v. 3, p. 665-676, 1989.

UNWIN, P. N.; ZAMPIGHI, G. Structure of the junction between communicating cells. Nature, v. 283, p. 545-549, 1980.

VAIDYA, D.; TAMADDON, H. S.; LO, C. W.; TAFFET, S. M.; DELMAR, M.; MORLEY, G. E.; JALIFE, J. Null mutation of connexin43 causes slow propagation of ventricular activation in the late stages of mouse embryonic development. Circ. Res., v. 88, n. 11, p. 1196-1202, 2001.

VALIUNAS, V.; WEINGART, R.; BRINK, P. R. Formation of heterotypic gap junction channels byconnexins 40 and 43. Circ. Res. v. 86, p. E42-E49, 2000.

VAN RIJEN, H.; VAN KEMPEN, M. J.; ANALBERS, L. J.; ROOK, M. B.; VAN GINNEKEN, A. C.; GROS, D.; JONGSMA, H. J. Gap junctions in human umbilical cord endothelial cells contain multiple connexins. Am. J. Physiol., v. 272, n. 1, Pt 1, p. C117-C130, 1997.

VANSLYKE, J. K.; DESCHENES, S. M.; MUSIL, L. S. Intracellular transport, assembly, and degradtion of wild-type and disease-linked mutant gap junction proteins. Mol. Biol. Cell, v. 11, p. 1933-1946, 2000b.

VANSLYKE, J. K.; MUSIL, L. S. Analysis of connexin intracellular transsport and assembly. Methods, v. 20, p. 156-164, 2000a. 
VEENSTRA, R. D.; WANG, H. Z.; BEYER, E. C.; BRINK, P. R. Selective dye and ionic permeability of gap junction channels formed by connexin 45 . Circ. Res., v. 75, p. 483-490, 1994.

VOZZI, C.; ULLRICH, S.; CHAROLLAIS, A.; PHILIPPE, J.; ORCI, L.; MEDA, P. Adequate connexin-mediated coupling is required for proper insulin production. J. Cell Biol., v. 131, p. 1561-1572, 1995.

WAGNER, T. L. E.; BEYER, E. C.; MCMAHON, D. G. Cloning and functional expression of a novel gap junction channel from the retina of Danio aquipinnatus. Visual Neurosci. v. 15, p. 1137-1144, 1998.

WANG, X. G.; PERACCHIA, C. Connexin 32/38 chimeras suggest a role for the second half of inner loop in gap junction gating by low pH. Am. J. Physiol., v. 271, p. C1743-C1749, 1996.

WARD, J. M.; MAHLER, J. F.; MARONPOT, R. M.; SUNDBERG, J. P.; FREDERICKSON, R. M. Pathology of genetically engineered mice. lowa, EUA: lowa State University Press, 2000. 394 p.

WARD, J. M.; SINGH, G.; KATYAL, S. L.; ANDERSON, L. M.; KOVATCH, R. $M$ : Immunocytochemical localization of the surfactant apoprotein and clara cell antigen in chemically induced and naturally occuring pulmonary neoplasms of mice. Am. J. Path., v. 118, p. 493-499, 1985.

WARN-CRAMER, B. J.; COTTRELL, G. T.; BURT, J. M.; LAU, A. F. Regulation of connexin-43 gap junctional intercellular communication by mitogen-activated protein kinase. J. Biol. Chem., v. 273, p. 9188-9196, 1998.

WARN-CRAMER, B. J.; LAMPE, P. D.; KURATE, W. E.; KANEMITSU, M. Y.; LOO, L. W.; ECKHART, W.; LAU, A. F. Characterization of the mitogenactivated protein kinase phosphorylation sites on the connexn-43 gap junction protein. J. Biol. Chem., v. 271, p. C1743-C1749, 1996.

WHITE, T. W.; BRUZZONE, R.; GOODENOUGH, D. A.; PAUL, D. L. Mouse Cx50, a functional member of the connexin family of gap junction proteins, is the lens fiber protein MP70. Mol. Biol. Cell., v. 3, p. 711-720, 1992.

WHITE, T. W.; BRUZZONE, R.; GOODENOUGH, D. A.; PAUL, D. L. Voltage gating of connexins. Nature, v. 371, p. 208-209, 1994b.

WHITE, T. W.; BRUZZONE, R.; WOLFRAM, S.; PAUL, D. L.; GOODENOUGH, D. A. Selective interactions among the multiple connexin proteins expressed in the vertebrate lens: the second extracellular domain is a determinant of compatibility between connexins. J. Cell Biol., v. 125, p. 879-892, 1994a. 
WHITE, T. W.; GOODENOUGH, D. A.; PAUL, D. L. Ocular abnormalities in connexin 50 knockout mice. Mol. Biol. Cell., v. 8, p. 93, 1997.

WHITE, T. W.; GOODENOUGH, D. A.; PAUL, D. L.; BRUZZONE, R. Functional analysis of selective interactions among rodent connexins. Mol. Biol. Cell., v. 6, p. 459-470, 1995.

WHITE, T. W.; PAUL, D. L. Genetic diseases and gene knockouts reveal diverse connexin functions. Annu Rev. Physiol., v. 61, p. 283-310, 1999.

WHITE, T. W.; SELLITTO, C.; PAUL, D. L.; GOODENOUGH, D. A. Prenatal lens development in connexin43 and connexin50 double knockout mice. Invest. Ophthalmol. Vis. Sci., v. 42, n. 12, p. 2916-2923, 2001.

WILLECKE, K.; EIBERGER, J.; DEGEN, J.; ECKARDT, D.; ROMUALDI, A.; GULDENAGEL, M.; DEUTSCH, U.; SOHL, G. Structural and functional diversity of connexin genes in the mouse and human genome. Biol. Chem., v. 383, p. 725-737, 2002.

WILLECKE, K.; HENNEMANN, H.; DAHL, E.; JUNGBLUTH, S.; HEYNKES, R. The diversity of connexin genes encoding gap junctional proteins. Eur. J. Cell Biol., v. 56, p. 1-7, 1991a.

WILLECKE, K.; JUNGBLUTH, S.; DAHL, E.; HENNEMANN, H.; HEYNKES, R.; GRZESCHIK, K. H. Six genes of the human connexin gene family coding for gap junctional proteins are assigned to four different human chromosomes. Eur. J. Cell Biol., v. 53, p. 275-280, 1990.

WILLECKE, K.; TEMME A.; TEUBNER B., OTT, T. Characterization of targeted conexina 32-deficient mice: a model for the human Charcot-marie-Tooth (Xtype) inherited disease. Ann. N.Y. Acad. Sci., v. 883 p. 302-309, 1999.

WOODCOCK-MITCHELL, J.; MITCHELL, J. J.; REYNOLDS, S. E.; LESLIE, K. O.; LOW, R. B. Alveolar epithelial cell keratin expression during lung development. Am. J. Resp. Cell Mol. Biol., v. 2, p. 503-514, 1990.

YAMAKAGE, K.; OMORI, Y.; PICCOLI, C.; YAMASAKI, H. Growth control of 3T3 fibroblast cell line established from connexin 43-deficient mice. Mol.

Carcinog., v. 23, p. 121-128, 1998.

YAMAKAGE, K.; OMORI, Y.; ZAIDAN-DAGLI, M. L.; CROS, M. P.; YAMASAKI, $\mathrm{H}$. Induction of skin papillomas, carcinomas, and sarcomas in mice in which the connexin 43 gene is heterologously deleted. J. Invest. Dermatol., v. 114, n. 2, p. 289-294, 2000.

YAMASAKI, H. Gap junction intercellular communication and carcinogenesis.

Carcinogenesis, v. 11, n.7, p. 1051-1058, 1990. 
YAMASAKI, H.; KATOH, F. Novel method for selective killing of transformed rodent cells through intercellular communication, with possible therapeutic applications. Cancer Res., v. 48, p. 3203-3207, 1988.

YAMASAKI, H.; KRUTOVSKIKH, V.; MESNIL, M.; TANAKA, T.; DAGLI, M. L. Z.; OMORI, Y. Role of conexina (gap junction) genes in cell growth control and carcinogenesis. Comp. Ren. Acad. Sci. Paris, v. 322, p.151-159, 1999.

YAMASAKI, H.; MESNIL, M.; OMORI, Y.; MIRINOV, N.; KRUTOVSKIKH, V. Intercellular communication and carcinogenesis. Mutat. Res., v. 33, p. 181-188, 1995.

YAMASAKI, H.; NAUS, C. Role of connexin genes in growth control.

Carcinogenesis, v. 17, n. 6, p. 1199-1213, 1996.

YANG, D. I.; LOUIS, C. F. Molecular cloning of sheep connexin49 and its identity with MP70. Curr. Eye Res., v. 15, p. 307-314, 1996.

YEAGER, M.; NICHOLSON, B. J. Structure of gap junction intercellular channels. Curr. Opin. Struct. Biol., v. 6, p. 183-192, 1996.

YEAGER, M.; UNGER, V. M.; FALK, M. M. Synthesis, assembly, and structure of gap junction intercellular channels. Curr. Opin. Struct. Biol., v. 8, p. 517524, 1998.

YOON, B. I.; HIRABAYASHI, Y.; KAWASAKI, Y.; TSUBOI, I.; OTT, T.; KODAMA, Y.; KANNO, J.; KIM, D. Y.; WILLECKE, K.; INOUE, T. Exacerbation of benzene pneumotoxicity in connexin 32 knockout mice: enhanced proliferation of CYP2E1-immunoreactive alveolar epithelial cells. Toxicology, v. 195, p. 19-29, 2004.

YOSHIZAKI, G.; PATINO, R. Molecular clonig, tissue distribution, and hormonal control in the ovary of Cx41 mRNA, a novel xenopus connexin gene transcript. Mol. Reprod. Dev., v. 42, p. 7-18, 1995.

YU, W.; DAHL, G.; WERNER, R. The connexin 43 gene is responsive to oestrogen. Proc. R. Soc. Lond. B., v. 255, p. 125-132, 1994.

ZAMPIGHI, G.; UNWIN, P. N. Two forms of isolated gap junctions. J. Mol. Biol., v. 135, p. 451-464, 1979.

ZHANG, J. T.; NICHOLSON, B. J. Sequence and tissue distribution of a second protein of hepatic gap junctions, Gjb2, as deduced from its cDNA. J. Cell Biol., v. 109, p. 3391-3401, 1989. 
ZHANG, Y. W.; MORITA, I.; IKEDA, M.; MA, K. W.; MUROTA, S. Connexin43 suppresses proliferation of osteosarcoma U2OS cells through post-

transcriptional regulation of p27. Oncogene, v. 20, p. 4138-4149, 2001.

ZHANG, Z. Q.; ZHANG, W.; WANG, N. Q.; BANI-YAGHOUB, M.; LIN, Z. X.; NAUS, C. G. C. Suppresion of tumorigenicity of human lung carcinoma cells after transfection with connexin 43. Carcinogenesis, v. 19, n. 11, p. 1889-1894, 1998.

ZHAO, S.; FORT, A.; SPRAY, D. C. Characteristics of gap junction channels in Schwann cells from wild-type and connexin-null mice. Ann. N. Y. Acad. Sci., v. 883, p. 533-537, 1999.

ZHOU, X. W.; PFAHNL, A.; WERNER, R.; HUDDER, A.; LLANES, A.; LUEBKE, A.; DAHL, G. Identification of a pore lining segment in gap junction hemichannels. Biophys. J., v. 72, p. 1946-1953, 1997.

ZHU, D.; CAVENEY, S.; KIDDER, G. M.; NAUS, C. C. G. Transfection of C6 glioma cells with connexin 43 cDNA: analysis of expression, intercellular coupling, and cell proliferation. Proc. Nat. Acad. Sci. USA., v. 88, p.1883-1887, 1991.

ZHU, D.; KIDDER, G. M.; CAVENEY, S.; NAUS, C. C. Growth reatardation in glioma cells cocultured with cells overexpressing a gap junction protein. Proc. Natl. Acad. Sci. USA., v. 89, p. 10218-10221, 1992.

ZHU, W.; MIRONOV, N.; YAMASAKI, H. Increased genetic stability of HeLa cells after connexin 43 gene transfection. Cancer Res., v. 57, p. 2148-2150, 1997. 
APÊNDICE - A Representação esquemática do tipo de identificação utilizado na marcação dos camundongos

A

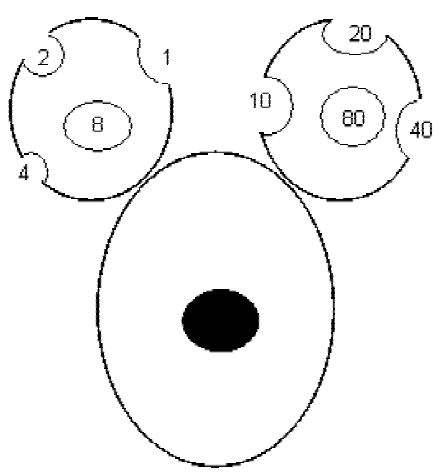

B

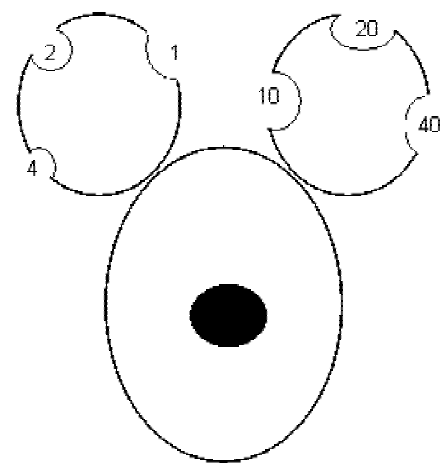

A. Na orelha direita de cada camundongo observa-se as unidades, enquanto que na orelha esquerda, são identificadas as dezenas. B. Exemplo da identificação do camundongo número 77. Para se chegar ao número de cada animal, soma-se todas as unidades mais todas as dezenas: Orelha direita: $1+2+4=7$; Orelha esquerda: $10+20+40=70 ; 7+70=77$ 